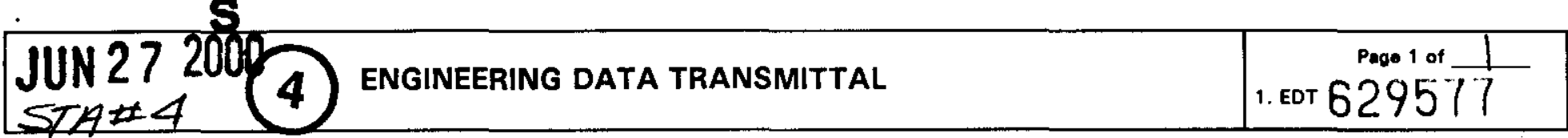

\begin{tabular}{|l|l|}
\hline $\begin{array}{l}\text { 2. To: (Recelving Organization) } \\
\text { Li censing }\end{array}$ & $\begin{array}{l}\text { 3. From: (Originating Organization) } \\
\text { Safety Analysis }\end{array}$ \\
\hline $\begin{array}{l}\text { 5. Proj./Prog./Dept./Div.: } \\
\text { Nuclear Safety \& Licensing }\end{array}$ & $\begin{array}{l}\text { 6. Design Authority/Design Agent/Cog. Engr.: } \\
\text { W. I. Cowley }\end{array}$ \\
\hline
\end{tabular}

8. Originator Remarks:

Approval and Release of Rev. 0 of Document

4. Related EDT No.:

N/A

7. Purchase Order No.

$\mathrm{N} / \mathrm{A}$

9. Equip./Component No.:

N/A

10. System/Bldg./Facility:

Tank Farms

12. Major Asem. Dwg. No.:

$\mathrm{N} / \mathrm{A}$

11. Receiver Remarks: 11A. Design Baseline Document? $O$ Yes $O$ No

13. Permit/Permit Application No.:

$\mathrm{N} / \mathrm{A}$

14. Required Response Date:

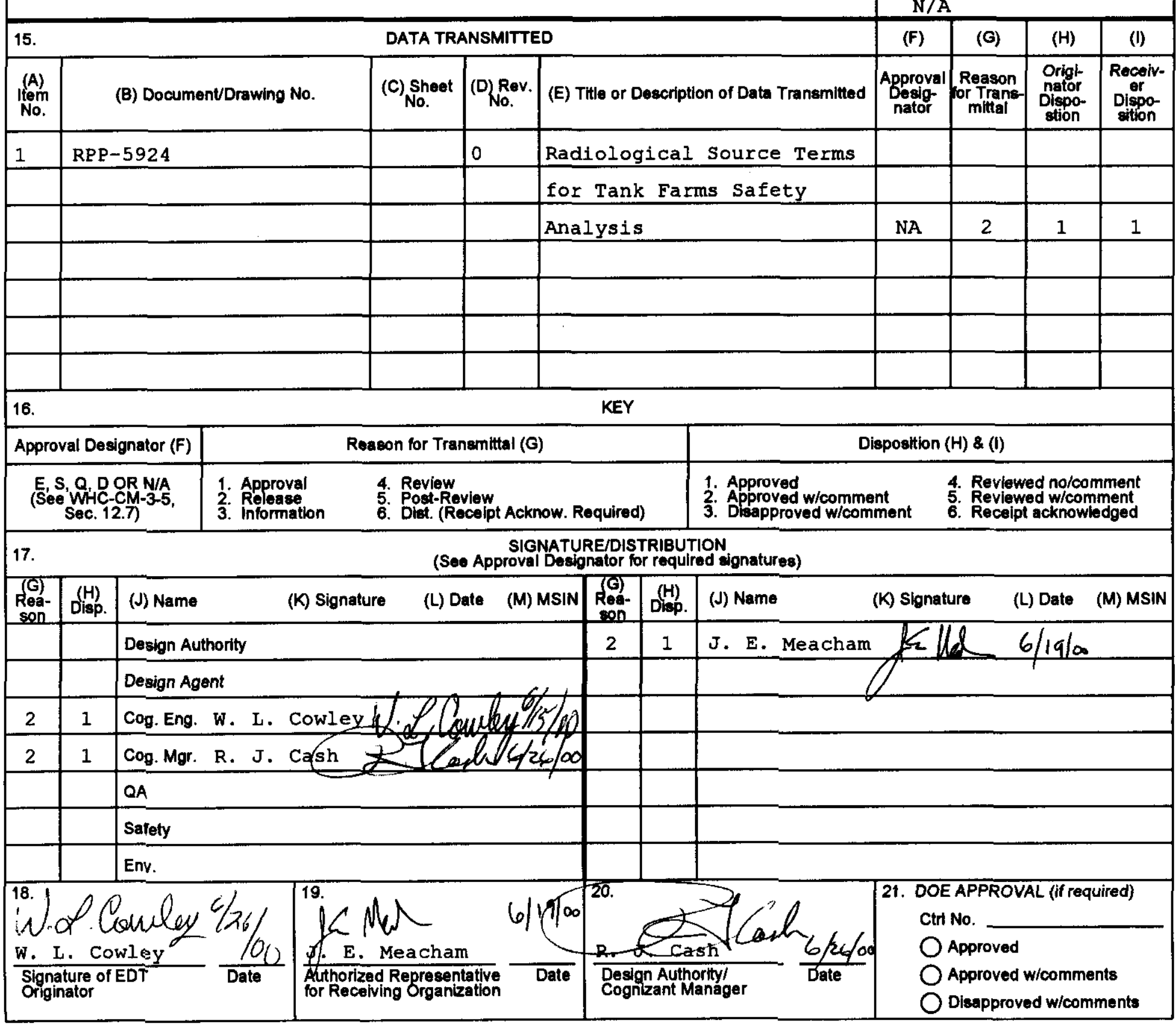




\title{
Radiological Source Terms for Tank Farms Safety Analysis
}

W. I. Cowley \& K. R. Sandgren, CH2M HILI Hanford Group, Inc.

J. C. Van Keuren, Fluor Federal Services

Richland, WA 99352

U.S. Department of Energy Contract DE-AC06-99RL14047

$\begin{array}{lll}\text { EDT/ECN: } & 629577 & \text { UC: N/A } \\ \text { Cost Center: } & 74 \text { F00 } & \text { Charge Code: } 101949 \\ \text { B\&R Code: } & \text { EW3120074 } & \text { Total Pages: } 208\end{array}$

Key Words: Unit Liter Dose, Tank Farm Dose Calculations, Radiological Dose Estimates, Atmospheric Dispersion Coefficients

\begin{abstract}
This document provides Unit Liter Dose factors, atmospheric dispersion coefficients, breathing rates and instructions for using and customizing these factors for use in calculating radiological doses for accident analyses in the Hanford Tank Farms.
\end{abstract}

TRADEMARK DISCLAIMER. Reference herein to any specific commercial product, process, or service by trade name, trademark, manufacturer, or otherwise, does not necessarily consthute or imply its endorsement, recommendation, or favoring by the United States Government or any agency thereof or its contractors or subcontractors.

Printed in the United States of America. To obtain copies of this document, contact: Document Control Services, P.O. Box 950, Mailstop H6-08, Richland WA 99352, Phone (509) 372-2420; Fax (509) 376-4989.

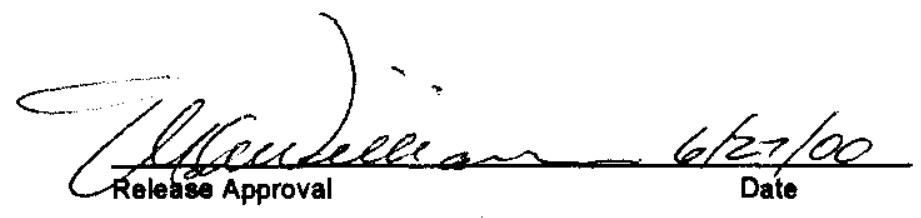

Approved For Public Release

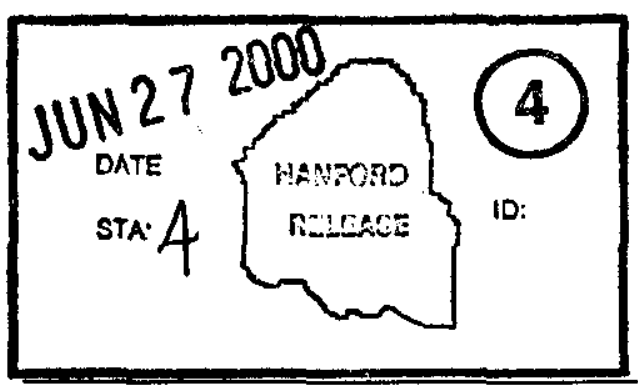

Release Stamp 


\section{RECORD OF REVISION}

\section{(1) Document Number}

RPP-5924

Page 1

(2) Title

Radiological Source Terms for Tank Farms Safety Analysis

Change Control Record

(3) Revision

(4) Description of Change - Replace, Add, and Delete Pages

RS 0
(7)

Release Rev. 0 of document on EDT 629577
Authorized for Release

(5) Cog. Eg.r. (6) Gog. Mgr. Date

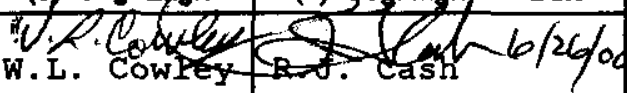

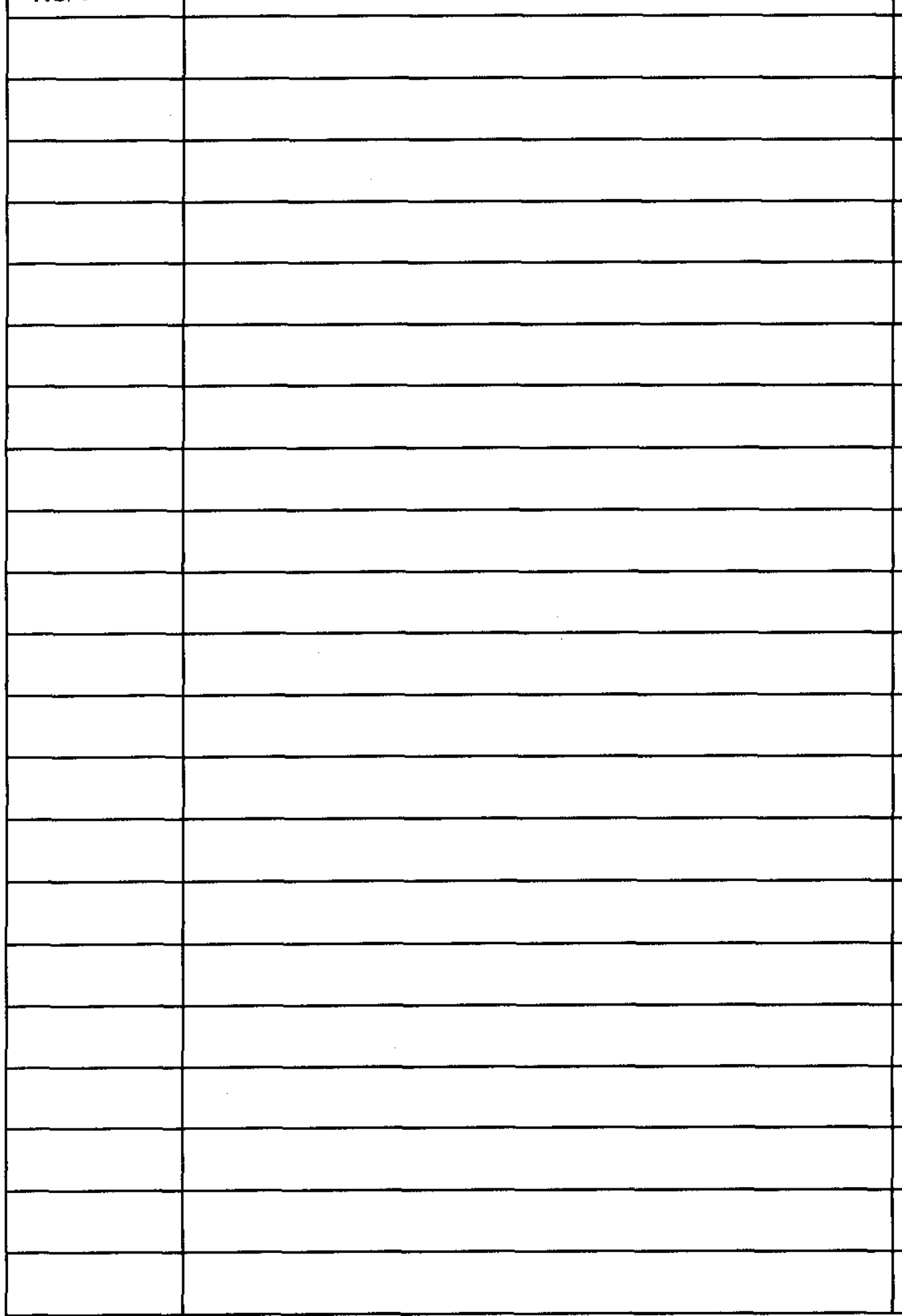


RPP-5924

Revision 0

\section{Radiological Source Terms for Tank Farm Safety Analysis}

W. L. Cowley

K. R. Sandgren

CH2M HILL Hanford Group, Inc.

J. C. Van Keuren

Fluor Federal Services

Date Published

June 2000

Prepared for the U.S. Department of Energy

Assistant Secretary for Environmental Management

\section{CH2MHILL \\ Hanford Group, Inc.}

P. O. Box 1500

Richland, Washington

Contractor for the U.S. Department of Energy

Office of River Protection under Contract DE-AC06-99RL14047

Approved for Public Release; Further Dissemination Unlimited 


\section{LEGAL DISCLAIMER}

This report was prepared as an account of work sponsored by an agency of the United States Government. Neither the United States Govemment nor any agency thereof, nor any of their employees, nor any of their contractors, subcontractors or their employees, makes any warranty, express or implied, or assumes any legal liability or responsibility for the

accuracy, completeness, or any third party's use or the results of such use of any information, apparatus, product, or process disclosed, or represents that its use would not infringe privately owned rights. Reference herein to any specific commercial product, process, or service by trade name, trademark, manufacturer, or otherwise, does not necessarily constitute or imply its endorsement, recommendation, or favoring by the United States Government or any agency thereof or its contractors or subcontractors. The views and opinions of authors expressed herein do not necessarily state or reflect those of the United States Government or any agency thereof.

This report has been reproduced from the best available copy. Available in paper copy and microfiche.

Available electronically at http://www.doe.gov/bridge. Available for a processing fee to the U.S. Department of Energy and its contractors, in paper, from:

U.S. Department of Energy Office of Scientific and Technical Information P.O. Box 62

Oak Ridge, TN 37831-0062

phone: 865-576-8401

fax: 865-576-5728

email: reports@adonis.osti.gov(423) 576-8401

Available for sale to the public, in paper, from:

U.S. Department of Commerce

National Technical Information Service

5285 Port Royal Road

Springfield, VA 22161

Phone: 800-553-6847

fax: 703-605-6900

email: orders@ ntis.fedworld.gov

online ordering:

http://www.ntis.gov/ordering.htm 
RPP-5924 REV 0

\section{EXECUTIVE SUMMARY}

This calculation note replaces both WHC-SD-WM-SARR-037, Development of Radiological Concentrations and Unit Liter Doses for TWRS FSAR Radiological Consequence Calculations, and WHC-SD-WM-SARR-016, Tank Waste Compositions and Atmospheric Dispersion Coefficients for Use in Safety Analysis Consequence Assessments. ${ }^{2}$ WHC-SD-WM-SARR-037 ${ }^{1}$ documented the selection of relevant radioisotopes, the development of radioisotope concentrations, and the calculation of unit liter doses for radiological consequence calculations used in HNF-SD-WM-SAR-067, Tank Waste Remediation System Final Safety Analysis Report. ${ }^{3}$ WHC-SD-WM-SARR-016 documented the meteorological considerations, atmospheric dispersion coefficients, and methodologies for calculating radiological doses and toxic chemical doses. All of the relevant information from both documents, plus new information, is included in this calculation note.

Unit liter doses are defined for four different waste types (single-shell tank solids and liquids, and double-shell tank solids and liquids) using statistical methods and current data from the Tank Characterization Database maintained by the Pacific Northwest National Laboratory. ${ }^{4}$ Within the waste types, unit liter doses are calculated for as many individual tanks as possible. The means are then distributed on a lognormal plot for each waste type. The 95 th percentile value for

\footnotetext{
${ }^{1}$ WHC-SD-WM-SARR-037, 1996, Development of Radiological Concentrations and Unit Liter Doses for TWRS FSAR Radiological Consequence Calculations, Rev. 0, Westinghouse Hanford Company, Richland, Washington.

${ }^{2}$ WHC-SD-WM-SARR-016, 1996, Tank Waste Compositions and Atmospheric Dispersion Coefficients for Use in Safety Analysis Consequence Assessments, Rev. 2, Fluor Daniel Northwest, Richland, Washington.

${ }^{3}$ HNF-SD-WM-SAR-067, 2000, Tank Waste Remediation System Final Safety Analysis Report, Rev. 1D, Lockheed Martin Hanford Corporation, Richland, Washington.
} 


\section{RPP-5924 REV 0}

each waste type is selected for use as the unit liter dose for radiological dose calculations for that waste type.

Use of the 95 th percentile from a distribution of means is a significant change from the former methodology, which selected a bounding unit liter dose for each waste type using a super-tank model for each waste type. The tank mean model does not attempt to bound all possible unit liter doses. Instead it provides a method of calculating unit liter doses based on selecting an appropriate risk level. The tank mean model also prevents individual statistically insignificant sample results from driving the process for determining unit liter doses.

This calculation note also includes changes in the assumed meteorology for calculating atmospheric dispersion coefficients, guidance on using plume buoyancy and plume depletion models, revised atmospheric dispersion coefficients, and revised dose conversion factors. The changes include directed actions and suggestions from TWRS-RT-SER-003, Safety Evaluation Report for the Tank Waste Remediation Systems (TWRS) Final Safety Analysis Report (FSAR), [HNF-SD-WM-SARR-067, Rev. H, September 1998], and Technical Safety Requirements, [HNF-SD-WM-TSR-006, Rev. F2, August 1997]. ${ }^{5}$

\footnotetext{
${ }^{4}$ PNNL, 1999, Tank Characterization Database, Version 3.28, available at http://twins.pnl.gov:8001/twins.htm, Pacific Northwest National Laboratory, Richland, Washington.

${ }^{5}$ TWRS-RT-SER-003, 1999, Safety Evaluation Report for the Tank Waste Remediation Systems (TWRS) Final Safety Analysis Report (FSAR), [HNF-SD-WM-SARR-067, Rev. H, September 1998], and Technical Safety Requirements, [HNF-SD-WM-TSR-006, Rev. F2, August 1997], Rev. 0, U.S. Department of Energy, Richland Operations Office, Richland, Washington.
} 


\section{CONTENTS}

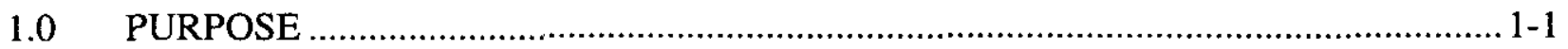

1.1 UNIT LITER DOSE DEVELOPMENT PROCESS .......................................1-1

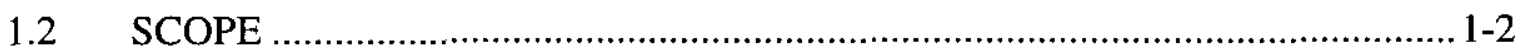

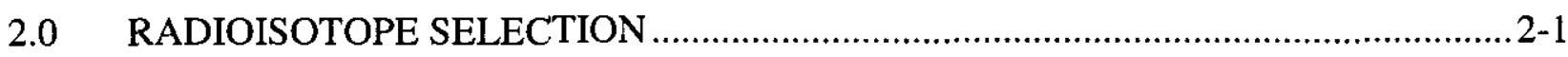

2.1 HISTORICAL BASIS FOR RADIONUCLIDE SELECTION ..........................2-1

2.2 RECALCULATING PERCENTAGE CONTRIBUTION OF ISOTOPES BASED ON CURRENT DOSE CONVERSION FACTORS ……......................2-5

2.3 REPRESENTATIVE RADIONUCLIDES SELECTED FOR

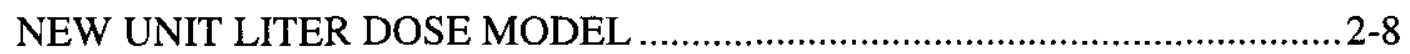

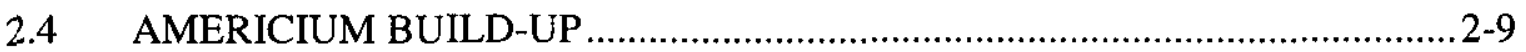

3.0 INTERNATIONAL COMMISSION ON RADIATION PROTECTION RECOMMENDED DOSE CONVERSION FACTORS ............................................. 3-1

3.1 INTRODUCTION............................................................................

3.2 DISCUSSION OF INTERNATIONAL COMMISSION ON RADIATION PROTECTION METHODS ............................................................................

3.3 ONSITE DOSE CONVERSION FACTORS ……....................................... 3-2

3.4 OFFSITE RECEPTOR DOSE CONVERSION FACTORS ……........................3-3

3.5 AVERAGE DOSE CONVERSION FACTORS FOR ALPHA

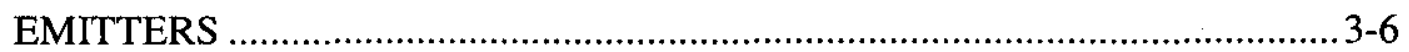

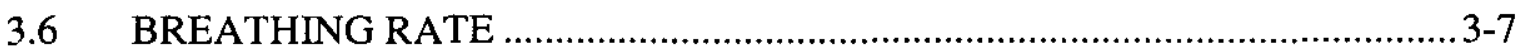

4.0 TANK CHARACTERIZATION DATA AND UNIT LITER DOSE MODELS ............4-1

4.1 ORIGINAL (SUPER-TANK) UNIT LITER DOSE MODEL ……....................4-2

4.2 MODEL USING STATISTICAL TREATMENT OF NEW CHARACTERIZATION DATA ……....................................................4-4

4.3 REPRESENTATIVENESS OF DATA SET …………............................... $4-15$

4.4 DEVELOPMENT OF UNIT LITER DOSES FOR SPECIAL CASES AND GROUPS OF TANKS ........................................................................4-18

5.0 ATMOSPHERIC DISPERSION COEFFICIENTS ................................................. $5-1$

$5.1 \quad$ DISCUSSION OF TERMS AND RESULTS ……........................................ 5-1

5.1.1 Atmospheric Dispersion Coefficient ......................................................5-1

5.1.2 Bounding Atmospheric Dispersion Coefficients.......................................5-2

5.1.3 Chronic Annual Average Meteorology ……….......................................5-4

5.1.4 Plume Meander ...............................................................................5-4

5.1.5 Puff Release Atmospheric Dispersion Coefficient for Toxicological

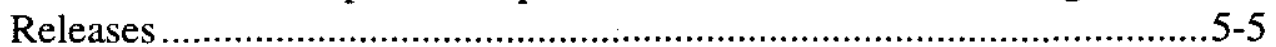

5.1.6 Other Models......................................................................................

5.2 SELECTION OF APPROPRIATE ATMOSPHERIC DISPERSION

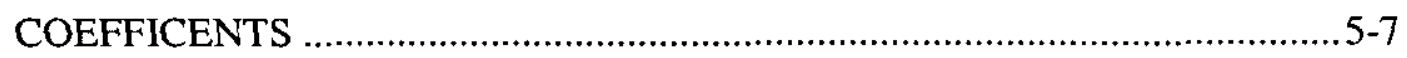

5.2.1 Release Duration Less than One Hour ..................................................5-7

5.2.2 Release Duration from One to Two Hours.............................................5-8 
5.2.3 Release Duration Greater than Two Hours ……......................................5-8

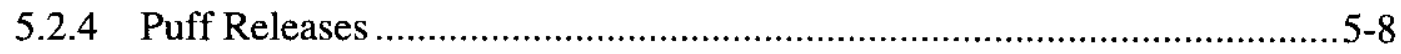

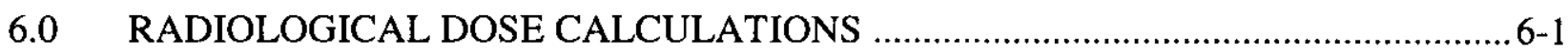

6.1 RADIOLOGICAL EXPOSURE PATHWAYS ............................................... 6-1

6.2 RADIOLOGICAL DOSE CALCULATION METHODS .................................. 6-3

7.0 DOSE RATE CALCULATION FOR HIGH-EFFICIENCY PARTICULATE AIR FILTERS ……………………............................................................

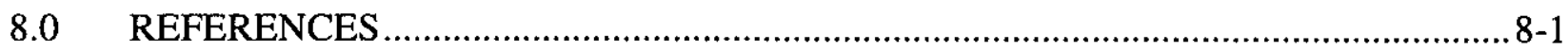

\section{APPENDIXES}

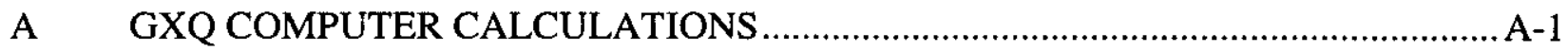

B CALCULATIONS TO SUPPORT THE SOURCE TERM USED IN THE RIVER PROTECTION PROJECT FINAL SAFETY ANALYSIS REPORT ................ B-1

C SAMPLE BASED UNIT LITER DOSE ESTIMATES ..............................................

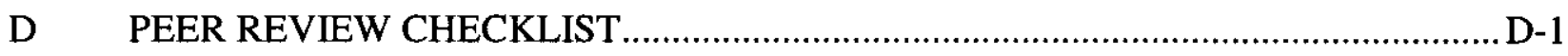




\section{LIST OF FIGURES}

Figure 2-1. Key Nuclides Starting With ORIGEN2 Isotope List of More than One Hundred Fifty Isotopes (Eleven Nuclides Account for More than Ninety-Nine Percent of Dose).

Figure 4-1. Unit Liter Dose Lognormal Density and Histogram for Single-Shell Tanks, Solid Samples, Using Dose Conversion Factors from ICRP-68.

Figure 4-2. Unit Liter Dose Lognormal Density and Histogram for Single-Shell Tanks, Liquid Samples, Using Dose Conversion Factors from ICRP-68.

Figure 4-3. Unit Liter Dose Lognormal Density and Histogram for Double-Shell Tanks, Solid Samples, Using Dose Conversion Factors from ICRP-68.

Figure 4-4. Unit Liter Dose Lognormal Density and Histogram for Double-Shell Tanks, Liquid Samples, Using Dose Conversion Factors from ICRP-68.

Figure 4-5. Unit Liter Dose Lognormal Density and Histogram for Single-Shell Tanks, Solid Samples, Using Dose Conversion Factors from ICRP-71.

Figure 4-6. Unit Liter Dose Lognormal Density and Histogram for Single-Shell Tanks, Liquid Samples, Using Dose Conversion Factors from ICRP-71.

Figure 4-7. Unit Liter Dose Lognormal Density and Histogram for Double-Shell Tanks, Solid Samples, Using Dose Conversion Factors from ICRP-71.

Figure 4-8. Unit Liter Dose Lognormal Density and Histogram for Double-Shell Tanks, Liquid Samples, Using Dose Conversion Factors from ICRP-71.

Figure 4-9. Single-Shell Tank Solid Alpha, $\mu \mathrm{Ci} / \mathrm{g}$. $4-16$

Figure 4-10. Single-Shell Tank Liquid Alpha, $\mu \mathrm{Ci} / \mathrm{g}$. 4-17 


\section{LIST OF TABLES}

Table 2-1. Percent Contribution from Selected Radionuclides Based on Total Activities......2-4

Table 2-2. Fraction of Unit Liter Doses from Strontium-90, Yttrium-90, Cesium-137 and Gross Alpha for Single-Shell Tank Solids and Liquids for Inhalation....................2-6

Table 2-3. Fraction of Unit Liter Dose from Strontium-90, Yttrium-90, Cesium-137 and Gross Alpha for Double-Shell Tank Solids and Liquids for Inhalation.

Table 2-4. Fraction of Unit Liter Dose from Strontium-90, Yttrium-90, Cesium-137 and Gross Alpha for Single-Shell and Double-Shell Tanks for Ingestion.

Table 2-5. Summary of Fraction from Strontium-90, Yttrium-90, Cesium-137 and Gross Alpha Percent Inhalation and Ingestion Doses.

Table 2-6. Americium-241 Activity as a Function of Time Based on Worst-Case Tank Data. $.2-9$

Table 2-7. Unit Liter Dose as a Function of Time for Single-Shell Tank Liquids. $2-11$

Table 2-8. Unit Liter Dose as a Function of Time for Single-Shell Tank Solids. 2-12

Table 3-1. Inhalation Dose Conversion Factors. 3-3

Table 3-2. Comparison of Dose Conversion Factor Times Breathing Rates for Receptors of Various Ages. 3-4

Table 3-3. Dose Conversion Factors for Offsite Receptors.

Table 3-4. Effective Dose Conversion Factors for Alpha-Emitters for Different Composites Based on Dose Conversion Factors from ICRP-68 and ICRP-71 ......3-8

Table 4-1. Inhalation Unit Liter Doses for Onsite Receptor, 95th Percentile..........................4-1

Table 4-2. Total Unit Liter Dose for Accident Analysis for the Public, 95th Percentile.........4-1

Table 4-3. Inhalation and Ingestion Unit Liter Doses for Tank 241-AZ-101 Accident Analyses.

Table 4-4. Bounding Concentrations. ..............................................................................

Table 4-5. Comparison of Bounding Concentrations...............................................................4-4

Table 4-6. Summary of Unit Liter Doses by Percentile and Tolerance Limit. ..........................4-6

Table 4-7. Comparison of Means and Variances of Unit Liter Doses by Waste Type for the Three Models (M1, M2, and M3) for Detection Limits. 


\section{RPP-5924 REV 0}

Table 5-1. Site Boundary Distances.............................................................................. 5-3

Table 5-2. Acute Centerline Dispersion Coefficients for 200 Area Tank Farm to Onsite Receptor at One Hundred Meters.

Table 5-3. Acute Centerline Dispersion Coefficients for 200 Area Tank Farm Release to Offsite Receptor in 45-Degree Sectors.............................................................5-4

Table 5-4. Effects of Plume Depletion............................................................................. 5-6

Table 5-5. Effects of Source Width on Receptor Dose......................................................... 5-7

Table 7-1. Ninety-Fifth and Ninety-Ninth Percentile Points from the Lognormal Distribution for Cesium-137............................................................................. 7-2 


\section{LIST OF TERMS}

\begin{tabular}{ll} 
AMAD & activity median aerodynamic diameter \\
ARF & airborne release fraction \\
AWF & Aging Waste Facility \\
Bq/L & bequerels per liter \\
CHG & CH2M HILL Hanford Group, Inc. \\
DCF & dose conversion factor \\
DCRT & double-contained receiver tank \\
DOE & U.S. Department of Energy \\
DST & double-shell tank \\
FSAR & final safety analysis report \\
HEPA & high-efficiency particulate air (filter) \\
ICRP & International Commission on Radiation Protection \\
LMHC & Lockheed Martin Hanford Corporation \\
MAR & material at risk \\
NRC & U.S. Nuclear Regulatory Commission \\
RF & respirable fraction \\
RL & U.S. Department of Energy, Richland Operations Office \\
RPP & River Protection Project \\
SST & single-shell tank \\
SV/Bq & Sieverts per Bequerel \\
Sv/L & Sieverts per Liter \\
TCD & Tank Characterization Database \\
TWRS & Tank Waste Remediation System \\
ULD & unit liter dose \\
\hline
\end{tabular}


RPP-5924 REV 0

\section{RADIOLOGICAL SOURCE TERMS FOR TANK FARM SAFETY ANALYSIS}

\subsection{PURPOSE}

This report serves the dual purposes of conducting an annual update of the radiological source term used in the River Protection Project (RPP) Final Safety Analysis Report (FSAR), HNF-SD-WM-SAR-067, Tank Waste Remediation System Final Safety Analysis Report, and of addressing concerns that the current source term is overly conservative and may result in inflation of calculated consequences. The goals of this report are as follows:

- Ensure that the source term is not driving unnecessary controls and restrictions

- Maintain a unit liter dose (ULD) selection process that is logical and defendable

- Develop a process that is flexible enough to serve future retrieval projects, based on the current level of knowledge about retrieval

- Incorporate recent improvements in both consequence assessment and waste tank data.

The Characterization Program has taken many core samples in the last 4 years. The laboratories have analyzed the samples, and a large volume of new sample data is available for use in updating the ULDs used in the FSAR (HNF-SD-WM-SAR-067). A working group was convened to evaluate the impact of the new data on the source terms and to recommend an approach or criteria for updating the source terms. The group included personnel from the Nuclear Safety and Licensing and the Process Engineering organizations at CH2M HILL Hanford Group, Inc. (CHG).

Since the publication of HNF-SD-WM-SAR-067, the Tank Waste Remediation System (TWRS) has become the RPP. In the balance of this document, RPP will be used rather than TWRS, except in references where TWRS is used. Lockheed Martin Hanford Corporation (LMHC) became $\mathrm{CHG}$ while this report was being prepared. In the balance of this document, $\mathrm{CHG}$ will be used rather than LMHC, except in references where LMHC is used.

\subsection{UNIT LITER DOSE DEVELOPMENT PROCESS}

This analysis develops ULDs for use in the RPP FSAR. The ULD is the inhalation or ingestion dose obtained when an individual inhales (or ingests) one liter of waste. The ULDs provide a practical way to calculate radiological dose consequences for a variety of potential accidents. Safety analysis relies on consequence analysis to calculate the radiation dose to defined receptors onsite and offsite. These analyses need a 'source term' to calculate the dose. The source term is a quantity of specified hazardous material. The material specification must include quantity, physical form, and specific properties of the hazardous material. For radiation hazards, this 
includes specifying the particle sizes, quantity in kilograms per volume of air, radioactive isotopes present, and concentrations of the isotopes. The ULD provides the information for radioactive isotopes present and their concentrations in one liter of tank waste and quantifies this information as radiological dose in Sieverts per Liter (Sv/L) of tank waste.

The ULDs are used in consequence calculations based on acute inhalation dose and direct radiation dose to facility workers and acute ingestion dose and ground shine for offsite receptors during the first 24-hour period following a release. After the first 24 hours, it is assumed that people offsite have been evacuated and any contaminated food and water has been interdicted. Chronic consequences are not included in the FSAR calculations (HNF-SD-WM-SAR-067).

The first step in developing ULDs is to define the radioisotopes that need to be included. The selection of the radioisotopes is described in Chapter 2.0 of this report. An explanation of dose conversion factors (DCFs) is included in Chapter 3.0. The statistical development of the ULDs is presented in Chapter 4.0. Chapter 5.0 discusses atmospheric dispersion, and Chapter 6.0 presents methods for radioactive dose calculations. Chapter 7.0 describes dose rate calculations for high-efficiency particulate air (HEPA) filters.

\subsection{SCOPE}

The ULDs in this analysis apply to the following facilities and projects:

- Single-shell tanks (SSTs)

- Double-shell tanks (DSTs)

- $\quad$ Aging Waste Facility (AWF) tanks

- Catch tanks, valve pits, diversion boxes, and clean-out boxes

- Double-contained receiver tanks (DCRTs)

- Waste retrieval (within the limits of current project assumptions).

In WHC-SD-WM-SARR-016, Tank Waste Compositions and Atmospheric Dispersion Coefficients for Use in Safety Analysis Consequence Assessments, tanks 241-AY-101, 241-AY-102, 241-AZ-101, and 241-AZ-102 were designated as AWF tanks. In this report, tanks 241-AY-101, 241-AY-102, and 241-AZ-102 are designated DSTs and are included in the DST ULDs. This change was made on the basis of new sample data. Samples have been taken from these tanks during the last 5 years as part of the Tank Characterization Program. Mean ULDs have been calculated for each of these tanks using the sample data. The mean ULDs are within the range of mean ULDs developed for the DSTs. Therefore, these tanks are grouped with the DSTs.

Tank 241-AZ-101 is still designated as an AWF tank because analysis results of recent samples taken from tank 241-AZ-101 are not complete. Tank 241-AZ-101 may be reclassified when the samples have been analyzed. Until then, 241-AZ-101 is still considered to be an AWF tank. 
RPP-5924 REV 0

\subsection{RADIOISOTOPE SELECTION}

Although many radionuclides can be detected in Hanford Site waste, the number of radionuclides that are significant for acute radiological dose calculations is limited. Section 2.1 describes the initial process by which the minimum number of radionuclides necessary to calculate inhalation, ingestion, and shine doses was determined for use in WHC-SD-WM-SARR-016. The list of possible radionuclides was narrowed from approximately 150 to 22 in WHC-SD-WM-SARR-016. Section 2.2 describes how the list from WHC-SD-WM-SARR-016 has been narrowed in this document to 3 analytes.

\subsection{HISTORICAL BASIS FOR RADIONUCLIDE SELECTION}

The steps used in WHC-SD-WM-SARR-016 to select the nuclides important to dose is illustrated in Figure 2-1. The process selectively reduced the total number of radionuclides to 11 . The process started with evaluation of more than 150 nuclides tracked by the ORIGEN2 computer code (ORNL-5621). The criterion used in the initial analysis of the ORIGEN2 data was to select all the radionuclides that contributed 0.1 percent or more to inhalation dose. This resulted in a list of 22 radionuclides. The requirement for including 24-hour ingestion and ground shine for offsite receptors was introduced after the initial list of 22 radionuclides was selected. After review, it was determined that the list of 22 radionuclides included the radionuclides required for calculating the ingestion and ground shine doses. For the analyses in the FSAR (HNF-SD-WM-SAR-067), the group was reduced to the 11 radionuclides that accounted for $99+$ percent of the total (inhalation, shine, and 24-hour ingestion) radiological dose: ${ }^{60} \mathrm{Co},{ }^{90} \mathrm{Sr},{ }^{90} \mathrm{Y},{ }^{137} \mathrm{Cs},{ }^{154} \mathrm{Eu},{ }^{237} \mathrm{~Np},{ }^{238} \mathrm{Pu},{ }^{239 / 240} \mathrm{Pu},{ }^{241} \mathrm{Pu},{ }^{241} \mathrm{Am}$, and ${ }^{244} \mathrm{Cm}$.

WHC-SD-WM-SARR-016, which contains most of the calculations referenced in this section, uses the list of 22 radionuclides for performing calculations. Because WHC-SD-WM-SARR-016 is frequently quoted in this report, some confusion may be caused by switching between 22 radionuclides and 11 radionuclides. Where relevant, this report notes whether the 22 or 11 radionuclides are used. The difference in total radiological dose is less than 1 percent between calculations made using the 11 isotopes and those made using the 22 isotopes.

The radionuclides selected for use in the dose calculations in WHC-SD-WM-SARR-016 are not equally significant for each of the tank waste models. For some of the ULDs, five radionuclides ${ }^{9} \mathrm{Sr},{ }^{90} \mathrm{Y},{ }^{137} \mathrm{Cs},{ }^{239} \mathrm{Pu}$, and $\left.{ }^{241} \mathrm{Am}\right)$ make up about 95 percent of the total dose. However, for consistency, the same 11 radionuclides were used for each tank model.

Several waste transfer accident scenarios result in spills of radioactive material to the ground. These spills are a source of concentrated radioactivity and result in a direct external dose to workers. The dominant contributors to the direct external dose $\left({ }^{90} \mathrm{Sr},{ }^{90} \mathrm{Y}\right.$, and $\left.{ }^{137} \mathrm{Cs}\right)$ are included in the 11 radionuclides because of their high contribution to inhalation dose. Two of the 11 radionuclides $\left({ }^{60} \mathrm{Co}\right.$ and $\left.{ }^{154} \mathrm{Eu}\right)$ were selected because of their contribution to the direct external dose although their contribution to the inhalation dose is less than 1 percent. The process used to identify the key dose contributors is described below. 
Figure 2-1. Key Nuclides Starting With ORIGEN2 Isotope List of More than One Hundred Fifty Isotopes (Eleven Nuclides Account for More than Ninety-Nine Percent of Dose).

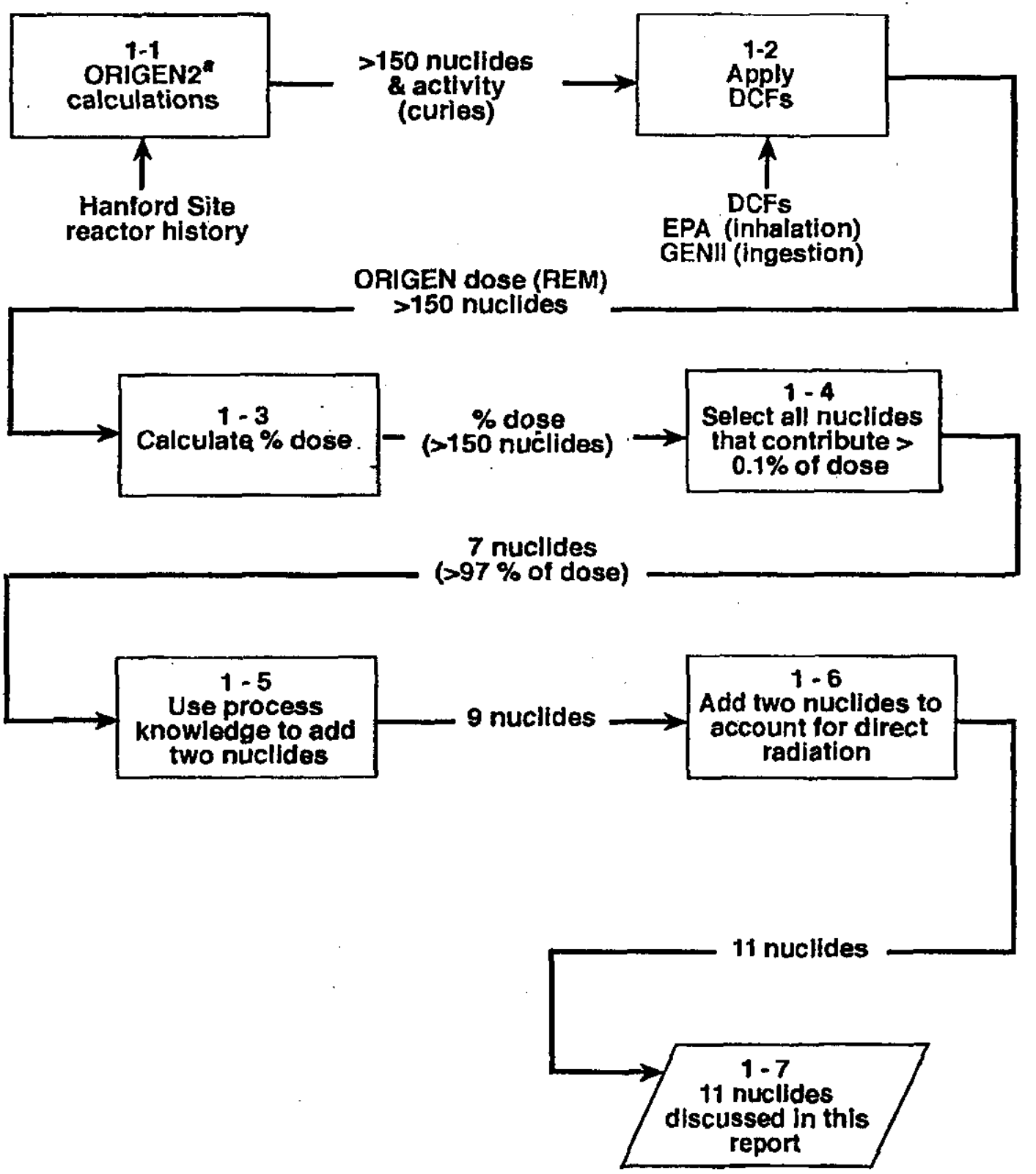

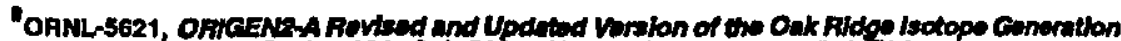
and Deplution Cod 1080, Otik Fidge National Labortory, Oak Aldge, Tennessee. 
The ORIGEN2 computer code (ORNL-5621) was used to estimate the inventory of radioactive materials contained in the fuel from the single-pass reactors and $\mathrm{N}$ Reactor, as reported in WHC-SD-WM-RPT-164, Inventories for Low-Level Waste Tank Waste (see Figure 2-1, block 1-1). Total radionuclide inventories were calculated based on the complete operating history of all of the Hanford Site production reactors. Reduction factors were then applied to the total inventories to account for plutonium and uranium extracted from the waste sent to the tanks. Reduction factors also were applied to other isotopes, including cesium and strontium, which were extracted from some of the waste. A separate ORIGEN2 run was made to decay the radioactive inventory in WHC-SD-WM-RPT-164 to the end of 1994 so that a comparison could be made with the values in WHC-SD-WM-ER-400, Tank Waste Source Term Inventory Validation, which also were decayed to the end of 1994.

The ORIGEN2 computer code (ORNL-5621) estimates activity inventories for three different groups: actinides, fission products, and activation products. The total estimated activity for each radionuclide from ORIGEN2 was multiplied by the inhalation DCF to determine the inhalation dose hazard for that radionuclide. The DCFs were taken from EPA-520/1-88-020, Federal Guidance Report No. 11, Limiting Values of Radionuclide Intake and Air Concentration and Dose Conversion Factors for Inhalation, Submersion, and Ingestion, and represented the committed effective dose equivalent in units of Sieverts per Bequerel (Sv/Bq) for a 50-year dose commitment period. The DCFs reported in EPA-520/1-88-020 were taken from ICRP-26, Recommendations of the International Commission on Radiological Protection.

ORIGEN2 computer code (ORNL-5621) calculations identified seven radioisotopes that contributed approximately 99 percent of the inhalation dose. Safety analysts added two radionuclides $\left({ }^{237} \mathrm{~Np}\right.$ and ${ }^{244} \mathrm{Cm}$ ) because of uncertainty about the total quantity of these radionuclides and two additional radionuclides $\left({ }^{60} \mathrm{Co}\right.$ and $\left.{ }^{154} \mathrm{Eu}\right)$ to account for direct radiation.

The 11 radionuclides were then ranked by inhalation dose hazard as shown in Table 2-1 and Figure 2-1, block 1-2. The 11 radionuclides listed in Table 2-1 make up 99+ percent of the total dose calculated by the ORIGEN2 computer code (ORNL-5621). The ULDs calculated in WHC-SD-WM-SARR-016 use an additional 11 radionuclides for a total of 22 radionuclides. Because the second group of 11 radionuclides collectively added less than 1 percent to the total ULD, they are not included in Table 2-1. The DCFs in Table 2-1 are taken directly from ICRP-26. 
Table 2-1. Percent Contribution from Selected Radionuclides Based on Total Activities.

\begin{tabular}{|c|c|c|c|c|}
\hline Nuclide & $\begin{array}{l}\text { ORIGEN2 }^{a} \\
\text { Total Activity } \\
\text { (Ci) }\end{array}$ & $\begin{array}{c}\text { ICRP-26 DCF } \\
(\mathrm{rem} / \mathrm{Ci})\end{array}$ & $\begin{array}{c}\text { ORIGEN2 }{ }^{\mathrm{a}} \\
\text { Dose } \\
\text { (rem) }\end{array}$ & $\begin{array}{c}\text { ORIGEN2 }^{\mathrm{a}} \\
\text { Percent Total Dose }\end{array}$ \\
\hline${ }^{61)} \mathrm{Co}$ & $9.24 \mathrm{E}+03$ & $2.19 \mathrm{E}+05$ & $2.02 \mathrm{E}+09$ & 0.0 \\
\hline${ }^{90} \mathrm{Sr}$ & $8.64 \mathrm{E}+07$ & $2.39 \mathrm{E}+05$ & $2.06 \mathrm{E}+13$ & 30.3 \\
\hline${ }^{i(1)} \mathrm{Y}$ & $8.64 \mathrm{E}+07$ & $8.44 \mathrm{E}+03$ & $7.29 \mathrm{E}+11$ & 1.1 \\
\hline${ }^{137} \mathrm{Cs}$ & $7.16 \mathrm{E}+07$ & $3.19 \mathrm{E}+04$ & $2.28 \mathrm{E}+12$ & 3.4 \\
\hline${ }^{1.54} \mathrm{Eu}$ & $2.32 \mathrm{E}+05$ & $2.86 \mathrm{E}+05$ & $6.64 \mathrm{E}+10$ & 0.1 \\
\hline${ }^{237} \mathrm{~Np}$ & $7.45 \mathrm{E}+01$ & $5.40 \mathrm{E}+08$ & $4.02 \mathrm{E}+10$ & 0.1 \\
\hline${ }^{238} \mathrm{Pu}$ & $2.52 \mathrm{E}+03$ & $3.92 \mathrm{E}+08$ & $9.88 \mathrm{E}+11$ & 1.5 \\
\hline${ }^{2319} \mathrm{Pu}$ & $4.43 E+04$ & $4.29 \mathrm{E}+08$ & $1.90 \mathrm{E}+13$ & 27.9 \\
\hline${ }^{24]} \mathrm{Pu}$ & $1.48 \mathrm{E}+05$ & $8.25 \mathrm{E}+06$ & $1.22 \mathrm{E}+12$ & 1.8 \\
\hline${ }^{241} \mathrm{Am}$ & $5.18 \mathrm{E}+04$ & $4.44 \mathrm{E}+08$ & $2.30 \mathrm{E}+13$ & 33.8 \\
\hline${ }^{244} \mathrm{Cm}$ & $4.04 \mathrm{E}+02$ & $2.48 \mathrm{E}+08$ & $1.00 \mathrm{E}+11$ & 0.1 \\
\hline Total & & & $6.48 \mathrm{E}+13$ & $\begin{array}{c}100.1 \text { rounded to } \\
100 \%\end{array}$ \\
\hline
\end{tabular}

"ORNL-5621, 1980, OR/GEN2-A Revised and Updated V'rsion of the Oak Ridge' lsotope Generation and Depletion Code, Oak Ridge National I aboratory, Oak Ridge, Tennessee.

'ICRP-26, 1977, Recommendations of the International Commission of Radiological Protection. Annals of the International Commission on Radiation Protection, Volume 1, Number 3, Elsevier Science, Tarrytown, New York.

DCF -... dose conversion factor. 


\subsection{RECALCULATING PERCENTAGE CONTRIBUTION OF ISOTOPES BASED ON CURRENT DOSE CONVERSION FACTORS}

Using the same process described above, the percentage of the total dose attributable to each of the 11 radionuclides listed in Table 2-1 was recalculated using updated DCFs. The calculations for inhalation dose are documented in the attachment to Letter CO-00-RPP-270, Deliverable for Contract 4976, Release 8, Updated Dose Methods (L-03) (Brevick 2000), and the results are summarized in Tables 2-2 and 2-3. Tables 2-2 and 2-3 use units of Sv/Bq for the DCF, bequerels per liter $(\mathrm{Bq} / \mathrm{L})$ for activity, and $\mathrm{Sv} / \mathrm{L}$ for the ULD. WHC-SD-WM-SARR-016 used DCFs based on guidance in EPA-520/1-88-020. The EPA report used information for DCFs taken from ICRP-26 and ICRP-30, Limits for Intakes of Radionuclides by Workers. This calculation note uses newer information from ICRP-68, Dose Coefficients for Intakes of Radionuclides by Workers-Replacement of ICRP Publication 61; ICRP-71, Age Dependent Doses to Members of the Public from Intake of Radionuclides Part 4 Inhalation Dose Coefficients; and ICRP-72, Age Dependent Doses to Members of the Public from Intake of Radionuclides Part 5 Compilation of Ingestion and Inhalation Dose Coefficients. ICRP-68 is for onsite workers, and ICRP-71 and ICRP-72 are for the offsite public. The International Commission on Radiation Protection (ICRP) publications are described in Chapter 3.0 of this report.

Tables 2-2 and 2-3 differ from Table 2-1 in that Table 2-1 considers all of the waste as a single quantity with no distinction between phases or among the processes it has been through.

Tables 2-2 and 2-3 make distinctions between liquids and solids, and among the types of tanks (SSTs, DSTs, and AWF) in which the waste is stored. Tables 2-2 and 2-3 use DCFs taken from ICRP-71 and ICRP-72. Percentages would be similar for DCFs taken from ICRP-68.

The contributions to ingestion dose are calculated in a similar manner and are summarized in Table 2-4. Ingestion doses for individual isotopes are taken from WHC-SD-WM-SARR-016, which used the GENII computer program (PNL-6584) to calculate the ingestion doses. The first group in Table 2-4 includes the isotopes ${ }^{90} \mathrm{Sr},{ }^{90} \mathrm{Y},{ }^{137} \mathrm{Cs}$, and alpha emitters selected for use in this document. Isotopes listed under "Other" are the isotopes not included in this group. The original calculations in WHC-SD-WM-SAR-016 included the 11 tracked isotopes plus the 11 additional isotopes. Only the 11 tracked isotopes are included in this calculation because the contribution of the other isotopes is negligible. "Fraction" is the total of the doses from the 8 selected isotopes divided by the total dose from all 11 isotopes. The ingestion DCFs are based on ICRP-26 and ICRP-30. GENII has not been updated to include newer information (PNL-6584). The ingestion dose is a small percentage ( 0.3 to 6 percent) of total dose, and the differences between ingestion doses using DCFs from ICRP-26, ICRP-30, and ICRP-71 would be very small. Therefore the use of ICRP-26 and ICRP-30 for ranking of ingestion doses will not adversely affect either the total dose calculation or conservatism.

The purpose of recalculating the fractions based on sample data is two-fold.

- By separating the waste by phase and tank category, the contribution of each isotope to the total dose is more accurately described for each waste type.

- Sample data are not available for all of the radionuclides. By identifying the key radionuclides, existing sample data for a subset of the larger group may be used to calculate dose. 
Table 2-2. Fraction of Unit Liter Doses from Strontium-90, Yttrium-90, Cesium-137 and Gross Alpha for Single-Shell Tank Solids and Liquids for Inhalation.

\begin{tabular}{|c|c|c|c|c|c|}
\hline Isotope & $\begin{array}{c}\text { ICRP-71 and } \\
\text { ICRP-72* } \\
\text { DCF } \\
\text { (Sv/Bq) }\end{array}$ & $\begin{array}{c}\text { SST Liquids } \\
\text { Activity } \\
\text { (Bq/L) }\end{array}$ & $\begin{array}{c}\text { SST Liquids } \\
\text { ULD } \\
(\mathrm{Sv} / \mathrm{L})\end{array}$ & $\begin{array}{c}\text { SST Solids } \\
\text { Activity } \\
\text { (Bq/L) }\end{array}$ & $\begin{array}{c}\text { SST Solids } \\
\text { ULD } \\
\text { (Sv/L) }\end{array}$ \\
\hline${ }^{60} \mathrm{Co}$ & $1.00 \mathrm{E}-08$ & $9.53 \mathrm{E}+06$ & 9.53 E-02 & $4.18 \mathrm{E}+08$ & $4.18 \mathrm{E}-00$ \\
\hline${ }^{90} \mathrm{Sr}$ & $3.60 \mathrm{E}-08$ & $1.05 \mathrm{E}+10$ & $3.78 E+02$ & $1.63 E+12$ & $5.87 E+(04$ \\
\hline${ }^{90} \mathrm{Y}$ & $1.50 \mathrm{E}-09$ & $1.05 \mathrm{E}+10$ & $1.58 \mathrm{E}+01$ & $1.63 E+12$ & $2.45 \mathrm{E}+03$ \\
\hline${ }^{137} \mathrm{Cs}$ & $4.60 \mathrm{E}-(09$ & $2.21 \mathrm{E}+10$ & $1.02 \mathrm{E}+02$ & $1.01 \mathrm{E}+11$ & $4.65 \mathrm{E}+02$ \\
\hline${ }^{154} \mathrm{Eu}$ & $5.30 \mathrm{E}-08$ & $2.35 E+09$ & $1.25 \mathrm{E}+02$ & $5.75 \mathrm{E}+09$ & $3.05 \mathrm{E}+02$ \\
\hline${ }^{237} \mathrm{~Np}$ & $2.30 \mathrm{E}-05$ & $0.00 \mathrm{E}+01$ & $0.00 \mathrm{E}+01$ & $3.02 \mathrm{E}+07$ & $6.95 \mathrm{E}+02$ \\
\hline${ }^{238} \mathrm{Pu}$ & $4.60 \mathrm{E}-05$ & $9.21 E+04$ & $4.24 \mathrm{E}-00$ & $1.87 E+08$ & 8.60 $\mathrm{E}+03$ \\
\hline${ }^{239} \mathrm{Pu}$ & $5.00 \mathrm{E}-05$ & $3.62 \mathrm{E}+07$ & $1.81 \mathrm{E}+03$ & $4.40 \mathrm{E}+08$ & $2.20 \mathrm{E}+04$ \\
\hline${ }^{241} \mathrm{Pu}$ & $9.00 \mathrm{E}-07$ & $2.57 \mathrm{E}+08$ & $2.31 \mathrm{E}+02$ & $3.22 \mathrm{E}+09$ & $2.90 \mathrm{E}+03$ \\
\hline${ }^{241} \mathrm{Am}$ & $4.20 \mathrm{E}-05$ & $4.23 E+07$ & $1.78 E+03$ & $2.29 \mathrm{E}+08$ & $9.62 E+03$ \\
\hline${ }^{244} \mathrm{Cm}$ & 2.70 E-05 & $4.23 E+05$ & $1.14 \mathrm{E}+01$ & $2.29 \mathrm{E}+06$ & $6.18 \mathrm{E}+01$ \\
\hline Total UID & & & $4.45 E+03$ & & $1.06 \mathrm{E}+05$ \\
\hline \multicolumn{3}{|c|}{${ }^{90} \mathrm{Sr}+{ }^{90} \mathrm{Y}+{ }^{137} \mathrm{Cs}+$ alpha } & $4.10 \mathrm{E}+03$ & & $1.03 \mathrm{E}+05$ \\
\hline \multicolumn{3}{|c|}{${ }^{90} \mathrm{Sr}+{ }^{90} \mathrm{Y}+{ }^{1.37} \mathrm{Cs}+$ alpha/Total ULD } & 0.92 & & 0.97 \\
\hline
\end{tabular}

*ICRP-71, 1995, Age Dopendent Doses to Memhers of the Public firm Intake of Radionnclides Part 4 Inhalation Dose Cofficients, Annals of the International Commission on Radiation Protection, Volume 25,

Number 3-4, Elsevier Science, Tarrytown, New York; and IC RP-72, 1996, Age Dependent Doses to Me'mbers of the Public from Intake of Radionuclides Part 5 Compilation of Ingestion and Inhalation Dose Coefficients, Annals of the International Commission on Radiological Protection, Volume 26, Number 1, Elsevier Science, Tarrytown. New York

I) $\mathrm{Cl}$-- dose conversion factor.

SST - single-shell tank.

ULD - unit liter dose. 
Table 2-3. Fraction of Unit Liter Dose from Strontium-90, Ytrium-90, Cesium-137 and Gross Alpha for Double-Shell Tank Solids and Liquids for Inhalation.

\begin{tabular}{|c|c|c|c|c|c|}
\hline Isotope & $\begin{array}{l}\text { ICRP-71 and } \\
\text { ICRP-72* } \\
\text { DCF } \\
\text { (Sv/Bq) }\end{array}$ & $\begin{array}{c}\text { DST Liquids } \\
\text { Activity } \\
(\mathbf{B q} / \mathrm{L})\end{array}$ & $\begin{array}{c}\text { DST Liquids } \\
\text { ULD } \\
(\mathrm{Sv} / \mathrm{L})\end{array}$ & $\begin{array}{c}\text { DST Solids } \\
\text { Activity } \\
(\mathbf{B q} / \mathbf{L})\end{array}$ & $\begin{array}{c}\text { DST Solids } \\
\text { ULD } \\
\text { (Sv/L) }\end{array}$ \\
\hline${ }^{610} \mathrm{Co}$ & $1.00 \mathrm{E}-08$ & $6.97 \mathrm{E}+06$ & $6.97 \mathrm{E}-02$ & $1.45 \mathrm{E}+07$ & 1.45 E-01 \\
\hline${ }^{90} \mathrm{Sr}$ & $3.60 \mathrm{E}-08$ & $4.59 \mathrm{E}+09$ & $1.65 E+02$ & $5.16 \mathrm{E}+10$ & $1.86 \mathrm{E}+03$ \\
\hline${ }^{()} \mathrm{Y}$ & $1.50 \mathrm{E}-09$ & $4.59 \mathrm{E}+09$ & $6.89 \mathrm{E}-00$ & $5.16 \mathrm{E}+10$ & $7.74 \mathrm{E}+01$ \\
\hline${ }^{137} \mathrm{Cs}$ & $4.60 \mathrm{E}-09$ & $5.86 \mathrm{E}+10$ & $2.70 \mathrm{E}+02$ & $5.86 \mathrm{E}+10$ & $2.70 \mathrm{E}+02$ \\
\hline${ }^{154} \mathrm{Eu}$ & $5.30 \mathrm{E}-08$ & $4.18 \mathrm{E}+07$ & $2.22 \mathrm{E}-00$ & $3.00 \mathrm{E}+08$ & $1.59 \mathrm{E}+01$ \\
\hline${ }^{237} \mathrm{~Np}$ & $2.30 \mathrm{E}-05$ & $2.30 \mathrm{E}+05$ & $5.29 \mathrm{E}-00$ & $8.11 E+05$ & $1.87 \mathrm{E}+01$ \\
\hline${ }^{238} \mathrm{Pu}$ & $4.60 \mathrm{E}-05$ & $1.78 \mathrm{E}+06$ & $8.19 \mathrm{E}+01$ & $7.15 E+07$ & $3.29 \mathrm{E}+03$ \\
\hline${ }^{239} \mathrm{Pu}$ & $5.00 \mathrm{E}-05$ & $7.65 \mathrm{E}+06$ & $3.83 E+02$ & $1.57 \mathrm{E}+09$ & $7.85 \mathrm{E}+04$ \\
\hline${ }^{241} \mathrm{Pu}$ & $9.00 \mathrm{E}-07$ & $1.84 \mathrm{E}+07$ & $1.66 \mathrm{E}+01$ & $3.81 \mathrm{E}+09$ & $3.43 E+03$ \\
\hline${ }^{241} \mathrm{Am}$ & $4.20 \mathrm{E}-05$ & $3.40 \mathrm{E}+07$ & $1.43 E+03$ & $2.71 \mathrm{E}+09$ & $1.14 \mathrm{E}+05$ \\
\hline${ }^{244} \mathrm{Cm}$ & $2.70 \mathrm{E}-05$ & $1.22 \mathrm{E}+05$ & $3.29 \mathrm{E}-00$ & $1.64 \mathrm{E}+07$ & $4.43 \mathrm{E}+02$ \\
\hline \multicolumn{3}{|c|}{ Total ULD } & $2.36 \mathrm{E}+03$ & & $2.02 \mathrm{E}+05$ \\
\hline \multicolumn{3}{|c|}{${ }^{90} \mathrm{Sr}+{ }^{90} \mathrm{Y}+{ }^{137} \mathrm{Cs}+$ alpha } & $2.34 \mathrm{E}+03$ & & $1.98 \mathrm{E}+05$ \\
\hline \multicolumn{3}{|c|}{${ }^{90} \mathrm{Sr}+{ }^{90} \mathrm{Y}+{ }^{137} \mathrm{Cs}+$ alpha/Total ULD } & 0.99 & & 0.98 \\
\hline
\end{tabular}

*ICRP-71, 1995, Age Dependent Deses to Members of the Public from Intake of Radionuclides Part 4 Inhalation Dose Coefficients, Annals of the International Commission on Radiation Protection. Volume 25.

Number 3-4, Elsevier Science, Tarrytown, New York: and ICRP-72, 1996, Age Dependent Doses to Members of the Public from Intake of Radionuclides Part 5 Compilation of Ingestion and Inhalation Dose Coefficients, Annals of the International Commission on Radiological Protection, Volume 26, Number 1, Elsevier Science. Tarrytown, New York.

DCF ${ }^{i}$ dose conversion factor.

ISST :- double-shell tank.

Ul.D - unit liter dose. 
Table 2-4. Fraction of Unit Liter Dose from Strontium-90, Yttrium-90, Cesium-137 and Gross Alpha for Single-Shell and Double-Shell Tanks for Ingestion.

\begin{tabular}{|c|c|c|c|c|}
\hline Isotope & $\begin{array}{c}\text { SST } \\
\text { Liquids } \\
\left(\mathbf{S v - \mathbf { m } ^ { 3 } / L - s )}\right.\end{array}$ & $\begin{array}{c}\text { SST } \\
\text { Solids } \\
\left(\mathrm{Sv}-\mathbf{m}^{3} / \mathbf{L}-\mathbf{s}\right)\end{array}$ & $\begin{array}{c}\text { DST } \\
\text { Liquids } \\
\left(\mathrm{Sv}-\mathbf{m}^{\mathbf{3}} / \mathbf{L}-\mathbf{s}\right)\end{array}$ & $\begin{array}{c}\text { DST } \\
\text { Solids } \\
\left(\mathrm{Sv}-\mathrm{m}^{3} / \mathbf{L}-\mathbf{s}\right)\end{array}$ \\
\hline${ }^{901} \mathrm{Sr}$ & $2.50 \mathrm{E}-02$ & $3.60 \mathrm{E}+000$ & $1.00 \mathrm{E}-02$ & $1.20 \mathrm{E}-01$ \\
\hline${ }^{40} \mathrm{Y}$ & $2.20 \mathrm{E}-03$ & $3.20 \mathrm{E}-01$ & $9.10 \mathrm{E}-04$ & $1.00 \mathrm{E}-02$ \\
\hline${ }^{1.37} \mathrm{Cs}$ & $2.00 \mathrm{E}-02$ & $9.00 \mathrm{E}-02$ & $5.30 \mathrm{E}-02$ & $5.30 \mathrm{E}-(12$ \\
\hline${ }^{237} \mathrm{~Np}$ & $0.00 \mathrm{E}+00$ & $3.20 \mathrm{E}-03$ & $2.30 \mathrm{E}-05$ & $8.10 \mathrm{E}-05$ \\
\hline${ }^{238} \mathrm{Pu}$ & $5.60 \mathrm{E}-06$ & $1.20 \mathrm{E}-02$ & $1.10 \mathrm{E}-04$ & $4.40 \mathrm{E}-03$ \\
\hline${ }^{239} \mathrm{Pu}$ & $2.40 \mathrm{E}-03$ & $2.90 \mathrm{E}-02$ & $5.20 \mathrm{E}-04$ & $1.10 \mathrm{E}-0) 1$ \\
\hline${ }^{241} \mathrm{Am}$ & $2.90 \mathrm{E}-03$ & $1.60 \mathrm{E}-02$ & $2.30 \mathrm{E}-03$ & $1.90 \mathrm{E}-01$ \\
\hline${ }^{244} \mathrm{Cm}$ & $1.60 \mathrm{E}-05$ & $8.60 \mathrm{E}-05$ & $4.50 \mathrm{E}-06$ & $6.00 \mathrm{E}-04$ \\
\hline Total & $5.25 \mathrm{E}-02$ & $4.07 \mathrm{E}+00$ & $6.69 \mathrm{E}-02$ & $4.88 \mathrm{E}-(01$ \\
\hline \multicolumn{5}{|l|}{ Other } \\
\hline${ }^{\circ 1} \mathrm{Co}$ & $4.60 \mathrm{E}-06$ & $2.00 \mathrm{E}-04$ & $3.40 \mathrm{E}-06$ & $7.20 \mathrm{E}-06$ \\
\hline${ }^{154} \mathrm{Eu}$ & $4.40 \mathrm{E}-04$ & $1.00 \mathrm{E}-03$ & $7.50 \mathrm{E}-06$ & $5.50 \mathrm{E}-05$ \\
\hline${ }^{241} \mathrm{Pu}$ & $3.30 \mathrm{E}-04$ & $4.10 \mathrm{E}-03$ & $2.30 \mathrm{E}-05$ & $4.80 \mathrm{E}-03$ \\
\hline Total & $5.33 \mathrm{~F}-02$ & $4.08 \mathrm{E}+00$ & $6.69 \mathrm{E}-02$ & $4.93 \mathrm{E}-01$ \\
\hline Fraction & $9.85 \mathrm{E}-01$ & 9.99 E-01 & $9.99 \mathrm{E}-01$ & $9.90 \mathrm{E}-01$ \\
\hline
\end{tabular}

ISST double-shell tank.

$\mathrm{SST}=$ single-shell tank.

\subsection{REPRESENTATIVE RADIONUCIIDES SELECTED FOR NEW UNIT LITER DOSE MODEI.}

Based on the work presented in Section 2.2, the following group of radionuclides provides sufficient information to perform dose consequence calculations:

- Cesium-137 directly measured by laboratory

- Strontium-90 directly measured by laboratory

- Yttrium-90 not measured by laboratory but with activity concentration equal to ${ }^{10} \mathrm{Sr}$

- Gross alpha (includes ${ }^{237} \mathrm{~Np},{ }^{2.8} \mathrm{Pu},{ }^{23.9} \mathrm{Pu},{ }^{241} \mathrm{Am}$, and ${ }^{244} \mathrm{Cm}$ ).

A summary of the total percentage contributed by waste type for both inhalation and ingestion doses, using the radionuclides listed above, is presented in the following table. 
Table 2-5. Summary of Fraction from Strontium-90, Yttrium-90, Cesium-137 and Gross Alpha Percent Inhalation and Ingestion Doses.

\begin{tabular}{|l|c|c|}
\hline \multicolumn{1}{|c|}{ Waste Type } & Inhalation Dose (\%) & Ingestion Dose (\%) \\
\hline Single-shell liquid & 92 & 98 \\
\hline Single-shell tank solid & 97 & 99 \\
\hline Double-shell tank liquid & 99 & 99 \\
\hline Double-shell tank solid & 98 & 99 \\
\hline
\end{tabular}

\subsection{AMERICIUM BUILD-UP}

Calculations in WHC-SD-WM-SARR-016 corrected for possible increases in the ${ }^{241} \mathrm{Am}$ concentrations from decay of ${ }^{241} \mathrm{Pu}$. Plutonium-241 decays to ${ }^{241} \mathrm{Am}$, and the half-life of ${ }^{241} \mathrm{Am}$ is 432 years versus 14.4 years for ${ }^{241} \mathrm{Pu}$. Since the half-life of the parent nuclide $\left({ }^{241} \mathrm{Pu}\right)$ is shorter than the half-life of the daughter $\left({ }^{241} \mathrm{Am}\right)$, the potential exists for the ${ }^{241} \mathrm{Am}$ concentration to increase. The calculation in Appendix H of WHC-SD-WM-SARR-016 indicated that the ${ }^{241} \mathrm{Am}$ concentrations could change for the different composites as given in Table 2-6.

Table 2-6. Amcricium-241 Activity as a Function of Time Based on Worst-Case Tank Data.

\begin{tabular}{|c|c|c|c|c|c|c|}
\hline Composite & $\begin{array}{c}\text { Initial } \\
{ }^{241} \mathbf{P u} \\
\text { Activity } \\
(\mathrm{Bq} / \mathrm{L})\end{array}$ & $\begin{array}{c}\text { Initial } \\
{ }^{241} \mathbf{A m} \\
\text { Activity } \\
\text { (Bq/L) }\end{array}$ & $\begin{array}{c}{ }^{241} \text { Am } \\
\text { Activity } \\
\text { after } \\
10 \text { years } \\
(\mathrm{Bq} / \mathrm{L})\end{array}$ & $\begin{array}{c}{ }^{241} \text { Am } \\
\text { Activity } \\
\text { after } \\
20 \text { years } \\
\text { (Bq/L) }\end{array}$ & $\begin{array}{c}{ }^{241} \text { Am } \\
\text { Activity } \\
\text { after } \\
30 \text { years } \\
\text { (Bq/L) }\end{array}$ & $\begin{array}{l}{ }^{241} \text { Am } \\
\text { Activity } \\
\text { after } \\
40 \text { years } \\
\text { (Bq/L) }\end{array}$ \\
\hline $\begin{array}{l}\text { Single-shell } \\
\text { tank liquids }\end{array}$ & $2.80 \mathrm{E}+08$ & $3.70 \mathrm{E}+07$ & $3.99 \mathrm{E}+07$ & $4.15 \mathrm{E}+07$ & $4.22 \mathrm{E}+07$ & $4.23 \mathrm{E}+07$ \\
\hline $\begin{array}{l}\text { Single-shell } \\
\text { tank solids }\end{array}$ & $3.50 \mathrm{E}+09$ & $1.42 \mathrm{E}+08$ & $1.51 \mathrm{E}+08$ & $2.08 \mathrm{E}+08$ & $2.22 E+08$ & $2.29 \mathrm{E}+08$ \\
\hline $\begin{array}{l}\text { Double-shell } \\
\text { tank liquids }\end{array}$ & $2.00 \mathrm{E}+07$ & 3.40 $\mathrm{E}+07$ & $3.37 \mathrm{E}+07$ & $3.33 E+07$ & $3.29 \mathrm{E}+07$ & $3.24 \mathrm{E}+07$ \\
\hline $\begin{array}{l}\text { Double-shell } \\
\text { tank solids }\end{array}$ & $4.10 E+09$ & $2.70 \mathrm{E}+09$ & $2.71 E+09$ & $2.70 \mathrm{E}+09$ & $2.67 \mathrm{E}+09$ & $2.64 \mathrm{~F}+09$ \\
\hline
\end{tabular}

The ${ }^{241} \mathrm{Am}$ concentration in SST liquids increases by about 14 percent over 40 years, and the ${ }^{241} \mathrm{Am}$ concentration in SST solids increases by about 61 percent over 40 years. The ${ }^{241} \mathrm{Am}$ concentrations in DST solids and liquids decrease over 40 years. The ${ }^{241}$ Am concentration can increase or decrease depending on the relative ${ }^{241} \mathrm{Am}$ and ${ }^{2+1} \mathrm{Pu}$ concentrations. The peak ${ }^{2+1} \mathrm{Am}$ values were used in the ULD calculations in WHC-SD-WM-SARR-()16. 
The application of this correction to the ${ }^{241} \mathrm{Am}$ concentration is conservative. However, if this build-up of ${ }^{241} \mathrm{Am}$ is included, the effects of decay of the other radioactive isotopes should also be included. The ${ }^{137} \mathrm{Cs}$ and ${ }^{90} \mathrm{Sr} /{ }^{90} \mathrm{Y}$ activities will decrease by more than a factor of two in 40 years, which will tend to decrease the ULD. An assessment of the ULDs for SST solids and liquids, including the effects of decay and build-up, is shown in Tables 2-7 and 2-8. The ${ }^{241} \mathrm{Am}$ concentrations were taken from Table 2-6. The remaining activities were determined using the isotope half-life

$$
A(t)=A_{0} \operatorname{Exp}\left(-0.693 * t / t_{1 / 2}\right)
$$

where

$$
\begin{aligned}
& \mathrm{A}(\mathrm{t})=\text { activity at time } \mathrm{t} \\
& \mathrm{A}_{0}=\text { initial activity } \\
& \mathrm{t}_{1 / 2}=\text { half-life of isotope. }
\end{aligned}
$$

ULDs are calculated by multiplying the activity by the DCF for each isotope and summing over all the isotopes. The ULDs are shown in Tables 2-7 and 2-8 at 10-year increments. DCFs from ICRP-71 and ICRP-72 are used in Tables 2-7 and 2-8.

Tables 2-7 and 2-8 both indicate that the total ULDs decrease despite the fact that the ${ }^{241} \mathrm{Am}$ contributions increase. Therefore, no correction for ${ }^{241} \mathrm{Am}$ build-up is required because neglecting the decay and build-up is conservative. 
Table 2-7. Unit Liter Dose as a Function of Time for Single-Shell Tank Liquids.

\begin{tabular}{|c|c|c|c|c|c|c|c|c|}
\hline Isotope & \begin{tabular}{|} 
ICRP-71 and \\
ICRP-72 \\
DCF $(S v / B q)$
\end{tabular} & $\begin{array}{c}\text { Activity/L } \\
(\mathbf{B q} / \mathbf{L})\end{array}$ & $\begin{array}{c}\text { ULD } \\
\text { (Sv/L) }\end{array}$ & $\begin{array}{c}\text { Half-Life } \\
\text { (years) }\end{array}$ & $\begin{array}{c}\text { 10-year } \\
\text { ULD } \\
\text { (Sv/L) }\end{array}$ & $\begin{array}{c}\text { 20-year } \\
\text { ULD } \\
(S v / L)\end{array}$ & $\begin{array}{c}\text { 30-year } \\
\text { ULD } \\
\text { (Sv/L) }\end{array}$ & $\begin{array}{l}\text { 40-year } \\
\text { ULD } \\
\text { (Sv/L) }\end{array}$ \\
\hline${ }^{(1)} \mathrm{Co}$ & $1.0 \mathrm{~F}-08$ & $9.5 \mathrm{E}+06$ & $9.5 \mathrm{E}-02$ & $5.3 \mathrm{E} 100$ & $2.6 \mathrm{H}-02$ & $6.9 \mathrm{E}-0.3$ & $1.8 \mathrm{E}-0.3$ & $5.0 \mathrm{E}-04$ \\
\hline${ }^{30} \mathrm{Sr}$ & $3.6[-08$ & $1.1[10$ & $3.8 \mathrm{E}+02$ & $2.9 \mathrm{E}+01$ & $3.0 \mathrm{E}+02$ & $2.3 \mathrm{E}+02$ & $1.8 \mathrm{E} 102$ & $1.4 \mathrm{E} \div 02$ \\
\hline${ }^{4+1)} \mathrm{Y}$ & $1.5 \mathrm{E}-09$ & $1.1 \mathrm{E}+10$ & $1.6 \mathrm{E} 101$ & $2.91 \mathrm{l}+01^{\mathrm{b}}$ & $1.2 \mathrm{E}+01$ & $9.7 \mathrm{E}+00$ & 7.6 E+00 & $6.01+00$ \\
\hline${ }^{1.77} \mathrm{Cs}$ & $4.6[-09$ & $2.21+10$ & $1.0 \mathrm{E}+02$ & $3.0 \mathrm{E}+01$ & $8.14+01$ & $6.4 \mathrm{E}+01$ & $5.1 \mathrm{E}+01$ & $4.1 \mathrm{E}: 01$ \\
\hline${ }^{154} \mathrm{Eu}$ & $5.3 \mathrm{E}-08$ & $2.4 \mathrm{E}+09$ & $1.2 \mathrm{E} 102$ & $8.8 \mathrm{E}+00$ & $5.7 \mathrm{E} \vdash 01$ & $2.61+01$ & $1.2 \mathrm{E}+01$ & $5.31+00$ \\
\hline${ }^{237} \mathrm{~Np}$ & $2.31:-05$ & $0.0 \mathrm{E}+00$ & $0.0 \mathrm{E}+00$ & $2.1 \mathrm{E} 106$ & $0.0 \mathrm{~F}+00$ & $0.0 \mathrm{E} 100$ & $0.0 \mathrm{E}+00$ & $0.0 \mathrm{E}: 00$ \\
\hline${ }^{238 \mathrm{Pu}}$ & $4.6 \mathrm{E}-05$ & $9.2[104$ & $4.2 E 100$ & $8.8 \mathrm{E}+01$ & $3.9 \mathrm{E} 100$ & $3.6 \mathrm{E}+00$ & $3.3 \mathrm{E} \cdot 00$ & $3.1 \mathrm{E}+00$ \\
\hline${ }^{239} \mathrm{Pu}$ & $5.0 \mathrm{H}-05$ & $3.6 \mathrm{E}+07$ & $1.8 \mathrm{E}+03$ & $2.4 \mathrm{E}+04$ & $1.8 \mathrm{E}+03$ & $18 \mathrm{E} 103$ & $1.8 \mathrm{E}+03$ & $1.8 \mathrm{E} \cdot 03$ \\
\hline${ }^{241} \mathrm{Pu}$ & $9.0 \mathrm{E}-07$ & $2.6 E+08$ & $2.3 \mathrm{E}+02$ & $1.4[101$ & $1.4 \mathrm{E}+02$ & 8.81101 & $5.5 \mathrm{E}+01$ & $3.4 \mathrm{E} 401$ \\
\hline $2+1 \mathrm{Am}$ & $4.2 \mathrm{E}-05$ & $3.7 \mathrm{E}+07$ & $1.6 \mathrm{I}+03$ & $4.3 \mathrm{E}+02$ & $1.7 \mathrm{E}+03$ & $1.7 \mathrm{E}+03$ & $1.8 \mathrm{E}+03$ & $1.8 \mathrm{E}+03$ \\
\hline${ }^{2+2} \mathrm{Cm}$ & $2.7 \leqslant-05$ & $4.2 \mathrm{E}+05$ & $1.1 \mathrm{E}+0 \mathrm{~J}$ & $1.8 \mathrm{E} 101$ & $7.7 \mathrm{~J}+00$ & $5.3 \mathrm{E}+00$ & $3.6 \mathrm{E}+00$ & $2.5 \mathrm{E}+00$ \\
\hline $\begin{array}{l}\text { Total } \\
\text { ULD }\end{array}$ & & & $4.2 \mathrm{E}+03$ & & $4.1 E+03$ & $4.0 \mathrm{E}+03$ & $3.9 \mathrm{E}+03$ & $3.8 \mathrm{E}+03$ \\
\hline
\end{tabular}

"ICRP-71, 1995, Age Dependent Doses to Members of the Public firm Intake of Radionuclides Part 4 Inhalation Dose Coefficients, Annals of the International Commission on Radiation Protection, Volume 25, Number 3-4, Elsevier Science, Tarrytown, New York: and ICRP-72, 1996. Age Dependent Doses to Members of the Public from Intake of Radioniclides Pat 5 Compilation of Ingestion and hihalation Dose Cocfficients, Annals of the International Commission on Radiological Protection, Volume 26. Number 1, Elsevier Science, Tarrytown, New York.

${ }^{b}$ The "Y $\mathrm{Y}$ activity is in equilibrium with the "Sr activity.

DC $\mathrm{F}$-..- dose conversion lactor.

UL, I) - unit liter dose. 
Table 2-8. Unit Liter Dose as a Function of Time for Single-Shell Tank Solids.

\begin{tabular}{|c|c|c|c|c|c|c|c|c|}
\hline Isotope & $\begin{array}{c}\text { ICRP-71 and } \\
\text { ICRP-72 } \\
\text { DCF } \\
(\mathrm{Sv} / \mathrm{Bq}) \\
\end{array}$ & $\begin{array}{c}\text { Activity/L } \\
(\mathrm{Bq} / \mathrm{L})\end{array}$ & $\begin{array}{l}\text { ULD } \\
(\mathrm{Sv} / \mathbf{L})\end{array}$ & $\begin{array}{l}\text { Half-Life } \\
\text { (years) }\end{array}$ & $\begin{array}{c}\text { 10-year } \\
\text { UL.D } \\
(\mathrm{Sv} / \mathrm{L})\end{array}$ & $\begin{array}{c}20 \text { year } \\
\text { ULD } \\
(\text { Sv/L) }\end{array}$ & $\begin{array}{c}\text { 30-year } \\
\text { ULD } \\
\text { (Sv/L) }\end{array}$ & $\begin{array}{c}\text { 40-year } \\
\text { ULD } \\
(\text { Sv/L) }\end{array}$ \\
\hline${ }^{60} \mathrm{Co}$ & $1.0 \mathrm{E}-08$ & $4.2 \mathrm{E}+08$ & $4.2 \mathrm{E}+00$ & $5.3 \mathrm{~F}+(0)$ & $1.1 \mathrm{E}+00$ & $3.0 \mathrm{E}-0 \mathrm{t}$ & $8.1 \mathrm{E}-02$ & $2.2 \mathrm{E}-02$ \\
\hline${ }^{10} \mathrm{Sr}$ & $3.6 \mathrm{E}-08$ & $1.6 \mathrm{E}+12$ & $5.9 \mathrm{E}+(04$ & $2.9 \mathrm{E}+01$ & $4.6 \mathrm{E}+04$ & $3.6 \mathrm{E}+04$ & $2.8 \mathrm{E}+04$ & $2.2 E+04$ \\
\hline${ }^{90} \mathrm{Y}$ & $1.5 \mathrm{~F}-09$ & $1.6 E+12$ & $2.4 \Gamma++03$ & $2.9 \mathrm{E}+01^{\mathrm{b}}$ & $1.9 E+03$ & $1.5 E+03$ & $1.2 \mathrm{E}+03$ & $9.35+02$ \\
\hline${ }^{1.37} \mathrm{Cs}$ & $4.6 \mathrm{E}-(09$ & $1.0 \mathrm{E}+11$ & 4.6E+02 & $3.0 \mathrm{E}+01$ & $3.7 \mathrm{E}+02$ & $2.9 \mathrm{E}+02$ & $2.3 \mathrm{E}+02$ & $1.9 E+02$ \\
\hline${ }^{15-1} \mathrm{Eu}$ & $5.31:-08$ & $5.81 i+109$ & $3.0 \mathrm{E}:+02$ & $8.81 \vdots+00$ & $1.4 \mathrm{E}+02$ & $6.3[i+0]$ & $2.9 \mathrm{E}+01$ & $1.3 \mathrm{E}+01$ \\
\hline${ }^{2.37} \mathrm{~Np}$ & $2.3 \mathrm{E}-0.5$ & $3.0 \mathrm{E}+07$ & $6.9 \mathrm{E}+02$ & $2.1 \mathrm{E}+06$ & $6.9 \mathrm{E}+02$ & $6.9 \mathrm{E}+02$ & $6.9 \Gamma+02$ & $6.9 \mathrm{E}+02$ \\
\hline${ }^{2.38} \mathrm{P}^{2} \mathrm{u}$ & $4.6 \mathrm{E}-0.5$ & $1.9 \mathrm{E}+08$ & $8.6 \mathrm{E}+03$ & $8.8 E+01$ & $7.91 \vdots+03$ & $7.3[i+0.3$ & $6.8 E+03$ & $6.3 E+03$ \\
\hline${ }^{23(9)} \mathrm{Pu}$ & $5.0 \mathrm{E}-05$ & $4.4 E+08$ & $2.2 \mathrm{E}+04$ & $2.4 \mathrm{E}+(04$ & $2.2 \mathrm{E}+() 4$ & $2.2 \mathrm{E}+04$ & $2.2 E+04$ & $2.2 \mathrm{E}+(04$ \\
\hline${ }^{2+11} \mathrm{Pu}$ & $9.0 \mathrm{:}:-07$ & $3.2 \mathrm{E}+(19)$ & $2.9 \mathrm{E}+(93$ & $1.4 \mathrm{E}+0 \mathrm{l}$ & $1.81 i+03$ & $1.11 i+03$ & $6.81 i+02$ & $4.2 \mathrm{E}+02$ \\
\hline${ }^{2 ! 1} \mathrm{Am}$ & $4.2 \mathrm{E}-05$ & $1.4 \mathrm{E}+08$ & $6.0 \mathrm{E}+03$ & $4.3 \mathrm{E}+02$ & $6.3 \mathrm{E}+03$ & $8.7 \mathrm{E}+03$ & $9.3 \mathrm{E}+0.3$ & $9.6 E+03$ \\
\hline${ }^{2+2} \mathrm{Cm}$ & $2.7 \mathrm{E}-05$ & $2.3 \mathrm{E}+06$ & $6.2 \mathrm{E}+01$ & $1.8 \mathrm{E}+01$ & $4.2 \mathrm{E}+01$ & $2.9 E+01$ & $2.01 i+01$ & $1.3 \mathrm{E}:+0]$ \\
\hline Total ULD & & & $1.0 \mathrm{E}+05$ & & $8.7 \mathrm{E}+04$ & $7.8 \mathrm{E}+04$ & $6.9 \mathrm{E}+04$ & $6.2 \mathrm{E}+04$ \\
\hline
\end{tabular}

"ICRP-71, 1995, Age Dependent Doses to Members of the Public from Intake of Radionuclides Part 4 Inhalation Dose Coefficients, Annals of the International Commission on Radiation Protection. Volume 25, Number 3-4, Elsevier Science, Tatrytown, New York, or ICRP-72, 1996, Age Dependent Doses to Members of the Public from Intake of Radiomaclides Part 5 Compilation of Inhalation Dose Coefficients, Annals of the Intemational Commission on Radiation Protection, Volume 26. Number 1, Elsevier Seience, Tarrylown, New York.

${ }^{17}$ The ${ }^{\%} \mathrm{Y}$ activity is in equilibrium with the ${ }^{\text {"S }} \mathrm{Sr}$ atclivity.

$\mathrm{DCF}^{\mathrm{P}}=$ dose conversion factor.

ULD = unit liter dose. 


\subsection{INTERNATIONAL COMMISSION ON RADIATION PROTECTION RECOMMENDED DOSE CONVERSION FACTORS}

\subsection{INTRODUCTION}

The ULD calculations for early versions of the FSAR (HNF-SD-WM-SAR-067) use DCFs from ICRP-26 and ICRP-30, which were issued in 1977 and 1979 by the ICRP. The ICRP modified its internal dose conversion model in 1990, which resulted in the generation of different DCFs. ICRP-68 gives updated DCFs for workers and ICRP-71 and ICRP-72 give updated DCFs for the public (offsite receptor). Section 3.1 discusses the ICRP methods and the impact of changing methods. Section 3.2 documents a calculation of the doses to the onsite worker using the updated methodology given in ICRP-68. Section 3.3 discusses evaluation of the doses to the offsite receptor using updated methodology given in ICRP-71. Section 3.4 presents average DCFs for alpha emitters based on the methodology in ICRP-68 and ICRP-71.

The onsite breathing rate is $3.33 \times 10^{-4} \mathrm{~m}^{3} / \mathrm{s}$. The offsite breathing rate for releases of less than 24-hours duration is $3.33 \times 10^{-4} \mathrm{~m}^{3} / \mathrm{s}$. For offsite releases of more than 24-hours duration, the breathing rate is $2.57 \times 10^{-4} \mathrm{~m}^{3} / \mathrm{s}$.

\subsection{DISCUSSION OF INTERNATIONAL COMMISSION ON RADIATION PROTECTION METHODS}

The principal differences in the updated ICRP methods are a revised lung model and refined weighting factors for several organs. These revised DCFs are documented in ICRP-61, Annual Limits on Intake of Radionuclides by Workers Based on the 1900 Recommendations; the corrected factors for the onsite worker are given in ICRP-68, and the corrected factors for the public are given in ICRP-71 and ICRP-72.

While the DCFs from ICRP-68 and ICRP-71 represent an update and presumed improvement to the modeling of doses from inhalation and ingestion of radioactive materials, the factors are not uniformly accepted. The U.S. Department of Energy (DOE) orders and standards that control safety analysis documents (DOE Order 5480.23, Nuclear Safety Analysis Reports, and DOE-STD-3009-94, Preparation Guide for U.S. Department of Energy Nonreactor Nuclear Facility Safety Analysis Reports) do not specify the details of the method to be used for the dose calculations. The controlling regulation for dose calculation for protection of the workers and the public at DOE facilities is 10 CFR 835, "Occupational Radiation Protection." The current version of 10 CFR 835 does not mention ICRP-26 explicitly. However, the data and definitions in 10 CFR 835 are based on ICRP-26. For instance, for computing occupational exposures, Section 835.203 states: "Determination of the effective dose equivalents shall be made using the weighting factors in Section 835.2." The weighting factors in 10 CFR 835.2 are taken from ICRP-26. ICRP-68 uses different weighting factors.

ICRP-26 is referenced in other orders. DOE O 435.1, Radioactive Waste Management, establishes the requirements for managing radioactive waste. In Appendix A, "Technical Basis and Considerations for DOE M 435.1," the requirement is given that doses to the public shall not 
exceed 25 mrem $(0.25 \mathrm{mSv})$ in a year. The statement is made: "Changes were made to make the requirement clear that the dose calculation is to be consistent with ICRP-26 and ICRP-30." There are similar references in other documents. DOE Order 6430.1A, General Design Criteria, Section IV. P, specifies a 25 -rem whole body dose as a siting guideline "when calculated by using ICRP-26 weighting factors." DOE Order 6430.1A has been replaced but is still referenced by other documents. However, the DCFs from ICRP-68 and ICRP-71 are based on current models and allow more representative calculations to be made for both the onsite workers and the public.

\subsection{ONSITE DOSE CONVERSION FACTORS}

DCFs are given for up to three lung clearance classes for each isotope. ICRP-68 uses the notation of $\mathrm{F}, \mathrm{M}$, and $\mathrm{S}$ (fast, moderate, and slow) for clearance class rather than the $\mathrm{D}, \mathrm{W}$, and $\mathrm{Y}$ (daily, weekly, and yearly) that are used by ICRP-26. The clearance class depends on the chemical compound of the isotope and how the human body processes the compound. The clearance class that produces the largest doses is used in this report for each isotope except for

${ }^{90} \mathrm{Sr}$. Class " $\mathrm{D}$ " is used in an earlier version of the FSAR (HNF-SD-WM-SAR-067) for ${ }^{90} \mathrm{Sr}$ rather than the larger " $Y$ " factor because the only strontium compound that is in the "Y" class is $\mathrm{SrTiO}_{3}$, which is not expected to be found in the Hanford Site waste. The "F" clearance factor is therefore used for ${ }^{90} \mathrm{Sr}$ rather than the larger " $\mathrm{S}$ " factor for the calculation with the ICRP-61 and ICRP-68 DCFs. The DCFs are shown in Table 3-1 for both the ICRP-26 and ICRP-68 models.

The ICRP-68 inhalation DCFs are given for both a $1-\mu \mathrm{m}$ and $5-\mu \mathrm{m}$ activity median aerodynamic diameter (AMAD) particle size. Both sets of factors are given in Table 3-1. The 5- $\mu$ m AMAD values are smaller for the transuranic isotopes and result in lower ULDs for the RPP isotope mixes. ICRP-68 states in Section 2.1: "For occupational exposure the default value now recommended for the Activity Median Aerodynamic Diameter (AMAD) is $5 \mu \mathrm{m}$ (ICRP-68, Paragraph 181), which is considered to be more representative of workplace aerosols than the $1 \mu \mathrm{m}$ value adopted in ICRP Publication 30." The Safety Evaluation Report (TWRS-RT-SER-003) of the FSAR (HNF-SD-WM-SAR-067) also recommends the use of $5 \mu \mathrm{m}$ data. DOE-HDBK-3010-94, Airborne Release Fractions/Rates and Respirable Fractions for Nonreactor Nuclear Facilities, considers particles less than $10 \mu \mathrm{m}$ in diameter as respirable. The use of the $5 \mu \mathrm{m}$ DCFs, therefore, appears justifiable. This may need to be evaluated for each accident scenario to ensure that conservative data are used.

The 24-hour ingestion doses in the FSAR (HNF-SD-WM-SAR-067) are calculated with the GENII computer code (PNL-6584). The GENII code uses the ICRP-26 DCFs. A new version of GENII is planned that will include ICRP-68 factors, but it is not now available in a version that has the proper documentation for safety analysis. Since the 24-hour ingestion dose is a relatively small contributor to the total dose, attempting to update the ingestion doses is not recommended at this point. 
Table 3-1. Inhalation Dose Conversion Factors.

\begin{tabular}{|c|c|c|c|}
\hline Isotope & $\begin{array}{c}\text { ICRP-26 }{ }^{\mathrm{a}} \mathrm{DCF} \\
(\mathrm{Sv} / \mathrm{Bq})\end{array}$ & $\begin{array}{c}\text { ICRP-68 DCF } \\
\text { 1- } \text { Im }^{\mathrm{A}} \mathrm{AMA} \\
(\mathrm{Sv} / \mathrm{Bq})\end{array}$ & $\begin{array}{c}\text { ICRP-68 }{ }^{\mathrm{b}} \text { DCF } \\
5-\mu \mathrm{m} \text { AMAD } \\
(\mathrm{Sv} / \mathrm{Bq})\end{array}$ \\
\hline${ }^{6(1)} \mathrm{Co}$ & $5.91 \mathrm{E}-08$ & $2.9 \mathrm{E}-08$ & $1.7 \mathrm{E}-08$ \\
\hline${ }^{100} \mathrm{Sr}$ & $6.47 \mathrm{E}-08$ & $2.4 \mathrm{E}-08$ & 3.0 E-08 \\
\hline${ }^{101} \mathrm{Y}$ & $2.28 \mathrm{E}-09$ & $1.5 \mathrm{E}-09$ & $1.7 \mathrm{E}-09$ \\
\hline${ }^{137} \mathrm{Cs}$ & 8.63 E- -09 & $4.8 \mathrm{E}-(09$ & $6.7 \mathrm{E}-09$ \\
\hline${ }^{154} \mathrm{Eu}$ & $7.73 \mathrm{E}-08$ & $5.0 \mathrm{E}-08$ & $3.5 \mathrm{E}-(08$ \\
\hline${ }^{237} \mathrm{~Np}$ & $1.46 \mathrm{E}-04$ & $2.1 \mathrm{E}-05$ & $1.5 \mathrm{E}-05$ \\
\hline${ }^{238} \mathrm{Pu}$ & $1.06 \mathrm{E}-04$ & $4.3 \mathrm{E}-(05$ & $3.0 \mathrm{E}-05$ \\
\hline $239 / 240 \mathrm{Pu}$ & $1.16 \mathrm{E}-04$ & $4.7 \mathrm{E}-05$ & $3.2 \mathrm{E}-05$ \\
\hline${ }^{241} \mathrm{Pu}$ & $2.23 \mathrm{E}-06$ & 8.5 E-(07 & $5.8 \mathrm{E}-07$ \\
\hline${ }^{241} \mathrm{Am}$ & $1.20 \mathrm{E}-04$ & $3.9 \mathrm{E}-05$ & $2.7 \mathrm{E}-(05$ \\
\hline${ }^{244} \mathrm{Cm}$ & $6.70 \mathrm{E}-05$ & $2.5 \mathrm{E}-05$ & $1.7 \mathrm{E}-05$ \\
\hline
\end{tabular}

${ }^{2}$ ICRP-26, 1977, Recommendations of the Intconational Commission on Radiological Protection, Annals of the International Commission on Radiation Protection, Volume 1, Number 3, lisevier Science, Tarrytown, New York.

'HC'RP-68, 1994, Dose Coefficients for Intakes of Radionuclides by Workers . Replacement of ICRP Publication 6/, Annals of the International Commission on Radiological Protection, Volume 24. Number 4, Elsevier Science, Tarrylown, New York.

AMAD - activity median aerodynamic diameter.

DCF - - dose conversion factor.

\subsection{OFFSITE RECEPTOR DOSE CONVERSION FACTORS}

ICRP-71 and ICRP-72 give age-dependent doses for members of the public. ICRP-71 discusses the methods, and ICRP-72 gives a summary of the DCFs. There are several differences between the ICRP-68 data and the ICRP-71 data. The following is a summary of the differences.

- DCFs in ICRP-71 and ICRP-72 are given for different ages: 3 months, 1 year, 5 years, 10 years, 15 years, and adult. In general, DCFs for infants are about a factor of two higher than for adults, and intermediate ages show intermediate DCFs. The data in ICRP-71 indicate that the breathing rate in cubic metcrs per second is lower for the younger ages. Dose is a function of both DCF and breathing rate. The products of DCF times breathing rate for the different ages and isotopes are given in Table 3-2. The product of breathing rate and DCF is highest for the adult for the dominant isotopes. Therefore, using the adult factors is reasonable. 
Table 3-2. Comparison of Dose Conversion Factor Times Breathing Rates for Receptors of Various Ages.

\begin{tabular}{|c|c|c|c|c|c|c|}
\hline Age & 3 months & 1 year & 5 years & 10 years & 15 years & Adult \\
\hline $\begin{array}{l}\text { Air breathed in } \\
24 \text { hours }\left(\mathrm{m}^{3}\right)^{*}\end{array}$ & 2.86 & 5.16 & 8.72 & 15.3 & 20.1 & 22.2 \\
\hline $\begin{array}{l}\text { Average breathing rate } \\
\left(\mathrm{m}^{3} / \mathrm{s}\right)\end{array}$ & $3.31 \mathrm{E}-5$ & $5.97 \mathrm{E}-05$ & $1.01 \mathrm{E}-04$ & 1.77 E-04 & $2.33 \mathrm{E}-04$ & $2.57 \mathrm{E}-04$ \\
\hline${ }^{90} \mathrm{Sr}$ DCF $(\mathrm{Sv} / \mathrm{Bq})$ & $1.5 \mathrm{E}-07$ & $1.1 \mathrm{E}-07$ & $6.5 \mathrm{E}-08$ & $5.1 \mathrm{E}-08$ & $5.0 \mathrm{E}-08$ & $3.6 \mathrm{E}-08$ \\
\hline $\begin{array}{l}{ }^{90} \mathrm{Sr} \text { DCF times } \\
\text { breathing rate } \\
\left(\mathrm{Sv}-\mathrm{m}^{3} / \mathrm{Bq}-\mathrm{s}\right)\end{array}$ & $5.0 \mathrm{E}-12$ & $6.6 \mathrm{E}-12$ & $6.6 \mathrm{E}-12$ & $9.0 \mathrm{E}-12$ & $1.16 \mathrm{E}-11$ & $9.3 \mathrm{E}-12$ \\
\hline${ }^{90} \mathrm{Y} \mathrm{DCF}$ & $1.3 \mathrm{E}-08$ & $8.8 \mathrm{E}-09$ & $4.2 \mathrm{E}-(09$ & $2.7 \mathrm{E}-09$ & $1.8 \mathrm{E}-09$ & $1.5 \mathrm{E}-09$ \\
\hline $\begin{array}{l}{ }^{90} \mathrm{Y} \mathrm{DCl}^{-} \text {times } \\
\text { breathing rate } \\
\left(\mathrm{Sv}-\mathrm{m}^{3} / \mathrm{Bq}-\mathrm{s}\right)\end{array}$ & $4.3 \mathrm{E}-13$ & $5.3 \mathrm{E}-13$ & $4.2 \mathrm{E}-13$ & $4.8 \mathrm{E}-13$ & $4.2 \mathrm{E}-13$ & $3.9 \mathrm{E}-13$ \\
\hline${ }^{137} \mathrm{Cs} \mathrm{DCF}$ & $8.8 \mathrm{E}-09$ & $5.4 \mathrm{E}-09$ & $3.6 \mathrm{E}-(09$ & $3.7 \mathrm{E}-09$ & $4.4 \mathrm{E}-09$ & $4.6 \mathrm{E}-09$ \\
\hline $\begin{array}{l}{ }^{137} \mathrm{Cs} \mathrm{DCF} \text { times } \\
\text { breathing rate } \\
\left(\mathrm{Sv}-\mathrm{m}^{3} / \mathrm{Bq}^{-\mathrm{s}}\right)\end{array}$ & $2.9 \mathrm{E}-13$ & $3.2 \mathrm{E}-13$ & $3.6 \mathrm{E}-13$ & $6.6 \mathrm{E}-13$ & $1.0 \mathrm{E}-12$ & $1.2 \mathrm{E}-12$ \\
\hline${ }^{238} \mathrm{Pu}$ DCF $(\mathrm{Sv} / \mathrm{Bq})$ & $7.8 \mathrm{E}-05$ & $7.4 \mathrm{E}-0.5$ & $5.6 \mathrm{E}-05$ & $4.4 \mathrm{E}-05$ & $4.3 \mathrm{E}-(05$ & $4.6 \mathrm{E}-05$ \\
\hline $\begin{array}{l}{ }^{238} \mathrm{Pu} \text { DCF times } \\
\text { breathing rate } \\
\left(\mathrm{Sv}-\mathrm{m}^{3} / \mathrm{Bq}-\mathrm{s}\right)\end{array}$ & $2.6 \mathrm{E}-09$ & $4.4 \mathrm{E}-09$ & $5.7 \mathrm{E}-09$ & $7.8 \mathrm{E}-09$ & $1.0 \mathrm{E}-08$ & $1.2 \mathrm{E}-08$ \\
\hline${ }^{239} \mathrm{Pu} \mathrm{DCF}(\mathrm{Sv} / \mathrm{Bq})$ & 8.0 E-05 & 7.7 E-05 & $6.0 \mathrm{E}-05$ & $4.8 \mathrm{E}-05$ & $4.7 \mathrm{E}-05$ & $5.0 \mathrm{E}-05$ \\
\hline $\begin{array}{l}{ }^{234} \mathrm{Pu} \text { DCF times } \\
\text { breathing rate } \\
\left(\mathrm{Sv}-\mathrm{m}^{3} / \mathrm{Bq}-\mathrm{s}\right)\end{array}$ & $2.7 \mathrm{E}-09$ & $4.6 \mathrm{E}-(09$ & $6.1 \mathrm{E}-09$ & $8.5 \mathrm{E}-09$ & $1.1 \mathrm{E}-08$ & $1.3 \mathrm{E}-08$ \\
\hline${ }^{241} \mathrm{Am} \mathrm{LCF}(\mathrm{Sv} / \mathrm{Bq})$ & 7.3 E- 05 & $6.9 \mathrm{E}-05$ & $5.1 \mathrm{E}-05$ & $4.0 \mathrm{E}-05$ & $4.0 \mathrm{E}-05$ & 4.2 E-05 \\
\hline $\begin{array}{l}{ }^{241} \text { Am DCF times } \\
\text { breathing rate } \\
\left(\mathrm{Sv}-\mathrm{m}^{3} / \mathrm{Bq}-\mathrm{s}\right)\end{array}$ & 2.4 E-09 & $4.1 \mathrm{E}-09$ & $5.2 \mathrm{E}-09$ & $7.1 \mathrm{E}-09$ & $9.3 \mathrm{E}-09$ & 1.1 E-08 \\
\hline
\end{tabular}

Note: DCFs for all isolopes except ${ }^{10} \mathrm{Y}$ are from ICRP-71, 1995, Age Dependent Doses to Members of the Public from Intake of Radionuclides Part 4 Inhalation Dose Coefficients, Annals of the International Commission on Radiation Protection, Volume 25. Number 3-4, Elsevier Science, Tarrytown, New York. DCFis for "Y Yre from ICRP-72, 1996, Age Dependent Doses to Members of the Public from Intake of Radionuclides Part 5 Compilation of Ingestion and Irhalation Dose Coefficients, Annals of the International Commission on Radiation Protection, Volume 26, Number 1, Elsevier Science, Tarrylown, New York.

*Breathing rate lor different ages from Table 6 of ICRP-7I.

$\mathrm{DCF}=$ dose conversion lactor. 


\section{RPP-5924 REV 0}

- DCFs are given only for 1- $\mu \mathrm{m}$ AMAD in ICRP-71 and ICRP-72 (i.e., no 5- $\mu \mathrm{m}$ data are given). ICRP-71 indicates in Section 2.3: "For environmental exposure, the default AMAD is taken to be $1 \mu \mathrm{m}$."

- ICRP-68 presents data for two clearance classes, $\mathrm{M}$ and $\mathrm{S}$, for transuranic isotopes. ICRP-71 and ICRP-72 give data for three clearance classes, F, M, and S, for the transuranic isotopes. The class F DCFs are largest. However, the statement is made for americium, neptunium, plutonium, and curium in ICRP-71: "Default Type $M$ is recommended for use in the absence of specific information." Class $M$ data are used in Table 3-2.

- ICRP-68 presents data for two clearance classes, $\mathrm{F}$ and $\mathrm{S}$, for ${ }^{90} \mathrm{Sr}$. The $\mathrm{S}$ class DCF is larger. The class F DCF is used because only one strontium compound has $\mathrm{S}$ characteristics $\left(\mathrm{SrTiO}_{2}\right)$ and that compound is not expected to be found in Hanford Site waste. ICRP-72 gives data for three clearance classes, F, M, and S. ICRP-71 recommends the use of the $\mathrm{M}$ class unless specific data are known. The $\mathrm{M}$ class data from ICRP-71 were used in Table 3-2. Thus, the ${ }^{90} \mathrm{Sr}$ calculations for onsite workers and offsite public are based on different clearance classes.

- The $\mathrm{F}$ clearance class is recommended in ICRP-71 for ${ }^{137} \mathrm{Cs}$. F data are used for this isotope.

- Data for ${ }^{90} \mathrm{Y}$ and ${ }^{154} \mathrm{Eu}$ are not included in ICRP-71. Maximum DCFs were taken from ICRP-72 for ${ }^{90} \mathrm{Y}$ and ${ }^{154} \mathrm{Eu}$.

The first bullet above indicates that doses to aduits are larger than doses to children. This conclusion is supported by the following calculation for doses due to inhalation of a given isotope:

$$
\mathrm{D}=(\mathrm{Q})\left(\mathrm{X} / \mathrm{Q}^{\prime}\right)(\mathrm{BR})(\mathrm{DCF})
$$

where

$$
\begin{aligned}
& \mathrm{D}=\text { dose to the receptor } \\
& \mathrm{Q}=\text { amount of a given isotope released } \\
& \mathrm{X} / \mathrm{Q}^{\prime}=\text { the atmospheric dispersion coefficient } \\
& \mathrm{BR}=\text { breathing rate } \\
& \mathrm{DCF}=\text { dose conversion factor for the isotope. }
\end{aligned}
$$


The doses are proportional to the breathing rate times the DCF. The product of the average breathing rate and the DCF is given in Table 3-2 for receptors of various ages for the isotopes that are significant contributors to the inhalation dose. The dose to adults is the largest with two exceptions:

1. The dose to the 15 -year old is about 25 percent higher than the dose to the adult for ${ }^{90} \mathrm{Sr}$

2. The doses for ${ }^{90} \mathrm{Y}$ for all the younger ages are significantly larger than the doses for adults.

It can, however, be seen from examining the tables of HNF-4754, Tank Waste Isotope Contributions, that the ULDs are dominated by the transuranics. The adult dose is largest for the transuranics. Yttrium-90 is a relatively small contributor to the dose (about 1 percent or less). Strontium-90 can contribute up to about 48 percent of the dose for SST solids. The remainder is almost all from transuranics. The adult doses from transuranics are about 20 percent higher than the closest children's dose. The use of the adult doses for comparison to risk guidelines is therefore reasonable. The DCFs from ICRP-71 and ICRP-72 for offsite adult receptors are given in Table 3-3. The data from ICRP-68 for $5 \mu \mathrm{m}$ are also repeated in this table for comparison.

The DCFs from ICRP-71 and ICRP-72 are slightly larger for most isotopes than the DCFs from ICRP-68. The DCF for ${ }^{90} \mathrm{Sr}$ is larger because of the difference in clearance class. ICRP-71 computes the dose to age 70 assuming the adult is 17 years old, therefore resulting in a 53-year dose. ICRP-68 DCFs are based on a 50-year dose.

\subsection{AVERAGE DOSE CONVERSION FACTORS FOR ALPHA EMITTERS}

Sample data from the tanks frequently give total alpha activity rather than activity from specific isotopes. A calculation of the effective DCFs for all the alpha-emitting isotopes was made using the DCFs from ICRP-26 (WHC-SD-WM-SARR-016). This calculation has been repeated using the DCFs from ICRP-68 for workers and the DCFs from ICRP-71 and ICRP-72 for the offsite receptor. These DCFs can be used with the total alpha activity in the same way that the DCFs for specific isotopes are multiplied by the isotope activity. Effective DCFs for the alpha-emitters for each composite are calculated using the following formula:

$$
\mathrm{DCF}_{\text {eff }}=\sum \frac{\sum\left(\mathrm{DCF}_{i}\right)\left(\mathrm{A}_{\mathrm{i}}\right)}{\sum\left(\mathrm{A}_{\mathrm{i}}\right)}
$$

where

$$
\begin{aligned}
& \mathrm{DCF}_{\text {eff }}=\text { effective dose conversion factor } \\
& \mathrm{DCF}_{\mathrm{i}}=\text { dose conversion factors for the } i \text { th isotope } \\
& \mathrm{A}_{\mathrm{i}} \quad=\text { activity of the } i \text { th isotope. }
\end{aligned}
$$


Table 3-3. Dose Conversion Factors for Offsite Receptors.

\begin{tabular}{|c|c|c|}
\hline Isotope & $\begin{array}{c}\text { ICRP-71 and ICRP-72 } \\
1 \text { - }{ }^{\mathrm{b}} \mathrm{m} \text { DCFs } \\
(\mathrm{Sv} / \mathrm{Bq})\end{array}$ & $\begin{array}{c}\text { ICRP-68 }{ }^{\mathrm{c}} \mathbf{5}-\mu \mathrm{m} \text { DCFs } \\
(\mathrm{Sv} / \mathbf{B q})\end{array}$ \\
\hline${ }^{60)} \mathrm{Co}$ & $1.0 \mathrm{E}-08^{*}$ & $1.7 \mathrm{E}-08$ \\
\hline${ }^{91} \mathrm{Sr}$ & $3.6 \mathrm{E}-08^{*}$ & $3.0 \mathrm{E}-08$ \\
\hline${ }^{90} \mathrm{Y}$ & $1.5 \mathrm{E}-09 * * *$ & $1.7 \mathrm{E}-09$ \\
\hline${ }^{137} \mathrm{Cs}$ & $4.6 \mathrm{E}-09^{* * *}$ & $6.7 \mathrm{E}-09$ \\
\hline${ }^{154} \mathrm{Eu}$ & $5.3 \mathrm{E}-08 * * *$ & $3.5 \mathrm{E}-08$ \\
\hline${ }^{237} \mathrm{~Np}$ & $2.3 \mathrm{E}-05^{*}$ & $1.5 \mathrm{E}-05$ \\
\hline${ }^{238} \mathrm{Pu}$ & $4.6 \mathrm{E}-05^{*}$ & $3.0 \mathrm{E}-05$ \\
\hline${ }^{239 / 240} \mathrm{Pu}$ & $5.0 \mathrm{E}-05^{*}$ & $3.2 \mathrm{E}-05$ \\
\hline${ }^{241} \mathrm{Pu}$ & $9.0 \mathrm{E}-07^{*}$ & $5.8 \mathrm{E}-07$ \\
\hline${ }^{241} \mathrm{Am}$ & $4.2 \mathrm{E}-05^{*}$ & $2.7 \mathrm{E}-05$ \\
\hline${ }^{2+4 \cdot 4} \mathrm{Cm}$ & $2.7 \mathrm{E}-05^{*}$ & 1.7 E-05 \\
\hline
\end{tabular}

"ICRP-71, 1995, Age Dependent Doses to Members of the Public from Intake of Radionaclides Part 4 lihalation Dose Coefficients, Annals of the International Commission on Raldiation Protection, Volume 25, Number 3-4, Elsevier Science, Tarrytown, New York.

"ICRP-72, 1996, Age Dependent Ioses to Members of the Public from Intake of Radionuclides Part 5 Compilation of Ingestion and Imhalation Dese Coefficients, Annals of the International Commission on Radiation Protection, Volume 26, Number 1, Fisevier Science, Tarrytown, New York.

"ICRP-68, 1994, Dose Coefficients for Intakes of Radionuclides by WorkersReplacement of ICRP Publication 6/, Annals of the International Commission on Radiation Protection, Volume 24, Number 4, Elsevier Science, Tarrylown, New York.

*Class $\mathrm{M}$ data

**Class Fi data

**** Maximum value from [CRP-72

$\mathrm{DCF}=$ dose conversion factor.

The alpha emitting isotopes are ${ }^{237} \mathrm{~Np},{ }^{238} \mathrm{Pu},{ }^{239} \mathrm{Pu},{ }^{241} \mathrm{Am}$, and ${ }^{244} \mathrm{Cm}$. The results are summarized in Table 3-4, and the detailed calculations are shown in Appendix B for ICRP-68 for both $1-\mu \mathrm{m}$ and 5- $\mu \mathrm{m}$ AMAD and for ICRP-71 and ICRP-72. Activitics are based on the "supertank" values from WHC-SD-WM-SARR-016.

\subsection{BREATHING RATE}

Table 1 of ICRP-68 derives a breathing rate for light work assuming the individual spends 2.5 hours sitting with a breathing rate of $0.54 \mathrm{~m}^{3} / \mathrm{h}$, and 5.5 hours at light exercise with a breathing rate of $1.5 \mathrm{~m}^{3} / \mathrm{h}$. The total quantity breathed in 8 hours is $9.6 \mathrm{~m}^{3}$, giving an average breathing rate of $3.33 \times 10^{-4} \mathrm{~m}^{3} / \mathrm{s}$. This is the light-activity breathing rate that is used in the 
FSAR (HNF-SD-WM-SAR-067). While the peak breathing rate is higher, use of the lightactivity value is reasonable since it reflects an average of typical activities during a working day.

Table 6 of ICRP-71 indicates that the breathing rate for the offsite adult receptor is calculated assuming the receptor spends 6 hours sitting at a breathing rate of $0.54 \mathrm{~m}^{3} / \mathrm{h}, 9.75$ hours at light exercise at a breathing rate of $1.5 \mathrm{~m}^{3} / \mathrm{h}, 0.25$ hours at heavy exercise at breathing rate of $3.0 \mathrm{~m}^{3} / \mathrm{h}$, and 8 hours sleeping at a breathing rate $0.45 \mathrm{~m}^{3} / \mathrm{h}$. The total air breathed in 24 hours is $22.2 \mathrm{~m}^{3}$ for an average breathing rate of $2.57 \times 10^{-4} \mathrm{~m}^{3} / \mathrm{s}$. This is an average breathing rate. Since many releases in the FSAR (HNF-SD-WM-SAR-067) are considerably shorter than 24 hours, it would be conservalive to use the light-activity breathing rate for short releases $\left(3.33 \times 10^{-4} \mathrm{~m}^{3} / \mathrm{s}\right)$, but the $2.57 \times 10^{-4} \mathrm{~m}^{3} / \mathrm{s}$ could be used for releases of 24 hours or longer.

Table 3-4. Effective Dose Conversion Factors for Alpha-Emitters for Different Composites Based on Dose Conversion Factors from ICRP-68 and ICRP-7l.

\begin{tabular}{|c|c|c|c|}
\hline Composite & $\begin{array}{l}\text { Effective DCF from } \\
\text { ICRP-68 for Tank } \\
\text { Waste Alpha-Emitters } \\
\text { for 5- } \mu \text { AMAD }(\mathrm{Sv} / \mathrm{Bq})\end{array}$ & $\begin{array}{c}\text { Effective DCF from } \\
\text { ICRP-68 for Tank } \\
\text { Waste Alpha-Emitters } \\
\text { for } 1-\mu \text { AMAD } \\
(\mathrm{Sv} / \mathrm{Bq})\end{array}$ & $\begin{array}{c}\text { Effective DCF from } \\
\text { ICRP-71 } \\
\text { Ador Dose to } \\
\text { Adults from Tank Waste } \\
\text { Alpha-Emitters } \\
(\mathrm{Sv} / \mathrm{Bq})\end{array}$ \\
\hline $\begin{array}{l}\text { Single-shell } \\
\text { tank liquids }\end{array}$ & $2.92 \mathrm{E}-0.5$ & $4.26 \mathrm{E}-05$ & $4.56 \mathrm{E}-0.5$ \\
\hline $\begin{array}{l}\text { Single-shell } \\
\text { tank solids }\end{array}$ & $2.97 \mathrm{E}-05$ & $4.32 \mathrm{E}-05$ & $4.61 \mathrm{E}-0.5$ \\
\hline $\begin{array}{l}\text { Double-shell } \\
\text { tank liquids }\end{array}$ & $2.79 \mathrm{E}-05$ & $4.04 \mathrm{E}-05$ & $4.34 \mathrm{E}-05$ \\
\hline $\begin{array}{l}\text { Double-shell } \\
\text { tank solids }\end{array}$ & $2.88 \mathrm{E}-05$ & $4.19 \mathrm{E}-05$ & $4.49 \mathrm{E}-05$ \\
\hline Average & $2.90 \mathrm{E}-05$ & $4.20 \mathrm{E}-05$ & $4.50 \mathrm{E}-05$ \\
\hline
\end{tabular}

Note: The average alpha DCl computed based on super-lank data will be used to calculate doses based on gross alpha activities.

"ICRP-68, 1994, Dose Coefficients for Intakes of Radionuclides by Workers-Replacement of ICRP Publication 61, Annals of the International Commission on Radiation Protection, Volume 24, Number 4, Elsevier Science, Tarrytown, New York.

"ICRP-71, 1995, Age Dependent Doses to Members of the Public from Intake of Radionuclides Part 4 Inhalation Dose Coefficients, Annats of the International Commission on Radiation Protection, Volume 25, Number 3-4, Elsevier Science. Tarrytown, New York.

$\mathrm{AMAD}=$ activity median aerodynamic diameter. $\mathrm{DCF}=$ dose conversion factor. 


\subsection{TANK CHARACTERIZATION DATA AND UNIT LITER DOSE MODELS}

This section describes the development of ULDs. Section 4.1 is a brief description of the initial development of ULDs for the tank farms. Section 4.2 describes the data and statistical methods used to develop the ULDs presented in this report. Section 4.2 recommends that the 95 th percentile values taken from a lognormal distribution of mean ULDs calculated for cach tank model be used as the ULDs for consequence calculations. Section 4.3 presents an evaluation of whether the subset of data used to calculate ULDS is representative of the entire data set. Section 4.4 provides guidance and examples for development of tank-specific or subset ULDs.

The ULDs presented in Tables 4-1 through 4-3 should be used for accident analysis. Except for the ULD given for tank 241-AZ-101, the ULDs are based on the 95th percentile of the lognormal distributions fit to the mean for each tank ULD value shown in Figures 4-1 through 4-8. The ULDs given for tank 241-AZ-101 are taken from WHC-SD-WM-SARR-016. The ULDs for tank 241-AZ-101 will be recalculated when samples taken from that tank have been analyzed.

Table 4-1. Inhalation Unit Liter Doses for Onsite Receptor, 95th Percentile.

\begin{tabular}{|c|c|c|c|}
\hline $\begin{array}{c}\text { SST Solids } \\
(\mathbf{S v} / \mathbf{L})\end{array}$ & $\begin{array}{c}\text { SST Liquids } \\
(\mathbf{S v} / \mathbf{L})\end{array}$ & $\begin{array}{c}\text { DST Solids } \\
\mathbf{( S v / L )}\end{array}$ & $\begin{array}{c}\text { DST Liquids } \\
\mathbf{( S v} / \mathbf{L})\end{array}$ \\
\hline & & & \\
\hline $1.06 \mathrm{E}+04$ & $1.44 \mathrm{E}+03$ & $1.07 \mathrm{E}+05$ & $7.97 \mathrm{E}+02$ \\
\hline
\end{tabular}

Note: ULDs in this table are calculated based on the methodology in ICRP-68, 1994. Dose' C'ocfficients for Intakes of Radionuclides by Workers -Replacement of ICRP Publication 6I, Annals of the International Commission on Radiation Protection, Volume 24, Number 4, Elsevier Science, Tarrytown, New York.

DST -- double-shell lank.

SS' '. single-shell tank.

Table 4-2. Total Unit Liter Dose for Accident Analysis for the Public, 95th Percentile.

\begin{tabular}{|c|c|c|c|}
\hline $\begin{array}{c}\text { SST Solids } \\
(\mathbf{S v} / \mathbf{L})\end{array}$ & $\begin{array}{c}\text { SST Liquids } \\
(\mathbf{S v} / \mathbf{L})\end{array}$ & $\begin{array}{c}\text { DST Solids } \\
(\mathbf{S v} / \mathbf{L})\end{array}$ & $\begin{array}{c}\text { DST Liquids } \\
(\mathbf{S v} / \mathbf{L})\end{array}$ \\
\hline $1.66 \mathrm{E}+04$ & $1.28 \mathrm{E}+03$ & $1.84 \mathrm{E}+05$ & $8.45 \mathrm{E}+02$ \\
\hline
\end{tabular}

DST = double-shell tank.

SST $\therefore$ single-shell tank. 
Table 4-3. Inhalation and Ingestion Unit Liter Doses for Tank 241-AZ-101 Accident Analyses.

\begin{tabular}{|c|c|c|c|}
\hline \multicolumn{2}{|c|}{$\begin{array}{c}\text { Inhalation } \\
(\mathrm{S} v / L)\end{array}$} & \multicolumn{2}{|c|}{$\begin{array}{l}\text { Ingestion } \\
\left(\mathbf{S v}-\mathbf{m}^{\mathbf{3}} / \mathrm{L}-\mathbf{s}\right)\end{array}$} \\
\hline Solid & Liquid & Solid & Liquid \\
\hline $1.76 \mathrm{E}+06$ & $1.43 E+03$ & 8.1 & 0.09 \\
\hline
\end{tabular}

Note: The unit liter doses in this table are based on Aging Waste Facility information from WHC-SD-WM-SARR-016, 1996, Tank Waste Compositions and Atmospheric Dispersion Coefficients for Use in Safety Analysis Consequence Assessments, Rev. 2, Fluor Daniel Northwest, Richland, Washington.

Ground shine is not included in the onsite inhalation pathway because ground shine is a slow-todevelop dose pathway, which produces relatively low dose rates, and is not an immediate threat to personnel. Ground shine will be mitigated by either evacuation and posting of contaminated areas or decontamination of the areas. Shine from pools formed from liquid leaks is included in the accident evaluations but not included in the ULDs because this dose varies depending on the accident scenario. The calculation notes specific to leak or spill scenarios should be consulted for details of the pool shine calculations. Ground shine is included for completeness in the 24-hour ingestion dose although it is a relatively small contributor $(<0.1$ percent).

The inhalation ULDs calculated using ICRP-68 are to be used for calculating doses to the onsite $(100 \mathrm{~m})$ worker. The inhalation ULDs calculated using ICRP-7I and ICRP-72 are to be used for calculating doses to the public. The ingestion and ground shine dose to the public is estimated to be bounded by 10 percent of the inhalation dose (see Section B8.0). The total ULDs (inhalation, ingestion, and shine) for calculating dose to the public are given in Table 4-2.

\subsection{ORIGINAL (SUPER-TANK) UNIT LITER DOSE MODEL}

The ULDs used in the FSAR (HNF-SD-WM-SAR-067) were based on a super-tank model. Six models were used, one each for SST solids, SST liquids, DST solids, DST liquids, AWF solids, and AWF liquids. The 11 radionuclides listed in Tables 2-2, 2-3, and 2-4 were used in the supertank models. The highest verified concentration of each radionuclide in each group of tanks was found. These concentrations were then assumed to be in one tank, the "super tank," and a ULD was calculated. In this case, verified means that the sample results were examined to see that there were no calculation errors in the laboratory report, no physical laws were broken (i.e., solubility), and process history did not make such a result impossible. In addition, both pre-1989 and post-1989 sample data were used in the source terms even though the Hanford Federal Facility Agreement and Consent Order (Tri-Party Agreement 1990) stipulates that post-1989 sample data are to be used for activities covered by the Tri-Party Agreement. The pre-1989 data were used because post-1989 data were not available for a number of tanks. It was believed, and DOE concurred, that it was better to use pre-1989 data than no data. 
In Fcbruary 1999, LMHC's Process Control organization distributed Interoffice Memorandum 74B50-99-013, Assessment of Radionuclide Data Since 1995 Against the Source Term (Reynolds 1999). The assessment compared the data generated by the characterization program since 1995 with the data used to generate the ULDs in the FSAR (HNF-SD-WM-SAR-067). The report identifies new bounding concentrations for some radionuclides. Table 4-4, reproduced from Interoffice Mcmorandum 74B50-99-()13 (Reynolds 1999), shows the new bounding concentrations.

Table 4-4. Bounding Concentrations.

\begin{tabular}{|l|l|c|c|}
\hline \multicolumn{1}{|c|}{ Radionuclide } & \multicolumn{1}{|c|}{ Tank Type and State } & \multicolumn{1}{|c|}{$\begin{array}{c}\text { Revised Limit } \\
(\mathbf{B q} / \mathbf{L})\end{array}$} & \multicolumn{1}{|c|}{$\begin{array}{c}\text { FSAR* Limit } \\
(\mathbf{B q} / \mathbf{L})\end{array}$} \\
\hline${ }^{60} \mathrm{Co}$ & Aging waste liquids & $1.12 \mathrm{E}+06$ & $7.71 \mathrm{E}+05$ \\
\hline${ }^{100} \mathrm{Sr}-{ }^{90} \mathrm{Y}$ & Single-shell solids & $3.27 \mathrm{E}+12$ & $1.6 \mathrm{E}+12$ \\
\hline${ }^{237} \mathrm{~Np}$ & Single-shell solids & $8.17 \mathrm{E}+07$ & $3.0 \mathrm{E}+07$ \\
\hline${ }^{238} \mathrm{Pu}$ & Aging waste liquids & $4.22 \mathrm{E}+05$ & $2.75 \mathrm{E}+03$ \\
\hline${ }^{239} \mathrm{Pu}$ & Single-shell solids & $1.2 \mathrm{E}+09$ & $4.4 \mathrm{E}+08$ \\
\hline${ }^{239} \mathrm{Pu}$ & Aging waste liquids & $2.33 \mathrm{E}+06$ & $1.20 \mathrm{E}+06$ \\
\hline${ }^{241} \mathrm{Am}$ & Single-shell solids & $2.59 \mathrm{E}+09$ & $2.3 \mathrm{E}+08$ \\
\hline${ }^{241} \mathrm{Am}$ & Double-shell solids & $6.21 \mathrm{E}+09$ & $2.7 \mathrm{E}+09$ \\
\hline
\end{tabular}

*HNF-SD-WM-SAR-067, 2000, Tank Waste Remediation System Final Safety Analysis Report, Rev. II), lockheed Martin Ilanford Corporation, Richland, Washington.

New ULDs were calculated based on the values shown in Table 4-4. The calculational method was the same as that used in the FSAR (HNF-SD-WM-SAR-067). The highest concentrations for each radionuclide were assumed to be in a single tank, and a ULD was calculated. The new ULDs, the FSAR ULDs, and a ratio of new-to-FSAR ULDs are shown in Table 4-5, which is also taken from Interoffice Memorandum 74B50-99-013 (Reynolds 1999).

As was cxpected, an increase in concentration of one (or more) of the radionuclides used to calculate the ULD results in an increase in the ULD. Each radionuclide has a different effect on the calculated ULDs. Therefore the magnitude of the increase in the ULD depends on which radionuclide concentrations increase. In this case, two of the radionuclides that have a large effect on the ULDs, ${ }^{2+1} \mathrm{Am}$ and ${ }^{239} \mathrm{Pu}$, had significant increases in concentration. Significant increases in the ULDs for SST solids and DST solids resulted.

If the super-tank methodology continues to be used, the source term ULD will have to be adjusted and accident consequences recalculated every time a radionuclide analysis is found that exceeds the one used in the FSAR (HNF-SD-WM-SAR-067). Continuing the current system will result in statistically insignificant outliers driving the calculation of the ULD. The current super-tank model only counts high values, so there will be a constant upward creep in the ULDs. 
Table 4-5. Comparison of Bounding Concentrations.

\begin{tabular}{|l|c|c|c|}
\hline \multicolumn{1}{|c|}{ Composite } & $\begin{array}{c}\text { Revised Inhalation } \\
\text { ULD } \\
\text { (Sv/L) }\end{array}$ & $\begin{array}{c}\text { FSAR* Inhalation } \\
\text { ULD } \\
\text { (Sv/L) }\end{array}$ & $\begin{array}{c}\text { Revised ULD/ } \\
\text { FSAR* ULD }\end{array}$ \\
\hline Single-shell tank liquid & $1.08 \mathrm{E}+04$ & $1.10 \mathrm{E}+04$ & 0.98 \\
\hline Single-shell tank solids & $7.10 \mathrm{E}+05$ & $2.21 \mathrm{E}+05$ & 3.21 \\
\hline Double-shell tank liquids & $6.00 \mathrm{E}+03$ & $6.06 \mathrm{E}+03$ & 0.99 \\
\hline Double-shell tank solids & $9.47 \mathrm{E}+05$ & $5.29 \mathrm{E}+05$ & 1.79 \\
\hline Aging Waste Facility liquids & $1.55 \mathrm{E}+03$ & $1.42 \mathrm{E}+03$ & 1.09 \\
\hline Aging Waste Facility solids & $1.71 \mathrm{E}+06$ & $1.73 \mathrm{E}+06$ & 0.99 \\
\hline All liquids & $1.16 \mathrm{E}+04$ & $1.17 \mathrm{E}+04$ & 0.99 \\
\hline All solids & $1.89 \mathrm{E}+06$ & $1.87 \mathrm{E}+06$ & 1.01 \\
\hline
\end{tabular}

*IINF-SI)-WM-SAR-067, 2000, Tank Waste Remediation System Final Safety Analisis Report, Rev. 1D, Lockheed Martin Hanford Corporation, Richland. Washington.

FSAR -- final safety analysis report.

ULD - unit liter dose.

\subsection{MODEL USING STATISTICAI. TREATMENT OF NEW CHARACTERIZATION DATA}

The sample data used for this work were taken from the Tank Characterization Database (TCD) (PNNL 1999). The statistical analysis of the data is explained in HNF-4534. Sample Based Unit Liter Dose Estimates, which is reproduced as Appendix $C$ in this document. A brief description of the method is given in this section. The proposed methodology calculates a mean ULD for each tank that has sample data for ${ }^{87 / \%} \mathrm{Sr}\left(\right.$ or $\left.^{90} \mathrm{Y}\right),{ }^{137} \mathrm{Cs}$, and gross alpha. The activity concentrations for ${ }^{90} \mathrm{Sr}$ and ${ }^{9 \%} \mathrm{Y}$ are the same, so the concentration of ${ }^{90} \mathrm{Y}$ can be inferred from the ${ }^{81 / \% 0} \mathrm{Sr}$ data. The gross alpha component includes ${ }^{2+1} \mathrm{Am},{ }^{238} \mathrm{Pu},{ }^{231} \mathrm{Pu},{ }^{237} \mathrm{~Np}$, and ${ }^{244} \mathrm{Cm}$. The specified radionuclides and gross alpha activity account for a minimum of 92 percent (refer to Table 2-5) of the inhalation and ingestion doses from the waste in the tanks (Brevick 200(0). Section 3.5 explains the calculation of DCFs for all the alpha-emitting isotopes. This DCF can therefore be used with the gross alpha activity in the same way as the DCFs for specific activity. The concentration data are therefore available, or can be inferred, for ${ }^{60} \mathrm{Sr},{ }^{96} \mathrm{Y},{ }^{137} \mathrm{Cs}$, and gross alpha. The three measured analytes actually result in eight radioisotopes being used to calculate the ULDs. All 8 were included in the total of 11 radionuclides used in the FSAR (HNF-SD-WM-SAR-067).

With this methodology, individual tank mean ULDs could be compared with the FSAR ULDs. A tank could be found to have an analyte that exceeds the value previously used as "bounding," but as long as the mean ULD for that tank did not exceed the FSAR ULD, operations would not be affected. 
The radionuclide concentrations used to calculate the tank-specific ULDs are mean values of the concentrations from each tank. The mean ULDs are used to construct a distribution of ULDs (see Figures 4-1 through 4-8). Three different distributions, lognormal, gamma and Weibull, were tried. The lognormal distribution was the only distribution that was not rejected using "goodness-of-fit" criteria. From the distribution of ULDs, values are selected (i.e., the quantile associated with the 90th, 95th, or 99th percentile value) depending on the level of conservatism determined to be appropriate. The ULDs selected using this process are ULDs that exceed the selected quantile of the values in the population. That is, for the 95th percentile ULD, approximately 1 in 20 tanks will have ULDs exceeding the selected value. No confidence statements are attached to these estimates.

Tolerance limits can also be used to select ULDs. This approach makes a confidence statement regarding the proportion of the population that has a ULD limit less than a specified value. Given the distributions of ULDs shown in Figures 4-1 through 4-8, tolerance limits predict the probability that a selected ULD number will not be exceeded and attaches a confidence statement to the prediction. The method depends on the number of tanks that are sampled. Using SST solids as an example, where 54 of 149 tanks have the required sample information, the 95/95 tolerance limit says there is 95 percent confidence that 95 percent of the population is less than the given limit or ULD value. In other words, there is a 95 percent confidence level that no more than 1 in 20 tanks will exceed the given ULD.

Figures 4-1 through 4-8 are histograms of the lognormal distribution of the number of tanks sampled for each of the waste types versus the mean ULD in sieverts per liter. Superimposed on each plot are the 95th and 99th percentile ULDs, the 95/95 and 95/99 tolerance limit ULDs, and the current FSAR ULDs. The plots are for SST solids and liquids and DST solids and liquids using the DCFs from ICRP-68, ICRP-71, and ICRP-72.

The DST plots include tanks 241-AY-101, 241-AY-102, and 241-AZ-102. In the FSAR (HNF-SD-WM-SAR-067), the 241-AY and 241-AZ tanks are included in the AWF tank grouping. A review of the contents of the 241-AY tanks and 241-AZ-102 led to the conclusion that it was more logical to place these tanks in the DST grouping. The only remaining tank in the AWF tank group is 241-AZ-101. The 241-AZ tanks were sampled during the fourth quarter of calendar year 1999. Preliminary sample analyses place 241-AZ-102 in the DST category. Complete sample results are not yet available for 241-AZ-101. Sample results for 241-AZ-101 liquid are included in Figures 4-4 and 4-8. However, information on 241-AZ-101 solids is not yet available. Until the sample results for 241-AZ-101 are available, the FSAR ULDs for AWF tanks (HNF-SD-WM-SAR-067) should be used for 241-AZ-101.

Table 4-6 summarizes the ULD numerical values from Figures 4-1 through 4-8 by percentile and tolerance limit, and includes the ULDs used in the FSAR (HNF-SD-WM-SAR-067). 
Table 4-6. Summary of Unit Liter Doses by Percentile and Tolerance Limit.

\begin{tabular}{|c|c|c|c|c|c|c|c|c|}
\hline \multirow[t]{2}{*}{ ULD Type } & \multicolumn{2}{|c|}{$\begin{array}{c}\text { SST Solids } \\
(\mathrm{Sv} / \mathrm{L})\end{array}$} & \multicolumn{2}{|c|}{$\begin{array}{c}\text { DST Solids } \\
(\mathrm{Sv} / \mathrm{L})\end{array}$} & \multicolumn{2}{|c|}{$\begin{array}{c}\text { SST Liquids } \\
(\mathrm{Sv} / \mathrm{L})\end{array}$} & \multicolumn{2}{|c|}{$\begin{array}{l}\text { DST Liquids } \\
\text { (Sv/L) }\end{array}$} \\
\hline & ICRP-68 & ICRP-71 & ICRP-68 & ICRP-71 & ICRP-68 & ICRP-71 & ICRP-68 & ICRP-71 \\
\hline 95th pereentile & $1.06 \mathrm{E}+4$ & $1.51 \mathrm{E}+4$ & $1.07 \mathrm{~F}+5$ & $1.67 \mathrm{E}+5$ & $1.44 \mathrm{li}+3$ & $1.16 \mathrm{E}+3$ & $7.97 \mathrm{E}+2$ & $7.68 \mathrm{E}+2$ \\
\hline $95 / 95$ tolerance limit & $2.06 \mathrm{E}: 4$ & $2.99 \mathrm{E} \vdash 4$ & $8.82 E+5$ & $1.51 \mathrm{E}+6$ & $5.04[\mathrm{E}+3$ & $3.89 \mathrm{E}+3$ & $2.33 \mathrm{E}+3$ & $2.31 \mathrm{E}+3$ \\
\hline 99th percentile & $3.26 \mathrm{E}+4$ & $4.77 \mathrm{I}+4$ & $5.09 \mathrm{E}+5$ & $8.53 \mathrm{E}+5$ & $5.01 \mathrm{E}+3$ & $3.88 E+3$ & $2.53 E+3$ & $2.51 \mathrm{E}+3$ \\
\hline $\begin{array}{l}\text { Final Safety Analysis } \\
\text { Report }\end{array}$ & \multicolumn{2}{|c|}{$2.2 \mathrm{E}+5$} & \multicolumn{2}{|c|}{$5.3 \mathrm{E}+5$} & \multicolumn{2}{|c|}{$1.1 \mathrm{E}+4$} & \multicolumn{2}{|c|}{$6.1 \mathrm{1}+3$} \\
\hline $95 / 99$ tolerance limit & $7.63 \mathrm{E}+4$ & $1.14 \mathrm{E}+5$ & $7.84 \mathrm{E}+6$ & $1.49 \mathrm{E}+7$ & $2.51 \mathrm{j}+4$ & $1.84 \mathrm{E}+4$ & $1.0 \mathrm{E}+4$ & $1.03 E+4$ \\
\hline
\end{tabular}

Note: ILDs are calculated for workers using the dose conversion factors from ICRP-68, 1994, Dose' Cocfficient for Intakes of Radionuclides by Workers. Replacement of /CRP Publication 6/, Annals of the International Commission on Radiation Protection, Volume 24, Number 4, Elsevier Science, Iarrytown, New York. ULDs for offsite receptors are calculated using the dose conversion factors from ICRP-71, 1995, Age Dependent Doses to Members of the Public from Intake of Radionuclides Part 4 Inhalation Dose Coefficients, Annals of the International Commission on Radiation Protection, Volume 25, Number 3-4, Elsevier Science, Tarrytown, New York.

ISST -.. double-shell tank.

SST -- single-shell tank.

ULD = unit liter dose. 


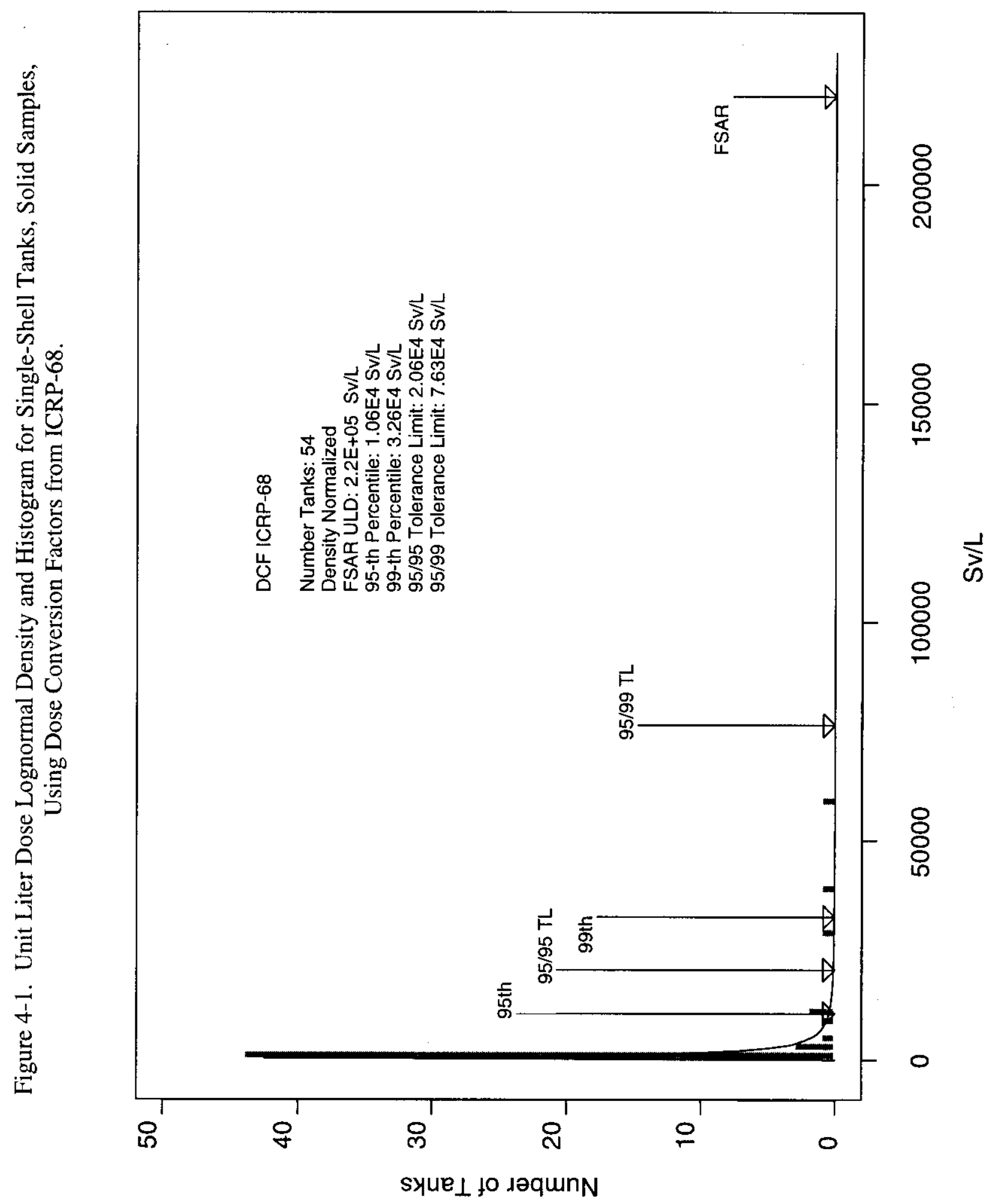




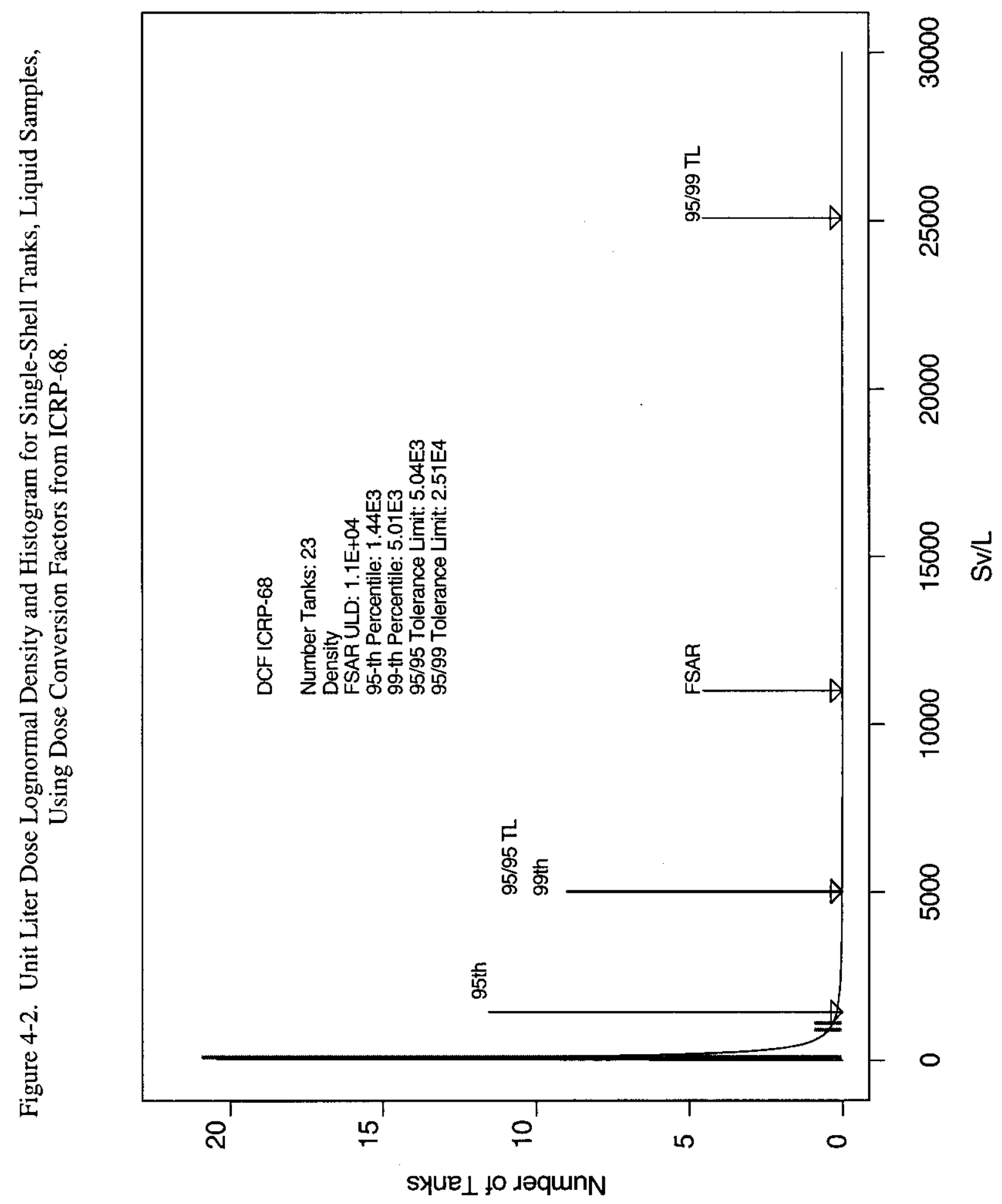




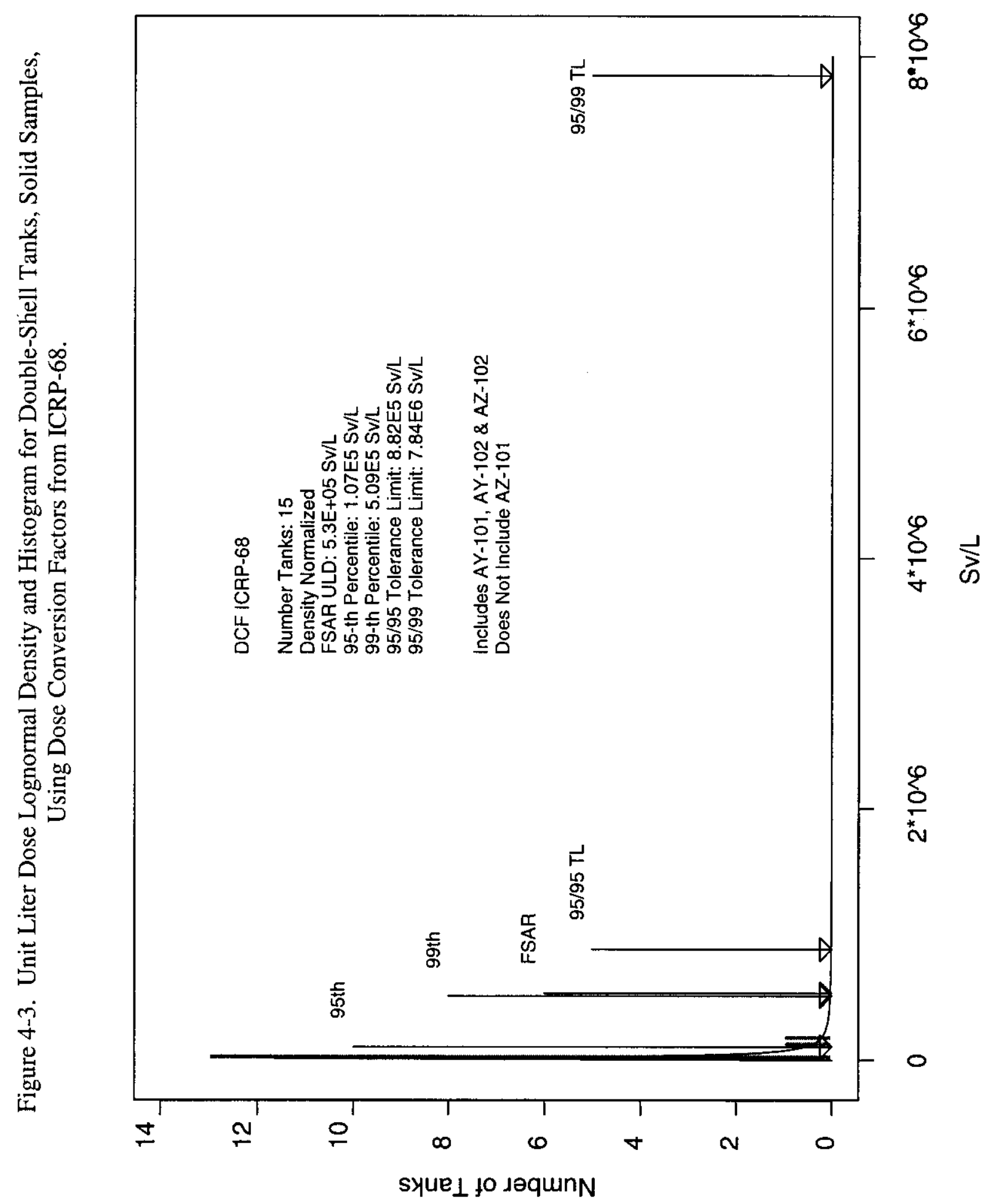




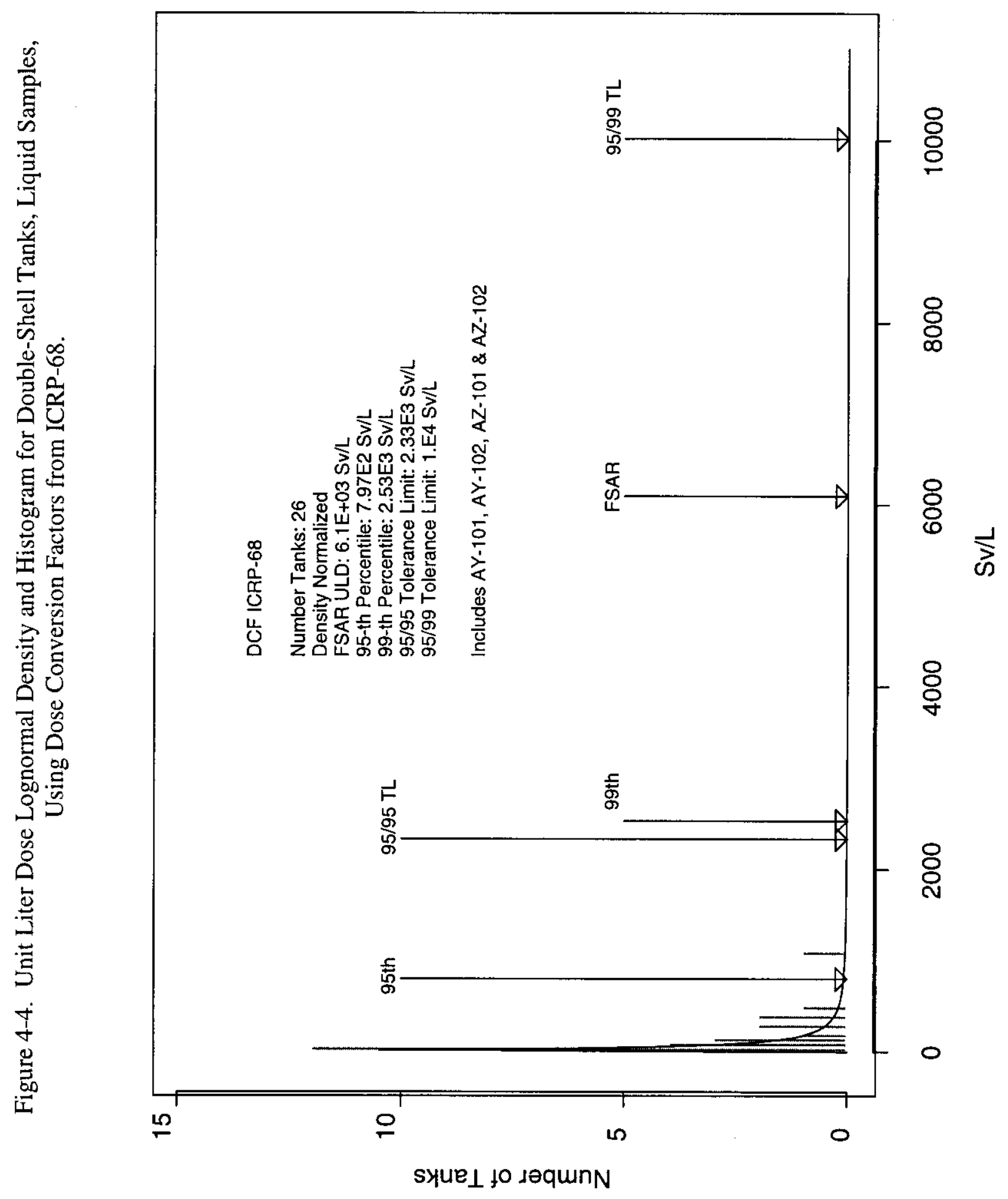


RPP-5924 REV 0

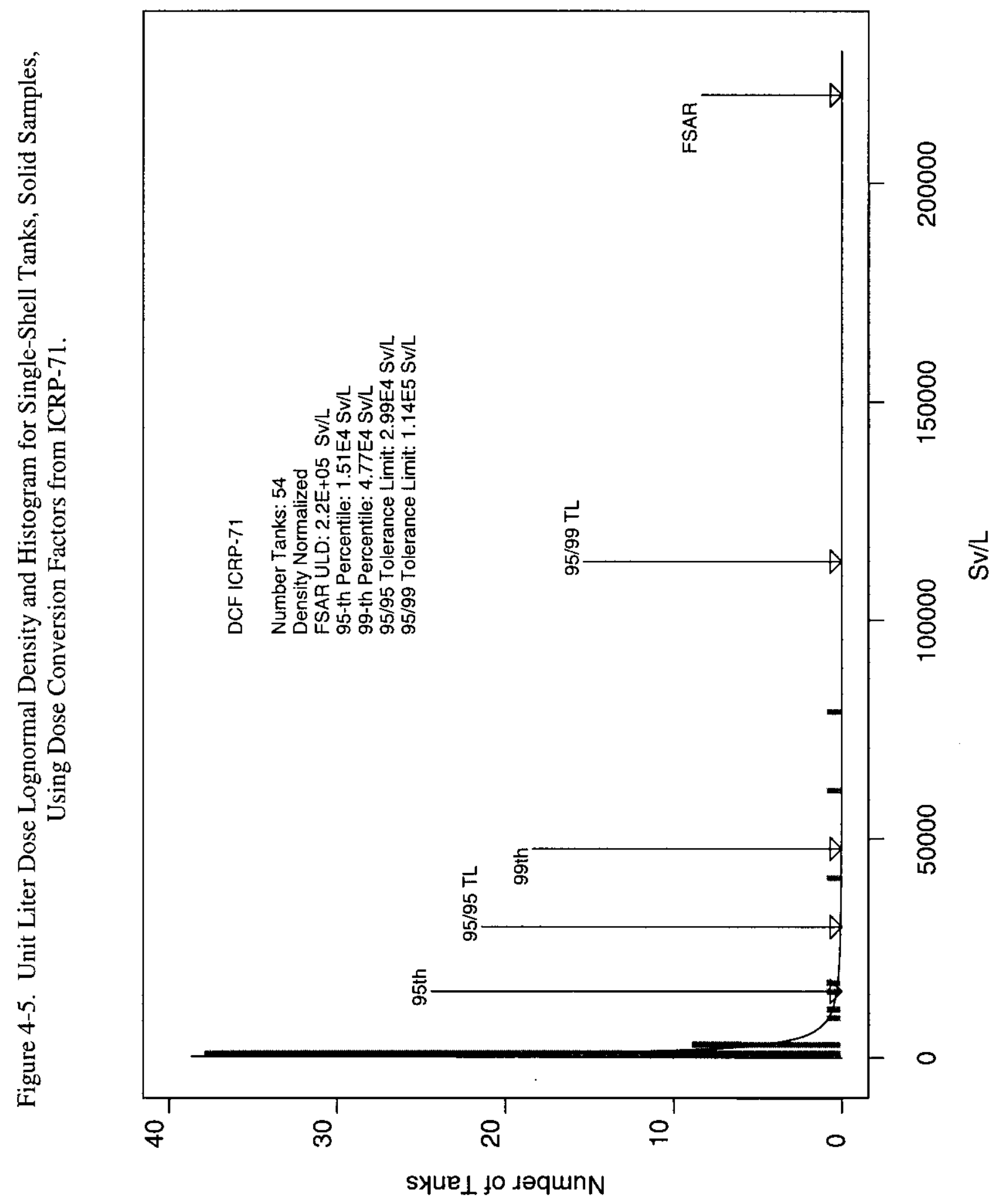


RPP-5924 REV 0

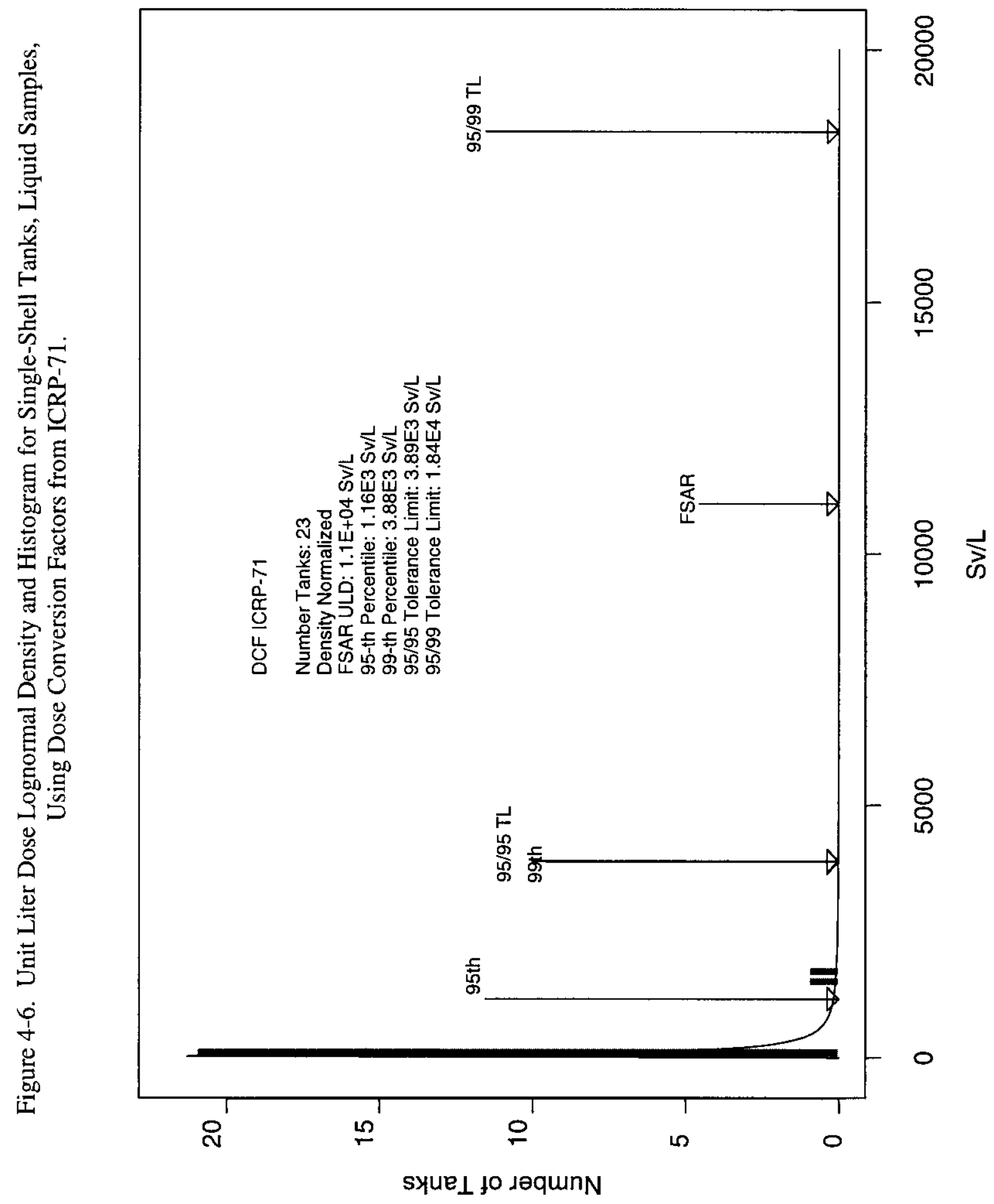




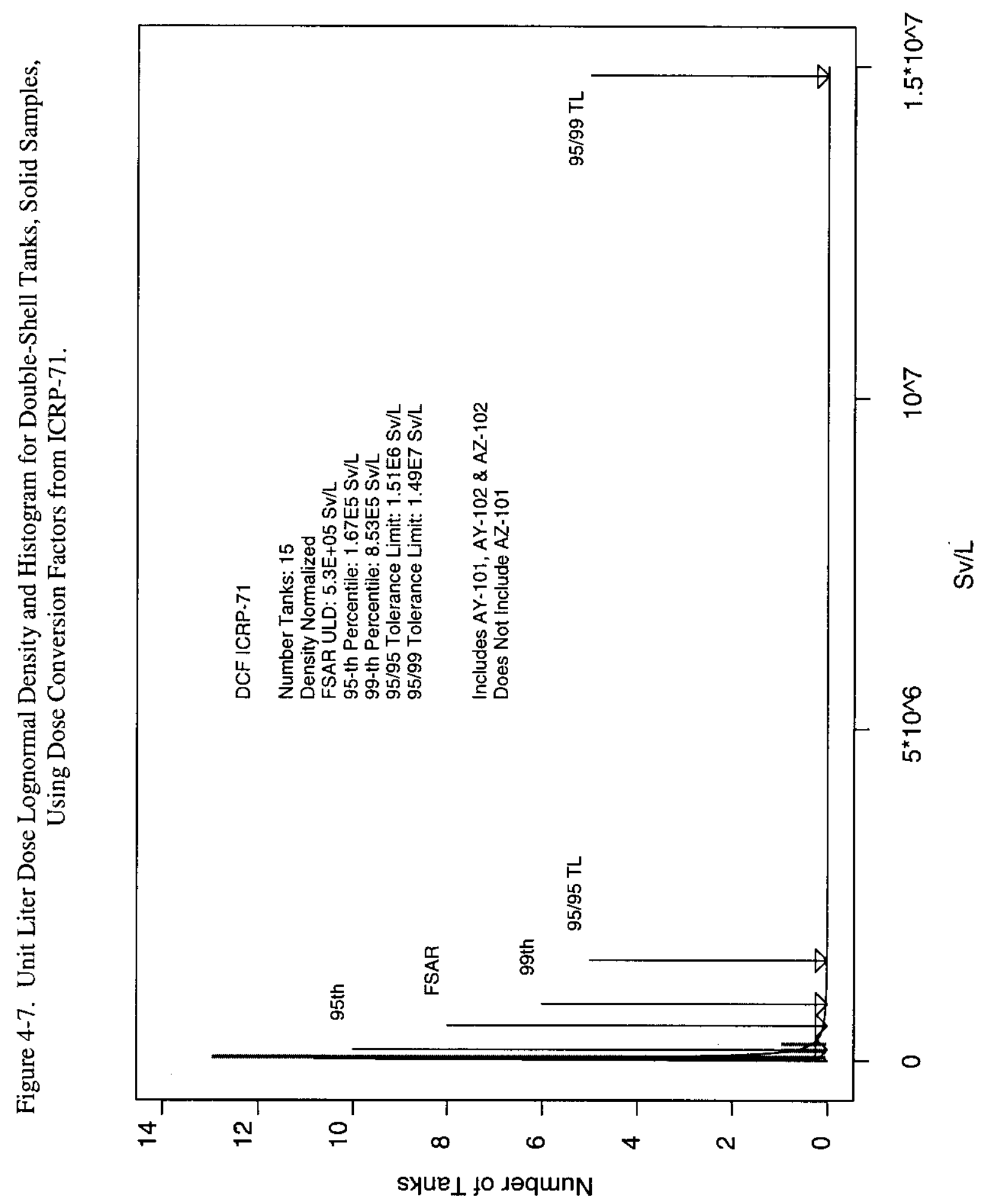




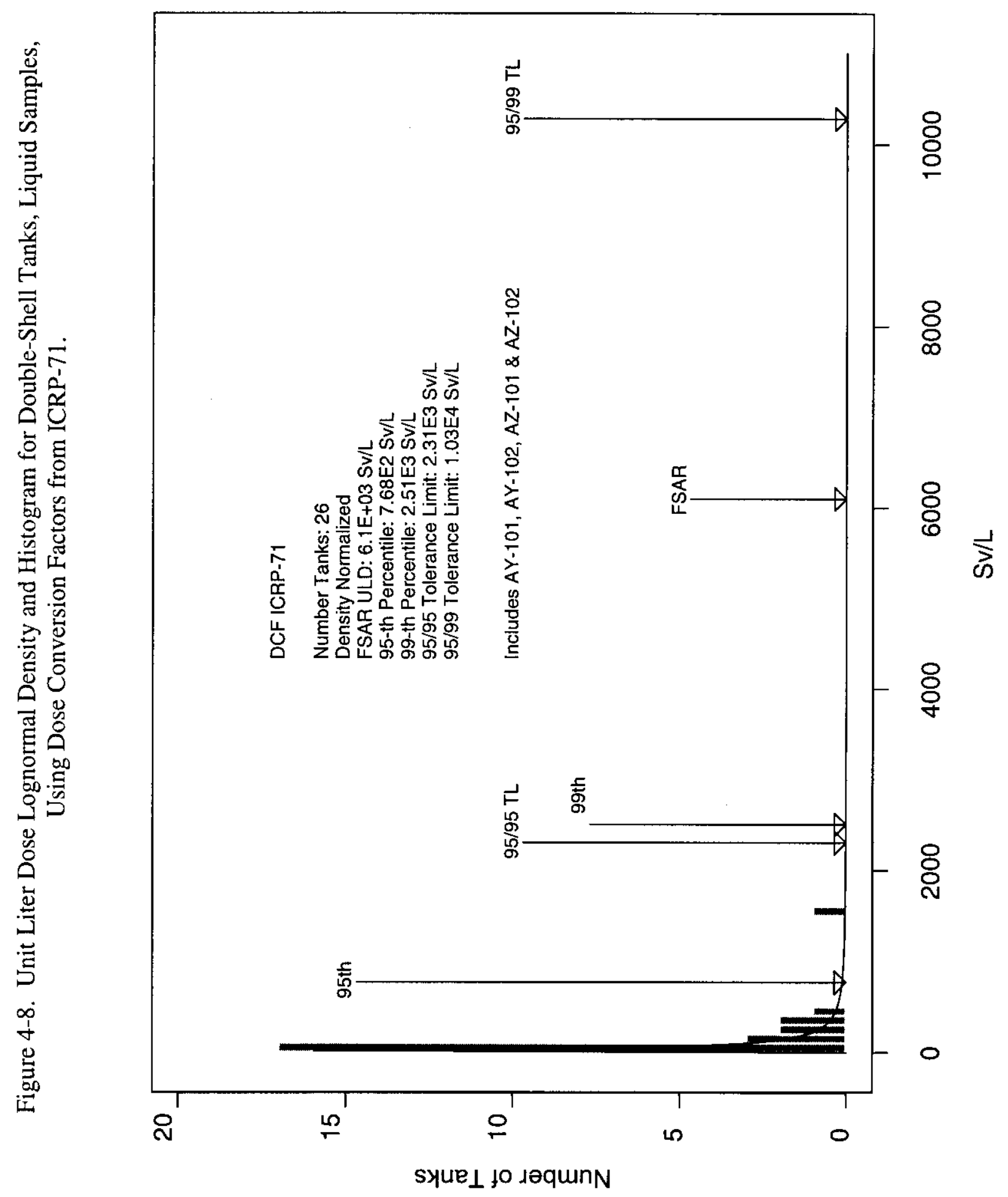




\subsection{REPRESENTATIVENESS OF DATA SET}

This section evaluates the representativeness of the sample distributions in two different ways. The first way compares the subset of sample data used to calculate ULD distributions with the entire set of available sample data. The second determines the effects of using three different models for evaluating sample data reported as "below detection limits." The complete set of calculations and assumptions used in this section is given in HNF-4534, which is reproduced as Appendix C in this document.

Computing a ULD for a tank requires sample data for ${ }^{137} \mathrm{Cs}$, alpha, and ${ }^{90} \mathrm{Sr}$. Many tanks have sample data for at least one of these radionuclides, but ULDs were calculated only for tanks having data on all three radionuclides. Three statistical comparisons can be made between the sets of data. The computer program S-PLUS (S-PLUS 2000) was used to make the following comparisons:

- A comparison of the two variances using an F-test

- A comparison of the two means using a T-test

- A comparison of the two distributions using the two sample KolmogorovSmirnov test.

The F-test was used to test the equality of variances for each of the three radionuclides, for each type of tank (DST and SST), and for each waste phase (solid and liquid). The results of the F-tests show that the variances are not significantly different from each other.

The T-test, assuming equal variances, was used to test the equality of means for each of the three radionuclides, for each type of tank (DST and SST), and for each waste phase (solid and liquid). The results of the T-tests show that the means are not significantly different from each other.

The two sample Kolmogorov-Smirnov test was used to test the equality of distributions for each of the three radionuclides, for each type of tank (DST and SST), and for each waste phase (solid and liquid). The results of the tests show that the two distributions are not significantly different from each other.

All tests were performed at the 0.05 level of significance. A total of 12 combinations ( 2 tank types times 2 phases per tank type times 3 analytes) were evaluated. Two plots, Figures 4-9 and 4-10, are included as examples. Both plots are quantile plots of two sets of data by radionuclide and by waste type. The number of points is the number of tanks with data. The $x$-axis represents the quantiles (i.e., the ordered values of the data). The $y$-axis represents the percentile points (i.e., the point 0.50 corresponds to the median and the point 0.95 corresponds to the quantile for the 95 th percentile). These figures demonstrate that there is little difference between the complete data set and the subset used to calculate the ULDs. A complete table of the numerical results is found in Appendix C of HNF-4534 (see Appendix C of this document). 
RPP-5924 REV 0

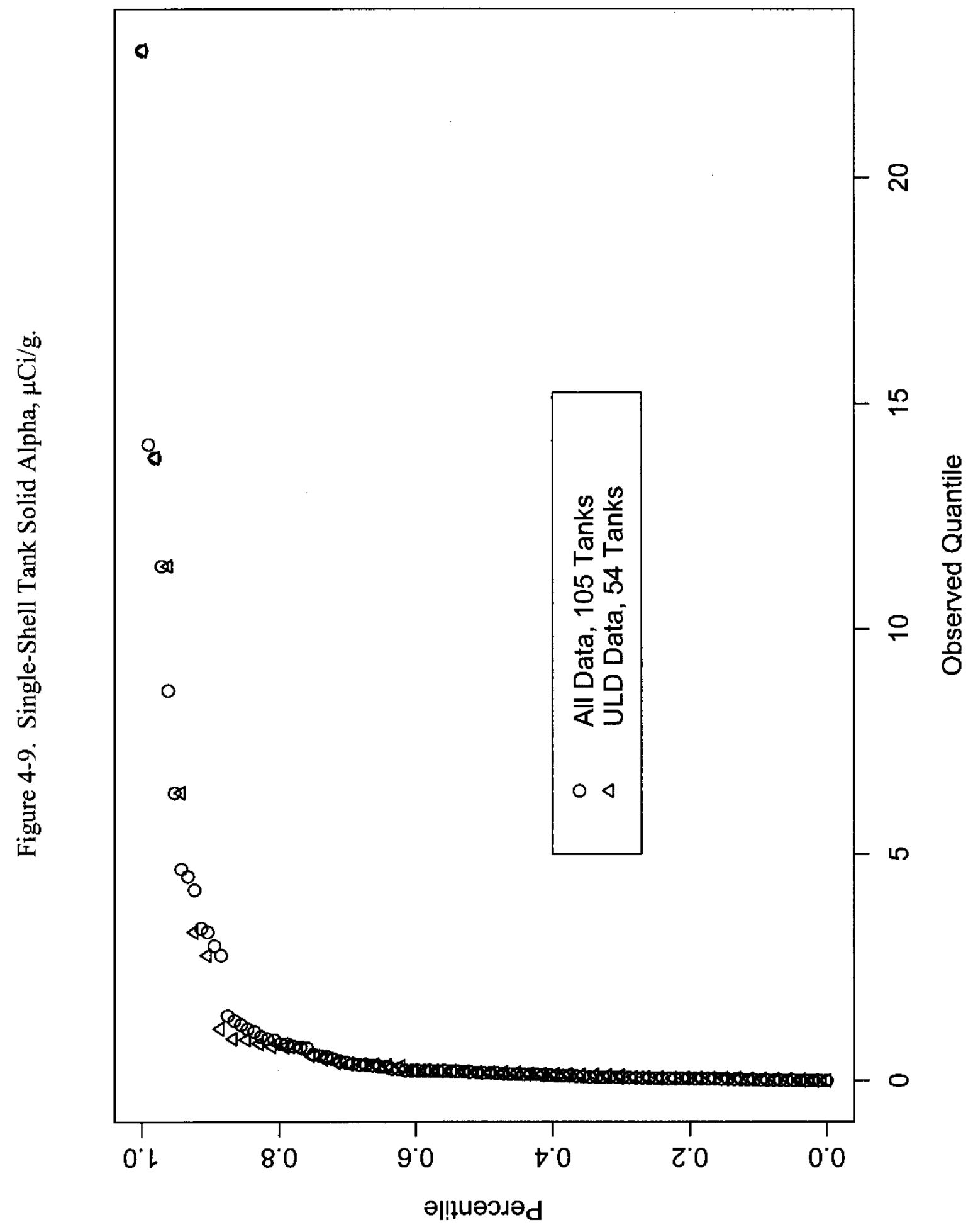


RPP-5924 REV 0

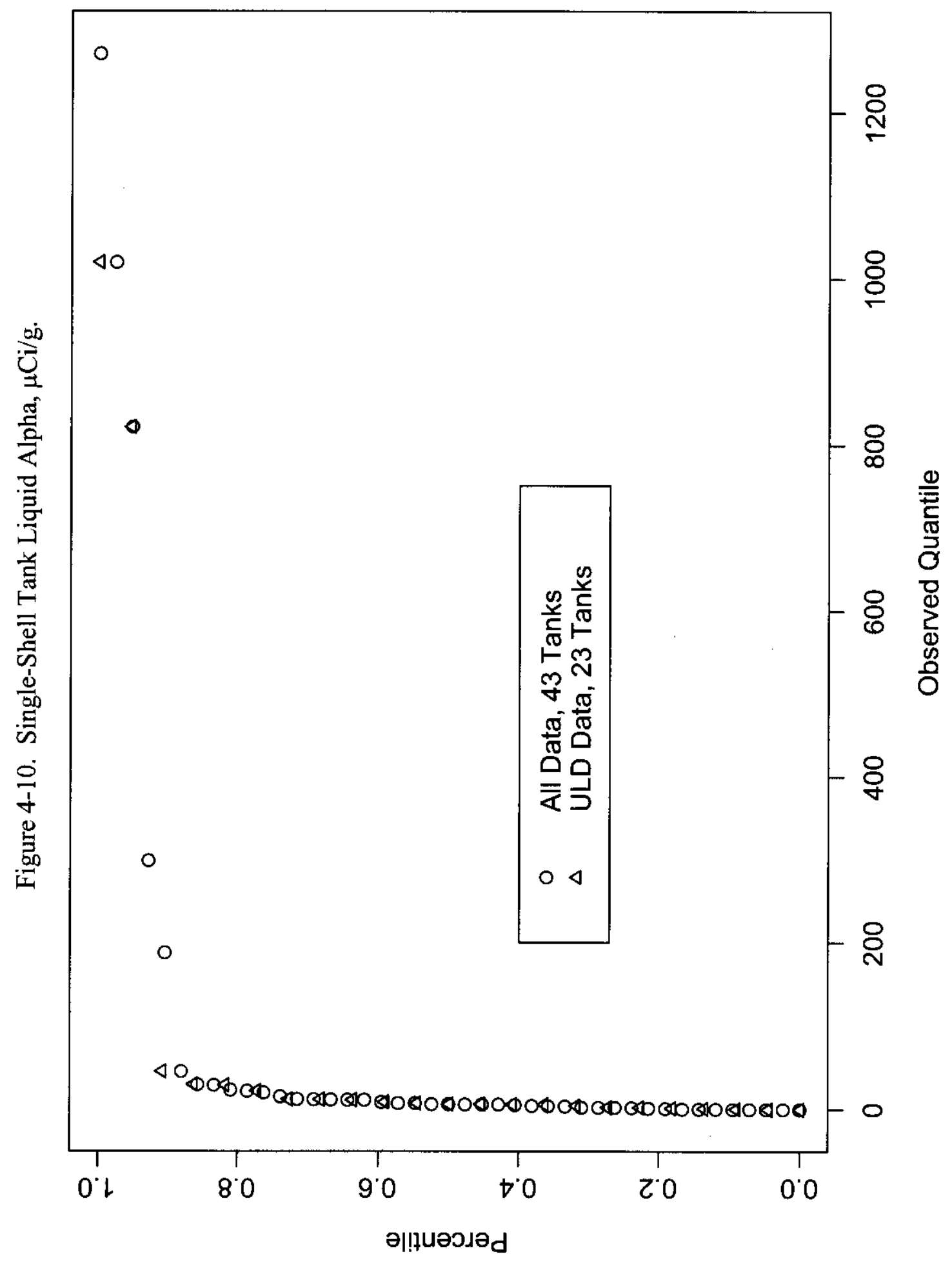


The representativeness of the data set may also be affected by the manner in which data labeled as "below detection limits" are used. The data set used to calculate ULDs intentionally did not use data so marked. Three different models were used to evaluate the observations below the detection limits. In the first model (M1), the observations below the detection limits were omitted; in the second (M2), the observations below the detection limits were replaced by the detection limit; and in the third model (M3), the observations below the detection limits were replaced by zero. The means and variances for each model, by tank type and phase, are shown in Table 4-7, reproduced from Appendix C of HNF-4534 (see Appendix C of this document). The table shows that there is no significant difference in the ULDs using any of the three models for treatment of "below detection limit" data.

\subsection{DEVELOPMENT OF UNIT LITER DOSES FOR SPECIAL CASES AND GROUPS OF TANKS}

As part of the development of the general case ULDs in this report, mean ULDs were calculated for individual tanks for which data on all three analytes were available. The raw data from sampling are available in the TCD (PNNL 1999). The data from the TCD have been sorted and organized and are available in HNF-4534 (see Appendix C of this document). The individual tank ULDs are also in HNF-4534. If the data sets are not limited to the intersection of all three analytes, then additional data are available for each analyte separately. The question of using individual tank ULDs or creating representative ULDs for a subset of tanks is addressed in this section.

Direct use of individual ULDs or of subsets of tank ULDs without developing a rationale or having corroborating information could result in consequence calculations that are either too high or too low for making good control decisions. The basic problem with single tank ULDs is that they can be based on a single sample for one or more of the three analytes. Physically this means that an analysis of one 19 -in.-long by 2 -in.-diameter core segment provides the single value for one of the three radionuclides. A 100 -series waste tank is $75 \mathrm{ft}$ in diameter and may contain waste up to a depth of $20 \mathrm{ft}$ or more. The waste was deposited in the tanks in layers and is not homogenous either vertically or horizontally. Therefore, it is difficult to claim that one sample is representative of the waste in a single tank. Radiological dose calculations that are based on a single sample may overestimate or underestimate the radiological dose by a large factor.

If single tank ULDs or ULDs for subsets of tanks are developed, the accident analyst must carefully evaluate the available data and document the assumptions and methods used to develop the new ULDs. The following information and examples are given as guidance for selecting and using ULDs other than the standard ULDs given in this document.

- The data files for individual radionuclides and tank ULDs can be used in other probability distributions (with justification) or in stochastic analyses where accident parameters are varied using Monte Carlo techniques. An example of a stochastic analysis that uses the data files for individual radionuclides can be found in RPP-5667, Stochastic Consequence Analysis for Waste Leaks. 
Table 4-7. Comparison of Means and Variances of Unit Liter Doses by Waste Type for the Three Models (M1, M2, and M3) for Detection Limits.

\begin{tabular}{|c|c|c|c|c|c|c|}
\hline Model & $\begin{array}{c}\text { Number of } \\
\text { Tanks }\end{array}$ & Mean & Variance & $\begin{array}{c}\text { Number of } \\
\text { Tanks }\end{array}$ & Mean & Variance \\
\hline \multicolumn{7}{|c|}{ DCF for Onsite Receptor from ICRP- $68^{\mathrm{a}}$} \\
\hline & \multicolumn{3}{|c|}{ ULD SST Solid Samples } & \multicolumn{3}{|c|}{ ULD SST Liquid Samples } \\
\hline M1 & 54 & $3.68 \mathrm{E}+03$ & $1.05 \mathrm{E}+08$ & 23 & $1.73 \mathrm{E}+02$ & $7.90 \mathrm{E}+04$ \\
\hline M2 & 57 & $3.41 \mathrm{E}+03$ & $9.44 \mathrm{E}+07$ & 26 & $1.70 \mathrm{E}+02$ & $5.86 \mathrm{E}+04$ \\
\hline \multirow[t]{2}{*}{ M3 } & 57 & $3.39 \mathrm{E}+03$ & $9.45 \mathrm{E}+07$ & 26 & $1.28 \mathrm{E}+02$ & $4.37 \mathrm{E}+04$ \\
\hline & \multicolumn{3}{|c|}{ ULD DST Solid Samples } & \multicolumn{3}{|c|}{ ULD DST Liquid Samples } \\
\hline $\mathrm{Ml}$ & 15 & $2.42 \mathrm{E}+04$ & $2.74 \mathrm{E}+09$ & 26 & $1.48 \mathrm{E}+02$ & $5.35 \mathrm{E}+04$ \\
\hline $\mathrm{M} 2$ & 15 & $2.41 \mathrm{E}+04$ & $2.74 \mathrm{E}+09$ & 27 & $1.41 E+02$ & $5.19 \mathrm{E}+04$ \\
\hline M3 & 15 & $2.41 \mathrm{E}+04$ & $2.74 \mathrm{E}+09$ & 27 & $1.35 \mathrm{E}+02$ & $5.13 \mathrm{E}+04$ \\
\hline \multicolumn{7}{|c|}{ DCF for Offsite Receptor from ICRP-71 ${ }^{\mathrm{b}}$} \\
\hline & \multicolumn{3}{|c|}{ ULD SST Solid Samples } & \multicolumn{3}{|c|}{ ULD SST Liquid Samples } \\
\hline M1 & 54 & $5.19 \mathrm{E}+03$ & $2.08 \mathrm{E}+08$ & 23 & $2.03 \mathrm{E}+02$ & $1.92 \mathrm{E}+05$ \\
\hline $\mathrm{M} 2$ & 57 & $4.80 \mathrm{E}+03$ & $1.84 \mathrm{E}+08$ & 26 & $1.99 \mathrm{E}+02$ & $1.44 \mathrm{E}+05$ \\
\hline \multirow[t]{2}{*}{ M3 } & 57 & $4.77 \mathrm{E}+03$ & $1.84 \mathrm{~F}+08$ & 26 & $1.35 \mathrm{E}+02$ & $1.08 \mathrm{E}+05$ \\
\hline & \multicolumn{3}{|c|}{ ULD DST Solid Samples } & \multicolumn{3}{|c|}{ ULD DST Liquid Samples } \\
\hline M1 & 15 & $3.33 \mathrm{E}+04$ & $4.82 \mathrm{E}+09$ & 26 & $1.57 \mathrm{E}+02$ & $9.82 \mathrm{E}+04$ \\
\hline $\mathrm{M} 2$ & 15 & $3.32 \mathrm{E}+04$ & $4.82 \mathrm{E}+09$ & 27 & $1.49 \mathrm{E}+02$ & $9.48 \mathrm{E}+04$ \\
\hline M3 & 15 & $3.31 E+04$ & $4.83 \mathrm{E}+09$ & 27 & $1.39 \mathrm{E}+02$ & $9.48 \mathrm{E}+04$ \\
\hline
\end{tabular}

${ }^{2}$ ICRP-68, 1994, Dose Coefficients for Intakes of Radionuclides by Workers-Replacement of ICRP

Publication 61, Annals of the International Commission on Radiation Protection. Volume 24, Number 4, Elsevier Science, Tarrytown, New York, New York.

"ICRP-71, 1995, Age Dependent Doses to Members of the Public from Intake of Radionuclides Part 4 Inhalation Dose Coefficients, Annals of the International Commission on Radiation Protection. Volume 25,

Number 3.4, Elsevier Science. 'Tarrylown, New York, New York.

$\mathrm{DCF}=$ dose conversion factor.

DST $=$ double shell tank.

MI = observations below the detection limits were omitted.

M2 = observations below the detection limits were replaced by the detection limit.

M3 = observations below the detection limits were replaced by zero.

SST $=$ single shell tank.

ULD = unit liter dose. 


\section{RPP-5924 REV 0}

- For individual tank ULDs or ULDs for groups of tanks, corroborating information can be used to help establish that ULDs are representative of the tank or group of tanks. An example would be to use information on specific heat for each tank in the group. The decay heat is due in large part to ${ }^{137} \mathrm{Cs}$ and to a lesser degree to ${ }^{90} \mathrm{Sr}$. The ${ }^{137} \mathrm{Cs}$ and ${ }^{90} \mathrm{Sr}$ are also major components of the inhalation and direct radiation doses. If a correlation between the specific heat and the sample results for ${ }^{137} \mathrm{Cs}$ and ${ }^{90} \mathrm{Sr}$ can be developed, then it may be possible to develop or use a ULD for a tank or group of tanks.

- Some accident scenarios are dominated by one type of dose. The reanalysis of the waste leak accidents shows that shine from the surface pool of waste is the major dose contributor for the onsite worker. Use of ${ }^{137} \mathrm{Cs}$ data developed from a correlation such as that described above could be useful in developing a ULD.

- Sample data for supernatant, especially in DSTs, is in many cases representative of the bulk supernatant in the tank from which it is taken. If sample data for all three radionuclides are available for the supernatant, a ULD calculated using that data is probably representative for the tank from which the samples are taken. This is a generalization and requires that the safety analyst examine the tanks and accident scenario to determine whether this generalization is appropriate. This generalization does not apply to interstitial liquids or small puddles of liquid on a waste surface.

- Tank histories also may be useful. Many tanks do not contain much waste or have not received new waste in many years. If specific tanks or groups of tanks are being evaluated, tank histories should be examined. 
RPP-5924 REV 0

\subsection{ATMOSPHERIC DISPERSION COEFFICIENTS}

\subsection{DISCUSSION OF TERMS AND RESULTS}

This section contains the atmospheric dispersion coefficients generated for the FSAR accident scenarios (HNF-SD-WM-SAR-067). Section 5.1.1 defines the atmospheric dispersion factor and discusses its use. Sections 5.1.2 through 5.1.6 discuss the specific values generated for atmospheric dispersion coefficients in this report, and Section 5.2 summarizes the selection of appropriate values for the scenarios of interest. Once the appropriate atmospheric dispersion coefficients are selected, they can be used with the equations provided in Section 6.2 and with the inventories generated in Section 3.0 to evaluate accident consequences.

\subsubsection{Atmospheric Dispersion Coefficient}

The atmospheric dispersion coefficient is the normalized air concentration at the receptor. It represents the dilution of an airborne contaminant by atmospheric mixing and turbulence. It is the ratio of the average contaminant air concentration at the receptor to the contaminant release rate at the release point. It is used to determine the dose consequences for a receptor based on the quantity released (i.e., the source term), atmospheric conditions, and the distance to the receptor of interest.

In this report, the onsite receptors are assumed to be located $100 \mathrm{~m}$ from the release point. The offsite receptor is assumed to be located at the Site boundary. The Site boundary values for the atmospheric dispersion coefficient are based on the minimum distance from the nearest tank farm (or associated waste transfer lines) to the Hanford Site boundary. Appendix A3.3 of DOE-STD-3009-94 states: "The determination of site boundary distances should be made in accordance with the procedure outlined in Position 1.2 of U.S. Nuclear Regulatory Commission (NRC) Regulatory Guide 1.145." Position 1.2 indicates that the site is to be divided into 16 sectors, each with an angle of $22.5^{\circ}$, to determine meteorological conditions, but a $45^{\circ}$ sector should be considered in computing the minimum distance to the site boundary. The $45^{\circ}$ sector is centered on the $22.5^{\circ}$ sector. The larger sector is used to account for any non-linearities in the wind patterns that might cause the wind in one sector to reach the Site boundary in the adjoining sector. A $45^{\circ}$ sector was used to evaluate the offsite receptor distances. Since the atmospheric dispersion coefficient for the onsite receptor is evaluated assuming a 100 -m distance from the source in all sectors, the sector width does not affect the onsite receptor calculation. The near bank of the Columbia River was used as the Site boundary to the north and the east.

All values for atmospheric dispersion coefficients in this report were generated using the GXQ computer program, which is documented in WHC-SD-GN-SWD-30002, GXQ User's Guide. The GXQ output files for all cases are included in Appendix A. The output files identify the name of the joint frequency data files used by GXQ. The joint frequency data used are 9-year averaged data (1983 to 1991) from the Hanford Site 
meteorology tower in the 200 Area. All GXQ atmospheric dispersion coefficients are generated using the methods described in NRC Regulatory Guide 1.145, Atmospheric Dispersion Models for Potential Accident Consequence Assessments at Nuclear Power Plants. The NRC Regulatory Guide 1.145 indicates that the larger of the 99.5 percent sector and 95 percent overall should be used. Appendix A of DOE-STD-3009-94 indicates the 95 percent overall factor should be used. The 95 percent overall value for the atmospheric dispersion coefficient is used for this safety analysis to be consistent with Appendix A of DOE-STD-3009-94.

Corrections may be appropriate for several mechanisms depending on the details of the accident scenario. These mechanisms are plume meander, plume depletion, momentum/buoyancy rise, and area source effects. Plume meander is discussed in Section 5.1.4. The best way to include the other mechanisms is to calculate scenariospecific atmospheric dispersion coefficients that employ the appropriate models. The magnitude of the potential effects using these models is discussed in Section 5.1.6.

The GXQ program has been verified and benchmarked against the GENII computer code (PNL-6584). The program is also verified to produce atmospheric dispersion coefficients consistent with NRC Regulatory Guide 1.145 methodology. For more detailed information on the models used in GXQ and their applicability, the reader should refer to the GXQ documentation in WHC-SD-GN-SWD-30002 and its references.

\subsubsection{Bounding Atmospheric Dispersion Coefficients}

Since atmospheric conditions fluctuate, a bounding atmospheric condition is determined to be that condition that causes a downwind concentration of airborne contaminants that is exceeded only a small fraction of time due to weather fluctuations. NRC Regulatory Guide 1.145 defines this fraction of exceedance as 0.5 percent for each sector or 5 percent for the overall site. The Hanford Site is broken up into 16 sectors, which represent 16 compass directions (i.e., S, SSW, SW, ..., ESE, SE, SSE). Atmospheric dispersion coefficients are generated for weather conditions that result in downwind concentrations that are exceeded only 0.5 percent of the time in the maximum sector or 5 percent of the time for the overall site. These atmospheric dispersion coefficients are also referred to as the 99.5 percent maximum sector and the 95 percent overall site atmospheric dispersion coefficient values, respectively. The 95 percent overall value is used to assess the dose consequences in the accident scenarios as specified in Appendix A of DOE-STD-3009-94. The distances to the Site boundary are determined based on a $45^{\circ}$ sector, as discussed in Section 5.1.1. The distances to the Site boundary are given in Table 5-1.

These atmospheric dispersion coefficients represent minimum dispersing conditions that result in maximum downwind concentrations (i.e., concentrations exceeded only a very small fraction of the time). These values will therefore result in very conservative estimates of accident consequences. Tables 5-2 and 5-3 contain the bounding atmospheric dispersion coefficients (X/Q' and $\mathrm{X} / \mathrm{Q}$ ) (95 percent overall) for the onsite and offsite receptors. 
Table 5-1. Site Boundary Distances.

\begin{tabular}{|l|c|}
\hline \multicolumn{1}{|c|}{ Sector } & $\begin{array}{c}\text { Minimum Distance to the } \\
\text { Site Boundary } \\
\text { with a 45 }{ }^{\circ} \text { Sector (m) }\end{array}$ \\
\hline S & 15,360 \\
\hline SSW & 15,360 \\
\hline SW & 13,200 \\
\hline WSW & 11,100 \\
\hline W & 11,100 \\
\hline WNW & 11,100 \\
\hline NW & 10,800 \\
\hline NNW & 8,690 \\
\hline N & 8,690 \\
\hline NNE & 8,970 \\
\hline NE & 10,430 \\
\hline ENE & 10,530 \\
\hline E & 11,160 \\
\hline ESE & 15,190 \\
\hline SE & 21,050 \\
\hline SSE & 15,360 \\
\hline & \\
\hline
\end{tabular}

Table 5-2. Acute Centerline Dispersion Cocfficients for 200 Area Tank Farm to Onsite Receptor at One Hundred Meters.

\begin{tabular}{|c|c|c|c|}
\hline $\begin{array}{c}\text { Meteorological } \\
\text { Condition }\end{array}$ & $\begin{array}{l}X / Q^{\prime} \\
\left(s / m^{3}\right)\end{array}$ & $\begin{array}{c}\mathrm{X} / \mathrm{Q}^{\prime} \text { with } \\
\text { Plume Meander } \\
\left(\mathrm{s} / \mathrm{m}^{3}\right)\end{array}$ & $\begin{array}{c}\text { Maximum Puff } \\
\qquad / \mathrm{Q} \\
\left(1 / \mathrm{m}^{3}\right)\end{array}$ \\
\hline 95 percent overall & $3.28 \mathrm{E}-02$ & $9.40 \mathrm{E}-03$ & $8.88 \mathrm{E}-03$ \\
\hline $\begin{array}{l}\text { Chronic annual } \\
\text { average }\end{array}$ & $4.03 \mathrm{E}-04$ & NA & $\mathrm{NA}$ \\
\hline 50th percentile & $5.33 \mathrm{E}-03$ & $2.27 \mathrm{E}-03$ & $9.48 \mathrm{E}-04$ \\
\hline
\end{tabular}


Table 5-3. Acute Centerline Dispersion Coefficients for 200 Area Tank Farm Release to Offsite Receptor in 45-Degree Sectors.

\begin{tabular}{|c|c|c|c|}
\hline $\begin{array}{l}\text { Meteorological } \\
\text { Condition }\end{array}$ & $\begin{array}{l}X / Q^{\prime} \\
\left(\mathrm{s} / \mathrm{m}^{3}\right)\end{array}$ & $\begin{array}{c}\text { X/Q' with } \\
\text { Plume Meander } \\
\left(\mathrm{s} / \mathrm{m}^{3}\right)\end{array}$ & $\begin{array}{l}\text { Maximum Puff } \\
\text { X/Q }\left(1 / \mathbf{m}^{3}\right)\end{array}$ \\
\hline 95 percent overall & $2.22 \mathrm{E}-05$ & $1.74 \mathrm{E}-05$ & $5.06 \mathrm{E}-08$ \\
\hline $\begin{array}{l}\text { Chronic annual } \\
\text { average }\end{array}$ & $1.47 \mathrm{E}-07$ & NA & $\mathrm{NA}$ \\
\hline 50th percentile & $4.48 \mathrm{E}-06$ & $3.83 \mathrm{E}-06$ & $1.04 \mathrm{E}-08$ \\
\hline
\end{tabular}

\subsubsection{Chronic Annual Average Meteorology}

Chronic annual average X/Q' values are provided for routine, long-term release scenarios. Chronic annual average $X / Q^{\prime}$ values are calculated for each sector, and the sector with the highest chronic annual average X/Q' value is reported. It is a "sector-averaged" value, which assumes there is no horizontal cross wind variation in concentration within the sector. Chronic annual average $\mathrm{X} / \mathrm{Q}$ ' values are appropriate for long-term or routine releases not normally associated with accident conditions. The values are included in this report to allow credit for a reduction in the $\mathrm{X} / \mathrm{Q}^{\prime}$ value for long-duration releases in accordance with NRC Regulatory Guide 1.145.

NRC Regulatory Guide 1.145 recommends the use of a logarithmic interpolation procedure to determine the $\mathrm{X} / \mathrm{Q}$ ' for long-duration releases. The logarithmic interpolation procedure requires chronic annual average X/Q' values, as described in the following section on plume meander. Tables 5-2 and 5-3 also contain chronic annual average $X / Q^{\prime}$ values for ground-level releases.

\subsubsection{Plume Meander}

Plume meander is accounted for in GXQ using the empirical model given in NRC Regulatory Guide 1.145. Credit for plume meander may be taken if the duration of the release is 1 hour or greater. Column 3 of 'Tables 5-2 and 5-3 contains X/Q' values wilh plume meander for acute (non-routine) ground release scenarios.

The X/Q' values with plume meander may be used for release durations from I to 2 hours. For release durations greater than 2 hours, NRC Regulatory Guide 1.145 recommends that a logarithmic interpolation be used between the acute hounding $X / Q^{\prime}$ value with plume meander and the chronic annual average $X / Q^{\prime}$ value. For purposes of interpolation, the acute bounding value with plume meander represents a 2 -hour value, and the chronic annual average value represents an 8,760-hour (1-year) value. Section 5.2.3 provides an example of the logarithmic interpolation procedure. 


\subsubsection{Puff Release Atmospheric Dispersion Coefficient for Toxicological Releases}

The peak concentration is of concern for releases of chemicals. For a continuous release, the integrated $\mathrm{X} / \mathrm{Q}^{\prime}\left(\mathrm{s} / \mathrm{m}^{3}\right)$ is used. There can be significant windward diffusion for release durations that have a plume travel time that is long in comparison to the release duration. Hence, the use of the integrated plume $X / Q^{\prime}$ values for deriving peak air concentration can be overly conservative. For instantaneous or short duration releases, the maximum puff $\mathrm{X} / \mathrm{Q}\left(1 / \mathrm{m}^{3}\right)$ can be used. (A release is essentially instantaneous when its release duration is much less than the plume traveling time to the maximum onsite or offsite individual). Most toxicological consequence analyses in the RPP FSAR assume a 60 -second release for a short duration release rather than a puff release (HNF-SD-WM-SAR-067). Modeling a release of less than 60 seconds as a 60 -second continuous release is allowed since a puff release produces a conservative instantaneous concentration while the chemical effects are not instantaneous. Modeling a release of less than 60 seconds as a 60 -second continuous release produces lower concentrations onsite than modeling it as a puff release, but the continuous release may produce higher offsite concentrations. Since the puff release is used in some scenarios in the FSAR, both the puff and continuous release data are furnished here for the analyst to use. Tables 5-2 and 5-3 contain maximum puff $\mathrm{X} / \mathrm{Q}$ values for ground level releases for onsite and offsite receptors, respectively.

\subsubsection{Other Models}

In addition to plume meander, other effects such as plume depletion, buoyancy effects, and source size effects can be included in the atmospheric dispersion models. Values for the atmospheric dispersion coefficients for these effects are not given because they need to be calculated for scenario-specific parameters. The GXQ manual and its references need to be consulted for application of the models. Estimates of the magnitudes of the effects are given but these estimates should not be applied to FSAR analysis without considering all scenario details. The models are briefly discussed below.

5.1.6.1 Plume Depletion. The plume concentrations will decrease as the plume moves downwind and material falls out of the plume. The amount of fallout will depend on the particle size distribution in the plume. Plume depletion in GXQ is calculated using the Chamberlain model described in Meteorology and Atomic Energy (Slade 1968). An important parameter in evaluating the magnitude of the effect is the deposition velocity, which must be input to use the model. Deposition from a spray leak accident is considered in HNF-SD-WM-CN-096, Refined Radiological and Toxicological Consequences of Bounding Spray Accidents in Tank Farm Waste Transfer Pits. HNF-SD-WM-CN-096 used the data from the contamination resulting from an actual accidental pressurization of a line with an open nozzle and showed that the data supported a deposition velocity of $0.15 \mathrm{~cm} / \mathrm{s}$. The effects of plume depletion on X/Q' with a $0.15 \mathrm{~cm} / \mathrm{s}$ deposition velocity are shown in Table 5-4 for an acute release. The doses are directly proportional to the $\mathrm{X} / \mathrm{Q}^{\prime}$ so the fractional reduction in the $\mathrm{X} / \mathrm{Q}^{\prime}$ corresponds to the same fractional reduction in the dose. 
Table 5-4. Effects of Plume Depletion.

\begin{tabular}{|l|c|c|c|}
\hline \multicolumn{1}{|c|}{ Receptor } & $\begin{array}{c}\text { Acute } \\
\mathbf{X} / \mathbf{Q}^{\prime} \text { with } \\
\text { Deposition }\left(\mathbf{s}_{\mathbf{~}} \mathbf{m}^{\mathbf{3}}\right)\end{array}$ & $\begin{array}{c}\text { Acute } \\
\mathbf{X} / \mathbf{Q}^{\prime} \text { without } \\
\text { Deposition }\left(\mathbf{s} / \mathbf{m}^{\mathbf{3}}\right)\end{array}$ & $\begin{array}{c}\mathrm{X} / \mathbf{Q}^{\prime} \text { with Deposition } \\
\text { Divided by X/Q } \\
\text { without Deposition }\end{array}$ \\
\hline Onsite & $2.84 \mathrm{E}-02$ & $3.28 \mathrm{E}-02$ & 0.866 \\
\hline Offsite & $1.14 \mathrm{E}-05$ & $2.22 \mathrm{E}-05$ & 0.514 \\
\hline
\end{tabular}

The reduction is larger offsite since there is more time for transport to the offsite receptor and hence more depletion. The magnitude of the effect depends on release duration and therefore the plume depletion needs to be calculated for the specific accident scenarios. Also, if plume depletion is considered, resuspension may become a factor, although resuspension is usually argued to be negligible unless the receptor is assumed to remain downwind of the contaminated area for very long periods (i.c., years).

5.1.6.2 Momentum and Buoyancy Effects. Additional plume rise may occur if the plume is released from the source with an initial momentum or if the initial temperature of the plume is higher than the temperature of the surrounding air. This plume rise can result in additional dispersion and reduced concentrations at the receptor. GXQ uses the Briggs models (see WHC-SD-GN-SWD-30002) to calculate momentum and buoyancy effects. The models may be used in GXQ in two ways, with one being based on the models used in the MACCS computer code, and the second based on the ISC-2 computer code (see WHC-SD-GN-SWD-30002).

The problem with implementing these models for tank farms accident scenarios is that burn rates, temperature, and flows are not well known. For instance, combustion products from a fire in a tank may be released through one or several risers at different burn rates resulting in a wide range of flows and temperatures. The models, however, are available for specific scenarios if parameters are known well enough to implement these models.

5.1.6.3 Source Size. The Gaussian plume model used in the GXQ computer program assumes a point source (WHC-SD-GN-SWD-30002). For some accident scenarios such as pool leaks, the source may have significant dimensions compared to the distance to the receptor. The finite source size will result in some additional dispersion at the source and reduced concentrations at the receptor. The 95 percent overall $X / Q^{\prime}$ is shown in Table 5-5 for different source diameters. The analysis assumes the receptor remains a constant distance from the center of the source. The onsite $X / Q^{\prime}$ is about 40 percent of the uncorrected $X / Q^{\prime}$ for a 30-m-diameter source. The effect offsite is not significant since a 30-m source still is effectively a point source for a receptor $7 \mathrm{~km}$ or more away. The doses are directly proportional to the $X / Q^{\prime}$ so the fraction reduction in $X / Q^{\prime}$ corresponds to the same fraction reduction in dose. 
Table 5-5. Effects of Source Width on Receptor Dose.

\begin{tabular}{|c|c|c|c|c|}
\hline $\begin{array}{l}\text { Source Width } \\
\text { (m) }\end{array}$ & $\begin{array}{c}\text { Acute } \\
\text { X/Q' Onsite } \\
\left(\mathbf{s} / \mathbf{m}^{3}\right) \\
\end{array}$ & $\begin{array}{c}\mathrm{X} / \mathrm{Q}^{\prime} \text { Onsite } \\
\text { over Zero } \\
\text { Width X/Q' }\end{array}$ & $\begin{array}{c}\text { Acute } \\
\text { X/Q' Offsite } \\
\left(\mathbf{s} / \mathbf{m}^{3}\right) \\
\end{array}$ & $\begin{array}{c}X / Q^{\prime} \text { Offsite } \\
\text { over Zero } \\
\text { Width } X / Q^{\prime}\end{array}$ \\
\hline 0 & $3.28 \mathrm{E}-02$ & 1.0 & $2.22 \mathrm{E}-05$ & 1.0 \\
\hline 10 & $2.24 \mathrm{E}-02$ & 0.683 & $2.21 \mathrm{E}-05$ & 0.995 \\
\hline 30 & $1.31 \mathrm{E}-02$ & 0.399 & $2.19 \mathrm{E}-05$ & 0.986 \\
\hline
\end{tabular}

This correction needs to be applied with carc. For instance, the internal accident phenomena in a waste tank may spread released material over the entire 75 - $\mathrm{ft}$ diameter of the tank, but if the actual release from the tank to the environment is predominantly through a single riser, the release from the tank should be treated as a point source.

If the radioactive aerosol concentration in the tank headspace is known, the concentration could be used to back calculate a virtual source that would produce that concentration when the plume dimensions approximate the headspace dimensions. The release mechanisms will need to be considered carcfully to show that the model is appropriate and conservative. The concentration must be released uniformly to the environment and the concentration in the headspace must be known. This effect could be modeled using GXQ for specific scenarios.

\subsection{SELECTION OF APPROPRIATE ATMOSPHERIC DISPERSION COEFFICENTS}

This section discusses the selection of appropriate atmospheric dispersion coefficients from Tables 5-2 and 5-3 for radioactive and toxic chemical releases based on the scenario of interest. The guidelines outline the specific atmospheric dispersion coefficient to be used for most accident scenarios. As discussed in Section 5.1.6, scenario-specific calculations can be made invoking plume depletion, plume rise, or virtual source models where appropriatc.

\subsubsection{Release Duration Less than One Hour}

For accident scenarios with release durations less than 1 hour, the bounding ( 95 percent) integrated X/Q' values (Column 2 of Tables 5-2 and 5-3) should be used to calculate radiological dose consequences. The corresponding 50 percent integrated $X / Q^{\prime}$ values in Tables 5-2 and 5-3 may be used for beyond design basis events. Comparison of 50 percent and 95 percent values can also give an estimate for the degree of conservatism in the analysis. Tables 5-2 and 5-3 apply to releases for the maximum onsite and offsite receptors, respectively. 


\section{RPP-5924 REV 0}

\subsubsection{Release Duration from One to Two Hours}

For accident scenarios with a release duration from 1 to 2 hours, the bounding (95 percent) integrated X/Q' values with plume meander (Column 3 of Tables 5-2 and 5-3) should be used to calculate radiological dose consequences.

\subsubsection{Release Duration Greater than Two Hours}

For accident scenarios with release durations from 2 hours to 8,760 hours (1 year), NRC Regulatory Guide 1.145 recommends that a logarithmic interpolation be used between the $\mathrm{X} / \mathrm{Q}^{\prime}$ value with plume meander (Row 1, Column 3 of Tables 5-2 and 5-3) for ground and the chronic annual average $X / Q^{\prime}$ value (Row 2, Column 2 of 'Tables 5-2 and 5-3).

For example, to determine the logarithmic interpolation for an onsite receptor with a ground level release, use the plume meander adjusted X/Q' of $9.40 \times 10^{-3} \mathrm{~s} / \mathrm{m}^{3}$

(Column 3, Row 1 of Table 5-2), and the chronic annual average X/Q' of $4.03 \times 10^{-4} \mathrm{~s} / \mathrm{m}^{3}$ (Column 2, Row 2 of Table 5-2). If there is an 8-hour ground level release, the X/Q' ( 8 hours) is calculated as follows:

$$
\frac{\log \left(9.40 \times 10^{-3}\right)-\log \left(\mathrm{X} / \mathrm{Q}^{\prime} 8 \text { hour }\right)}{\log \left(9.40 \times 10^{-3}\right)-\log \left(4.03 \times 10^{-4}\right)}=\frac{\log (2 \text { hour })-\log (8 \text { hour })}{\log (2 \text { hour })-\log (8,760 \text { hour })}
$$

From this equation, the X/Q' (8 hours) is $5.58 \times 10^{-3} \mathrm{~s} / \mathrm{m}^{3}$.

\subsubsection{Puff Releases}

A puff release model can be used for toxic releases. A continuous release model should be used onsite with a minimum release time of 60 seconds as this model will produce lower results while still being conservative. The puff release model will produce lower results offsite for release durations of less than 439 seconds. 


\subsection{RADIOLOGICAL DOSE CALCULATIONS}

\subsection{RADIOLOGICAL EXPOSURE PATHWAYS}

Two potential radiological exposure pathways are associated with accidental releases of radioactive materials: the internal and external exposure pathways. The total radioactive dose received by an individual is equal to the sum of the dose contributions from the internal and external exposure pathways.

The major internal exposure pathway for tank farm accidents is the inhalation pathway. Exposure through the inhalation pathway occurs when an accident results in a release of airborne radioactive materials that are transported downwind and inhaled, or when radioactive materials that have been deposited on the ground during plume passage become resuspended and subsequently inhaled. The dose contribution from the inhalation of resuspended materials is orders of magnitude less than that from the inhalation of airborne radioactive materials during plume passage, as evidenced in calculations performed using the GENII computer code (PNL-6584).

The other internal exposure pathway is the ingestion pathway. Exposure through the ingestion pathway occurs when radioactive materials that have been deposited offsite are ingested, either by eating crops grown in, or animals raised on, contaminated soil or through drinking contaminated water. Potential doses from the ingestion pathway are not included in the comparison to risk guidelines because there are $\mathrm{DOE}$, state, and federal programs in place to prevent ingestion of contaminated food in the event of an accident. The primary determinant of exposure from the ingestion pathway is the effectiveness of public health measures (i.e., interdiction) rather than the severity of the accident itself. The ingestion pathway, if it occurs, is a slow-to-develop pathway and is not considered an immediate threat to an exposed population in the same sense as airborne plume exposures. A method of including doses from ingestion of leafy vegetables and fruits during the first 24 hours following the accident was developed for the calculations in WHC-SD-WM-SARR-016. This method is described in Appendix B. As mentioned in Chapter 2.0 of this report, the ingestion doses are calculated using GENII (PNL-6584). The current version of GENII uses the DCFs from ICRP-26. The code is being revised to use the newer DCFs from ICRP-68, ICRP-71, and ICRP-72 but is not ready for use. Therefore an adjustment of 1.1 is applied to the offsite dose calculation to envelop the ingestion effects for the calculations in this report.

The external exposure pathways include submersion, ground shine, and direct exposure from a concentrated radioactive source, such as a pool of liquid formed when radioactive material is spilled onto the ground. Submersion refers to the external dose received by a person located in the airborne radioactive plume during plume passage. Ground shine refers to the external dose received by a person standing on ground contaminated by radioactive materials deposited during passage of the airborne radioactive plume.

The inhalation and submersion doses are a function of the quantity of radioactive contaminants present at the receptor. The inhalation dose is calculated using the fraction of the total airborne release that contains particle sizes that are respirable. This is generally considered to be particles 


\section{RPP-5924 REV 0}

that are $10 \mu \mathrm{m}$ or smaller. The submersion dose, however, is calculated using the total airborne release quantity (i.e., considering all particle sizes). Large particles will tend to fall out of the plume and only a small fraction will reach the receptor. The total airborne release quantity is usually calculated using airborne release fractions (ARFs) from sources such as DOE-HDBK-3010-94.

The ARF is the fraction of the total material at risk (MAR) that becomes airborne as a result of some kind of stress (e.g., thermal or explosive) applied to the material during a postulated accident scenario. The total airborne release quantity is equal to the MAR $\times$ ARF and includes all particle sizes. The respirable airborne release quantity is calculated by multiplying the total airborne release quantity $(\mathrm{MAR} \times \mathrm{ARF})$ times the respirable fraction $(\mathrm{RF})$ associated with the stress applied to the material during the accident scenario. The RF is the fraction of the airborne materials that can be transported through air and inhaled into the human respiratory system (commonly assumed to be particles $10 \mu \mathrm{m}$ or smaller). So, the quantity of respirable material released equals the MAR $\times \mathrm{ARF} \times \mathrm{RF}$.

For many accident scenarios, the RF is 1 , which means the total airborne release quantity is assumed to be equal to the respirable airborne release quantity. Once again, this depends on the type of stress applied to the MAR during the accident scenario. For the radionuclide mixes of interest in the tank waste $\left({ }^{90} \mathrm{Sr},{ }^{137} \mathrm{Cs}, \mathrm{Pu},{ }^{241} \mathrm{Am}\right.$ [i.e., there are no short-lived noble gases or iodines]), the submersion doses are 3 to 4 orders of magnitude lower than the inhalation doses. The RF would have to be approximately 0.001 to 0.0001 for the submersion doses to be significant compared to the inhalation doses for the radionuclide mixes of interest in the tank waste. Since the RFs for all of the accidents of concern are on the order of 0.1 to 1 , the submersion doses will always be at least 2 to 3 orders of magnitude less than the inhalation doses and can therefore be neglected.

As with the ingestion pathway, the primary determinant of exposure from the ground shine pathway is the effectiveness of public health measures (i.e., interdiction) rather than the severity of the accident itself. The ground shine pathway, if it occurs, is a slow-to-develop pathway and is not considered an immediate threat to an exposed population in the same sense as airborne plume exposures. Therefore, the ground shine pathway is not included in the calculation of the radiological dose for comparison against the risk evaluation guidelines.

The dose contribution from the direct exposure pathway is negligible compared to that from the inhalation pathway for all of the tank farms accident scenarios except the scenarios involving a waste transfer line break. Waste transfer line breaks result in a spill of radioactive material that forms a pool of liquid and results in a direct radiation dose from the surface of the pool. For scenarios involving formation of a pool of radioactive liquid, the direct dose contribution to the total onsite dose is significant and is therefore included in the calculation of the total onsite radiological dose used to compare against the risk evaluation guidelines.

In summary, the radiological dose calculations addressed in this report include only the inhalation pathway for all accident scenarios except those resulting in a pool of radioactive materials. For liquid pool scenarios, the direct dose from the surface of the pool is also included in the dose calculations. Section 6.2 discusses the inhalation radiological dose calculation methods. Corrections to remove RFs for ingestion and submersion contributions are not 


\section{RPP-5924 REV 0}

necessary because the submersion dose is negligible and only a small fraction of the larger-thanrespirable particles will reach the offsite receptor and contribute to the ingestion dose.

The radioactive source terms for tank farm accidents consist only of particulates in liquid and solid forms. Because of physical conditions in the tank farm waste (e.g., temperatures, pressures, volatility), compounds (e.g., nitrates, hydroxides, salts) formed by radionuclides in tank farm waste do not exist in the gaseous form.

\subsection{RADIOLOGICAL DOSE CALCULATION METHODS}

The ULD values provided in Chapter 4.0 can be used along with the appropriate atmospheric dispersion coefficients in Section 5.0 to determine the radiological dose to either a maximum individual or a population. This is done using the following equation.

$$
D=Q(L) \frac{\mathrm{X}}{Q^{\prime}}\left(s / m^{3}\right) R\left(m^{3} / s\right) U L D(S v / L)
$$

where

$$
\begin{aligned}
& \mathrm{D}=\text { committed effective dose equivalent to receptor } \\
& \mathrm{Q}=\text { liters of respirable tank waste released } \\
& \mathrm{X} / \mathrm{Q}^{\prime}=\text { integrated atmospheric dispersion coefficient (from Tables 5-2 and 5-3) } \\
& \mathrm{R}=\text { breathing rate }\left(3.33 \times 10^{-4} \mathrm{~m}^{3} / \mathrm{s}\right. \text { typical acute breathing rate [light activity] or } \\
& \\
& \mathrm{ULD}= \\
& \quad \text { committed effective dose equivalent per liter inhaled. }
\end{aligned}
$$

The typical acute breathing rate $\left(3.33 \times 10^{-4} \mathrm{~m}^{3} / \mathrm{s}\right)$ is used to calculate the onsite receptor dose for all release durations up to 24 hours. The chronic breathing rate $\left(2.57 \times 10^{-4} \mathrm{~m}^{3} / \mathrm{s}\right)$ is used for offsite receptor dose calculations for release durations greater than 24 hours.

Calculations for events such as an unfiltered release caused by a HEPA filter rupture may expose the receptors to an inhalation dose for up to 1 year. The occupancy factor is a correction for the fact that the onsite receptor is onsite for only about 40 hours per week. Exposures of more than 24 hours should be calculated in the following manner.

- The light activity breathing rate $\left(3.33 \times 10^{-4} \mathrm{~m}^{3} / \mathrm{s}\right)$ should be used to calculate the onsite inhalation dose, even for long-term exposures. The chronic breathing rate assumes that the receptor is sleeping for 8 hours a day, which is not the case when the onsite receptor is at work.

- For releases of greater than 24-hours duration, the amount of material used for the dose calculation is determined by multiplying the total amount of material released by the occupancy factor. The occupancy factor is calculated by dividing 


\section{RPP-5924 REV 0}

the hours spent at work in a year by the total number of hours per year. Assuming 2,000 hours worked per year, this ratio would be

$$
2,000 \div 8,760=0.228
$$

- Offsite exposure calculations should assume an occupancy factor of 1 but should use the chronic breathing rate $\left(2.57 \times 10^{-4} \mathrm{~m}^{3} / \mathrm{s}\right)$ for releases with a duration greater than or equal to 24 hours.

Emergency response procedures will prevent large quantities of contaminated food from being ingested. However, it is expected that a finite time will be required for these procedures to be implemented. A method for including the dose from ingestion of fruits and leafy vegetables, ground shine, and resuspension has been developed that uses ULDs for ingestion as well as inhalation. Ingestion, resuspension, and ground shine are included as follows.

$$
\begin{aligned}
\text { Dose }(\text { total }) & =\text { Dose }(\text { inhalation })+\text { Dose }(\text { ingestion }) \\
& =\mathrm{Q} \times \mathrm{X} / \mathrm{Q}^{\prime} \times[\{\mathrm{ULD}(\text { inhalation }) \times \mathrm{BR}\}+\mathrm{ULD}(\text { ingestion })] .
\end{aligned}
$$

Note that the ingestion ULD is used in the same way as the inhalation ULD in the dose calculation except that it is not multiplied by the breathing rate. The "ingestion ULD" includes ground shine and resuspension. Ingestion doses should be included only for the offsite receptor since food is not grown onsite and the resuspension and ground contributions are small. The ingestion ULD contribution was calculated to be 0.3 to 7 percent of the inhalation dose. The transuranics that dominate the inhalation dose ULDs contribute only small fractions to the ingestion doses. The tanks with relatively large inhalation doses will have relatively small ingestion dose fractions.

Rather than attempting to evaluate the ingestion doses on a case-by-case basis, the offsite doses will be increased by 10 percent (i.e., multiplied by 1.1). The development of the ULDs is described in Appendix B. The total of the inhalation plus ingestion dose is bounded by

$$
\mathrm{ULD}_{\text {total }}=1.1 \mathrm{ULD}_{\text {inhalation, offsite }}
$$

ULDs for offsite calculations are given in Table 4-2 and include the 1.1 correction factor for ingestion. 


\subsection{DOSE RATE CALCULATION FOR HIGH-EFFICIENCY PARTICULATE AIR FILTERS}

Accident scenarios in the RPP FSAR (HNF-SD-WM-SAR-067) include failure of HEPA filters from overpressurization or high temperature (HNF-SD-WM-SAR-067, Section 3.3.2.4.2). A portion of the waste on the filter is assumed to be released when the filter fails. The amount of material released is determined using a different model in this document than was used in WHC-SD-WM-SARR-016. The filter release is determined using the following steps.

1. A calculation of the contact gamma dose rate at a specific measuring point is made for a unit quantity of material (normally $1 \mathrm{Ci}$ ) of ${ }^{137} \mathrm{Cs}$ and its ${ }^{137 \mathrm{~m}} \mathrm{Ba}$ daughter using a computer code such as MICROSHIELD (1992). An activity of $1 \mathrm{Ci}$ of ${ }^{137} \mathrm{Cs}$ implies $0.946 \mathrm{Ci}$ of ${ }^{137 \mathrm{~m}} \mathrm{Ba}$ since these two isotopes exist in equilibrium.

2. The filter is changed before the contact dose rate reaches $200 \mathrm{mrem} / \mathrm{h}$. The maximum

${ }^{137} \mathrm{Cs}$ activity on the filter is determined by dividing $200 \mathrm{mrem} / \mathrm{h}$ by the dose rate determined in step 1 .

3. The volume (liters) of waste on the filter is determined by dividing the activity determined in step 2 by the activity per liter for ${ }^{137} \mathrm{Cs}$. The number of liters of waste on the filter is calculated using a 95 th percentile ${ }^{137} \mathrm{Cs}$ concentration in the waste. The ULDs used in the safety analysis inhalation dose calculations are based on a 95th percentile tank-by-tank calculation of ULDs. Since the ULDs are based on the 95th percentile of the tank-by-tank ULDs, there is not a one-to-one correspondence between the 95th percentile ULD and the 95th percentile ${ }^{137} \mathrm{Cs}$ concentration. However, this method is a good approximation and can be used to obtain an estimate of the amount of material on the filter.

4. Once the number of liters of material on the filter is estimated, the release to the atmosphere can be estimated using the RFs for the appropriate scenario.

The gamma dose rate at the measuring point will be from contributions of other isotopes such as

${ }^{60} \mathrm{Co}$ and ${ }^{154} \mathrm{Eu}$ as well as bremsstrahlung from beta-emitting isotopes. The contribution will be relatively small, and because the dose rate is used to back calculate the quantity of material, it is conservative to assume that all the gamma ray activity is ${ }^{137} \mathrm{Cs}$.

It should also be noted that this calculation assumes the filters are uniformly loaded. The dose rate is sensitive to the distribution of radionuclides on the filter. The assumption that the distribution is uniform introduces some uncertainties but is considered acceptable as a method designed to obtain an estimate of the activities on the filters.

The 95th percentile ${ }^{137} \mathrm{Cs}$ concentrations are shown in Table 7-1. 
Table 7-1. Ninety-Fifth and Ninety-Ninth Percentile Points from the Lognormal Distribution for Cesium-137.

\begin{tabular}{|l|c|c|c|}
\hline \multicolumn{1}{|c|}{ Type of Sample } & $\begin{array}{c}\text { Number of } \\
\text { Tanks }\end{array}$ & $\begin{array}{c}\text { 95th Percentile } \\
(\mathbf{B q} / \mathbf{L})\end{array}$ & $\begin{array}{c}\text { 99th Percentile } \\
(\mathbf{B q} / \mathbf{L})\end{array}$ \\
\hline Single-shell tank solid & 58 & $9.86 \mathrm{E}+10$ & $4.78 \mathrm{E}+11$ \\
\hline Single-shell tank liquid & 28 & $3.88 \mathrm{E}+11$ & $2.61 \mathrm{E}+12$ \\
\hline Double-shell tank solid & 15 & $3.85 \mathrm{E}+10$ & $6.42 \mathrm{E}+10$ \\
\hline Double-shell tank liquid & 27 & $6.66 \mathrm{E}+10$ & $2.06 \mathrm{E}+11$ \\
\hline
\end{tabular}

The percentile points in Table $7-1$ were computed based on ${ }^{137} \mathrm{Cs}$ sample data obtained from the TCD (PNNL 1999). All of the ${ }^{137}$ Cs sample data wals obtained from the TCD (PNNL 1999). All observations below the detection limits were deleted. The data were divided into four sets by type of tank (SST and DST) and type of waste (liquid and solid). The final number of tanks with data is noted in Table 7-1.

For each tank, the mean ${ }^{137} \mathrm{Cs}$ concentration $(\mu \mathrm{Ci} / \mathrm{g}$ or $\mu \mathrm{Ci} / \mathrm{L})$ was computed. These means are listed in Appendix A of HNF-4534 (see Appendix $\mathrm{C}$ of this document). The concentration units $\left(\mu \mathrm{Ci} / \mathrm{g}\right.$ or $\mu \mathrm{Ci} / \mathrm{L}$ ) were converted to $\mathrm{Bq} / \mathrm{L}$ using $3.70 \times 10^{4} \mathrm{~Bq} / \mu \mathrm{Ci}$ and $1.60 \times 10^{3} \mathrm{~g} / \mathrm{L}$.

The computer program S-PLUS (S-PLUS 2000) was used to fit a lognormal distribution to the tank means. The quantiles corresponding to the 95 th and 99 th pereentile points of the lognormal distribution are given in Table $7-1$. The quantiles are the ${ }^{137} \mathrm{C}$ s concentrations $(\mathrm{Bq} / \mathrm{L})$ such that 95 or 99 percent of the "population" is to the left of the reported values. The units for the quantiles are bequerels per liter. A more complete description of how the lognormal distribution was fit to the data is contained in HNF-4534 (see Appendix C of this document). 


\subsection{REFERENCES}

10 CFR 835, “Occupational Radiation Protection," Code of Federal Regulations, as amended.

Brevick, C. H., 2000, Updated Calculation Methods for Tank Farm Unit Liter Doses (Attachment to Letter CO-00-RPP-270, Deliverable for Contract 4976, Release 8, Updated Dose Methods (L-03) to W. L. Cowley, March 27), Fluor Federal Services, Richland, Washington.

DOE O 435.1, Radioactive Waste Management, U.S. Department of Energy, Washinton, D.C.

DOE Order 5480.23, Nuclear Safety Analysis Reports, U.S. Department of Energy, Washington, D.C.

DOE Order 6430.1A, General Design Criteria, U.S. Department of Energy, Washington, D.C.

DOE HDBK-3010-94, 1994, Airborne Release Fractions/Rates and Respirable Fractions for Nonreactor Nuclear Facilities, U.S. Department of Energy, Washington, D.C.

DOE-STD-3009-94, 1994, Preparation Guide for U.S. Department of Energy Nonreactor Nuclear Facility Safety Analysis Reports, U.S. Department of Energy, Washington, D.C.

EPA-520/1-88-020, 1988, Federal Guidance Report No. 11, Limiting Values of Radionuclide Intake and Air Concentration and Dose Conversion Factors for Inhalation, Submersion, and Ingestion, U.S. Environmental Protection Agency, Office of Radiological Programs, Washington, D.C.

HNF-4534, 2000, Sample Based Unit Liter Dose Estimates, Rev. 1, CH2M HILL Hanford Group, Inc., Richland, Washington.

HNF-4754, 1999, Tank Waste Isotope Contributions, Fluor Daniel Northwest, Richland, Washington.

HNF-SD-WM-CN-096, 1997, Refined Radiological and Toxicological Consequences of Bounding Spray Accidents in Tank Farm Waste Transfer Pits, Flour Daniel Northwest, Inc., Richland, Washington.

HNF-SD-WM-SAR-067, 2000, Tank Waste Remediation System Final Safety Analysis Report, Rev. 1D, Lockheed Martin Hanford Corporation, Richland, Washington.

ICRP-26, 1977, Recommendations of the International Commission on Radiological Protection, Annals of the International Commission on Radiological Protection, Volume 1, Number 3, Elsevier Science, Tarrytown, New York.

ICRP-30, 1979, Limits for Intakes of Radionuclides by Workers, Annals of the International Commission on Radiological Protection, Volume 2, Number 3/4, Elsevier Science, Tarrytown, New York. 
ICRP-61, 1991, Annual Limits on Intake of Radionuclides by Workers Based on the 1990 Recommendations, Annals of the International Commission on Radiological Protection, Volume 21, Number 4, Elsevier Science, Tarrytown, New York.

ICRP-68, 1994, Dose Coefficients for Intakes of Radionuclides by Workers-Replacement of ICRP Publication 61, Annals of the International Commission on Radiological Protection, Volume 24, Number 4, Elsevier Science, Tarrytown, New York.

ICRP-71, 1995, Age Dependent Doses to Members of the Public from Intake of Radionuclides Part 4 Inhalation Dose Coefficients, Annals of the International Commission on Radiological Protection, Volume 25, Number 3-4, Elsevier Science, Tarrytown, New York.

ICRP-72, 1996, Age Dependent Doses to Members of the Public from Intake of Radionuclides Part 5 Compilation of Ingestion and Inhalation Dose Coefficients, Annals of the International Commission on Radiological Protection, Volume 26, Number 1, Elsevier Science, Tarrytown, New York.

MICROSHIELD, 1992, MICROSHIELD, Version 4, Grove Engineering Incorporated, Rockville, Maryland.

ORNL-5621, 1980, ORIGEN2-A Revised and Updated Version of the Oak Ridge Isotope Generation and Depletion Code, Oak Ridge National Laboratory, Oak Ridge Tennessee.

PNL-6584, 1988, GENII - The Hanford Environmental Radiation Dosimetry Software System, Volume 1, Pacific Northwest Laboratory, Richland, Washington.

PNNL, 1999, Tank Characterization Database, Version 3.28, available at http://twins.pnl.gov:8001/twins.htm, Pacific Northwest National Laboratory, Richland, Washington.

Regulatory Guide 1.145, 1982, Atmospheric Dispersion Models for Potential Accident Consequence Assessments at Nuclear Power Plants, U.S. Nuclear Regulatory Commission, Washington, D.C.

Reynolds, D. A., 1999, Assessment of Radionuclide Data Since 1995 Against the Source Term, (Interoffice Memorandum 74B50-99-013 to G.W. Gault, February 9) Lockheed Martin Hanford Corporation, Richland, Washington.

RPP-5667, 2000, Stochastic Consequence Analysis for Waste Leaks ,Rev. 0, Fluor Federal Services, Richland, Washington.

Slade, D. H., 1968, Meteorology and Atomic Energy, U.S. Atomic Energy Commission, Office Information Services, Washington D.C.

S-PLUS, 2000, S-PLUS, Data Analysis Products Division, MathSoft, Seattle, Washington 
Tri-Party Agreement, 1990, Hanford Federal Facility Agreement and Consent Order, 2 volumes, as amended, Washington State Department of Ecology, U.S. Environmental Protection Agency, and U.S. Department of Energy, Olympia, Washington.

TWRS-RT-SER-003, 1999, Safety Evaluation Report for the Tank Waste Remediation System (TWRS) Final Safety Analysis Report (FSAR) [HNF-SD-WM-SAR-067, Rev. H, September 1998] and Technical Safety Requirements [HNF-SD-WM-TSR-006, Rev. F2, August 1997], Rev. 0, U.S. Department of Energy, Richland Operations Office, Richland, Washington.

WHC-SD-GN-SWD-30002, 1993, GXQ Program Users ' Guide, Rev. 1, Westinghouse Hanford Company, Richland, Washington.

WHC-SD-WM-ER-400, 1995, Tank Waste Source Term Inventory Validation, Rev. 0, Volumes I and II, Westinghouse Hanford Company, Richland, Washington.

WHC-SD-WM-RPT-164, 1995, Inventories for Low-Level Waste Tank Waste, Rev. 0, Westinghouse Hanford Company, Richland, Washington.

WHC-SD-WM-SARR-016, 1996, Tank Waste Compositions and Atmospheric Dispersion Coefficients for Use in Safety Analysis Consequence Assessments, Rev. 2, Fluor Daniel Northwest, Richland, Washington.

WHC-SD-WM-SARR-037, 1996, Development of Radiological Concentrations and Unit Liter Doses for TWRS FSAR Radiological Consequence Calculations, Rev. 0, Westinghouse Hanford Company, Richland, Washington. 
RPP-5924 REV 0

This page intentionally left blank. 
RPP-5924 REV 0

APPENDIX A

GXQ COMPUTER CALCULATIONS

A-1 
RPP-5924 REV 0

This page intentionally left blank. 


\section{RPP-5924 REV 0}

\section{APPENDIX A \\ GXQ COMPUTER CALCULATIONS}

Files

TWRS45R2.IN input file for $95 \%$ overall, assuming $45^{\circ}$ sectors

TWRS45R2.OUT Output file for $95 \%$ overall, assuming $45^{\circ}$ sectors

TWRS45R3.OUT Output file for $95 \%$ overall, assuming $45^{\circ}$ sectors with plume meander

TWRS45R4.OUT Output file for $95 \%$ overall, assuming $45^{\circ}$ sectors, puff release

TWRS45R5.OUT Output file for annual average, assuming $45^{\circ}$ sectors

TWRS45R6.OUT Output file for 50\% meteorology, assuming $45^{\circ}$ sectors

TWRS45R7.OUT Output file for $50 \%$ meteorology, assuming $45^{\circ}$ sectors, plume meander

TWRS45R8.OUT Output file for 50\% meteorology, assuming $45^{\circ}$ sectors, puff release

TWRS45R9.OUT Output file for $95 \%$ overall, assuming $45^{\circ}$ sectors, deposition, $0.15 \mathrm{~cm} / \mathrm{s}$

TWRS45R10.OUT Output file for $95 \%$ overall, assuming $45^{\circ}$ sectors, $10 \mathrm{~m}$ wide source

TWRS4511.OUT Output file for $95 \%$ overall, assuming $45^{\circ}$ sectors, $30 \mathrm{~m}$ wide source 


\section{RPP-5924 REV 0}

TWRS FSAR 95\% overall river bd no BW/No PM, 45 degree sectors

C GXQ Version 4.0 Input File

c mode

$$
1
$$

C

C MODE CHOICE:

$c$ mode $=1$ then $X / Q$ based on Hanford site specific meteorology

$c$ mode $=2$ then $X / Q$ based on atmospheric stability class and wind speed

$c$ mode $=3$ then $X / Q$ plot file is created

$\mathrm{c}$

c LOGICAL CHOICES:

C ifox inorm icdf ichk isite ipop

$t \quad f \quad f \quad f \quad t \quad f$

$c$ ifox $=t$ then joint frequency used to compute frequency to exceed $x / Q$

$c=f$ then joint frequency used to compute annual average $X / Q$

$c$ inorm $=t$ then joint frequency data is normalized (as in GENII)

c $\quad=f$ then joint frequency data is un-normalized

$c$ icdf $=t$ then cumulative distribution file created (CDF.OUT)

c $=\mathrm{E}$ then no cumulative distribution file created

$\mathrm{C}$ ichk $=t$ then $\mathrm{X} / \mathrm{Q}$ parameter print option turned on

$\mathrm{C}=\mathrm{f}$ then no parameter print

c isite $=t$ then $X / Q$ based on joint frequency data for all 16 sectors

$\mathrm{C} \quad=\mathrm{f}$ then $\mathrm{X} / \mathrm{Q}$ based on joint frequency data of individual sectors

$c$ ipop $=t$ then $X / Q$ is population weighted

c $=\mathrm{f}$ then no population weighting

$\mathrm{C}$

C $X / Q$ AND WIND SPEED ADUUSTMENT MODELS:

C ipuff idep isrc iwind$$
0
$$
0

C DIFFUSION COEFFICIENT ADJUSTMENT MODELS:

C iwake ipm iflow ientr

$0 \quad 0 \quad 000$

C EFFECTIVE RELEASE HEIGHT ADJUSTMENT MODELS:

c (irise igrnd) iwash igrav

$\begin{array}{llll}0 & 0 & 0 & 0\end{array}$

c ipuff $=1$ then $X / Q$ calculated using puff model

C $\quad=0$ then $X / Q$ calculated using default continuous plume model

$c$ idep $=1$ then plume depletion model turned on (Chamberlain model)

$c$ isrc $=1$ then $X / Q$ multiplied by scalar

c $\quad=2$ then $X / Q$ adjusted by wind speed function

$c$ iwind $=1$ then wind speed corrected for plume height

c iwake = 1 then NRC RG 1.145 building wake model turned on

c $=2$ then MACCS virtual distance building wake model turned on

$c$ ipm = 1 then NRC RG 1.145 plume meander model turned on

C $\quad=2$ then 5 th Power Law plume meander model turned on

$\mathrm{c} \quad=3$ then sector average model turned on

c iflow $=1$ then sigmas adjusted for volume flow rate

$c$ ientr $=1$ then method of Pasquill used to account for entrainment

c irise $=1$ then MACCS buoyant plume rise model turned on

$\mathrm{C} \quad=2$ then ISC2 momentum/buoyancy plume rise model turned on

$c$ igrnd $=1$ then Mills buoyant plume rise modification for ground effects

c iwash $=1$ then stack downwash model turned on

c igrav $=1$ then gravitational settling model turned on

c $\quad=0$ unless specified otherwise, 0 turns model off

C

C PARAMETER INPUT:

$\mathrm{C}$

reference

frequency 


\section{RPP-5924 REV 0}

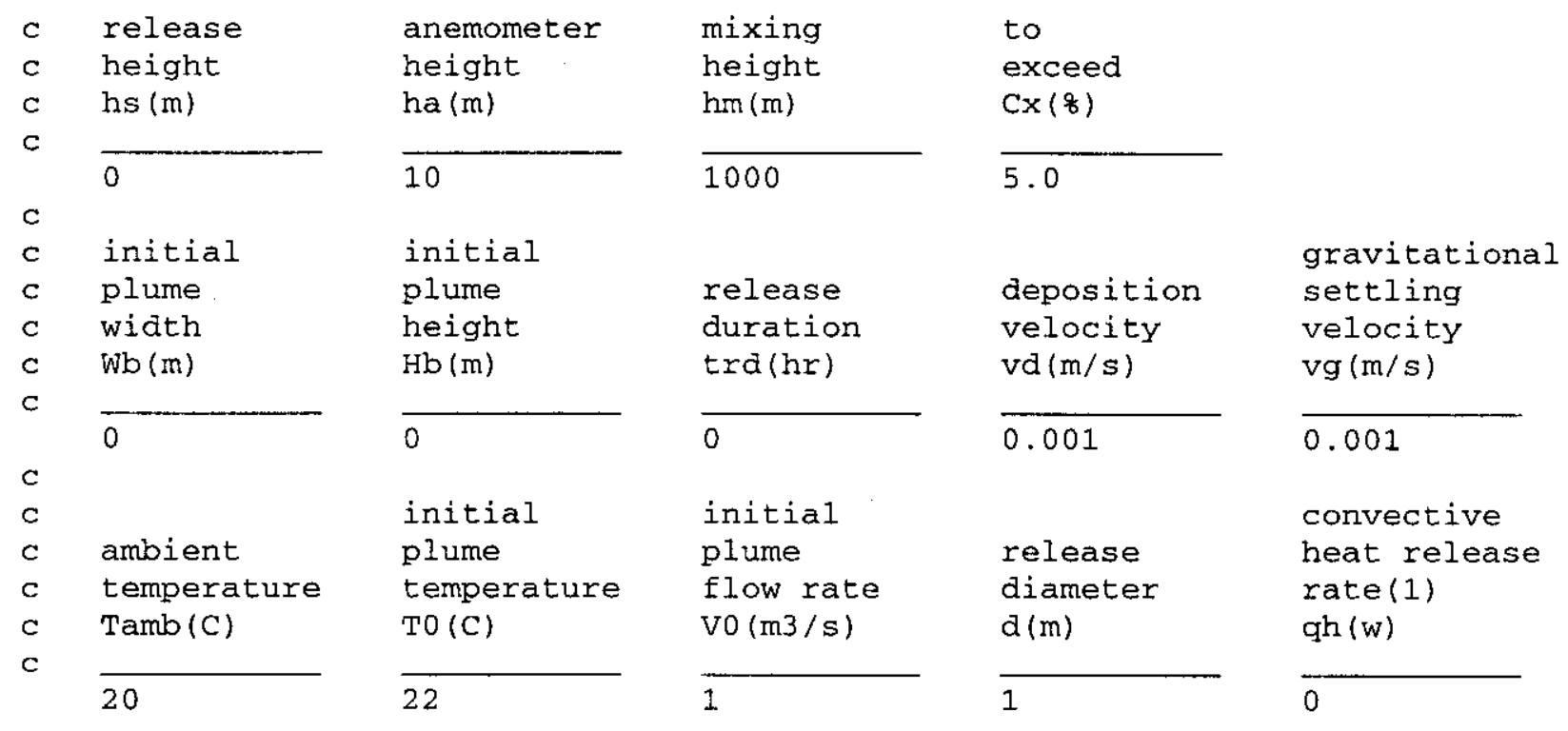

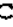

c (1) If zero then buoyant flux based on plume/ambient temperature difference.

$\mathrm{c}$

$\begin{array}{lll}\text { c } & \text { X/Q } & \text { Wind } \\ \text { C } & \text { scaling } & \text { Speed } \\ \text { C factor } & \text { Exponent } \\ \text { c } & c(?) & \text { a(?) } \\ \text { C } & \text { 1.00 } & -78\end{array}$

C

C RECEPTOR DEPENDENT DATA (no line limit)

C FOR MODE make RECEPTOR DEPENDENT DATA

c 1 (site specific) sector distance receptor-height

c 2 (by class \& wind speed) class windspeed distance offset receptor-height

c 3 (create plot file) class windspeed xmax imax ymax jmax xqmin power

C RECEPTOR PARAMETER DESCRIPTION

C sector $=0,1,2 \ldots($ all, S, SSW, etc.)

$\mathrm{C}$ distance $=$ receptor distance $(\mathrm{m})$

c receptor height $=$ height of receptor $(\mathrm{m})$

C class $=1,2,3,4,5,6,7$ (P-G stability class A, B, C, D, E, F, G)

C windspeed $=$ anemometer wind speed $(\mathrm{m} / \mathrm{s})$

$c$ offset $=$ offset from plume centerline (m)

c $x \max =$ maximum distance to plot or calculate to (m)

c imax $=$ distance intervals

c $y \max =\operatorname{maximum}$ offset to plot $(\mathrm{m})$

c jmax $=$ offset intervals

c $x$ qmin = minimum scaled $\mathrm{X} / \mathrm{Q}$ to calculate

c power $=$ exponent in power function step size

$0 \quad 100 \quad 0$

$115360 \quad 0$

$215360^{\circ} 0$

$313200 \quad 0$

$411100 \quad 0$

$511100 \quad 0$

$611100 \quad 0$

$\begin{array}{rrr}7 & 10800 & 0 \\ 8 & 8690 & 0\end{array}$ 
RPP-5924 REV 0

$\begin{array}{lrl}9 & 8690 & 0 \\ 10 & 8970 & 0 \\ 11 & 10430 & 0 \\ 12 & 10530 & 0 \\ 13 & 11160 & 0 \\ 14 & 15190 & 0 \\ 15 & 21050 & 0 \\ 16 & 15360 & 0\end{array}$

A-6 


\section{RPP-5924 REV 0}

Current Input File Name: twrs $45 \mathrm{r} 2$.IN

GXQ Version 4.0

December 19, 1994

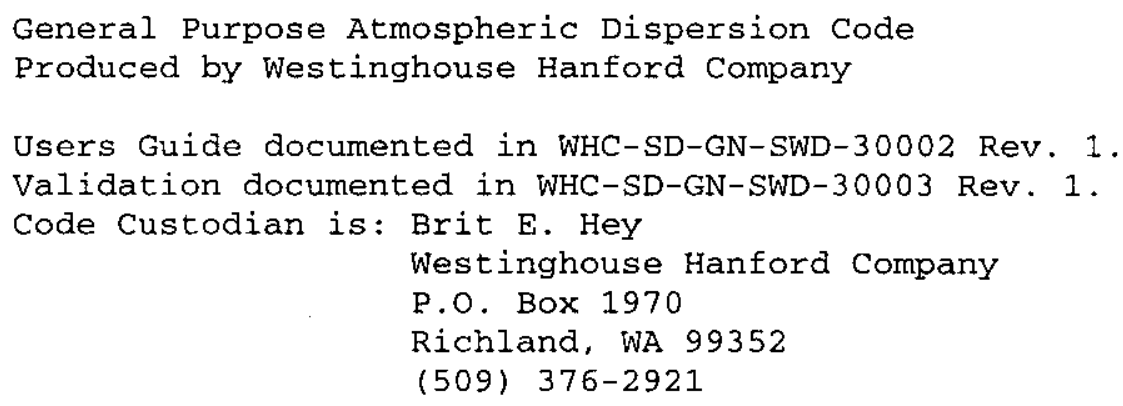




\section{RPP-5924 REV 0}

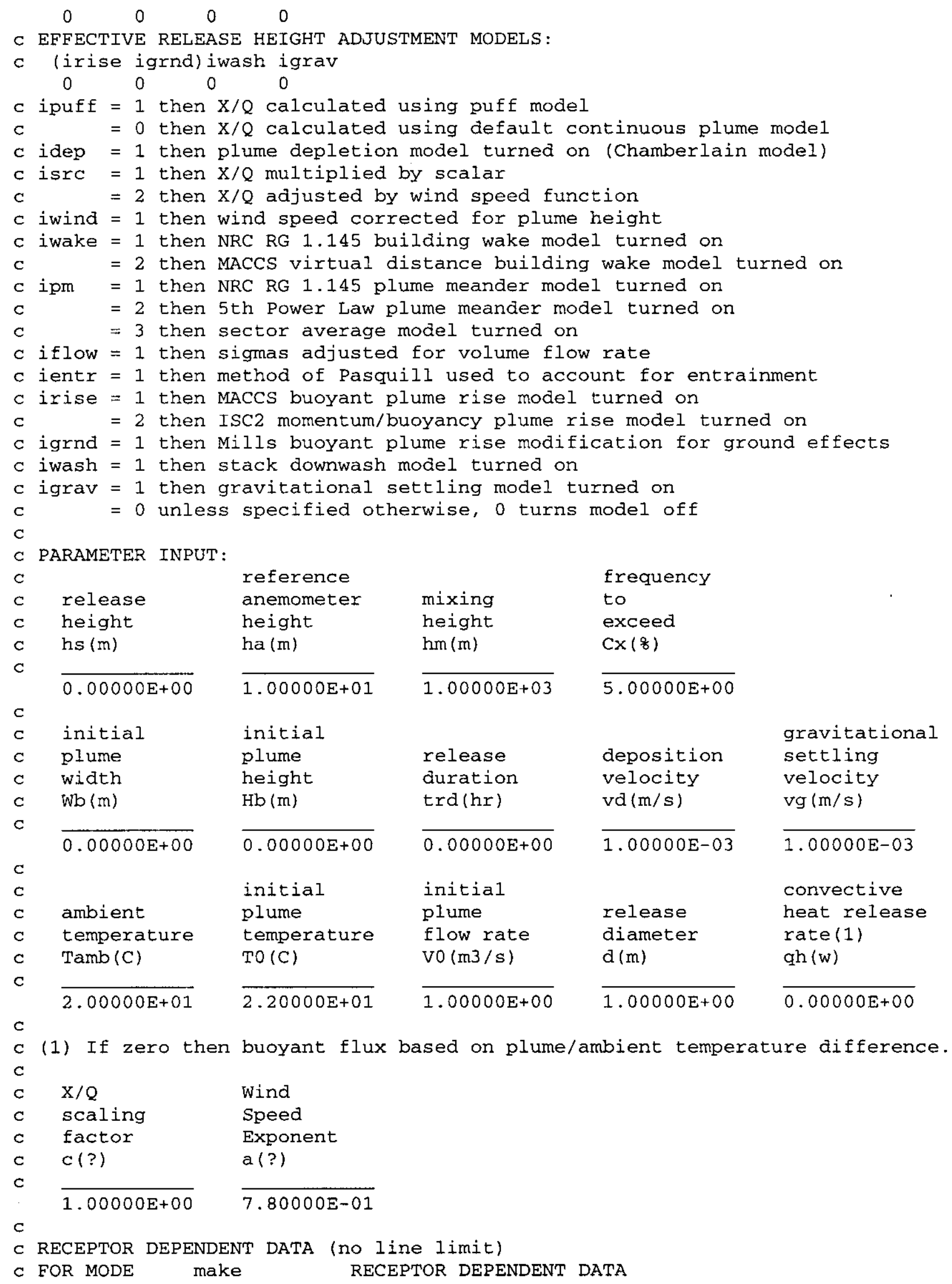




\section{RPP-5924 REV 0}

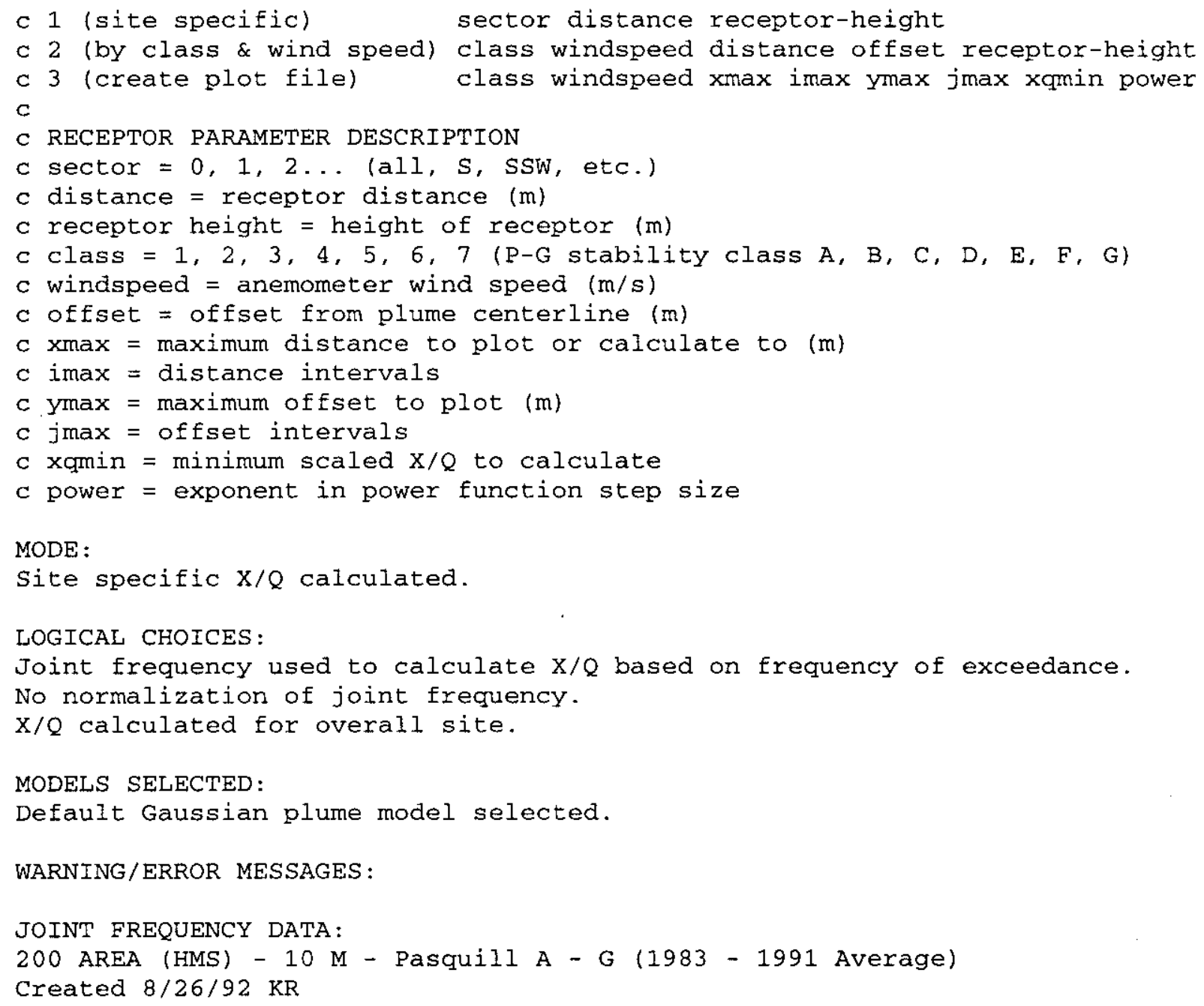

TWRS FSAR 958 overall river bd no BW/No PM, 45 degree sectors

\begin{tabular}{|c|c|c|c|c|c|c|c|c|}
\hline \multirow[b]{3}{*}{ SECTOR } & & & & & $\begin{array}{c}\text { TOTAL } \\
\text { POPULATION }\end{array}$ & $\begin{array}{l}\text { AVERAGE } \\
\text { INDIVIDUAL }\end{array}$ & & \\
\hline & & RECEPT & SECT. & & SCALED & SCALED & ATM. & WIND \\
\hline & $\begin{array}{l}\text { DISTANCE } \\
\text { (m) }\end{array}$ & $\begin{array}{l}\text { HEIGHT } \\
\text { (m) }\end{array}$ & $\begin{array}{c}\text { FREQ. } \\
(8)\end{array}$ & POPULATION & $\begin{array}{l}X / Q \\
(s / m 3)\end{array}$ & $\begin{array}{l}X / Q \\
(s / m 3)\end{array}$ & $\begin{array}{l}\text { STAB. } \\
\text { CLASS }\end{array}$ & $\begin{array}{l}\text { SPEED } \\
(\mathrm{m} / \mathrm{s})\end{array}$ \\
\hline ALL & 100 & 0 & 99.94 & 1 & $3.28 \mathrm{E}-02$ & $3.28 \mathrm{E}-02$ & F & 0.89 \\
\hline ALL & 15360 & 0 & 99.94 & 1 & $2.22 E-05$ & $2.22 E-05$ & $\mathrm{~F}$ & 0.89 \\
\hline
\end{tabular}




\section{RPP-5924 REV 0}

Current Input File Name: twrs $45 \times 3$. IN

GXQ Version 4.0

December 19,1994

General Purpose Atmospheric Dispersion Code

Produced by Westinghouse Hanford Company

Users Guide documented in WHC-SD-GN-SWD-30002 Rev. 1.

Validation documented in WHC-SD-GN-SWD-30003 Rev. 1.

Code Custodian is: Brit E. Hey

Westinghouse Hanford Company

P.O. Box 1970

Richland, WA 99352

(509) 376-2921

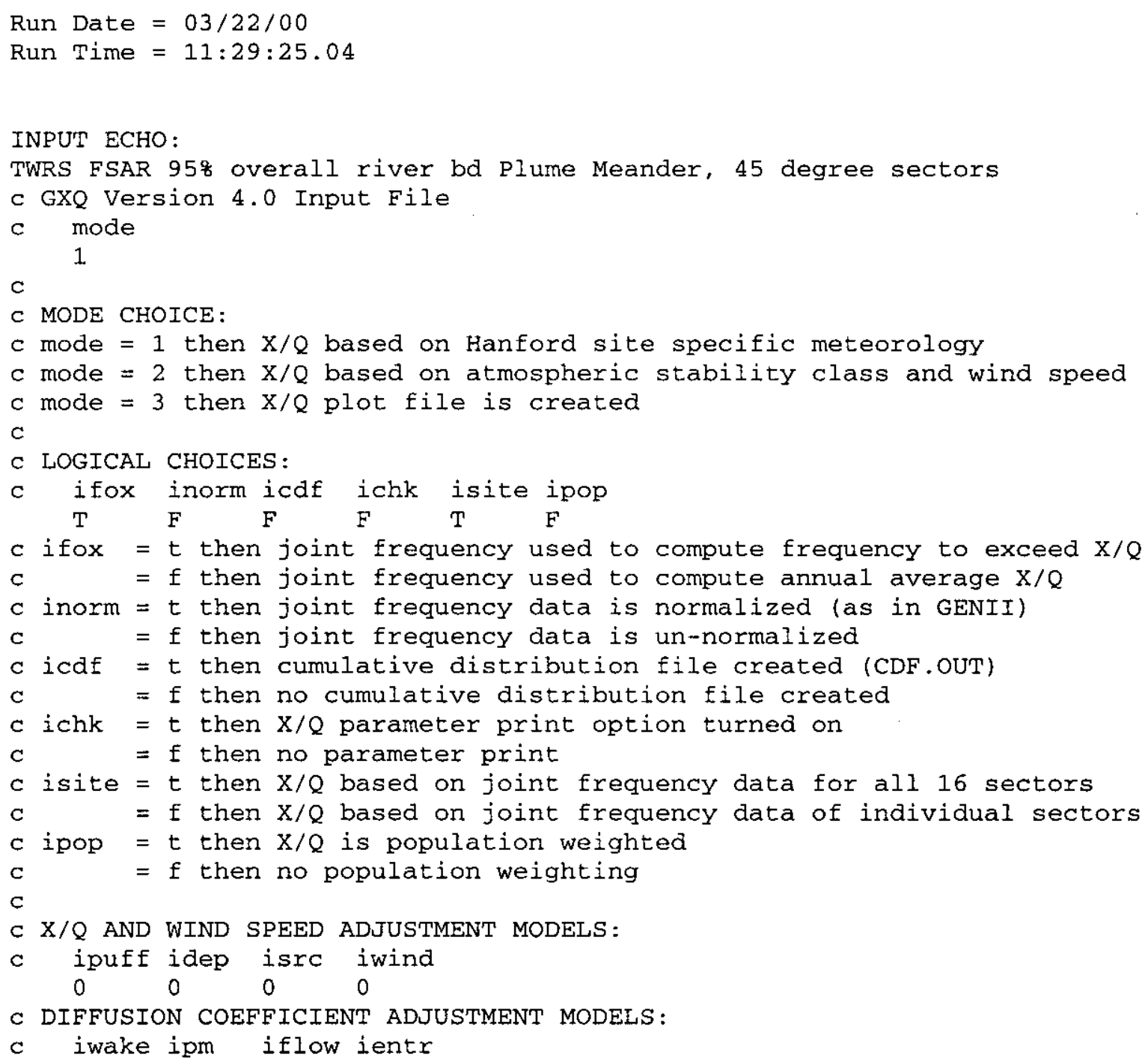




\section{RPP-5924 REV 0}

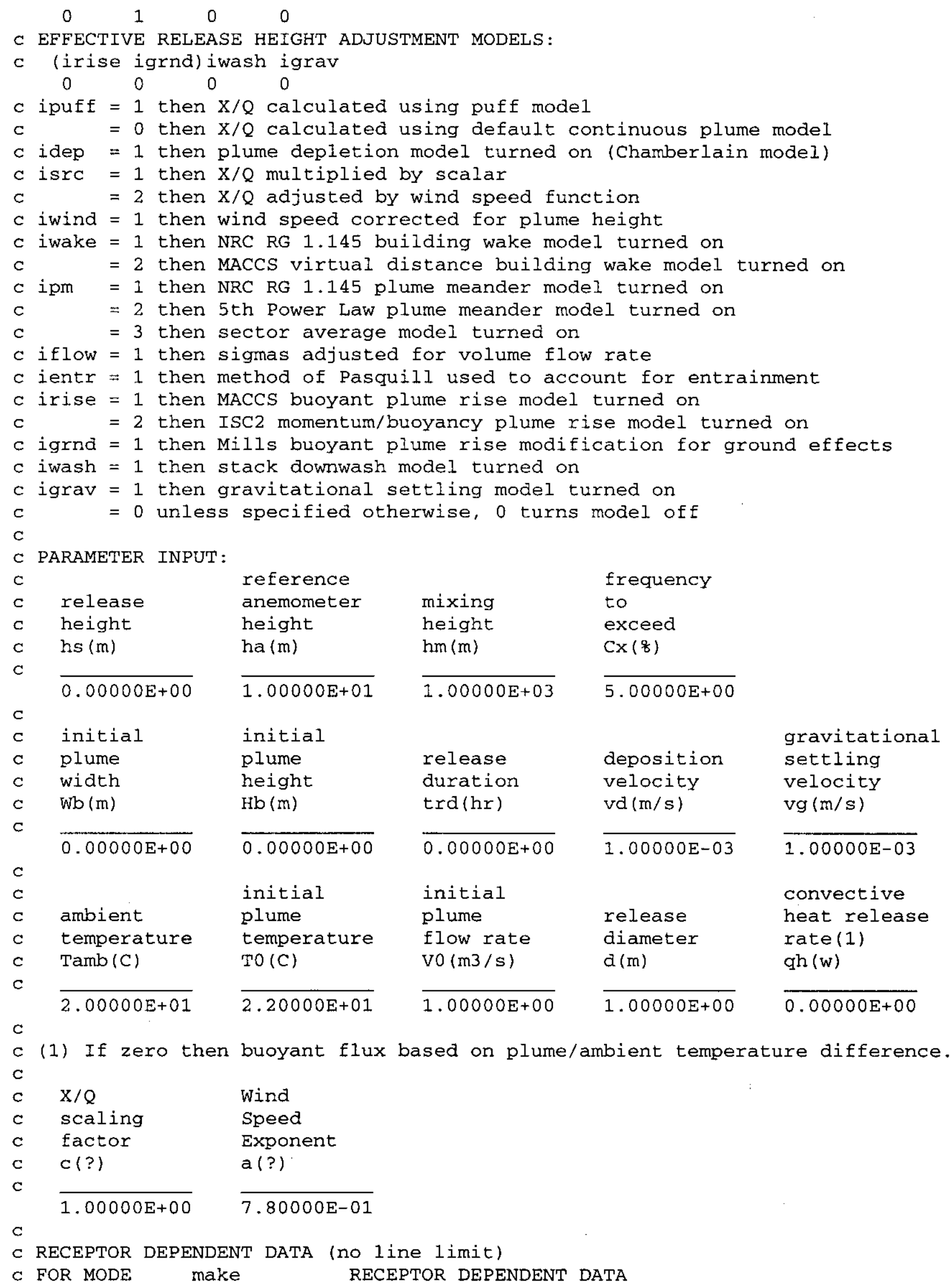




\section{RPP-5924 REV 0}

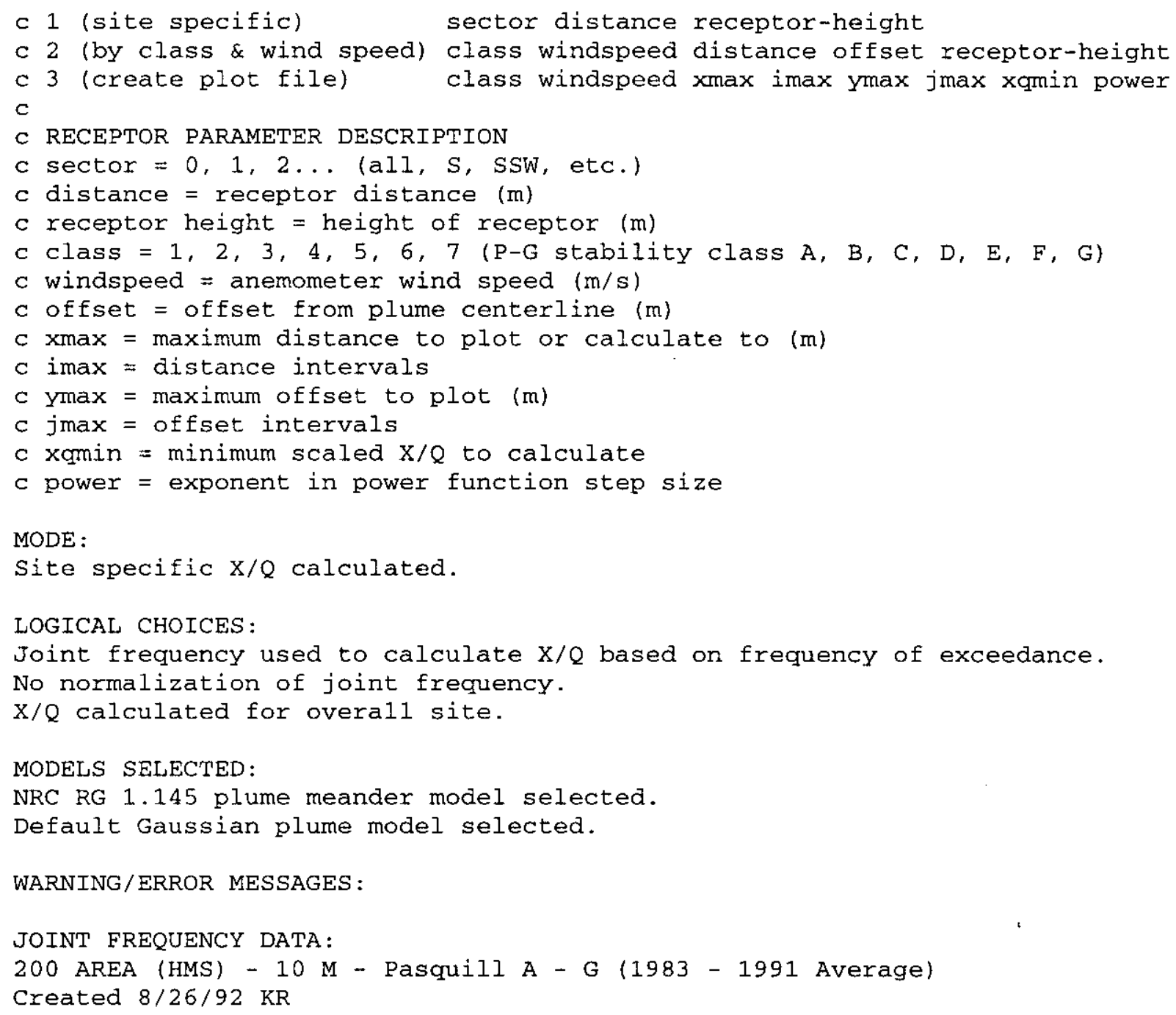

TWRS FSAR $95 \%$ overall river bd Plume Meander, 45 degree sectors

\begin{tabular}{|c|c|c|c|c|c|c|c|c|}
\hline \multirow[b]{3}{*}{ SECTOR } & & & & & $\begin{array}{c}\text { TOTAL } \\
\text { POPULATION }\end{array}$ & $\begin{array}{l}\text { AVERAGE } \\
\text { INDIVIDUAL }\end{array}$ & & \\
\hline & & RECEPT & SECT. & & SCALED & SCALED & ATM. & WIND \\
\hline & $\begin{array}{l}\text { DISTANCE } \\
(\mathrm{m})\end{array}$ & $\begin{array}{l}\text { HEIGHT } \\
(\mathrm{m})\end{array}$ & $\begin{array}{c}\text { FREQ. } \\
(z)\end{array}$ & POPULATION & $\begin{array}{l}X / Q \\
\left(s / m^{3}\right)\end{array}$ & $\begin{array}{l}X / Q \\
(\mathrm{~s} / \mathrm{m} 3)\end{array}$ & $\begin{array}{l}\text { STAB. } \\
\text { CLASS }\end{array}$ & $\begin{array}{l}\text { SPEED } \\
(\mathrm{m} / \mathrm{s})\end{array}$ \\
\hline ALL & 100 & 0 & 99.94 & 1 & $9.40 \mathrm{E}-03$ & $9.40 \mathrm{E}-03$ & F & 0.89 \\
\hline ALL & 15360 & 0 & 99.94 & 1 & $1.74 \mathrm{E}-05$ & $1.74 \mathrm{E}-05$ & $\mathrm{~F}$ & 0.89 \\
\hline
\end{tabular}




\section{RPP-5924 REV 0}

Current Input File Name: twrs45r4.IN

GXQ Version 4.0

December 19,1994

Genera1 Purpose Atmospheric Dispersion Code Produced by Westinghouse Hanford Company

Users Guide documented in WHC-SD-GN-SWD-30002 Rev. 1. Validation documented in WHC-SD-GN-SWD-30003 Rev. 1. code Custodian is: Brit E. Hey

Westinghouse Hanford Company

P.O. Box 1970

Richland, WA 99352

(509) 376-2921

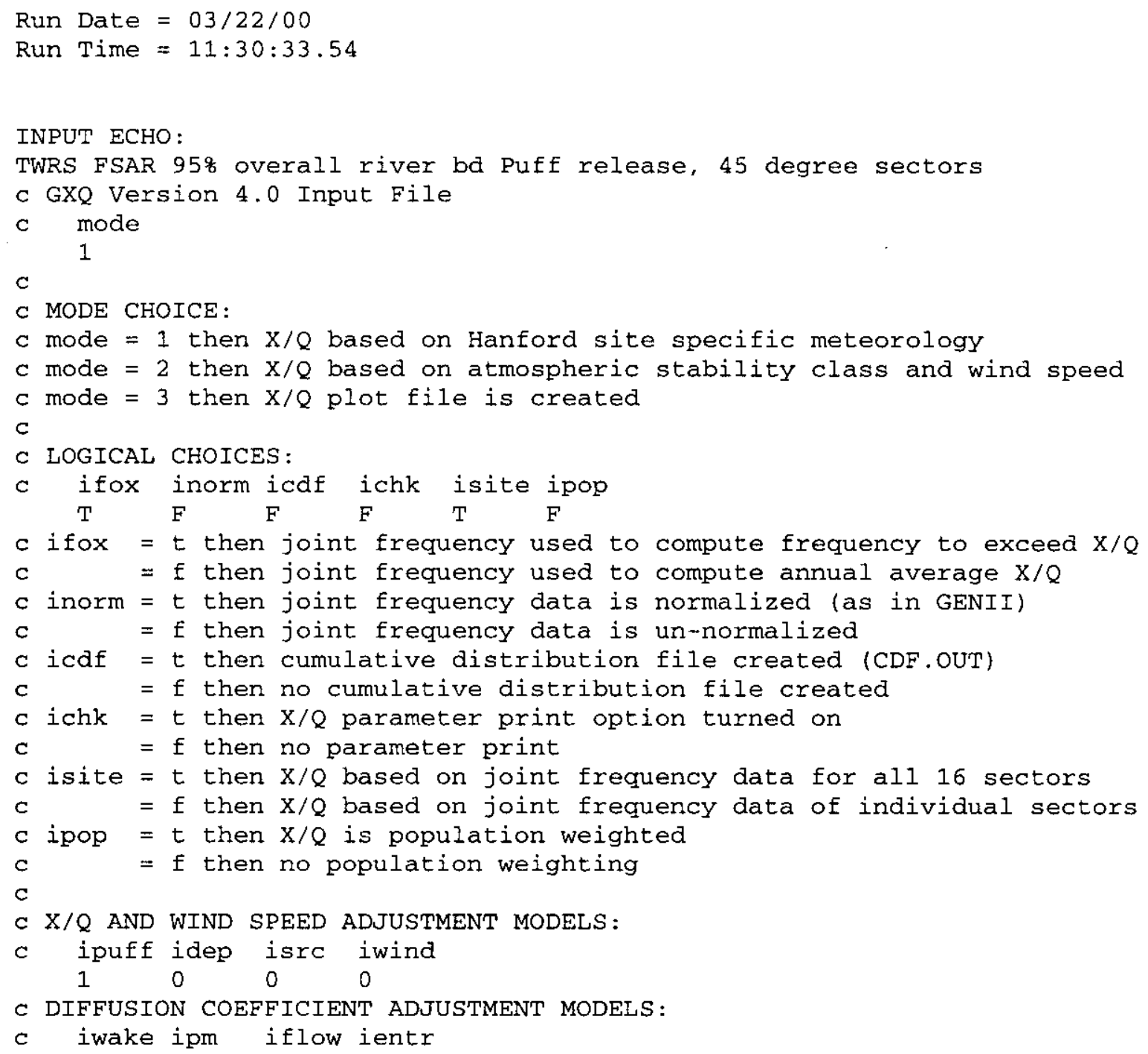




\section{RPP-5924 REV 0}

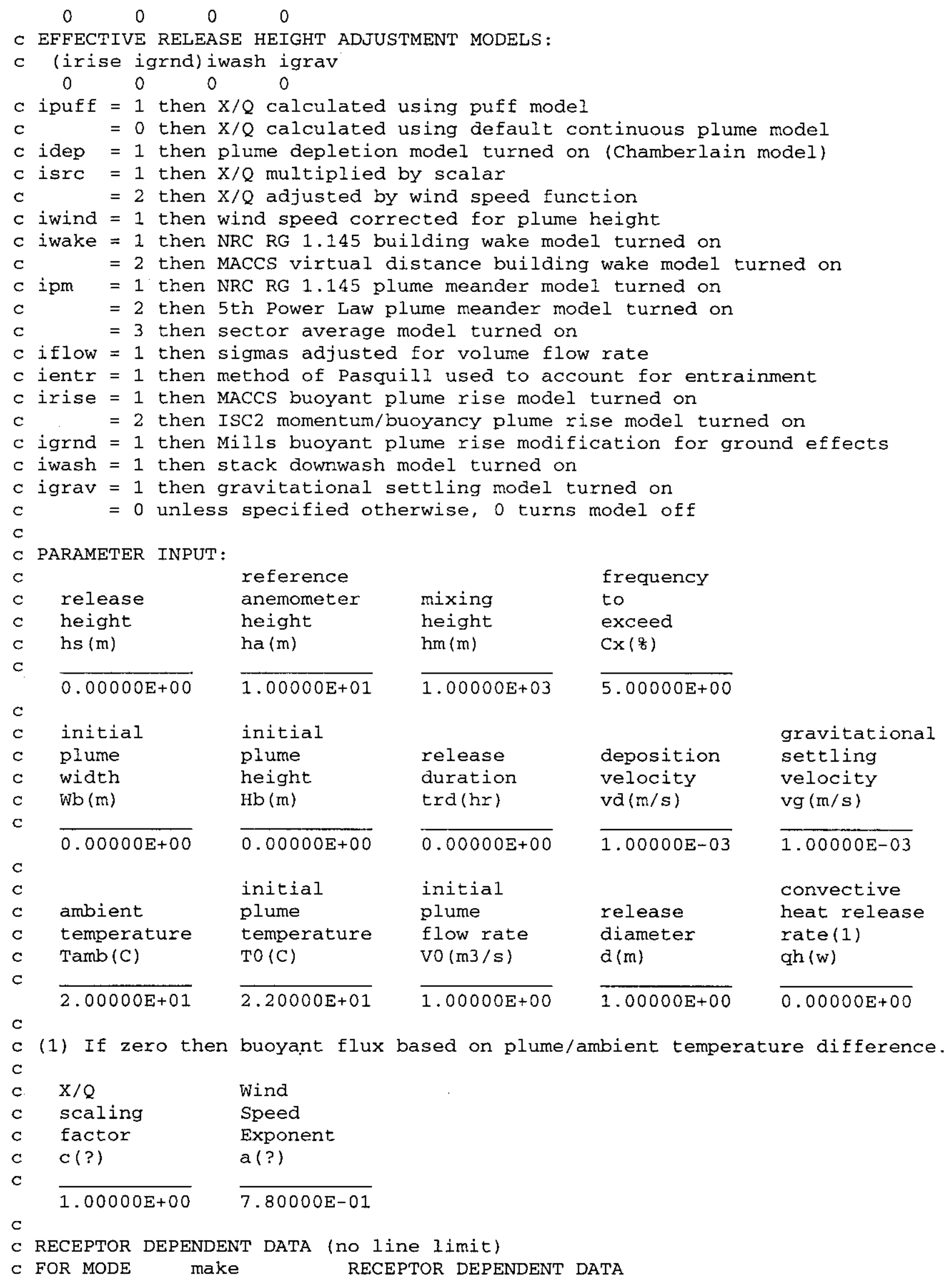




\section{RPP-5924 REV 0}

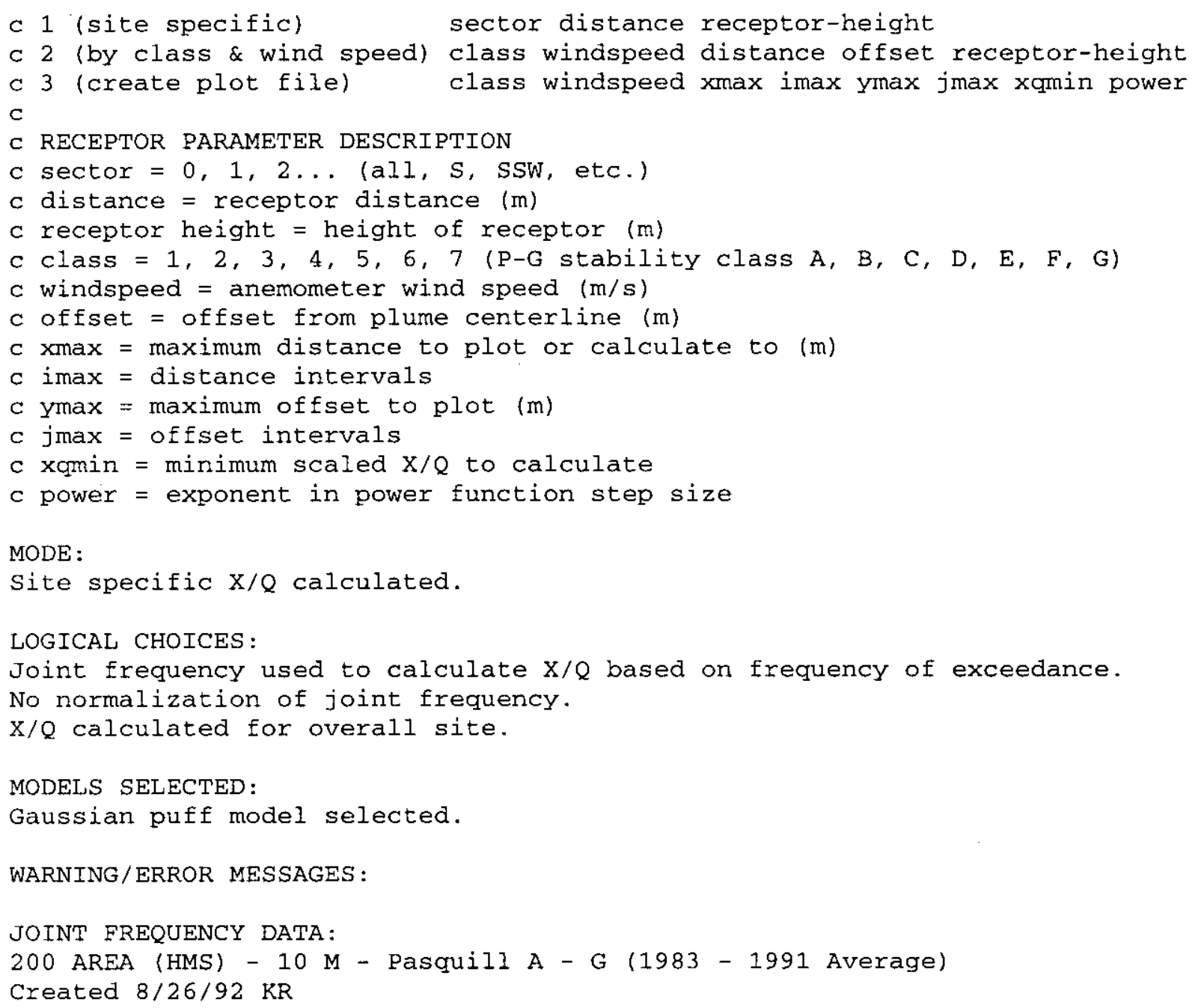

TWRS FSAR $95 \%$ overall river bd Puff release, 45 degree sectors

\begin{tabular}{|c|c|c|c|c|c|c|c|c|}
\hline & & & & & $\begin{array}{c}\text { TOTAL } \\
\text { POPULATION }\end{array}$ & $\begin{array}{l}\text { AVERAGE } \\
\text { INDIVIDUAL }\end{array}$ & & \\
\hline SECTOR & $\begin{array}{l}\text { DISTANCE } \\
(\mathrm{m})\end{array}$ & $\begin{array}{l}\text { RECEPT } \\
\text { HEIGHT } \\
\text { (m) }\end{array}$ & $\begin{array}{l}\text { SECT. } \\
\text { FREQ. } \\
(8)\end{array}$ & POPULATION & $\begin{array}{c}\text { SCALED } \\
\mathrm{X} / \mathrm{Q} \\
(1 / \mathrm{m} 3)\end{array}$ & $\begin{array}{c}\text { SCALED } \\
\mathrm{X} / \mathrm{Q} \\
(1 / \mathrm{m} 3)\end{array}$ & $\begin{array}{l}\text { ATM. } \\
\text { STAB. } \\
\text { CLASS }\end{array}$ & $\begin{array}{l}\text { WIND } \\
\text { SPEED } \\
\text { (m/s) }\end{array}$ \\
\hline & & & & + & $8.88 E-03$ & $8.88 E-03$ & G & \\
\hline ALL & 15360 & 0 & 99.94 & 1 & $5.06 \mathrm{E}-08$ & $5.06 \mathrm{E}-08$ & G & 0.8 \\
\hline
\end{tabular}


Current Input File Name: twrs $45 \times 5$. IN

GXQ Version 4.0

December 19, 1994

General Purpose Atmospheric Dispersion Code

Produced by Westinghouse Hanford Company

Users Guide documented in WHC-SD-GN-SWD-30002 Rev. 1.

Validation documented in WHC-SD-GN-SWD-30003 Rev. 1.

Code Custodian is: Brit E. Hey

Westinghouse Hanford Company

P.O. Box 1970

Richland, WA 99352

(509) 376-2921

Run Date $=03 / 15 / 00$

Run Time $=14: 38: 11.34$

INPUT ECHO:

TWRS FSAR river bd Annual Average, 45 degree sectors

c GXQ Version 4.0 Input File

C mode

1

$\mathrm{C}$

c MODE CHOICE:

$c$ mode $=1$ then $X / Q$ based on Hanford site specific meteorology

$c$ mode $=2$ then $X / Q$ based on atmospheric stability class and wind speed

$c$ mode $=3$ then $X / Q$ plot file is created

$\mathrm{c}$

c LOGICAL CHOICES:

c ifox inorm icdf ichk isite ipop

$\begin{array}{lllllll}F & F & F & F & F & F\end{array}$

$c$ ifox $=t$ then joint frequency used to compute frequency to exceed $x / Q$

$c=f$ then joint frequency used to compute annual average $X / Q$

$c$ inorm $=t$ then joint frequency data is normalized (as in GENII)

$c \quad=f$ then joint frequency data is un-normalized

c icdf $=t$ then cumulative distribution file created (CDF.OUT)

c $=\mathrm{E}$ then no cumulative distribution file created

$c$ ichk $=t$ then $X / Q$ parameter print option turned on

$c \quad=f$ then no parameter print

$c$ isite $=t$ then $X / Q$ based on joint frequency data for all 16 sectors

$c \quad=f$ then $X / Q$ based on joint frequency data of individual sectors

$c$ ipop $=t$ then $X / Q$ is population weighted

$c=\mathrm{E}$ then no population weighting

C

C X/Q AND WIND SPEED ADJUSTMENT MODELS:

$C$ ipuff idep isrc iwind

00000

C DIFFUSION COEFFICIENT ADJUSTMENT MODELS:

C iwake ipm iflow ientr 


\section{RPP-5924 REV 0}

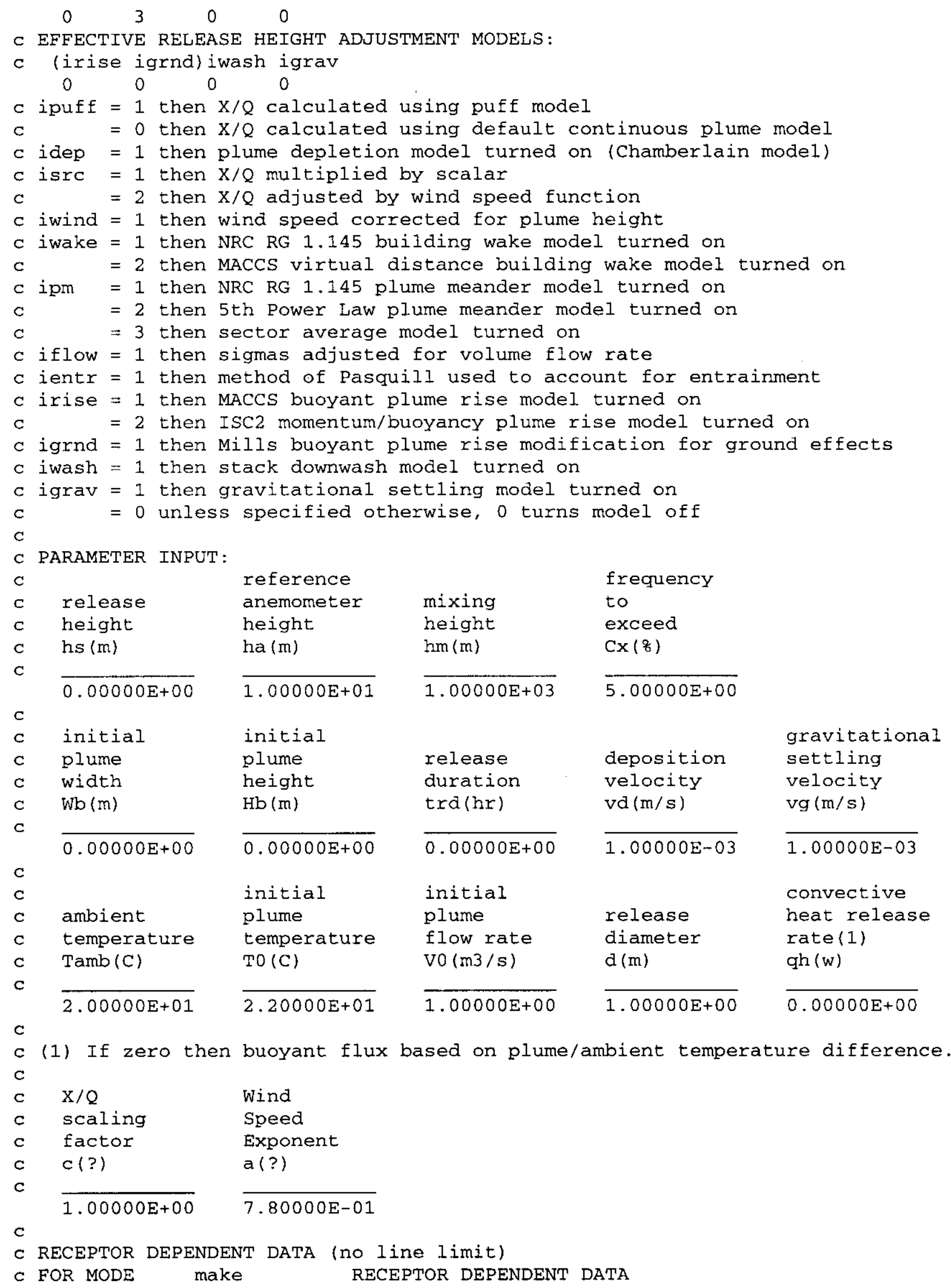




\section{RPP-5924 REV 0}

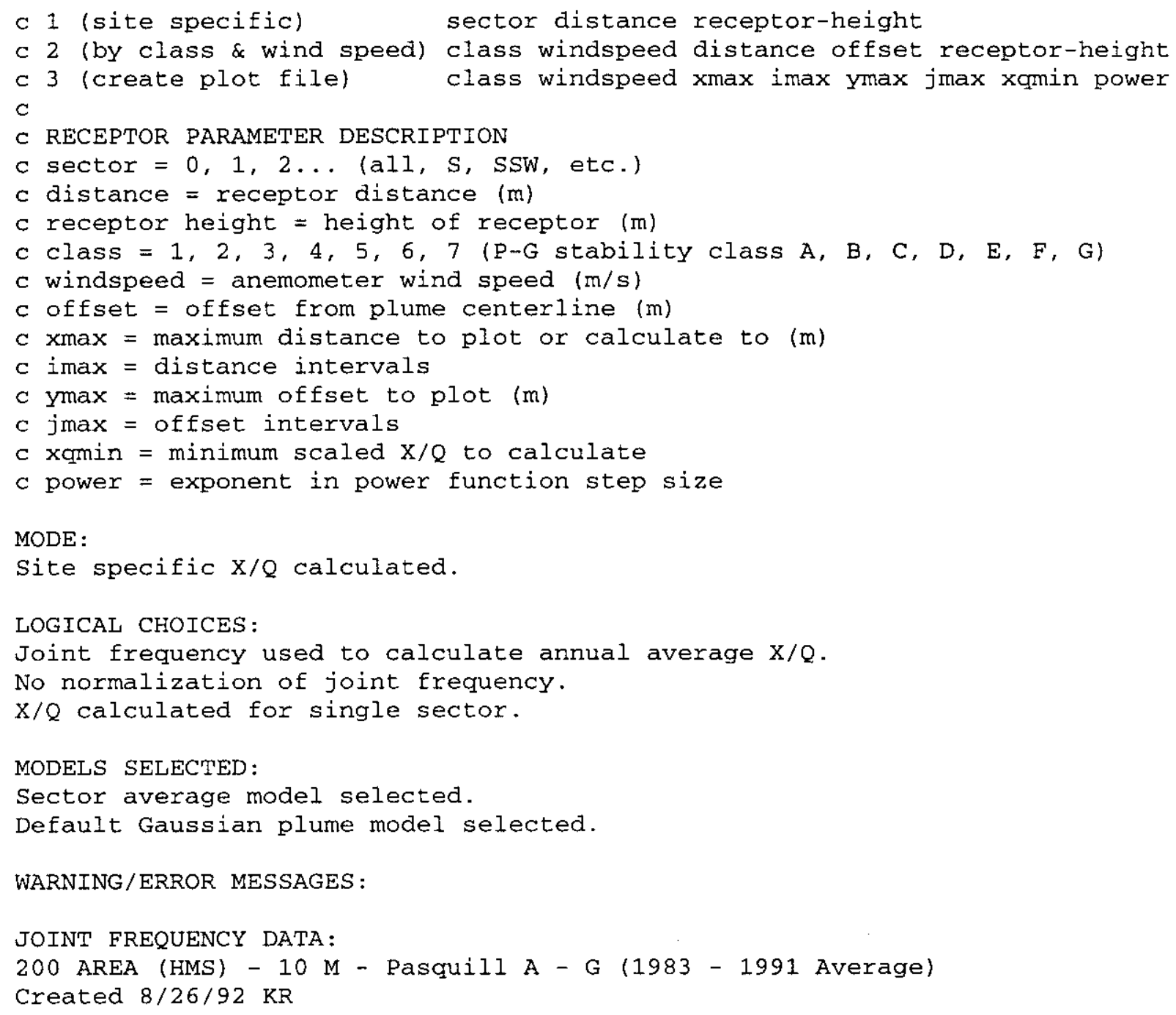

TWRS FSAR river bd Annual Average, 45 degree sectors

\begin{tabular}{|c|c|c|c|c|c|c|c|c|}
\hline SECTOR & $\begin{array}{l}\text { DISTANCE } \\
(\mathrm{m})\end{array}$ & $\begin{array}{l}\text { RECEPT } \\
\text { HEIGHT } \\
\text { (m) }\end{array}$ & $\begin{array}{l}\text { SECT. } \\
\text { FREQ. } \\
(8)\end{array}$ & POPULATION & $\begin{array}{c}\text { TOTAL } \\
\text { POPULATION } \\
\text { SCALED } \\
\text { X/Q } \\
(\mathrm{s} / \mathrm{m} 3)\end{array}$ & $\begin{array}{c}\text { AVERAGE } \\
\text { INDIVIDUAL } \\
\text { SCALED } \\
X / Q \\
(\mathrm{~s} / \mathrm{m} 3)\end{array}$ & $\begin{array}{l}\text { ATM. } \\
\text { STAB. } \\
\text { CLASS }\end{array}$ & $\begin{array}{l}\text { WIND } \\
\text { SPEED } \\
(\mathrm{m} / \mathrm{s})\end{array}$ \\
\hline$S$ & 100 & 0 & 6.30 & 1 & $1.68 \mathrm{E}-04$ & $1.68 \mathrm{E}-04$ & & \\
\hline SSW & 100 & 0 & 4.53 & 1 & $1.04 \mathrm{E}-04$ & $1.04 \mathrm{E}-04$ & & \\
\hline SW & 100 & 0 & 2.93 & 1 & $9.93 \mathrm{E}-05$ & $9.93 E-05$ & & \\
\hline WSW & 100 & 0 & 2.72 & 1 & $9.97 E-05$ & $9.97 E-05$ & & \\
\hline$w$ & 100 & 0 & 4.80 & 1 & $1.73 \mathrm{E}-04$ & $1.73 E-04$ & & \\
\hline WNW & 100 & 0 & 3.98 & 1 & $1.39 \mathrm{E}-04$ & $1.39 \mathrm{E}-04$ & & \\
\hline NW & 100 & 0 & 4.72 & 1 & $1.57 \mathrm{E}-04$ & $1.57 \mathrm{E}-04$ & & \\
\hline NNW & 100 & 0 & 4.58 & 1 & 1. $54 \mathrm{E}-04$ & $1.54 \mathrm{E}-04$ & & \\
\hline $\mathrm{N}$ & 100 & 0 & 4.36 & 1 & $1.61 \mathrm{E}-04$ & $1.61 \mathrm{E}-04$ & & \\
\hline NNE & 100 & 0 & 2.49 & 1 & $9.04 \mathrm{E}-05$ & $9.04 \mathrm{E}-05$ & & \\
\hline $\mathrm{NE}$ & 100 & 0 & 3.90 & 1 & $1.07 \mathrm{E}-04$ & $1.07 \mathrm{E}-04$ & & \\
\hline
\end{tabular}




\section{RPP-5924 REV 0}

$\begin{array}{lr}\text { ENE } & 100 \\ \text { E } & 100 \\ \text { ESE } & 100 \\ \text { SE } & 100 \\ \text { SSE } & 100 \\ \text { S } & 15360 \\ \text { SSW } & 15360 \\ \text { SW } & 13200 \\ \text { WSW } & 11100 \\ \text { W } & 11100 \\ \text { WNW } & 11100 \\ \text { NW } & 10800 \\ \text { NNW } & 8690 \\ \text { N } & 8690 \\ \text { NNE } & 8970 \\ \text { NE } & 10430 \\ \text { ENE } & 10530 \\ \text { E } & 11160 \\ \text { ESE } & 15190 \\ \text { SE } & 21050 \\ \text { SSE } & 15360\end{array}$

$\begin{array}{rr}0 & 6.17 \\ 0 & 14.05 \\ 0 & 18.80 \\ 0 & 10.83 \\ 0 & 4.78 \\ 0 & 6.30 \\ 0 & 4.53 \\ 0 & 2.93 \\ 0 & 2.72 \\ 0 & 4.80 \\ 0 & 3.98 \\ 0 & 4.72 \\ 0 & 4.58 \\ 0 & 4.36 \\ 0 & 2.49 \\ 0 & 3.90 \\ 0 & 6.17 \\ 0 & 14.05 \\ 0 & 18.80 \\ 0 & 10.83 \\ 0 & 4.78\end{array}$

$\begin{array}{lll}1 & 1.42 \mathrm{E}-04 & 1.42 \mathrm{E}-04 \\ 1 & 3.78 \mathrm{E}-04 & 3.78 \mathrm{E}-04 \\ 1 & 4.03 \mathrm{E}-04 & 4.03 \mathrm{E}-04 \\ 1 & 2.52 \mathrm{E}-04 & 2.52 \mathrm{E}-04 \\ 1 & 1.47 \mathrm{E}-04 & 1.47 \mathrm{E}-04 \\ 1 & 3.50 \mathrm{E}-08 & 3.50 \mathrm{E}-08 \\ 1 & 2.10 \mathrm{E}-08 & 2.10 \mathrm{E}-08 \\ 1 & 2.57 \mathrm{E}-08 & 2.57 \mathrm{E}-08 \\ 1 & 3.30 \mathrm{E}-08 & 3.30 \mathrm{E}-08 \\ 1 & 5.94 \mathrm{E}-08 & 5.94 \mathrm{E}-08 \\ 1 & 4.91 \mathrm{E}-08 & 4.91 \mathrm{E}-08 \\ 1 & 5.95 \mathrm{E}-08 & 5.95 \mathrm{E}-08 \\ 1 & 8.25 \mathrm{E}-08 & 8.25 \mathrm{E}-08 \\ 1 & 8.76 \mathrm{E}-08 & 8.76 \mathrm{E}-08 \\ 1 & 4.67 \mathrm{E}-08 & 4.67 \mathrm{E}-08 \\ 1 & 4.44 \mathrm{E}-08 & 4.44 \mathrm{E}-08 \\ 1 & 5.83 \mathrm{E}-08 & 5.83 \mathrm{E}-08 \\ 1 & 1.47 \mathrm{E}-07 & 1.47 \mathrm{E}-07 \\ 1 & 1.00 \mathrm{E}-07 & 1.00 \mathrm{E}-07 \\ 1 & 3.78 \mathrm{E}-08 & 3.78 \mathrm{E}-08 \\ 1 & 3.22 \mathrm{E}-08 & 3.22 \mathrm{E}-08\end{array}$




\section{RPP-5924 REV 0}

Current Input File Name: twrs45r6. IN

GXQ Version 4.0

December 19,1994

General Purpose Atmospheric Dispersion Code

Produced by Westinghouse Hanford Company

Users Guide documented in WHC-SD-GN-SWD-30002 Rev. 1.

Validation documented in WHC-SD-GN-SWD-30003 Rev. 1.

Code Custodian is: Brit E. Hey

Westinghouse Hanford Company

P.O. Box 1970

Richland, WA 99352

(509) 376-2921

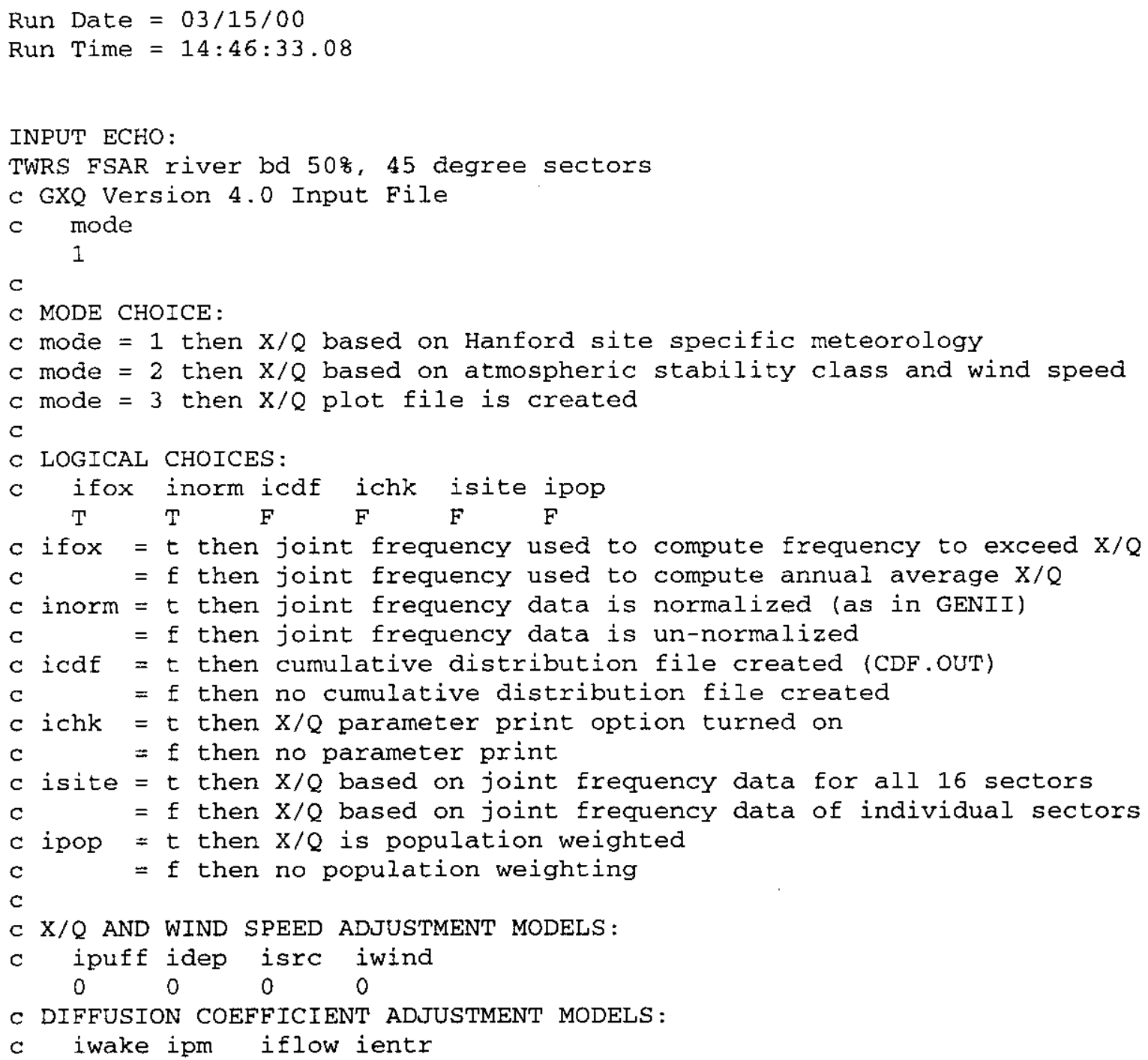




\section{RPP-5924 REV 0}

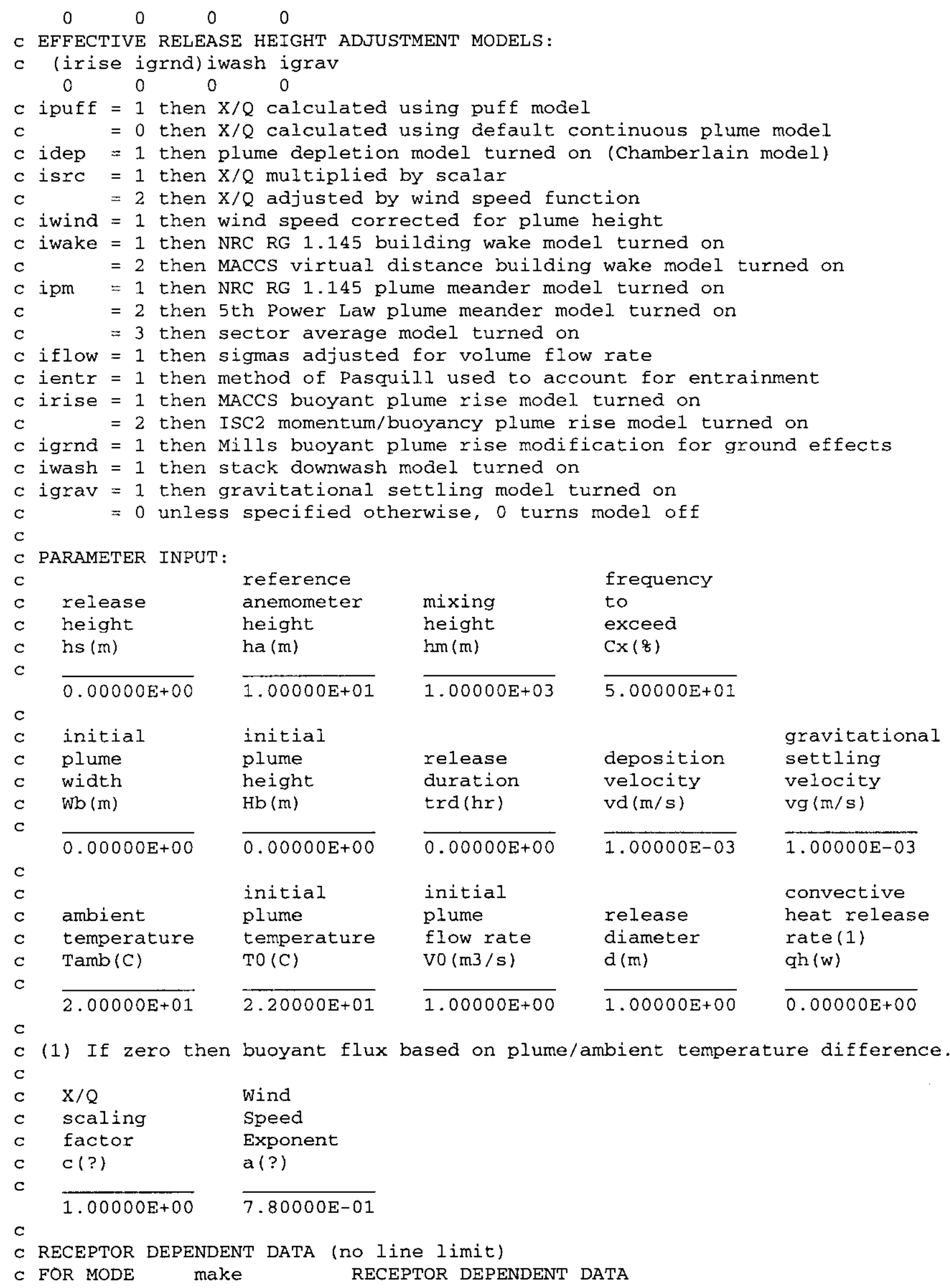




\section{RPP-5924 REV 0}

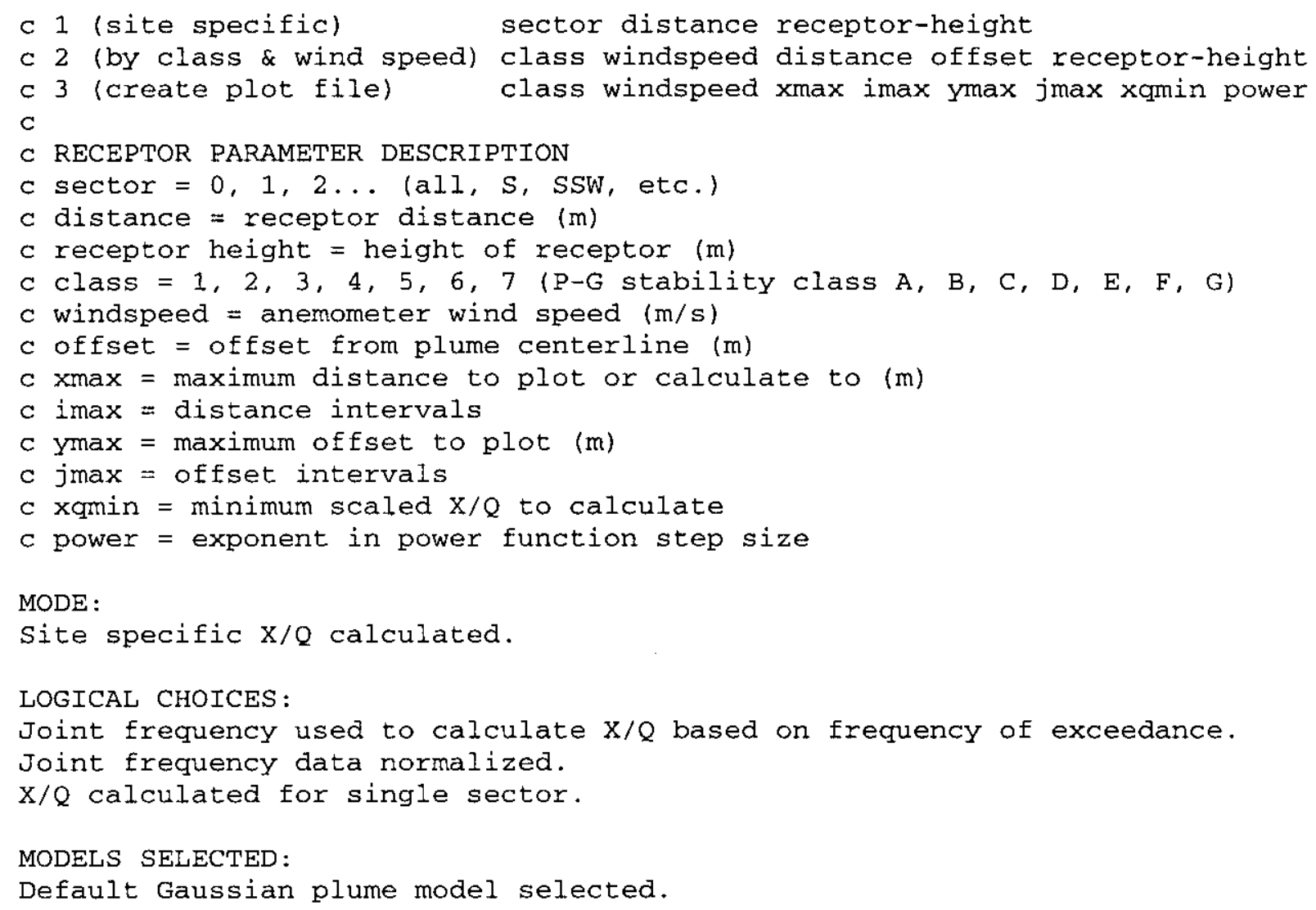

TWRS FSAR river bd 50\%, 45 degree sectors

\begin{tabular}{|c|c|c|c|c|c|c|c|c|}
\hline SECTOR & $\begin{array}{l}\text { DISTANCE } \\
(\mathrm{m})\end{array}$ & $\begin{array}{l}\text { RECEPT } \\
\text { HEIGHT } \\
\text { (m) }\end{array}$ & $\begin{array}{l}\text { SECT. } \\
\text { FREQ. } \\
(8)\end{array}$ & POPULATION & $\begin{array}{l}\text { TOTAL } \\
\text { POPULATION } \\
\text { SCALED } \\
\text { X/Q } \\
(\mathrm{s} / \mathrm{m} 3)\end{array}$ & $\begin{array}{c}\text { AVERAGE } \\
\text { INDIVIDUAL } \\
\text { SCALED } \\
X / Q \\
(\mathrm{~s} / \mathrm{m} 3)\end{array}$ & $\begin{array}{l}\text { ATM. } \\
\text { STAB. } \\
\text { CLASS }\end{array}$ & $\begin{array}{l}\text { WIND } \\
\text { SPEED } \\
(\mathrm{m} / \mathrm{s})\end{array}$ \\
\hline$S$ & 100 & 0 & 100.00 & 1 & $2.35 \mathrm{E}-03$ & $2.35 E-03$ & F & 15.60 \\
\hline SSW & 100 & 0 & 100.00 & 1 & $1.73 \mathrm{E}-03$ & $1.73 E-03$ & F & 19.00 \\
\hline SW & 100 & 0 & 100.00 & 1 & $2.86 \mathrm{E}-03$ & $2.86 \mathrm{E}-03$ & $E$ & 4.70 \\
\hline WSW & 100 & 0 & 100.00 & 1 & $3.36 \mathrm{E}-03$ & $3.36 \mathrm{E}-03$ & C & 0.89 \\
\hline W & 100 & 0 & 100.00 & 1 & $2.97 \mathrm{E}-03$ & $2.97 E-03$ & $\mathrm{E}$ & 4.70 \\
\hline WNW & 100 & 0 & 100.00 & 1 & $3.07 \mathrm{E}-03$ & $3.07 E-03$ & $E$ & 4.70 \\
\hline NW & 100 & 0 & 100.00 & 1 & $3.19 \mathrm{E}-03$ & $3.19 \mathrm{E}-03$ & $E$ & 4.70 \\
\hline NNW & 100 & 0 & 100.00 & 1 & $4.92 \mathrm{E}-03$ & $4.92 \mathrm{E}-03$ & $\mathrm{E}$ & 2.65 \\
\hline $\mathrm{N}$ & 100 & 0 & 100.00 & 1 & $5.33 \mathrm{E}-03$ & $5.33 E-03$ & $E$ & 2.65 \\
\hline NNE & 100 & 0 & 100.00 & 1 & $3.91 \mathrm{E}-03$ & $3.91 \mathrm{E}-03$ & C & 0.89 \\
\hline NE & 100 & 0 & 100.00 & 1 & $2.41 \mathrm{E}-03$ & $2.41 \mathrm{E}-03$ & $D$ & 2.65 \\
\hline ENE & 100 & 0 & 100.00 & 1 & $1.98 \mathrm{E}-03$ & $1.98 E-03$ & $E$ & 7.15 \\
\hline
\end{tabular}




\section{RPP-5924 REV 0}

\begin{tabular}{|c|c|c|c|}
\hline$E$ & 100 & 0 & 100.00 \\
\hline ESE & 100 & 0 & 100.00 \\
\hline SE & 100 & 0 & 100.00 \\
\hline SSE & 100 & 0 & 100.00 \\
\hline S & 15360 & 0 & 100.00 \\
\hline SSW & 15360 & 0 & 100.00 \\
\hline SW & 13200 & 0 & 100.00 \\
\hline WSW & 11100 & 0 & 100.00 \\
\hline W & 11100 & 0 & 100.00 \\
\hline WNW & 11100 & 0 & 100.00 \\
\hline NW & 10800 & 0 & 100.00 \\
\hline NNW & 8690 & 0 & 100.00 \\
\hline $\mathrm{N}$ & 8690 & 0 & 100.00 \\
\hline NNE & 8970 & 0 & 100.00 \\
\hline $\mathrm{NE}$ & 10430 & 0 & 100.00 \\
\hline ENE & 10530 & 0 & 100.00 \\
\hline $\mathrm{E}$ & 11160 & 0 & 100.00 \\
\hline ESE & 15190 & 0 & 100.00 \\
\hline $\mathrm{SE}$ & 21050 & 0 & 100.00 \\
\hline SSE & 15360 & 0 & 100.00 \\
\hline
\end{tabular}

$\begin{array}{ll}1 & 4.65 \mathrm{E}-03 \\ 1 & 2.89 \mathrm{E}-03 \\ 1 & 2.81 \mathrm{E}-03 \\ 1 & 2.86 \mathrm{E}-03 \\ 1 & 7.65 \mathrm{E}-07 \\ 1 & 4.50 \mathrm{E}-07 \\ 1 & 1.06 \mathrm{E}-06 \\ 1 & 1.56 \mathrm{E}-06 \\ 1 & 1.59 \mathrm{E}-06 \\ 1 & 1.65 \mathrm{E}-06 \\ 1 & 1.82 \mathrm{E}-06 \\ 1 & 4.24 \mathrm{E}-06 \\ 1 & 4.48 \mathrm{E}-06 \\ 1 & 3.18 \mathrm{E}-06 \\ 1 & 1.33 \mathrm{E}-06 \\ 1 & 1.25 \mathrm{E}-06 \\ 1 & 2.96 \mathrm{E}-06 \\ 1 & 1.13 \mathrm{E}-06 \\ 1 & 5.11 \mathrm{E}-07 \\ 1 & 9.36 \mathrm{E}-07\end{array}$

4. $65 \mathrm{E}-03 \mathrm{~F}$

7.15

2. $89 \mathrm{E}-03 \mathrm{E}$

4.70

$2.81 \mathrm{E}-03 \mathrm{D}$

2.65

4.70

$2.86 \mathrm{E}-03 \mathrm{E}$

7.15

4. 50E-07 D

4.70

1. $06 \mathrm{E}-06 \mathrm{D}$

2.65

4.70

4.70

1. $59 \mathrm{E}-06 \mathrm{E}$

1. $65 \mathrm{E}-06 \mathrm{E}$

4.70

1. $82 \mathrm{E}-06 \mathrm{E}$

4.70

4. $24 \mathrm{E}-06 \mathrm{E}$

2.65

2.65

4.70

3.18E-06 E

7.15

7.15

7.15

4.70

2.65

2.65 


\section{RPP-5924 REV 0}

Current Input File Name: twrs45r7.IN

GXQ Version 4.0

December 19, 1994

General Purpose Atmospheric Dispersion Code

Produced by Westinghouse Hanford Company

Users Guide documented in WHC-SD-GN-SWD-30002 Rev. 1.

Validation documented in WHC-SD-GN-SWD-30003 Rev. 1.

Code Custodian is: Brit E. Hey

Westinghouse Hanford Company

P.O. Box 1970

Richland, WA 99352

(509) 376-2921

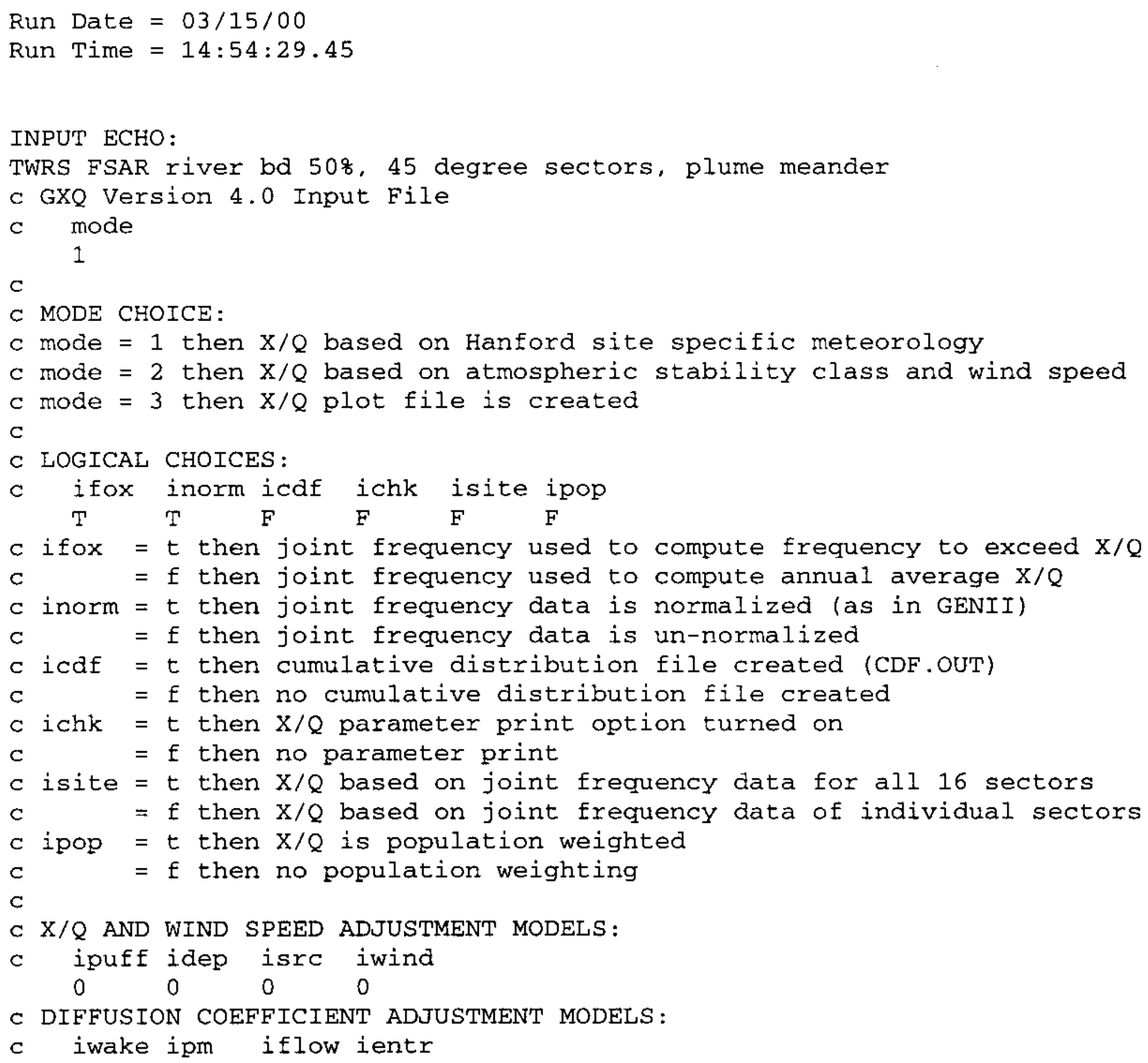




\section{RPP-5924 REV 0}

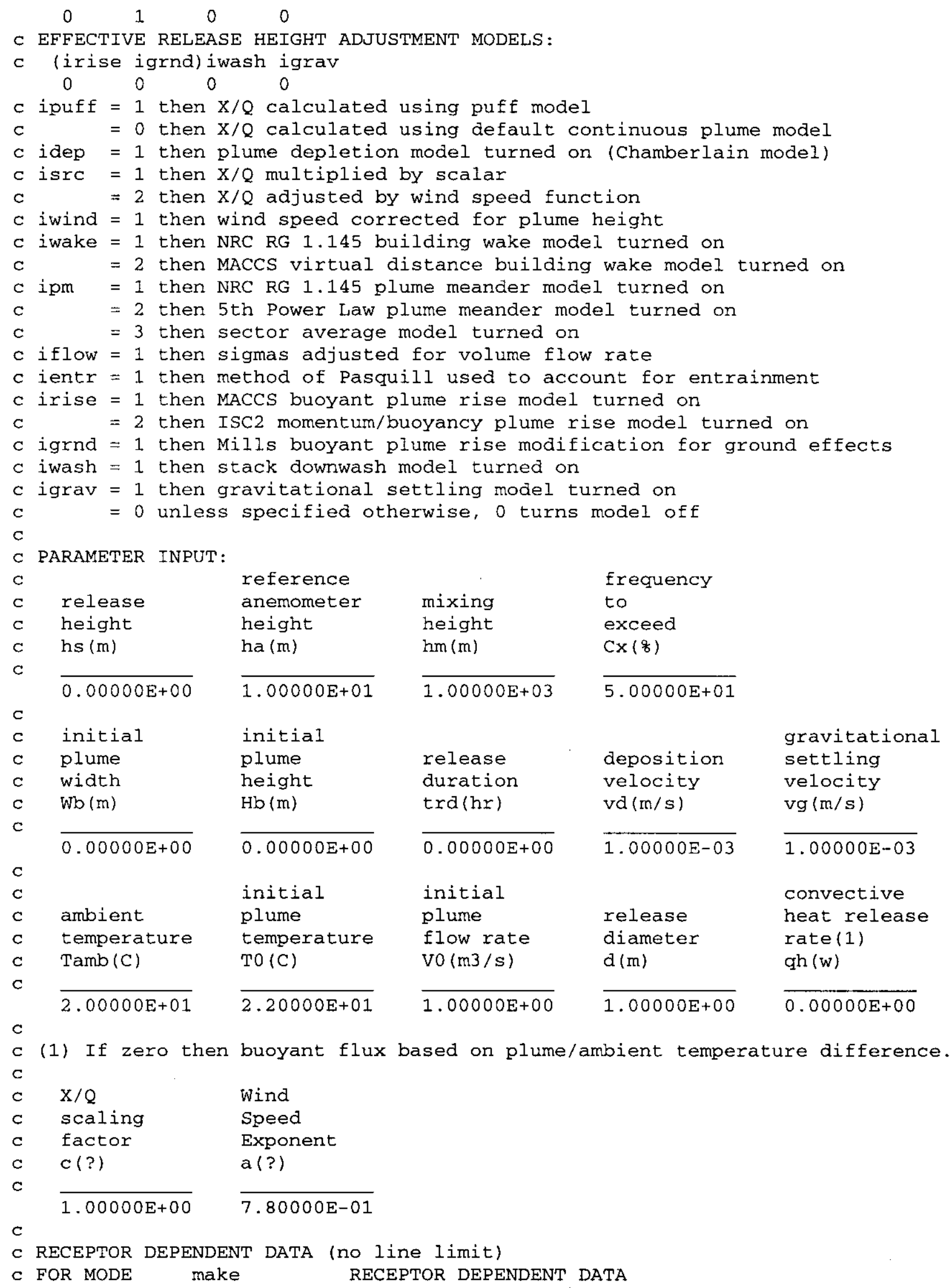




\title{
RPP-5924 REV 0
}

\author{
c 1 (site specific) \\ sector distance receptor-height \\ c 2 (by class \& wind speed) \\ c 3 (create plot file) \\ class windspeed distance offset receptor-height \\ $\mathrm{C}$ \\ C RECEPTOR PARAMETER DESCRIPTION \\ c sector $=0,1,2 \ldots($ all, S, SSW, etc. $)$ \\ c distance $=$ receptor distance $(\mathrm{m})$ \\ c receptor height $=$ height of receptor $(\mathrm{m})$ \\ c class $=1,2,3,4,5,6,7$ (P-G stability class A, B, C, D, E, F, G) \\ C windspeed $=$ anemometer wind speed $(\mathrm{m} / \mathrm{s})$ \\ $c$ offset $=$ offset from plume centerline $(\mathrm{m})$ \\ $c \operatorname{xmax}=$ maximum distance to plot or calculate to $(\mathrm{m})$ \\ c $i \max =$ distance intervals \\ c $y \max =$ maximum offset to plot $(\mathrm{m})$ \\ c jmax $=$ offset intervals \\ c $x q m i n=$ minimum scaled $x / Q$ to calculate \\ $c$ power $=$ exponent in power function step size \\ MODE: \\ Site specific $X / Q$ calculated. \\ LOGICAL CHOICES: \\ Joint frequency used to calculate $X / Q$ based on frequency of exceedance. \\ Joint frequency data normalized. \\ $\mathrm{X} / \mathrm{Q}$ calculated for single sector. \\ MODELS SELECTED: \\ NRC RG 1.145 plume meander model selected. \\ Default Gaussian plume model selected. \\ WARNING/ERROR MESSAGES: \\ JOINT FREQUENCY DATA: \\ 200 AREA (HMS) - 10 M - Pasquill A - G (1983 - 1991 Average) \\ Created $8 / 26 / 92 \mathrm{KR}$
}

TWRS FSAR river bd 50\%, 45 degree sectors, plume meander

\begin{tabular}{|c|c|c|c|c|c|c|c|c|}
\hline SECTOR & $\begin{array}{l}\text { DISTANCE } \\
\text { (m) }\end{array}$ & $\begin{array}{l}\text { RECEPT } \\
\text { HEIGHT } \\
\text { (m) }\end{array}$ & $\begin{array}{l}\text { SECT. } \\
\text { FREQ. } \\
(8)\end{array}$ & POPULATION & $\begin{array}{l}\text { TOTAL } \\
\text { POPULATION } \\
\text { SCALED } \\
X / Q \\
(\mathrm{~s} / \mathrm{m} 3)\end{array}$ & $\begin{array}{l}\text { AVERAGE } \\
\text { INDIVIDUAL } \\
\text { SCALED } \\
X / Q \\
(\mathrm{~s} / \mathrm{m} 3)\end{array}$ & $\begin{array}{l}\text { ATM. } \\
\text { STAB. } \\
\text { CLASS }\end{array}$ & $\begin{array}{l}\text { WIND } \\
\text { SPEED } \\
(\mathrm{m} / \mathrm{s})\end{array}$ \\
\hline $\mathrm{S}$ & 100 & 0 & 100.00 & 1 & $1.67 \mathrm{E}-03$ & $1.67 \mathrm{E}-03$ & D & 2.65 \\
\hline SSW & 100 & 0 & 100.00 & 1 & $1.62 \mathrm{E}-03$ & $1.62 \mathrm{E}-03$ & $\mathrm{~F}$ & 19.00 \\
\hline SW & 100 & 0 & 100.00 & 1 & $1.85 \mathrm{E}-03$ & $1.85 E-03$ & B & 0.89 \\
\hline WSW & 100 & 0 & 100.00 & 1 & $2.22 E-03$ & $2.22 \mathrm{E}-03$ & $E$ & 2.65 \\
\hline $\mathrm{W}$ & 100 & 0 & 100.00 & 1 & $2.07 E-03$ & $2.07 \mathrm{E}-03$ & $E$ & 2.65 \\
\hline WNW & 100 & 0 & 100.00 & 1 & $2.04 E-03$ & $2.04 E-03$ & B & 0.89 \\
\hline NW & 100 & 0 & 100.00 & 1 & $2.10 E-03$ & $2.10 E-03$ & $\mathrm{E}$ & 2.65 \\
\hline NNW & 100 & 0 & 100.00 & 1 & $2.27 E-03$ & $2.27 E-03$ & $E$ & 4.70 \\
\hline $\mathrm{N}$ & 100 & 0 & 100.00 & 1 & $2.27 E-03$ & $2.27 E-03$ & $\mathrm{E}$ & 4.70 \\
\hline NNE & 100 & 0 & 100.00 & 1 & $2.27 E-03$ & $2.27 E-03$ & $\mathrm{E}$ & 2.65 \\
\hline $\mathrm{NE}$ & 100 & 0 & 100.00 & 1 & $1.81 \mathrm{E}-03$ & $1.81 E-03$ & B & 0.89 \\
\hline
\end{tabular}




\section{RPP-5924 REV 0}

\begin{tabular}{|c|c|c|c|c|c|c|c|c|}
\hline ENE & 100 & 0 & 100.00 & 1 & $1.75 \mathrm{E}-03$ & $1.75 \mathrm{E}-03$ & D & 2.65 \\
\hline $\mathrm{E}$ & 100 & 0 & 100.00 & 1 & $2.27 E-03$ & $2.27 \mathrm{E}-03$ & $E$ & 4.70 \\
\hline ESE & 100 & 0 & 100.00 & 1 & $2.27 E-03$ & $2.27 \mathrm{E}-03$ & $\mathrm{E}$ & 2.65 \\
\hline $\mathrm{SE}$ & 100 & 0 & 100.00 & 1 & $1.87 \mathrm{E}-03$ & $1.87 \mathrm{E}-03$ & B & 0.89 \\
\hline SSE & 100 & 0 & 100.00 & 1 & $1.85 E-03$ & $1.85 \mathrm{E} \sim 03$ & B & 0.89 \\
\hline $\mathrm{S}$ & 15360 & 0 & 100.00 & 1 & $7.57 \mathrm{E}-07$ & $7.57 E-07$ & $E$ & 7.15 \\
\hline SSW & 15360 & 0 & 100.00 & 1 & $4.45 \mathrm{E}-07$ & $4.45 E-07$ & D & 4.70 \\
\hline SW & 13200 & 0 & 100.00 & 1 & $1.01 \mathrm{E}-06$ & $1.01 E-06$ & D & 2.65 \\
\hline WSW & 11100 & 0 & 100.00 & 1 & $1.50 \mathrm{E}-06$ & $1.50 \mathrm{E}-06$ & E & 4.70 \\
\hline W & 11100 & 0 & 100.00 & 1 & $1.54 \mathrm{E}-06$ & $1.54 \mathrm{E}-06$ & E & 4.70 \\
\hline WNW & 11100 & 0 & 100.00 & 1 & $1.59 \mathrm{E}-06$ & $1.59 \mathrm{E}-06$ & $E$ & 4.70 \\
\hline NW & 10800 & 0 & 100.00 & 1 & $1.77 \mathrm{E}-06$ & $1.77 \mathrm{E}-06$ & $E$ & 4.70 \\
\hline NNW & 8690 & 0 & 100.00 & 1 & $3.58 \mathrm{E}-06$ & $3.58 \mathrm{E}-06$ & $E$ & 2.65 \\
\hline $\mathrm{N}$ & 8690 & 0 & 100.00 & 1 & $3.83 E-06$ & $3.83 \mathrm{E}-06$ & $E$ & 2.65 \\
\hline NNE & 8970 & 0 & 100.00 & 1 & $2.91 \mathrm{E}-06$ & $2.91 \mathrm{E}-06$ & $E$ & 4.70 \\
\hline $\mathrm{NE}$ & 10430 & 0 & 100.00 & 1 & $1.29 E-06$ & $1.29 \mathrm{E}-06$ & $E$ & 7.15 \\
\hline ENE & 10530 & 0 & 100.00 & 1 & $1.25 \mathrm{E}-06$ & $1.25 \mathrm{E}-06$ & $E$ & 7.15 \\
\hline $\mathrm{E}$ & 11160 & 0 & 100.00 & 1 & $2.54 \mathrm{E}-06$ & $2.54 \mathrm{E}-06$ & $\mathrm{E}$ & 2.65 \\
\hline ESE & 15190 & 0 & 100.00 & 1 & $1.11 \mathrm{E}-06$ & $1.11 \mathrm{E}-06$ & $\mathrm{E}$ & 4.70 \\
\hline$S E$ & 21050 & 0 & 100.00 & 1 & $4.95 E-07$ & $4.95 E-07$ & $\mathrm{E}$ & 7.15 \\
\hline SSE & 15360 & 0 & 100.00 & 1 & $9.05 \mathrm{E}-07$ & $9.05 \mathrm{E}-07$ & D & 2.65 \\
\hline
\end{tabular}




\section{RPP-5924 REV 0}

Current Input File Name: twrs $45 \mathrm{r} 8$.IN

GXQ Version 4.0

December 19,1994

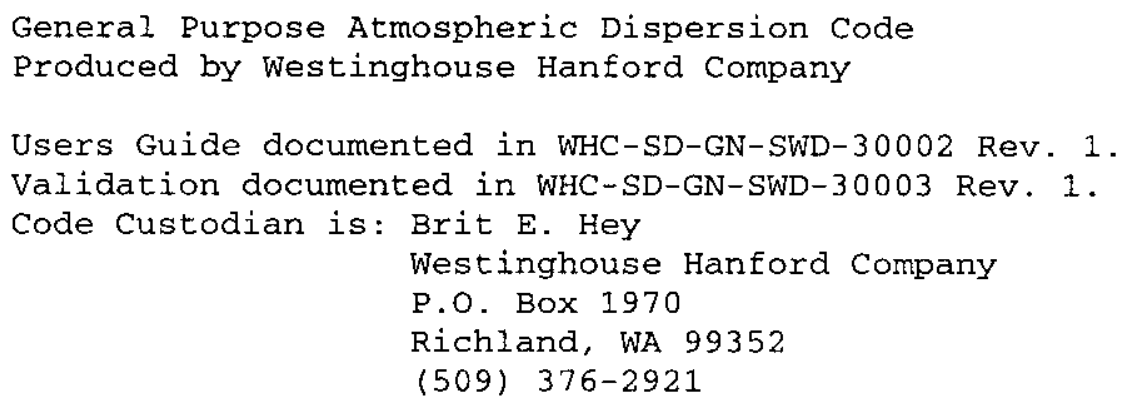




\section{RPP-5924 REV 0}

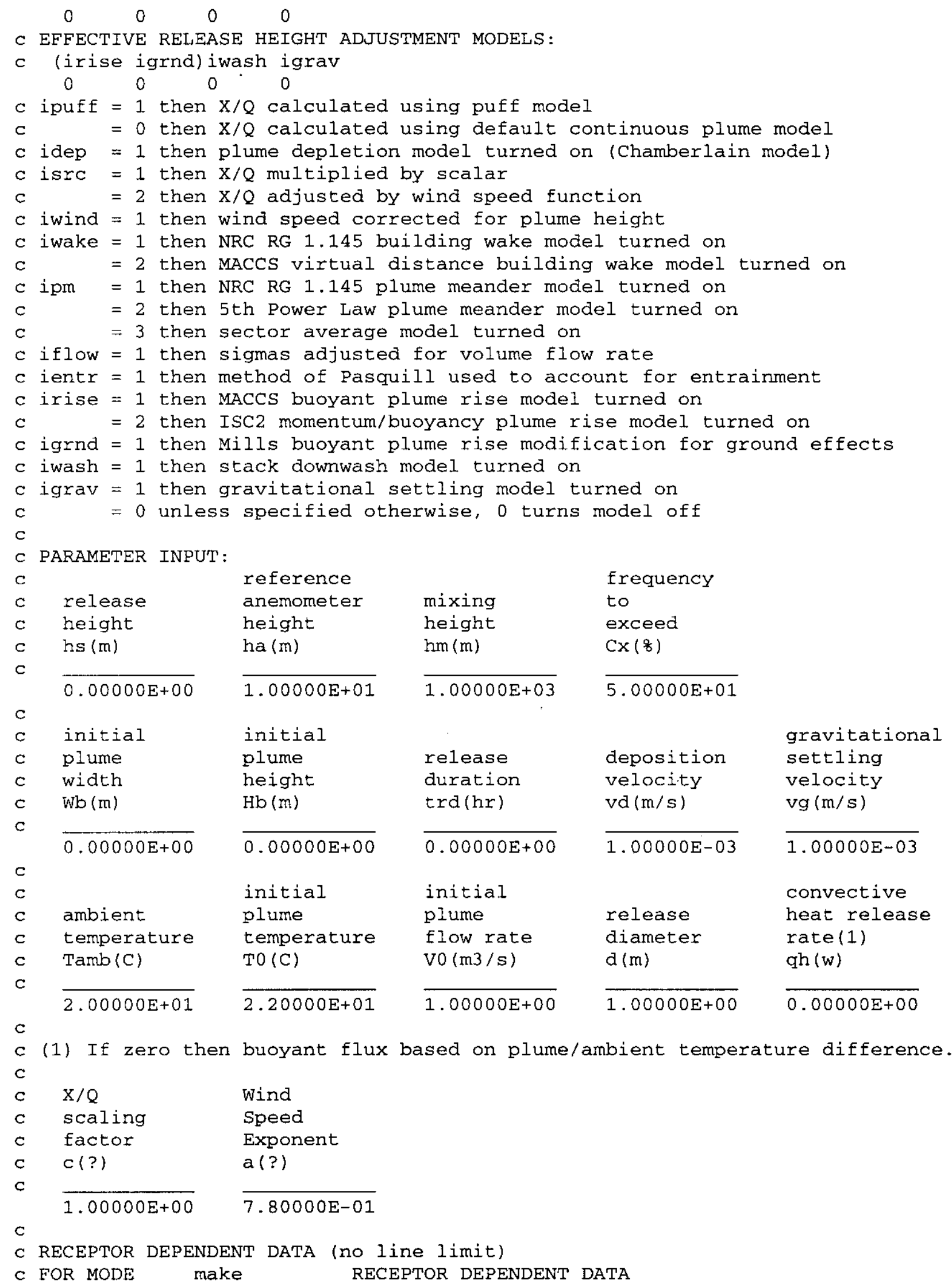




\section{RPP-5924 REV 0}

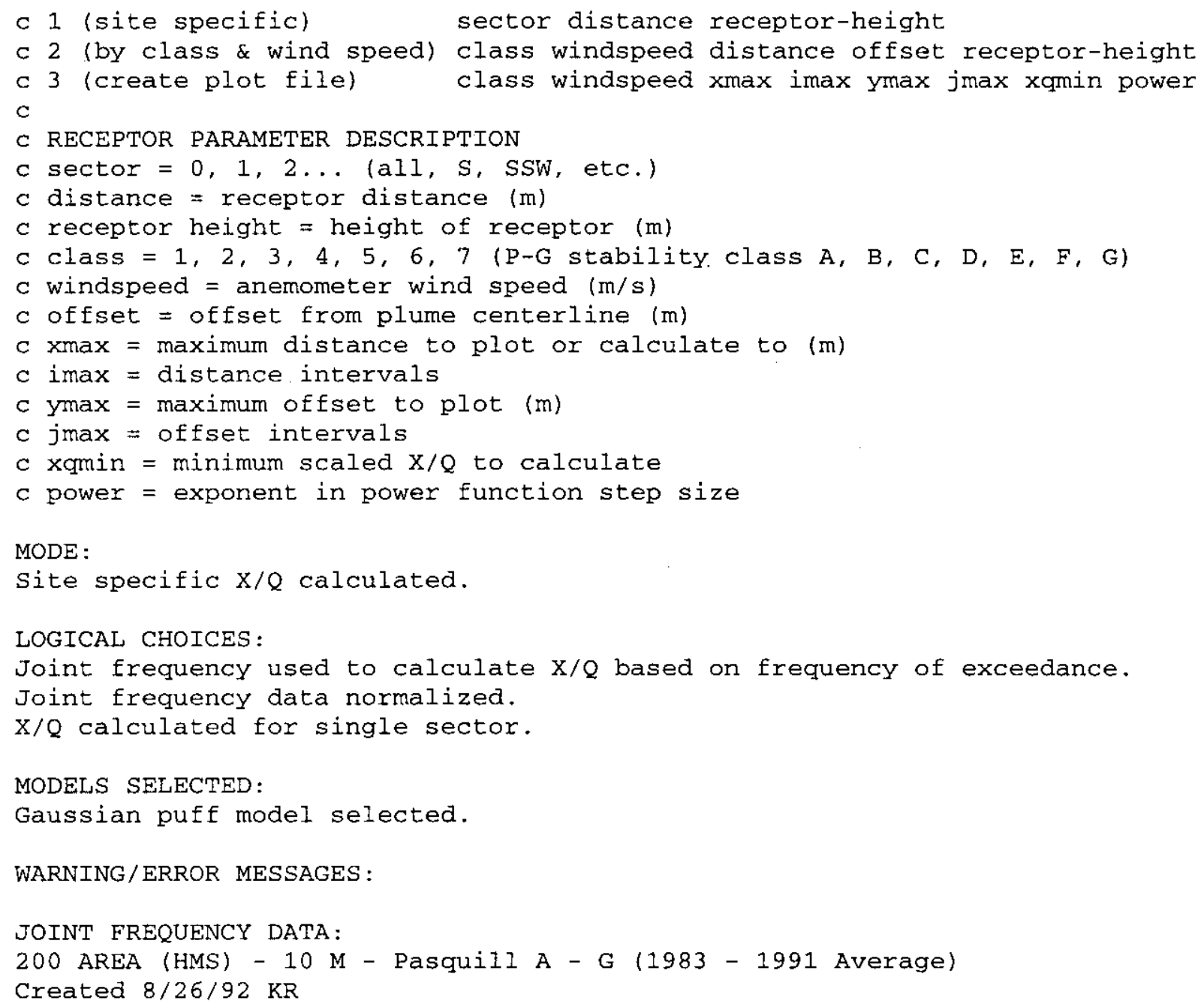

MODE :

Site specific $X / Q$ calculated.

LOGICAL CHOICES :

Joint frequency used to calculate $X / Q$ based on frequency of exceedance. Joint frequency data normalized.

$\mathrm{X} / \mathrm{Q}$ calculated for single sector.

MODELS SELECTED:

Gaussian puff model selected.

WARNING/ERROR MESSAGES:

JOINT FREQUENCY DATA:

200 AREA (HMS) - 10 M - Pasquill A - G (1983 - 1991 Average)

Created $8 / 26 / 92 \mathrm{KR}$

TWRS FSAR river bd 50\%, 45 degree sectors, puff

\begin{tabular}{|c|c|c|c|c|c|c|c|c|}
\hline SECTOR & $\begin{array}{l}\text { DISTANCE } \\
(\mathrm{m})\end{array}$ & $\begin{array}{l}\text { RECEPT } \\
\text { HEIGHT } \\
\text { (m) }\end{array}$ & $\begin{array}{l}\text { SECT. } \\
\text { FREQ. } \\
(8)\end{array}$ & POPULATION & $\begin{array}{l}\text { TOTAL } \\
\text { POPULATION } \\
\text { SCALED } \\
\text { X/Q } \\
(1 / \mathrm{m} 3)\end{array}$ & $\begin{array}{c}\text { AVERAGE } \\
\text { INDIVIDUAL } \\
\text { SCALED } \\
X / Q \\
(1 / \mathrm{m} 3)\end{array}$ & $\begin{array}{l}\text { ATM. } \\
\text { STAB. } \\
\text { CLASS }\end{array}$ & $\begin{array}{l}\text { WIND } \\
\text { SPEED } \\
(\mathrm{m} / \mathrm{s})\end{array}$ \\
\hline$S$ & 100 & 0 & 100.00 & 1 & $2.59 E-04$ & $2.59 \mathrm{E}-04$ & $\mathrm{D}$ & 2.65 \\
\hline SSW & 100 & 0 & 100.00 & 1 & $2.54 E-04$ & $2.54 \mathrm{E}-04$ & $\mathrm{D}$ & 2.65 \\
\hline SW & 100 & 0 & 100.00 & 1 & $2.59 E-04$ & $2.59 \mathrm{E}-04$ & $\mathrm{D}$ & 0.89 \\
\hline WSW & 100 & 0 & 100.00 & 1 & $2.50 E-04$ & $2.50 \mathrm{E}-04$ & $\mathrm{D}$ & 2.65 \\
\hline W & 100 & 0 & 100.00 & 1 & $2.92 \mathrm{E}-04$ & $2.92 \mathrm{E}-04$ & $\mathrm{D}$ & 2.65 \\
\hline WNW & 100 & 0 & 100.00 & 1 & $3.38 \mathrm{E}-04$ & $3.38 \mathrm{E}-04$ & $\mathrm{D}$ & 2.65 \\
\hline NW & 100 & 0 & 100.00 & 1 & $4.68 \mathrm{E}-04$ & $4.68 \mathrm{E}-04$ & $\mathrm{D}$ & 2.65 \\
\hline NNW & 100 & 0 & 100.00 & 1 & $6.48 \mathrm{E}-04$ & $6.48 \mathrm{E}-04$ & $\mathrm{E}$ & 2.65 \\
\hline $\mathrm{N}$ & 100 & 0 & 100.00 & 1 & $7.07 \mathrm{E}-04$ & $7.07 \mathrm{E}-04$ & $\mathrm{E}$ & 2.65 \\
\hline NNE & 100 & 0 & 100.00 & 1 & $6.28 \mathrm{E}-04$ & $6.28 \mathrm{E}-04$ & $\mathrm{E}$ & 2.65 \\
\hline $\mathrm{NE}$ & 100 & 0 & 100.00 & 1 & $5.32 \mathrm{E}-04$ & $5.32 \mathrm{E}-04$ & $\mathrm{D}$ & 4.70 \\
\hline ENE & 100 & 0 & 100.00 & 1 & $5.21 \mathrm{E}-04$ & $5.21 \mathrm{E}-04$ & $\mathrm{D}$ & 4.70 \\
\hline
\end{tabular}




\section{RPP-5924 REV 0}

$\begin{array}{lrrr}\text { E } & 100 & 0 & 100.00 \\ \text { ESE } & 100 & 0 & 100.00 \\ \text { SE } & 100 & 0 & 100.00 \\ \text { SSE } & 100 & 0 & 100.00 \\ \text { S } & 15360 & 0 & 100.00 \\ \text { SSW } & 15360 & 0 & 100.00 \\ \text { SW } & 13200 & 0 & 100.00 \\ \text { WSW } & 11100 & 0 & 100.00 \\ \text { W } & 11100 & 0 & 100.00 \\ \text { WNW } & 11100 & 0 & 100.00 \\ \text { NW } & 10800 & 0 & 100.00 \\ \text { NNW } & 8690 & 0 & 100.00 \\ \text { N } & 8690 & 0 & 100.00 \\ \text { NNE } & 8970 & 0 & 100.00 \\ \text { NE } & 10430 & 0 & 100.00 \\ \text { ENE } & 10530 & 0 & 100.00 \\ \text { E } & 11160 & 0 & 100.00 \\ \text { ESE } & 15190 & 0 & 100.00 \\ \text { SE } & 21050 & 0 & 100.00 \\ \text { SSE } & 15360 & 0 & 100.00\end{array}$

\begin{tabular}{|c|c|}
\hline $9.48 \mathrm{E}-04$ & $9.48 \mathrm{E}-04$ \\
\hline $7.61 \mathrm{E}-04$ & $7.61 \mathrm{E}-04$ \\
\hline $5.01 \mathrm{E}-04$ & $5.01 E-04$ \\
\hline $3.36 \mathrm{E}-04$ & $3.36 \mathrm{E}-04$ \\
\hline $7.39 \mathrm{E}-10$ & $7.39 \mathrm{E}-10$ \\
\hline $7.23 E-10$ & $7.23 \mathrm{E}-10$ \\
\hline $1.06 \mathrm{E}-09$ & $1.06 \mathrm{E}-09$ \\
\hline $1.53 \mathrm{E}-09$ & $1.53 E-09$ \\
\hline $1.87 E-09$ & $1.87 E-09$ \\
\hline $2.29 E-09$ & $2.29 \mathrm{E}-09$ \\
\hline $3.83 E-09$ & $3.83 E-09$ \\
\hline $9.40 E-09$ & $9.40 \mathrm{E}-09$ \\
\hline $1.04 E-08$ & $1.04 \mathrm{E}-08$ \\
\hline $8.42 E-09$ & $8.42 \mathrm{E}-09$ \\
\hline $4.89 E-09$ & $4.89 E-09$ \\
\hline $4.65 \mathrm{E}-09$ & $4.65 \mathrm{E}-09$ \\
\hline $8.28 E-09$ & $8.28 E-09$ \\
\hline $3.24 \mathrm{E}-09$ & $3.24 \mathrm{E}-09$ \\
\hline $9.20 E-10$ & $9.20 E-10$ \\
\hline $1.06 E-09$ & $1.06 E-09$ \\
\hline
\end{tabular}

2.65

2.65

4.70

2.65

2.65

2.65

0.89

2.65

2.65

2.65

2.65

2.65

2.65

2.65

4.70

4.70

2.65

2.65

4.70

2.65 


\section{RPP-5924 REV 0}

Current Input File Name: twrs 45 r9.IN

GXQ Version 4.0

December 19, 1994

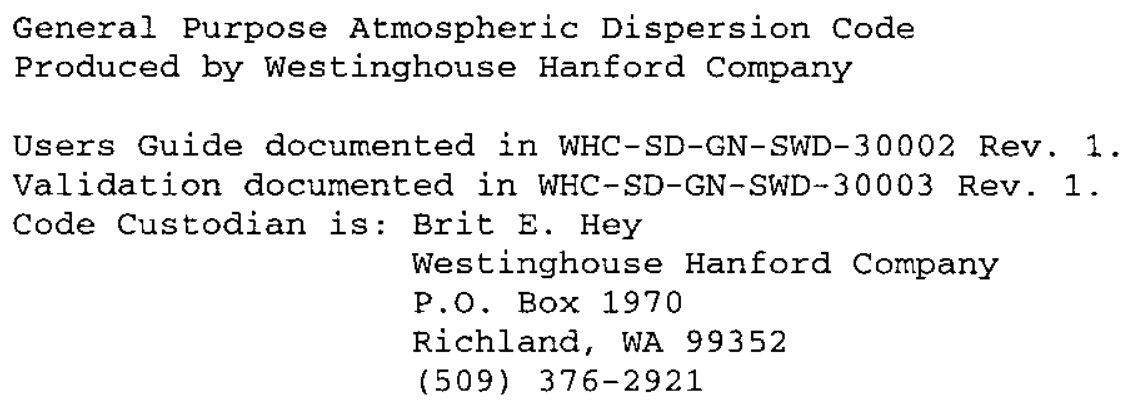




\section{RPP-5924 REV 0}

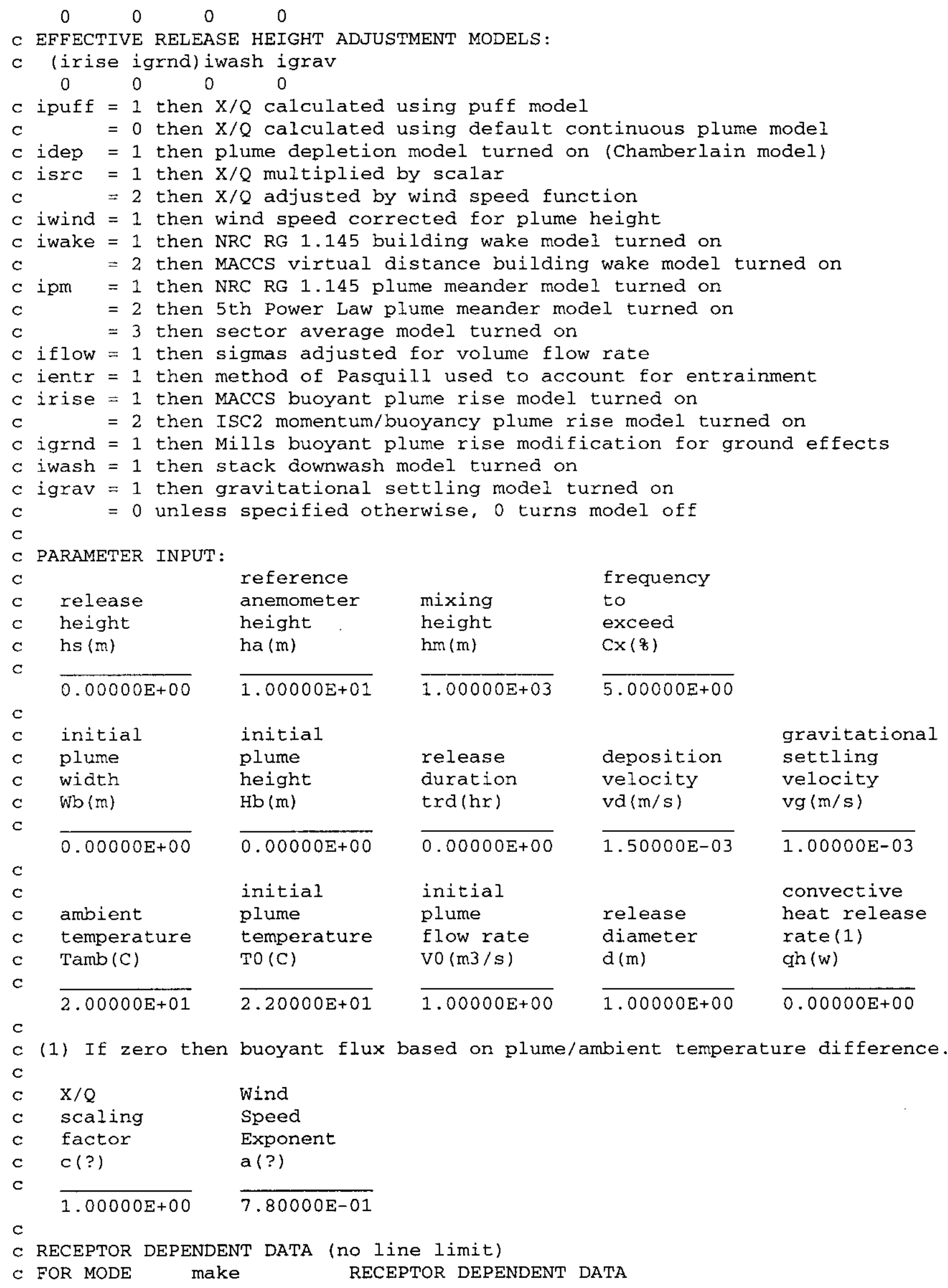




\section{RPP-5924 REV 0}

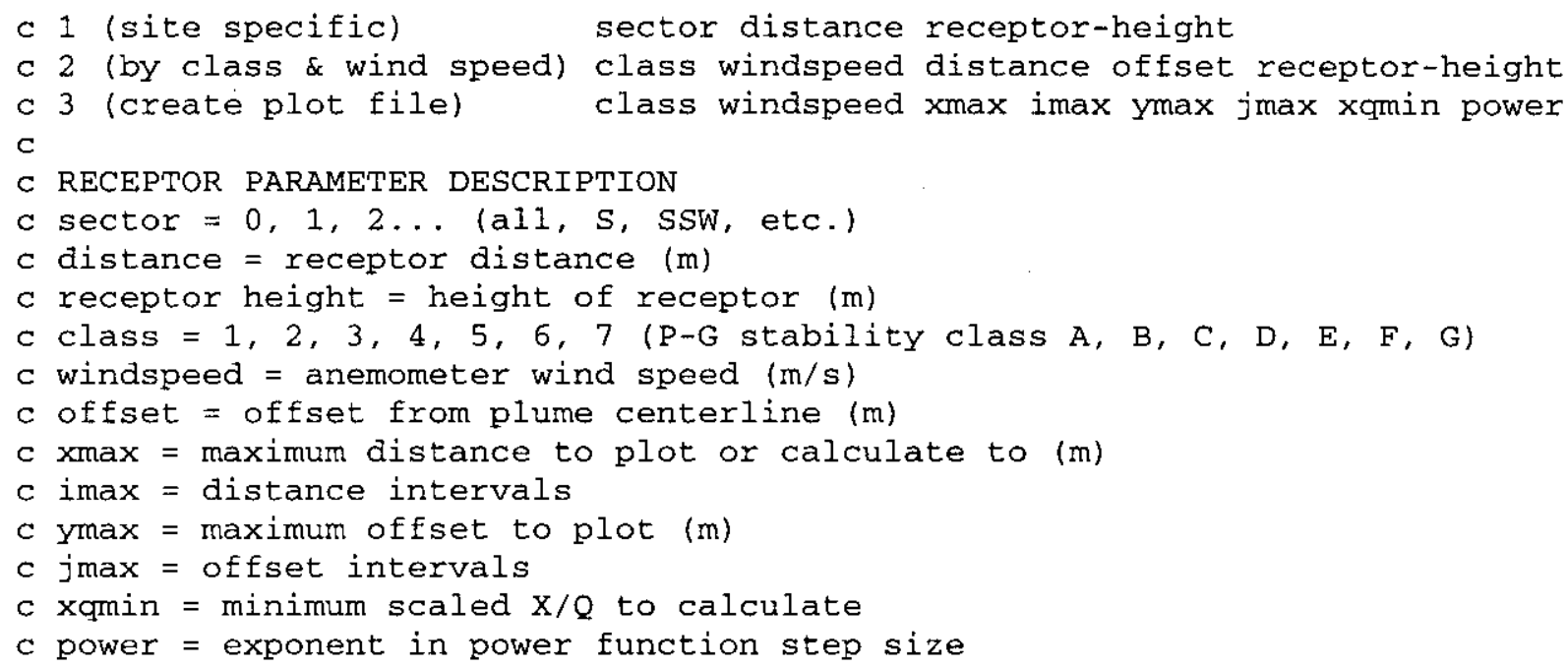

MODE :

Site specific $X / Q$ calculated.

LOGICAL CHOICES:

Joint frequency used to calculate $X / Q$ based on frequency of exceedance. No normalization of joint frequency.

$\mathrm{X} / \mathrm{Q}$ calculated for overall site.

MODELS SELECTED:

Source depletion model selected.

Default Gaussian plume model selected.

WARNING/ERROR MESSAGES:

JOINT FREQUENCY DATA:

200 AREA (HMS) - 10 M - Pasquill A - G (1983 - 1991 Average)

Created $8 / 26 / 92 \mathrm{KR}$

TWRS FSAR $95 \%$ overall river bd no BW/No PM, 45 degree sectors, $0.15 \mathrm{~cm} / \mathrm{s}$ dep

\begin{tabular}{|c|c|c|c|c|c|c|c|c|}
\hline & & & & & $\begin{array}{c}\text { TOTAL } \\
\text { POPULATION }\end{array}$ & $\begin{array}{l}\text { AVERAGE } \\
\text { INDIVIDUAL }\end{array}$ & & \\
\hline SECTOR & $\begin{array}{l}\text { DISTANCE } \\
(\mathrm{m})\end{array}$ & $\begin{array}{l}\text { RECEPT } \\
\text { HEIGHT } \\
\text { (m) }\end{array}$ & $\begin{array}{l}\text { SECT. } \\
\text { FREQ. } \\
(8)\end{array}$ & POPULATION & $\begin{array}{c}\text { SCALED } \\
\mathrm{X} / \mathrm{Q} \\
(\mathrm{s} / \mathrm{m} 3)\end{array}$ & $\begin{array}{c}\text { SCALED } \\
\mathrm{X} / \mathrm{Q} \\
(\mathrm{s} / \mathrm{m} 3)\end{array}$ & $\begin{array}{l}\text { ATM. } \\
\text { STAB. } \\
\text { CLASS }\end{array}$ & $\begin{array}{l}\text { WIND } \\
\text { SPEED } \\
\text { (m/s) }\end{array}$ \\
\hline & & & & & 2 & & $\mathrm{~F}$ & \\
\hline & 15360 & 0 & 99.94 & 1 & $14 \mathrm{E}-05$ & $14 E-05$ & & \\
\hline
\end{tabular}




\section{RPP-5924 REV 0}

Current Input File Name: twrs $45 \times 10$. IN

GXQ Version 4.0

December 19, 1994

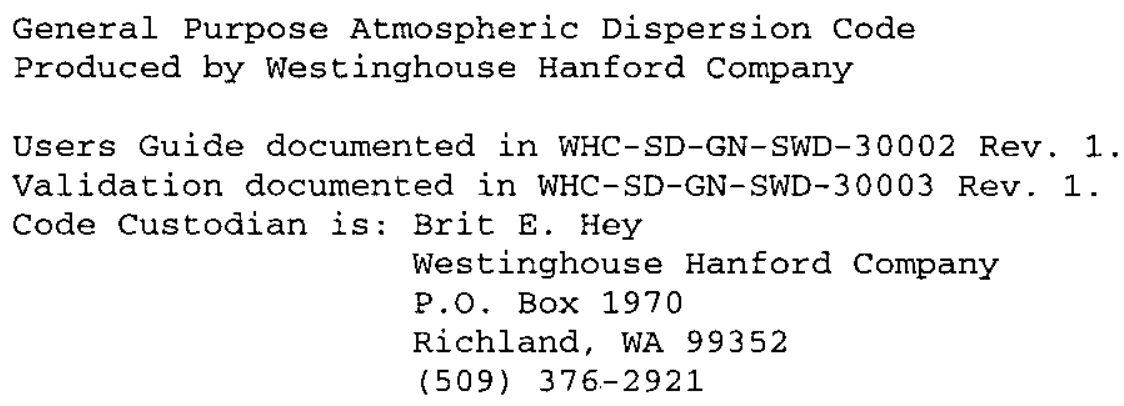




\section{RPP-5924 REV 0}

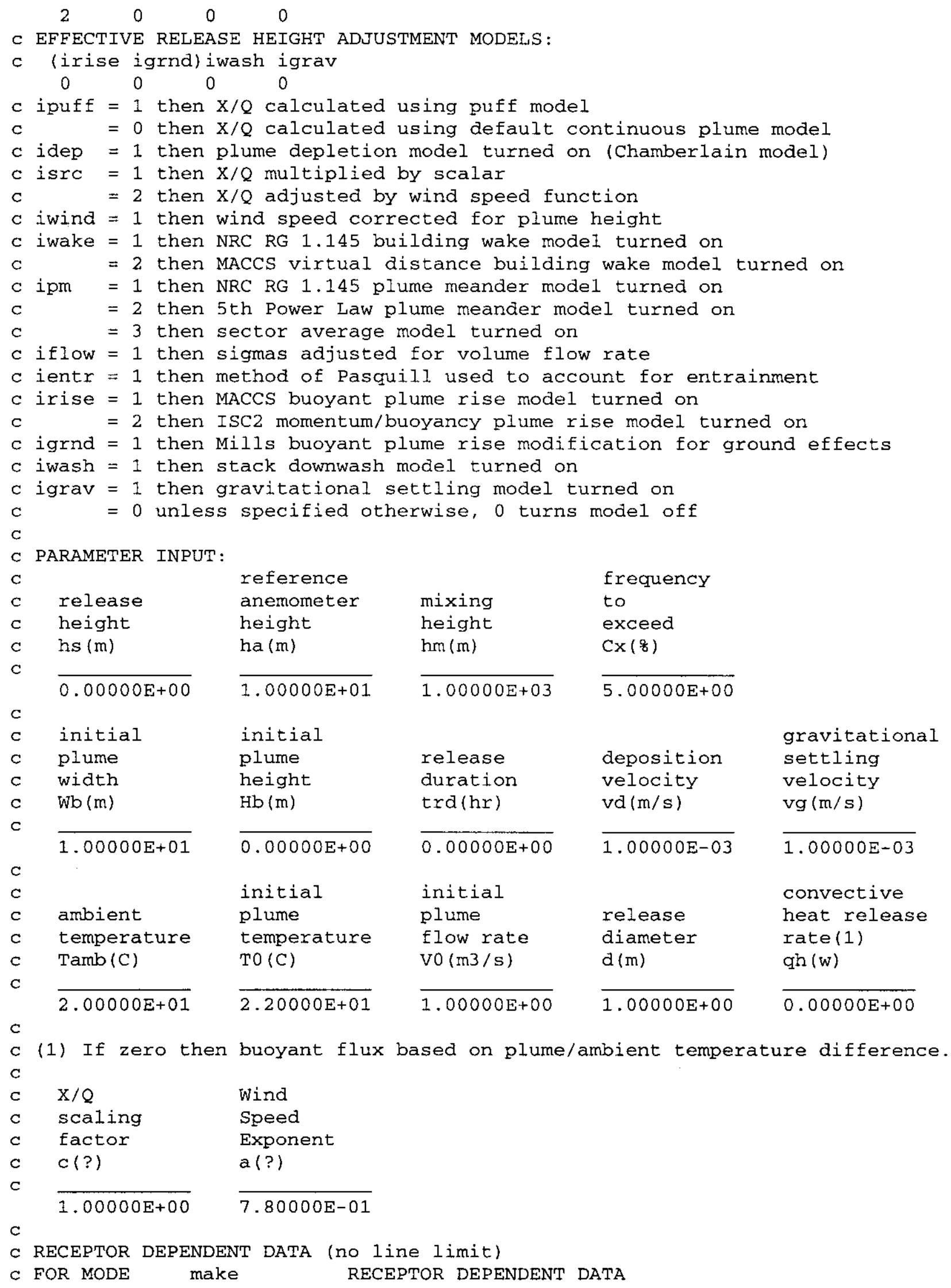




\section{RPP-5924 REV 0}

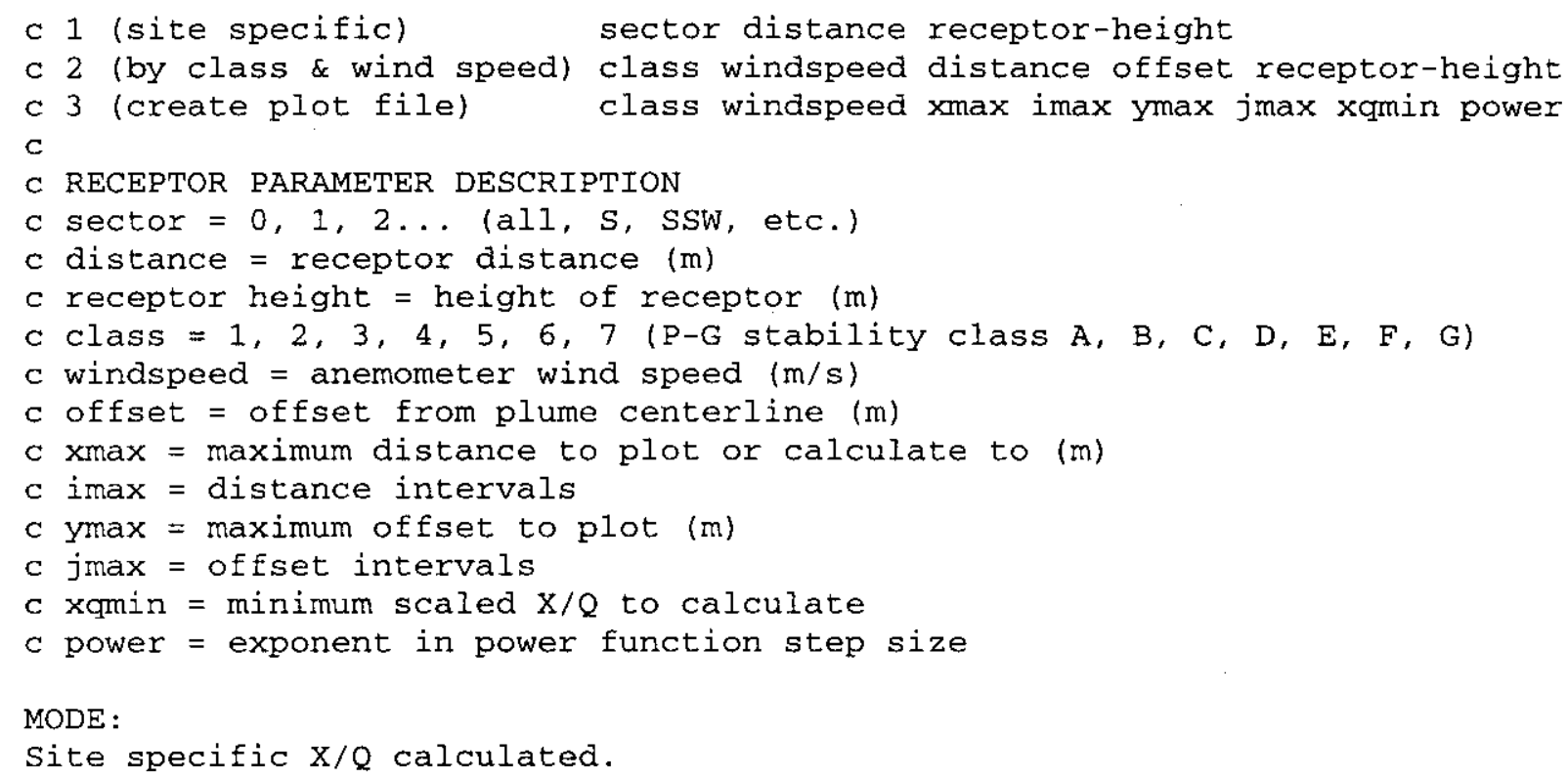

LOGICAL CHOICES:

Joint frequency used to calculate $X / Q$ based on frequency of exceedance. No normalization of joint frequency.

$\mathrm{X} / \mathrm{Q}$ calculated for overall site.

MODELS SELECTED:

MACCS Virtual source building wake model selected.

Default Gaussian plume model selected.

WARNING/ERROR MESSAGES :

JOINT FREQUENCY DATA:

200 AREA (HMS) - 10 M - Pasquill A - G (1983 - 1991 Average)

Created $8 / 26 / 92 \mathrm{KR}$

TWRS FSAR 95\% overall river bd no BW/No PM, 45 degree sectors, $10 \mathrm{~m}$ wide source

\begin{tabular}{|c|c|c|c|c|c|c|c|c|}
\hline & & & & & $\begin{array}{c}\text { TOTAL } \\
\text { POPULATION }\end{array}$ & $\begin{array}{l}\text { AVERAGE } \\
\text { INDIVIDUAL }\end{array}$ & & \\
\hline & & RECEPT & SECT. & & SCALED & SCALED & ATM. & WIND \\
\hline SECTOR & $\begin{array}{l}\text { DISTANCE } \\
\text { (m) }\end{array}$ & $\begin{array}{l}\text { HEIGHT } \\
\text { (m) }\end{array}$ & $\begin{array}{l}\text { FREQ. } \\
(\xi)\end{array}$ & POPULATION & $\begin{array}{l}X / Q \\
(s / m 3)\end{array}$ & $\begin{array}{l}X / Q \\
(s / m 3)\end{array}$ & $\begin{array}{l}\text { STAB. } \\
\text { CLASS }\end{array}$ & $\begin{array}{l}\text { SPEED } \\
(\mathrm{m} / \mathrm{s})\end{array}$ \\
\hline & 100 & 0 & 99.94 & 1 & $2.24 \mathrm{E}-02$ & $2.24 \mathrm{E}-02$ & F & 0.89 \\
\hline ALL & 15360 & 0 & 99.94 & 1 & $2.21 \mathrm{E}-05$ & $2.21 \mathrm{E}-05$ & $\mathrm{~F}$ & 0.89 \\
\hline
\end{tabular}




\section{RPP-5924 REV 0}

Current Input File Name: twrs $45 \times 11$. IN

GXQ Version 4.0

December 19,1994

General Purpose Atmospheric Dispersion Code

Produced by Westinghouse Hanford Company

Users Guide documented in WHC-SD-GN-SWD-30002 Rev. 1.

Validation documented in WHC-SD-GN-SWD-30003 Rev. 1.

Code Custodian is: Brit E. Hey

Westinghouse Hanford Company

P.O. Box 1970

Richland, WA 99352

(509) 376-2921

Run Date $=03 / 16 / 00$

Run Time $=09: 46: 48.99$

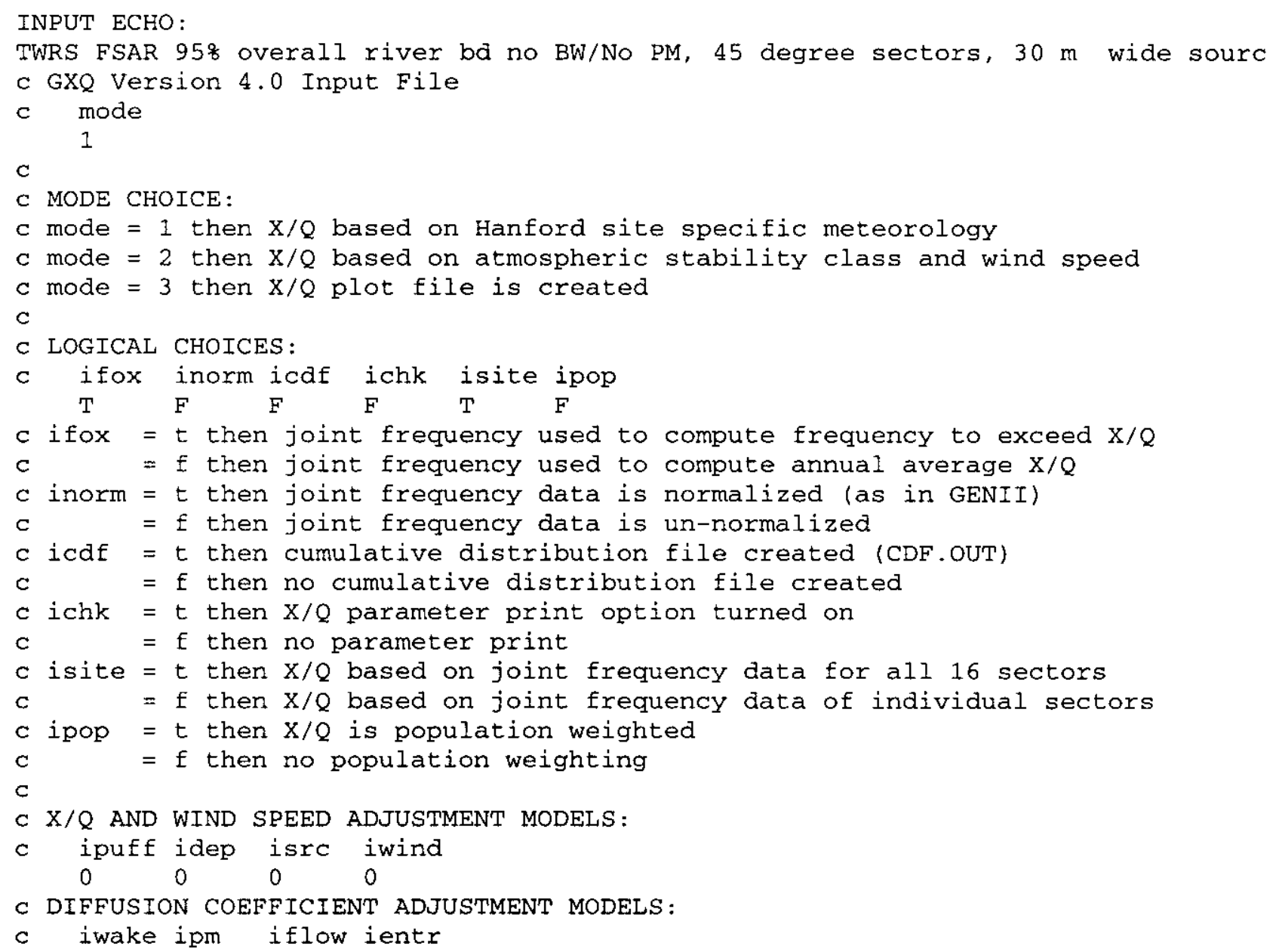




\section{RPP-5924 REV 0}

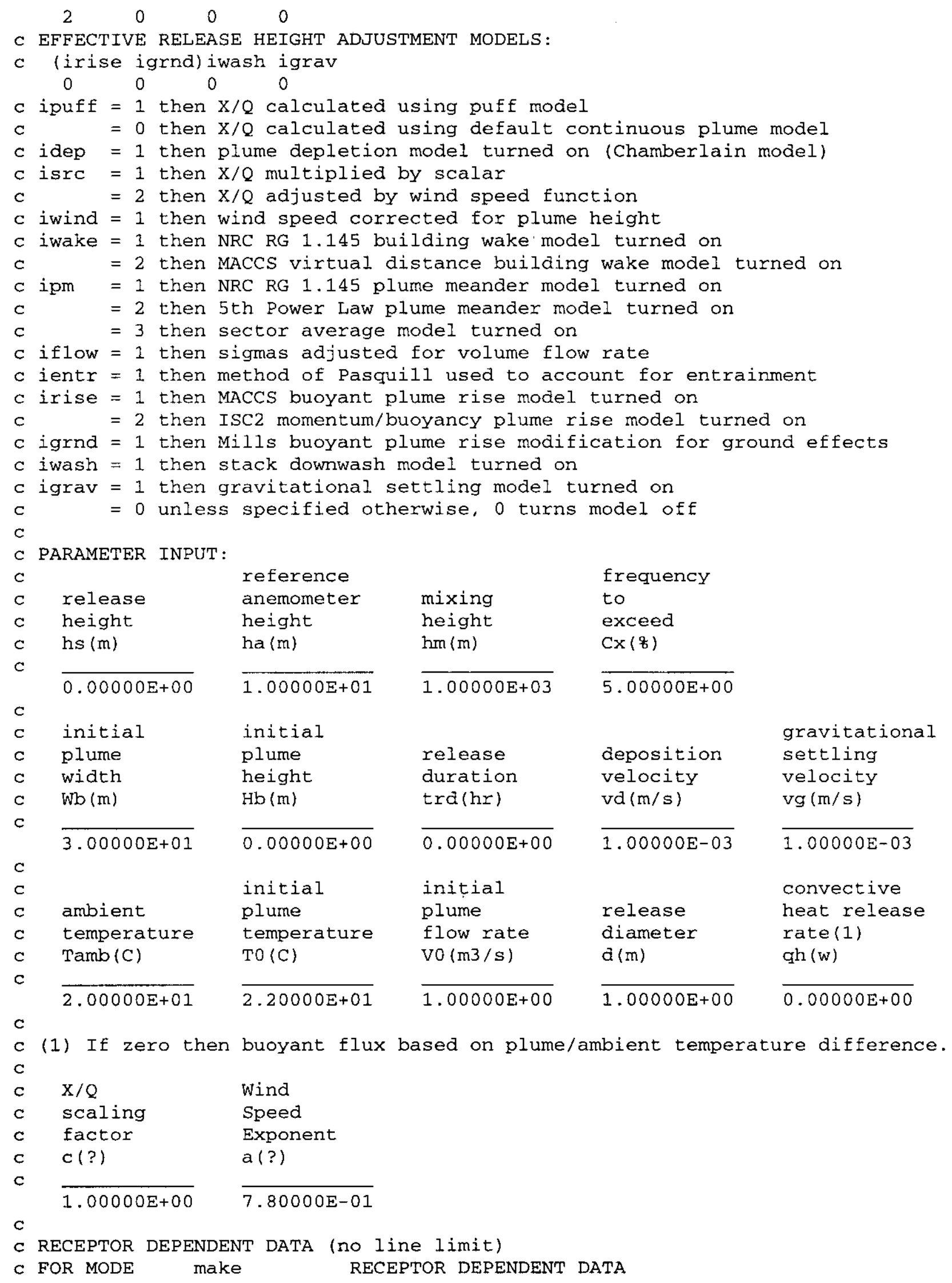




\section{RPP-5924 REV 0}

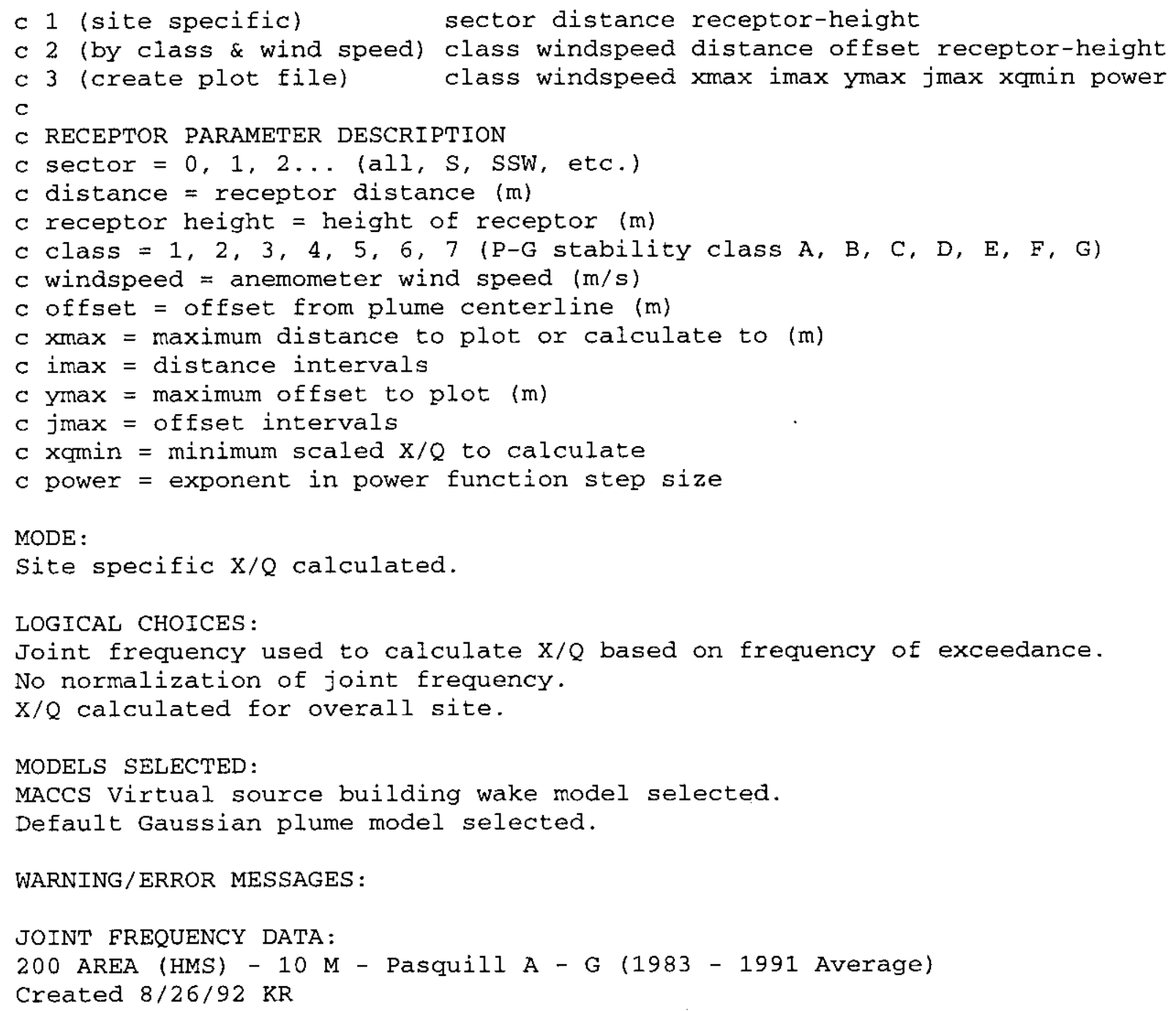

TWRS FSAR $95 \%$ overall river bd no BW/No PM, 45 degree sectors, $30 \mathrm{~m}$ wide source

\begin{tabular}{|c|c|c|c|c|c|c|c|c|}
\hline \multirow[b]{3}{*}{ SECTOR } & & & & & $\begin{array}{c}\text { TOTAL } \\
\text { POPULATION }\end{array}$ & $\begin{array}{l}\text { AVERAGE } \\
\text { INDIVIDUAL }\end{array}$ & & \\
\hline & & RECEPT & SECT. & & SCALED & SCALED & ATM & WIND \\
\hline & $\begin{array}{l}\text { DISTANCE } \\
\text { (m) }\end{array}$ & $\begin{array}{l}\text { HEIGHT } \\
\text { (m) }\end{array}$ & $\begin{array}{c}F R E Q . \\
(q)\end{array}$ & POPULATION & $\begin{array}{l}X / Q \\
(s / m 3)\end{array}$ & $\begin{array}{l}X / Q \\
(\mathrm{~s} / \mathrm{m} 3)\end{array}$ & $\begin{array}{l}\text { STAB. } \\
\text { CLASS }\end{array}$ & $\begin{array}{l}\text { SPEED } \\
(\mathrm{m} / \mathrm{s})\end{array}$ \\
\hline ALL & 100 & 0 & 99.94 & 1 & 1. $31 \mathrm{E}-02$ & $1.31 E-02$ & $\mathrm{~F}$ & 0.89 \\
\hline ALL & 15360 & 0 & 99.94 & 1 & $2.19 \mathrm{E}-05$ & $2.19 E-05$ & $F$ & 0.89 \\
\hline
\end{tabular}




\section{RPP-5924 REV 0}

\section{APPENDIX B}

\section{CALCULATIONS TO SUPPORT THE SOURCE TERM}

USED IN THE RIVER PROCTECTION PROJECT

FINAL SAFETY ANALYSIS REPORT 
RPP-5924 REV 0

This page intentionally blank.

B-2 
RPP-5924 REV 0

APPENDIX B

\section{CALCULATIONS TO SUPPORT THE SOURCE TERM USED IN THE RIVER PROCTECTION PROJECT FINAL SAFETY ANALYSIS REPORT}

\section{B1.0 INTRODUCTION}

The following analyses are documented in this appendix:

- The impact of using dose conversion factors (DCFs) from ICRP-68, Dose Coefficients for Intakes of Radionuclides by Workers--Replacement of ICRP Publication 61, and from ICRP-71, Age Dependent Doses to Members of the Public from Intake of Radionuclides Part 4 Inhalation Dose Coefficients, rather than DCFs from the more traditional ICRP-26, Recommendations of the International Commission on Radiological Protection, and ICRP-30, Limits for Intakes of Radionuclides by Workers (Section B2.0)

- An average DCF for the alpha-emitters derived for use with the total alpha concentration (Section B3.0)

- A method of including the dose from ingestion, resuspension, and ground shine for the offsite dose for the first 24 hours after the accident (Section B4.0)

- Additional calculations to confirm that the isotopes used for the dose calculation are adequate to encompass all other isotopes based on predictions of the fission product inventory in the tanks (Section B5.0).

These calculations are discussed in the following sections.

\section{B2.0 DOSE CONVERSION FACTORS}

The unit liter dose (ULD) calculations for the River Protection Project (RPP) Final Safety Analysis Report (FSAR), documented in HNF-SD-WM-SAR-067, Tank Waste Remediation System Final Safety Analysis Report, relied on information documented in WHC-SD-WM-SARR-016, Tank Waste Compositions and Atmospheric Dispersion Coefficients for Use in Safety Analysis Consequence Assessments. WHC-SD-WM-SARR-016 used DCFs from ICRP-26 and ICRP-30, which were issued in 1977 and 1979 by the International Commission on Radiological Protection (ICRP). The ICRP modified its internal dose conversion model in 1990, which resulted in the generation of different DCFs. ICRP-68 gives updated 
DCFs for workers and ICRP-71 and ICRP-72, Age Dependent Doses to Members of the Public from Intake of Radionuclides Part 5 compilation of Ingestion and Inhalation Dose Coefficients, give updated DCFs for the public (offsite receptor). Section B2.1 documents a calculation of the doses to the onsite worker using updated methodology as given in ICRP-61, Annual Limits on Intake of Radionuclides by Workers Based on the 1990 Recommendations, and ICRP- 68. Section B2.3 discusses evaluation of the doses to the offsite receptor using updated methodology from ICRP-71. Section B2.4 presents updated data on breathing rates.

The principal differences in the updated ICRP methods are a revised lung model and refined weighting factors for several organs. These revised DCFs are documented in ICRP-61; corrected factors for the onsite worker are given in ICRP-68, and the corrected factors for the public are given in ICRP-71 and ICRP-72.

\section{B2.1 ONSITE DOSE CONVERSION FACTORS BASED ON METHODOLOGY FROM ICRP-61 AND ICRP-68}

DCFs are given for up to three lung clearance classes for each isotope. ICRP-61 and ICRP-68 use the notation $\mathrm{F}, \mathrm{M}$, and $\mathrm{S}$ (fast, moderate, and slow) for clearance class rather than the $\mathrm{D}, \mathrm{W}$, and Y (daily, weekly, and yearly) that are used by ICRP-26. The clearance class depends on the chemical compound of the isotope and how the human body processes the compound. The clearance class that produces the largest doses is used in this report for each isotope except for

${ }^{90} \mathrm{Sr}$. Class "D" was used in the RPP FSAR (HNF-SD-WM-SAR-067) for ${ }^{90} \mathrm{Sr}$ rather than the larger "Y" factor because the only strontium compound that is in the " $\mathrm{Y}$ " class is $\mathrm{SrTiO}_{3}$, which is not expected to be found in the Hanford Site waste. The "F" clearance factor was therefore used for ${ }^{90} \mathrm{Sr}$ rather than the larger "S" factor for the calculation with the ICRP-61 and ICRP-68 DCFs. The DCFs are shown in Table B2-1 for both the ICRP-26 and the ICRP-61 and ICRP-68 models.

The ICRP-68 inhalation DCFs are given for both a $1-\mu \mathrm{m}$ and $5-\mu \mathrm{m}$ activity median aerodynamic diameter (AMAD) particle size. Both sets of factors are given in Table B2-1. The 5- $\mu$ m AMAD are smaller for the transuranic isotopes and result in lower ULDs for the RPP isotope mixes. ICRP-68 states in Section 2.1: "For occupational exposure the default value now recommended for the Activity Median Aerodynamic Diameter (AMAD) is $5 \mu \mathrm{m}$ (ICRP-66, Paragraph 181), which is considered to be more representative of workplace aerosols than the $1 \mu \mathrm{m}$ value adopted in ICRP Publication 30." The Safety Evaluation Report (TWRS-RT-SER-003) of the FSAR (HNF-SD-WM-SAR-067) also recommends the use of 5- $\mu$ m data. DOE-HDBK-3010-94, Airborne Release Fractions/Rates and Respirable Fractions for Nonreactor Nuclear Facilities, considers particles less than $10 \mu \mathrm{m}$ in diameter as respirable. The use of the ICRP-68 DCFs for particles $5 \mu \mathrm{m}$ in diameter therefore appears justifiable. 
Table B2-1. Inhalation Dose Conversion Factors.

\begin{tabular}{|c|c|c|c|}
\hline Isotope & $\begin{array}{c}\text { ICRP-26a } \\
\text { DCF } \\
(\mathrm{Sv} / \mathrm{Bq})\end{array}$ & $\begin{array}{c}\text { ICRP-68 } \\
\text { DCF } \\
\text { 1- } \mu \text { m AMAD } \\
(\mathrm{Sv} / \mathrm{Bq})\end{array}$ & $\begin{array}{c}\text { ICRP-68 } \\
\text { DCF } \\
\text { 5- } \mu \text { m AMAD } \\
(\mathrm{Sv} / \mathrm{Bq})\end{array}$ \\
\hline${ }^{60} \mathrm{Co}$ & 5.91 E-08 & $2.9 \mathrm{E}-08$ & $1.7 \mathrm{E}-08$ \\
\hline${ }^{90} \mathrm{Sr}$ & $6.47 \mathrm{E}-08$ & $2.4 \mathrm{E}-08$ & $3.0 \mathrm{E}-08$ \\
\hline${ }^{90} \mathrm{Y}$ & $2.28 \mathrm{E}-09$ & $1.5 \mathrm{E}-09$ & $1.7 \mathrm{E}-09$ \\
\hline${ }^{1.37} \mathrm{Cs}$ & $8.63 \mathrm{E}-09$ & $4.8 \mathrm{E}-09$ & $6.7 \mathrm{E}-09$ \\
\hline${ }^{154} \mathrm{Eu}$ & $7.73 \mathrm{E}-08$ & $5.0 \mathrm{E}-08$ & $3.5 \mathrm{E}-(08$ \\
\hline${ }^{237} \mathrm{~Np}$ & $1.46 \mathrm{E}-04$ & $2.1 \mathrm{E}-05$ & $1.5 \mathrm{E}-05$ \\
\hline${ }^{238} \mathrm{Pu}$ & $1.06 \mathrm{E}-04$ & $4.3 \mathrm{E}-05$ & $3.0 \mathrm{E}-05$ \\
\hline${ }^{234} \mathrm{Pu}$ & $1.16 \mathrm{E}-04$ & $4.7 \mathrm{E}-05$ & $3.2 \mathrm{E}-05$ \\
\hline${ }^{241} \mathrm{Pu}$ & $2.23 \mathrm{E}-066$ & $8.5 \mathrm{E}-(07$ & $5.8 \mathrm{E}-07$ \\
\hline${ }^{24 !} \wedge \mathrm{m}$ & $1.20 \mathrm{E}-04$ & 3.9 E-05 & $2.7 \mathrm{E}-05$ \\
\hline${ }^{244} \mathrm{Cm}$ & $6.70 \mathrm{E}-05$ & $2.5 \mathrm{E}-05$ & $1.7 \mathrm{E}-05$ \\
\hline
\end{tabular}

"ICRP-26, 1977. Recommondations of the Lmernational Commission on Radiological Protection, Annals of the International Commission on Radiation Protection, Volume I, Number 3, lisevier Science, Tarrytown. New York.

"ICRP-68, 1994, Dose Coefficients for Intake's of Rodionuclides by Workers-Replacement of ICRP Publication 61. Annals of the International Commission on Radiological Prolection, Volume 24, Number 4. Elsevier Science, Tarrylown. New York.

$\triangle \mathrm{MAD}=$ activity median ancodynamic diameter.

$D C F=$ dose conversion faclor.

ICRP-71 and ICRP-72 give age-dependent doses for members of the public. ICRP-71 discusses the methods, and ICRP-72 gives a summary of the DCFs. There are several differences between the ICRP 68 and the ICRP-71 data. The following is a summary of the differences.

- DCFs in ICRP-71 are given for different ages: 3 months, 1 year, 5 years, 10 years, 15 years, and adult. In general, DCFs for infants are about a factor of two higher than for adults, and intermediate ages show intermediate DCFs. The data in ICRP-71 indicate that the breathing rate in cubic meters per second is lower for the younger ages. Since dose is a function of both DCF and breathing rate, using the adult factors is reasonable. The doses for different ages are compared in Table B2-2. The product of breathing rate and DCF is highest for the adult for the dominant isotopes.

- DCFs are given only for $1-\mu \mathrm{m}$ AMAD in ICRP-71 and ICRP-72 (i.e., no 5- $\mu \mathrm{m}$ data are given). ICRP-71 indicates in Section 2.3: "For environmental exposure, the default Activity Median Acrodynamic Diameter (AMAD) is taken to be $1 \mu \mathrm{m}$." 
- ICRP-68 presents data for two clearance classes, $M$ and $S$, for transuranic isotopes. ICRP-71 give data for three clearance classes, $\mathrm{F}, \mathrm{M}$, and $\mathrm{S}$, for the transuranic isotopes. The DCFs in class $F$ are the largest. However, the statement is made for americium, neptunium, plutonium and curium in ICRP-71: "Default Type $M$ is recommended for use in the absence of specific information." Class $M$ data are used in Table B2-2.

Table B2-2. Comparison of Dose Conversion Factor Times Breathing Rates for Receptors of Various Ages.

\begin{tabular}{|c|c|c|c|c|c|c|}
\hline Age & 3 months & 1 year & 5 years & 10 years & 15 years & Adult \\
\hline $\begin{array}{l}\text { Air breathed in } 24 \text { hours } \\
\left(\mathrm{m}^{3}\right)^{*}\end{array}$ & 2.86 & 5.16 & 8.72 & 15.3 & 20.1 & 22.2 \\
\hline $\begin{array}{l}\text { Average breathing rate } \\
\left(\mathrm{m}^{3 / \mathrm{s})}\right.\end{array}$ & $3.3 \mathrm{E}-05$ & $6.0 \mathrm{E}-05$ & $1.0 \mathrm{E}-04$ & $1.8 \mathrm{E}-04$ & $2.3 \mathrm{E}-04$ & $2.6 \mathrm{E}-04$ \\
\hline${ }^{* 1} \mathrm{Sr} \mathrm{DCF}(\mathrm{Sv} / \mathrm{Bq})$ & $1.5 \mathrm{E}-07$ & $1.1 \mathrm{E}-07$ & $6.5 \mathrm{~F}-08$ & $5.1 \mathrm{E}: 08$ & $5.0 \mathrm{E}:-08$ & $3.6 \mathrm{E}-08$ \\
\hline $\begin{array}{l}{ }^{21} \mathrm{Sr} \mathrm{DCF} \text { times breathing } \\
\text { rate }\left(\mathrm{Sv}-\mathrm{m}^{3} / \mathrm{Bq}-\mathrm{s}\right)\end{array}$ & $5.0 \mathrm{E}-12$ & $6.6 \mathrm{E}-12$ & $6.6 \mathrm{E}-12$ & $9.0 \mathrm{E}-12$ & $1.16 \mathrm{E}-11$ & $9.3 \mathrm{~L}-12$ \\
\hline${ }^{\text {(Y) }} \mathrm{YDCI}(\mathrm{Sv} / \mathrm{Bq})$ & $1.3 \mathrm{E}-08$ & $8.8 \mathrm{E}-09$ & $4.2 \mathrm{E}-09$ & 2.7 E-09 & $1.8 \mathrm{E}-09$ & $1.5 \mathrm{l}:-09$ \\
\hline $\begin{array}{l}{ }^{31} \mathrm{Y} \text { DCF times breathing } \\
\text { rate }\left(\mathrm{Sv}-\mathrm{m}^{3} / \mathrm{Bq}-\mathrm{s}\right)\end{array}$ & $4.3 \mathrm{E}-13$ & $5.3 \mathrm{E}-13$ & $4.2 \mathrm{E}-13$ & $4.8 \mathrm{E}-13$ & $4.2 \mathrm{E}-13$ & $3.9 \mathrm{E}-1.3$ \\
\hline${ }^{1.37} \mathrm{Cs} \mathrm{DCF}(\mathrm{Sv} / \mathrm{Bq})$ & $8.8 \mathrm{E}-09$ & $5.4 \mathrm{E}-09$ & $3.6 \mathrm{E}-09$ & $3.7 \mathrm{E}-(09$ & $4.4 \mathrm{E}-09$ & $4.6 \mathrm{E}-09$ \\
\hline $\begin{array}{l}\left.{ }^{137} \mathrm{Cs} \mathrm{I}\right)(\mathrm{I} \text { times } \\
\text { breathing rate } \\
\left(\mathrm{Sv}-\mathrm{m}^{3} / \mathrm{Bq}-\mathrm{s}\right)\end{array}$ & $2.9 \mathrm{E}-13$ & $3.2 \mathrm{~F}-13$ & $3.6 \mathrm{E}-13$ & $6.6 \mathrm{E}-13$ & $1.0 \mathrm{E}-12$ & $1.2 \mathrm{E}-12$ \\
\hline${ }^{23 \mathrm{Pu}} \mathrm{DCF}(\mathrm{Sv} / \mathrm{Bq})$ & $7.8 \mathrm{E}-05$ & $7.4 \mathrm{E}-05$ & $5.6 \mathrm{E}-05$ & $4.4 \mathrm{E}-0.5$ & $4.3 \mathrm{E}-05$ & $4.6 \mathrm{E}_{-}(05$ \\
\hline $\begin{array}{l}{ }^{2.3 \gamma} \mathrm{Pu} \mathrm{DCF} \text { times } \\
\text { breathing rate } \\
\left(\mathrm{Sv}-\mathrm{m}^{3} / \mathrm{Bq}_{-} \mathrm{s}\right)\end{array}$ & $2.6 \mathrm{E}-09$ & 4.4 J:-09 & $5.7 \mathrm{H}-09$ & $7.8 \mathrm{E}-09$ & $1.0 \mathrm{E}-08$ & $1.2 \mathrm{E}-08$ \\
\hline${ }^{234} \mathrm{Pu} \mathrm{DCF}(\mathrm{Sv} / \mathrm{Bq})$ & $8.0 \mathrm{E}-05$ & $7.7 \mathrm{E}-05$ & $6.0 \mathrm{E}-05$ & $4.8 \mathrm{E}-05$ & $4.7 \mathrm{E}-0.5$ & $5.0 \mathrm{E}-05$ \\
\hline $\begin{array}{l}{ }^{374} \mathrm{Pu} \mathrm{DCF} \text { times } \\
\text { breathing rate } \\
\left(\mathrm{Sv}-\mathrm{m}^{3} / \mathrm{Bq}-\mathrm{s}\right)\end{array}$ & $2.7 \mathrm{E}-09$ & $4.6 \mathrm{E}-09$ & $6.1 \mathrm{E}-09$ & $8.5 \mathrm{E}-09$ & $1.1 \mathrm{E}-08$ & $1.3 \mathrm{E}-08$ \\
\hline${ }^{2+1} \mathrm{Am} \mathrm{DCF}(\mathrm{Sv} / \mathrm{Bq})$ & $7.3 \mathrm{E}-05$ & $6.9 \mathrm{E}-05$ & $5.1 \mathrm{E}-05$ & 4.0 E-05 & $4.0 \mathrm{E}-05$ & $4.2 E-05$ \\
\hline $\begin{array}{l}{ }^{2+1} \wedge \mathrm{m} \text { DCF times } \\
\text { breathing rate } \\
\left(\mathrm{Sv}-\mathrm{m}^{3} / \mathrm{Bu}-\mathrm{s}\right)\end{array}$ & $2.4 \mathrm{E}-09$ & $4.1 \mathrm{E}-09$ & $5.2 \mathrm{E}-09$ & 7.1 E-09 & 9.3 E-09 & $1.1 \mathrm{E}-08$ \\
\hline
\end{tabular}

Notes: DCFs for all isotopes except ${ }^{10} \mathrm{Y}$ are from ICRP-71, 1995, Age Dependent Doses to Members of the Public from Intake of Radionuclides Part 4 Inhalation Dose Coefficiens, Annals of the International commission on Radiation Protection, Volume 25, Number 3-4, Elsevier Science, Tarrytown, New York. DCFs for "Y $Y$ are from ICRP-72, 1996, Age Dependent Doses to Members of the Public from Intake of Radionuclides Part 5 Compilation of Ingestion and Inhalation Dose Coefficients, Annals of the International Commission on Radiation Protection, Volume 26, Number 1, Elsevier Science, Tarrylown, New York.

*Breathing rate for different ages from lable 6 of ICRP-7I.

DCF - dose conversion factor. 


\section{RPP-5924 REV 0}

- ICRP-68 presents data for two clearance classes, $\mathrm{F}$ and $\mathrm{S}$, for ${ }^{90} \mathrm{Sr}$. The $\mathrm{S}$ class DCF is larger. The class F DCF is used because only one strontium compound has $\mathrm{S}$ characteristics $\left(\mathrm{SrTiO}_{2}\right)$ and that compound is not expected to be found in Hanford Site waste. ICRP-72 gives data for three clearance classes: F, M and S. ICRP-71 recommends the use of the $M$ class unless specific data are known. The $M$ class data from ICRP-71 were used in Table B2-2. Thus, the ${ }^{90} \mathrm{Sr}$ calculations for onsite workers and offsite public are based on different clearance classes.

- The F clearance class is recommended in ICRP-71 for ${ }^{137} \mathrm{Cs}$. F data are used for this isotope.

- Data for ${ }^{90} \mathrm{Y}$ and ${ }^{154} \mathrm{Eu}$ are not included in ICRP-71. Maximum DCFs were taken from ICRP-72 for ${ }^{90} \mathrm{Y}$ and ${ }^{154} \mathrm{Eu}$.

The first bullet above indicates that the doses to the adult are larger than the doses to children. This conclusion is supported by the following calculation for doses due to inhalation of a given isotope:

$$
\mathrm{D}=(\mathrm{Q})\left(\mathrm{X} / \mathrm{Q}^{\prime}\right)(\mathrm{BR})(\mathrm{DCF})
$$

where

$$
\begin{aligned}
& \mathrm{D}=\text { dose to the receptor } \\
& \mathrm{Q}=\text { amount of a given isotope released } \\
& \mathrm{X} / \mathrm{Q}^{\prime}=\text { the atmospheric dispersion coefficient } \\
& \mathrm{BR}=\text { breathing rate } \\
& \mathrm{DCF}=\text { dose conversion factor for the isotope. }
\end{aligned}
$$

The doses are proportional to the breathing rate times the DCF. The product of the average breathing rate and the DCF is given in Table B2-2 for receptors of various ages for the isotopes that are significant contributors to the inhalation dose. The dose to adults is the largest with two exceptions:

1. The dose to the 15-year old is about 25 percent higher than the dose to the adult for ${ }^{90} \mathrm{Sr}$

2. The doses for ${ }^{90} \mathrm{Y}$ for all the younger ages are significantly larger than the doses for adults.

It can, however, be seen from examining the tables of the attachment to Letter CO-00-RPP-270, Deliverable for Contract 4976, Release 8, Updated Dose Methods (L-03) (Brevick 2000), that ULDs are dominated by the transuranics. The adult dose is largest for the transuranics. Yttrium-90 is a relatively small contributor to the dose (about 1 percent or less). Strontium-90 can contribute up to about 48 percent of the dose for single-shell tank (SST) solids. The remainder is almost all from transuranics. The adult doses from transuranics are about 
20 percent higher than the closest dose to children. The use of the adult doses for comparison to risk guidelines is therefore reasonable.

The data in Table B2-2 indicate that the use of adult data for comparison to risk guidelines is reasonable.

The DCFs for offsite adults from ICRP-71 are given in Table B2-3. The data from ICRP-68 for 1 - $\mu \mathrm{m}$-diameter particles are also repeated in this table for comparison.

Table B2-3. Adult Dose Conversion Factors for Offsite Receptors.

\begin{tabular}{|l|c|c|}
\hline \multicolumn{1}{|c|}{ Isotope } & $\begin{array}{c}\text { ICRP-71 }{ }^{\mathbf{a}} \text { Dose } \\
\text { Conversion Factors } \\
\text { (Sv/Bq) }\end{array}$ & $\begin{array}{c}\text { ICRP-68 }{ }^{\mathbf{b}} \mathbf{1} \mu \mathrm{m} \text { Dose } \\
\text { Conversion Factors } \\
\text { (Sv/Bq) }\end{array}$ \\
\hline${ }^{60} \mathrm{Co}$ & $1.0 \mathrm{E}-08^{*}$ & $2.9 \mathrm{E}-08$ \\
\hline${ }^{60} \mathrm{Sr}$ & $3.6 \mathrm{E}-08^{*}$ & $2.4 \mathrm{E}-08$ \\
\hline${ }^{90)} \mathrm{Y}$ & $1.5 \mathrm{E}-09^{* * *}$ & $1.5 \mathrm{E}-09$ \\
\hline${ }^{137} \mathrm{Cs}$ & $4.6 \mathrm{E}-09^{* *}$ & $4.8 \mathrm{E}-09$ \\
\hline${ }^{154} \mathrm{Eu}$ & $5.3 \mathrm{E}-08^{* * *}$ & $5.0 \mathrm{E}-08$ \\
\hline${ }^{237} \mathrm{~Np}$ & $2.3 \mathrm{E}-05^{*}$ & $2.1 \mathrm{E}-05$ \\
\hline${ }^{238} \mathrm{Pu}$ & $4.6 \mathrm{E}-05^{*}$ & $4.3 \mathrm{E}-05$ \\
\hline${ }^{2319} \mathrm{Pu}$ & $5.0 \mathrm{E}-05^{*}$ & $4.7 \mathrm{E}-05$ \\
\hline${ }^{241} \mathrm{Pu}$ & $9.0 \mathrm{E}-07^{*}$ & $8.5 \mathrm{E}-07$ \\
\hline${ }^{241} \mathrm{Am}$ & $4.2 \mathrm{E}-05^{*}$ & $3.9 \mathrm{E}-05$ \\
\hline${ }^{244} \mathrm{Cm}$ & $2.7 \mathrm{E}-05^{*}$ & $2.5 \mathrm{E}-05$ \\
\hline
\end{tabular}

${ }^{a}$ ICRP 71, 1995, Age Dependent Doses to Members of the Public from Intake of Radionuclides Part 4 Inhalation Dose Cocfficients, Annals of the International Commission on Radiation Protection, Volume 25, Number 3-4, Elsevier Science, Tarrytown, New York.

"ICRP-68, 1994, Dose Coefficients for Intakes of Radionuclides by Workers--Replacement of ICRP Publication 61, Annals of the International Commission on Radiation Protection. Volume 24. Number 4. FIsevier Science, Tarrytown, New York.

*Class M data

** Class F data

*** Maximum value from ICRP-72 1996, Age Dependent Doses to Members of the Public from Intake of Radionuclides Part 5 Compilation of Ingestion and Inhalution Dose ('ocfficients, Annals of the International Commission on Radiation Protection, Volume 26, Number 1, Elsevier Science, Tarrytown, New York.

The DCFs from ICRP-71 and ICRP-72 are slightly larger for most isotopes than the DCFs from ICRP-68. The ${ }^{\%} \mathrm{Sr}$ DCF is larger because of the difference in clearance class. The remaining differences may be caused by the differences in the number of years used to compute the doses. 


\section{B2.3 BREATHING RATE}

Table 1 of ICRP-68 derives a breathing rate for light work assuming the individual spends 2.5 hours sitting with a breathing rate of $0.54 \mathrm{~m}^{3} / \mathrm{h}$ and 5.5 hours at light exercise with a breathing rate of $1.5 \mathrm{~m}^{3} / \mathrm{h}$. The total quantity breathed in 8 hours is $9.6 \mathrm{~m}^{3}$, giving an average breathing rate of $3.33 \times 10^{-4} \mathrm{~m}^{3} / \mathrm{s}$. This is the light-activity breathing rate that is used in the FSAR (HNF-SD-WM-SAR-067). While the peak breathing rate is higher, use of the lightactivity value is reasonable since it reflects an average of typical activities during a working day.

Table 6 of ICRP-71 indicates that the breathing rate for the offsite adult receptor is calculated assuming the receptor spends 6 hours sitting at a breathing rate of $0.54 \mathrm{~m}^{3} / \mathrm{h}, 9.75$ hours at light exercise at a breathing rate of $1.5 \mathrm{~m}^{3} / \mathrm{h}, 0.25$ hours at heavy exercise at breathing rate of $3.0 \mathrm{~m}^{3} / \mathrm{h}$, and 8 hours sleeping at a breathing rate of $0.45 \mathrm{~m}^{3} / \mathrm{h}$. The total air breathed in 24 hours is $22.2 \mathrm{~m}^{3}$ for an average breathing rate of $2.57 \times 10^{-4} \mathrm{~m}^{3} / \mathrm{s}$. This is an average breathing rate. Since many releases in the FSAR (HNF-SD-WM-SAR-067) are considerably shorter than 24 hours, it is conservative to use the light-activity breathing rate for short releases, but the $2.57 \times 10^{-4} \mathrm{~m}^{3} / \mathrm{s}$ should be used for releases of 24 hours or longer.

\section{B3.0 AVERAGE DOSE CONVERSION FACTORS FOR ALPHA EMITTERS}

Sample data from the tanks frequently give total alpha activity rather than activity from specific isotopes. A calculation of the effective DCFs for all the alpha-emitting isotopes was made using the DCFs from ICRP-26 (HNF-4754). This calculation has been repeated using the DCFs from ICRP-68 for the onsite worker and the DCFs from ICRP-71 for the offsite receptor. These DCFs can be used with the total alpha activity in the same way that the DCFs for specific isotopes are multiplied by the isotope activity. Effective DCFs for the alpha-emitters for each composite are calculated using the following formula:

$$
\mathrm{DCF}_{\text {eff }}=\frac{\sum\left(\mathrm{DCF}_{i}\right)\left(\mathrm{A}_{i}\right)}{\sum\left(\mathrm{A}_{i}\right)}
$$

where

$$
\begin{aligned}
& \mathrm{DCF}_{\text {eff }}=\text { effective dose conversion factor } \\
& \mathrm{DCF}_{\mathrm{i}}=\text { dose conversion factors for the } i \text { th isotope } \\
& \mathrm{A}_{\mathrm{i}}=\text { activity of the } i \text { th isotope. }
\end{aligned}
$$

The principal alpha-emitting isotopes include ${ }^{237} \mathrm{~Np},{ }^{238} \mathrm{Pu},{ }^{239} \mathrm{Pu},{ }^{241} \mathrm{Am}$, and ${ }^{244} \mathrm{Cm}$. The results are summarized in Table B3-1 and the detailed calculations are shown in Table B3-2 for the onsite worker using DCFs from ICRP-68 for both 1- $\mu \mathrm{m}$ and 5- $\mu \mathrm{m}$ AMAD and in Table B3-3 for the offsite receptor using DCFs from ICRP-71. These calculations are based on isotope concentrations given in WHC-SD-WM-SARR-016. These concentrations may vary for future 
analysis. It can be seen from Table B3-1, however, that the effective DCF is relatively insensitive to the specific isotope concentrations. The use of the average DCFs for computing doses from the total alpha is therefore reasonable.

Table B3-1. Effective Dose Conversion Factor for Alpha Emitters for Different Composites Based on Dose Conversion Factors from ICRP-68 and ICRP-71.

\begin{tabular}{|c|c|c|c|}
\hline Composite & $\begin{array}{l}\text { Effective DCF for } \\
\text { Tank Waste Alpha- } \\
\text { Emitters from } \\
\text { ICRP-68 for } 5 \text { - } \mu \mathrm{m} \\
\text { AMAD } \\
\text { (Sv/Bq) }\end{array}$ & $\begin{array}{l}\text { Effective DCF for } \\
\text { Tank Waste Alpha- } \\
\text { Emitters from } \\
\text { ICRP-68 }{ }^{\text {a }} \text { for } 1-\mu \mathrm{m} \\
\text { AMAD } \\
\text { (Sv/Bq) }\end{array}$ & 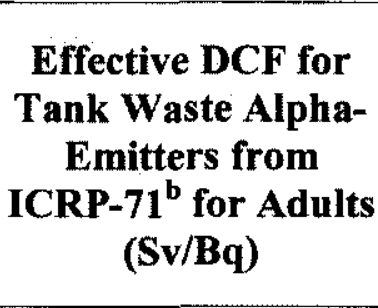 \\
\hline Single-shell tank liquids & $2.92 \mathrm{E}-(05$ & $4.26 \mathrm{E}-05$ & $4.56 \mathrm{E}-05$ \\
\hline Single-shell tank solids & $2.97 \mathrm{E}-05$ & $4.32 \mathrm{E}-05$ & $4.61 \mathrm{E}-05$ \\
\hline Double-shell tank liquids & $2.79 \mathrm{E}-05$ & $4.04 \mathrm{E}-05$ & $4.34 \mathrm{E}-05$ \\
\hline Double-shell lank solids & $2.88 \mathrm{E}-05$ & $4.19 \mathrm{E}-05$ & $4.49 \mathrm{E}-05$ \\
\hline Average & $2.90 \mathrm{E}-05$ & $4.20 \mathrm{~F}-05$ & $4.50 \mathrm{E}-05$ \\
\hline
\end{tabular}

"ICRP-68, 1994, Dose Cocfficients for Intakes of Radionuclides by Workers.-.-Replacement of ICRP

Publication 61, Annals of the International Commission on Radiation Protection, Volume 24, Number 4, Elsevier Science, Tarrytown, New York.

'IC'RP-71, 1995, Age Dependent Dose's to Members of the Public from Intake of Radionaclides Part 4 Inhalation Dose Coefficients, Annals of the International Commission on Radiation Protection, Volumi 25, Number 3-4, tilsevier Science, Tarrytown, New York.

AMAD :- activity median aerodynanic diameter.

DCF - dose conversion factor.

The ICRP-68 1- $\mu \mathrm{m}$ data are shown for information. The average DCF of $2.90 \times 10^{-5} \mathrm{~Sv} / \mathrm{Bq}$ was used for the ICRP-68 5- $\mu \mathrm{m}$ data, and the average of $4.50 \times 10^{-5} \mathrm{~Sv} / \mathrm{Bq}$ was used for lCRP-71 DCF. The concentrations were based on the worst-case-tank composite concentrations. Calculations of tank-by-tank concentrations may result in slightly different DCFs. However, it can be seen from Table B3-1 that the variations in different composites are small. Use of the average for all the tank-by-tank composites is therefore reasonable. 
Table B3-2. Calculation of Effective Dose Conversion Factor for the Onsite Worker. (2 sheets)

\begin{tabular}{|c|c|c|c|c|c|}
\hline \multirow[b]{2}{*}{ Isotope } & \multirow{2}{*}{$\begin{array}{c}\text { Activity/L } \\
\text { (Bq/L) }\end{array}$} & \multicolumn{2}{|c|}{ 5- $\mu \mathrm{m}$ AMAD } & \multicolumn{2}{|c|}{ 1- $\mu$ M AMAD } \\
\hline & & $\begin{array}{c}\mathrm{DCF} \\
(\mathrm{Sv} / \mathbf{B q})\end{array}$ & $\begin{array}{l}\text { DCF Activity } \\
(\mathrm{Sv} / \mathrm{L})\end{array}$ & $\begin{array}{c}\text { DCF } \\
(\mathrm{Sv} / \mathrm{Bq}) \\
\end{array}$ & $\begin{array}{c}\text { DCF* Activity }^{*} \text { (Sv/L) } \\
\end{array}$ \\
\hline \multicolumn{6}{|c|}{ Effective DCF for Single-Shell Tank Liquids } \\
\hline${ }^{237} \mathrm{~Np}$ & $0.00 \mathrm{E}+00$ & $1.5 \mathrm{E}-05$ & $0.00 \mathrm{E}+00$ & $2.1 \mathrm{E}-05$ & $0.00 \mathrm{E}+00$ \\
\hline${ }^{238} \mathrm{Pu}$ & $9.21 \mathrm{E}+04$ & $3.0 \mathrm{E}-05$ & $2.76 \mathrm{E}-00$ & $4.3 \mathrm{E}-05$ & $3.96 \mathrm{E}-(00$ \\
\hline${ }^{231} \mathrm{Pu}$ & $3.62 \mathrm{E}+07$ & $3.2 \mathrm{E}-05$ & $1.16 \mathrm{E}+03$ & $4.7 \mathrm{E}-05$ & $1.70 \mathrm{E}+03$ \\
\hline${ }^{241} \mathrm{Am}$ & $4.23 \mathrm{E}+07$ & $2.7 \mathrm{E}-05$ & $1.14 \mathrm{E}+03$ & 3.9E-05 & $1.65 E+03$ \\
\hline${ }^{244} \mathrm{Cm}$ & $4.23 \mathrm{E}+05$ & $1.7 E-05$ & $7.19 \mathrm{E}-(00$ & $2.5 \mathrm{E}-05$ & $1.06 \mathrm{E}+01$ \\
\hline Total & $7.90 \mathrm{E}+07$ & & $2.31 \mathrm{E}+03$ & & $3.37 \mathrm{E}+03$ \\
\hline \multicolumn{3}{|c|}{ Effective $D C F(S v / B q)$} & $2.92 \mathrm{E}-05$ & & $4.26 \mathrm{E}-05$ \\
\hline \multicolumn{6}{|c|}{ Effective DCF for Single-Shell Tank Solids } \\
\hline${ }^{237} \mathrm{~Np}$ & $3.02 \mathrm{E}+07$ & $1.5 \mathrm{E}-() 5$ & $4.53 \mathrm{E}+02$ & $2.1 \mathrm{E}-05$ & $6.34 \mathrm{E}+02$ \\
\hline${ }^{238} \mathrm{Pu}$ & $1.87 \mathrm{E}+08$ & $3.0 \mathrm{E}-05$ & $5.61 \mathrm{E}+03$ & $4.3 \mathrm{E}-05$ & $8.04 \mathrm{E}+03$ \\
\hline${ }^{23.19} \mathrm{Pu}$ & $4.40 \mathrm{E}+08$ & $3.2 \mathrm{E}-05$ & $1.41 \mathrm{E}+04$ & $4.7 \mathrm{E}-05$ & $2.07 \mathrm{E}+04$ \\
\hline${ }^{241} \mathrm{Am}$ & $2.29 \mathrm{E}+08$ & $2.7 \mathrm{E}-(05$ & $6.18 \mathrm{E}+03$ & $3.9 \mathrm{E}-05$ & $8.93 E+03$ \\
\hline${ }^{244} \mathrm{Cm}$ & $2.29 \mathrm{E}+06$ & $1.7 \mathrm{E}-05$ & $3.89 \mathrm{E}+01$ & $2.5 E-05$ & $5.73 \mathrm{E}+01$ \\
\hline Total & $8.88 \mathrm{E}+08$ & & $2.64 \mathrm{E}+04$ & & $3.83 \mathrm{E}+04$ \\
\hline \multicolumn{3}{|c|}{ Effective DCF (Sv/Bq) } & $2.97 \mathrm{E}-05$ & & $4.32 \mathrm{E}-05$ \\
\hline \multicolumn{6}{|c|}{ Effective DCF for Double-Shell Tank Liquids } \\
\hline Np-237 & $2.30 \mathrm{E}+05$ & $1.5 \mathrm{E}-05$ & $3.45 \mathrm{E}-00$ & $2.1 \mathrm{E}-05$ & $4.83 \mathrm{E}-00$ \\
\hline${ }^{238} \mathrm{Pu}$ & $1.78 \mathrm{E}+06$ & $3.0 \mathrm{E}-05$ & $5.34 \mathrm{E}+01$ & $4.3 \mathrm{E}-05$ & $7.65 \mathrm{E}+01$ \\
\hline${ }^{239} \mathrm{Pu}$ & $7.65 \mathrm{E}+06$ & $3.2 \mathrm{E}-05$ & $2.45 \mathrm{E}+02$ & $4.7 \mathrm{E}-05$ & $3.60 E+02$ \\
\hline $\mathrm{Am}$ & $3.40 \mathrm{E}+07$ & $2.7 \mathrm{E}-(05$ & $9.18 \mathrm{E}+02$ & $3.9 \mathrm{E}-05$ & $1.33 E+03$ \\
\hline${ }^{244} \mathrm{Cm}$ & $1.22 \mathrm{E}+05$ & $1.7 \mathrm{E}-05$ & $2.07 \mathrm{E}-00$ & $2.5 \mathrm{E}-05$ & $3.05 \mathrm{E}-00$ \\
\hline Total & $4.38 \mathrm{E}+07$ & & $1.22 \mathrm{E}+03$ & & $1.77 E+03$ \\
\hline \multicolumn{3}{|c|}{ Effective DCF ( $\mathrm{Sv} / \mathrm{Bq})$} & $2.79 \mathrm{E}-05$ & & $4.04 \mathrm{E}-05$ \\
\hline
\end{tabular}


Table B3-2. Calculation of Effective Dose Conversion Factor for the Onsite Worker. (2 shects)

\begin{tabular}{|c|c|c|c|c|c|}
\hline \multirow[b]{2}{*}{ Isotope } & \multirow{2}{*}{$\begin{array}{l}\text { Activity/L } \\
\text { (Bq/L) }\end{array}$} & \multicolumn{2}{|c|}{ 5- $\mu \mathrm{m}$ AMAD } & \multicolumn{2}{|c|}{ 1- $\mu \mathrm{m}$ AMAD } \\
\hline & & $\begin{array}{c}\text { DCF } \\
(\mathrm{Sv} / \mathrm{Bq})\end{array}$ & $\begin{array}{c}\text { DCF Activity } \\
\text { (Sv/L) }\end{array}$ & $\begin{array}{c}\text { DCF } \\
(\mathrm{Sv} / \mathrm{Bq})\end{array}$ & $\begin{array}{c}\text { DCF }^{*} \text { Activity } \\
\text { (Sv/L) }\end{array}$ \\
\hline \multicolumn{6}{|c|}{ Effective DCF for Double-Shell Tank Solids } \\
\hline${ }^{237} \mathrm{~Np}$ & $8.11 E+05$ & $1.5 \mathrm{E}-05$ & $1.22 \mathrm{E}+01$ & $2.1 \mathrm{E}-05$ & $1.70 \mathrm{E}+01$ \\
\hline $\mathrm{Pu}-238$ & $7.15 E+07$ & $3.0 \mathrm{E}-05$ & $2.15 \mathrm{E}+03$ & $4.3 \mathrm{E}-05$ & $3.07 \mathrm{E}+03$ \\
\hline${ }^{239} \mathrm{Pu}$ & $1.57 \mathrm{E}+09$ & $3.2 \mathrm{E}-05$ & $5.02 \mathrm{E}+04$ & $4.7 \mathrm{E}-05$ & $7.38 \mathrm{E}+04$ \\
\hline${ }^{241} \mathrm{Am}$ & $2.71 \mathrm{E}+09$ & $2.7 \mathrm{E}-05$ & $7.32 \mathrm{E}+04$ & $3.9 \mathrm{E}-05$ & $1.06 \mathrm{E}+05$ \\
\hline${ }^{244} \mathrm{Cm}$ & $1.64 \mathrm{E}+07$ & $1.7 \mathrm{E}-05$ & $2.79 \mathrm{E}+02$ & $2.5 \mathrm{E}-05$ & $4.10 \mathrm{E}+02$ \\
\hline Total & $4.37 \mathrm{E}+09$ & & $1.26 \mathrm{E}+05$ & & $1.83 \mathrm{E}+05$ \\
\hline \multicolumn{3}{|c|}{ Effective DCF (Sv/Bq) } & $2.88 \mathrm{E}-05$ & & $4.19 \mathrm{E}-05$ \\
\hline
\end{tabular}

Note: DCF are calculated using methodology from ICRP-68, 1994, Dose Coefficients for Intakes of Radionuclides by. Workers-Replacement of ICRP Publication 6I. Annals of the International Commission on Radiation Protection, Volume 24, Number 4, Elsevier Science, Tarrytown, New York.

AMAD - activity median aerodynamic diameter.

$\mathrm{DC} F=-$ dose conversion factor.

Table B3-3. Calculation of Effective Alpha Dose Conversion Factors for Offsite Receptors. (2 sheets)

\begin{tabular}{|c|c|c|c|}
\hline Isotope & $\begin{array}{l}\text { Activity/L } \\
\text { (Bq/L) }\end{array}$ & $\begin{array}{c}\text { ICRP-71* DCF } \\
(\mathrm{Sv} / \mathrm{Bq})\end{array}$ & $\begin{array}{l}\text { DCF Activity } \\
(\mathrm{Sv} / \mathrm{L})\end{array}$ \\
\hline \multicolumn{4}{|c|}{ Effective DCF for Single-Shell Tank Liquids } \\
\hline${ }^{237} \mathrm{~Np}$ & $0.00 \mathrm{E}+00$ & $2.3 \mathrm{E}-05$ & $0.00 \mathrm{E}+00$ \\
\hline${ }^{238} \mathrm{Pu}$ & $9.21 \mathrm{E}+04$ & $4.6 \mathrm{E}-05$ & 4.24 E-00 \\
\hline${ }^{239} \mathrm{Pu}$ & $3.62 \mathrm{E}+07$ & $5.0 \mathrm{E}-05$ & $1.81 \mathrm{E}+03$ \\
\hline${ }^{241} \mathrm{Am}$ & $4.23 \mathrm{E}+07$ & $4.2 \mathrm{~F}-05$ & $1.78 \mathrm{E}+03$ \\
\hline${ }^{244} \mathrm{Cm}$ & $4.23 \mathrm{E}+05$ & $2.7 \mathrm{E}-05$ & $1.14 \mathrm{E}+01$ \\
\hline Total & $7.90 \mathrm{E}+07$ & & $3.60 \mathrm{E}+03$ \\
\hline \multicolumn{3}{|c|}{ Effective DCF (Sv/Bq) } & $4.56 \mathrm{E}-05$ \\
\hline
\end{tabular}


Table B3-3. Calculation of Effective Alpha Dose Conversion Factors for Offsite Receptors. (2 sheets)

\begin{tabular}{|c|c|c|c|}
\hline Isotope & $\begin{array}{l}\text { Activity/L } \\
\text { (Bq/L) }\end{array}$ & $\begin{array}{c}\text { ICRP-71*DCF } \\
(\mathrm{Sv} / \mathrm{Bq})\end{array}$ & $\begin{array}{c}\text { DCF Activity } \\
(\mathrm{Sv} / \mathrm{L})\end{array}$ \\
\hline \multicolumn{4}{|c|}{ Effective DCF for Single-Shell Tank Solids } \\
\hline${ }^{237} \mathrm{~Np}$ & $3.02 \mathrm{E}+07$ & $2.3 \mathrm{E}-05$ & $6.95 \mathrm{E}+02$ \\
\hline${ }^{238} \mathrm{Pu}$ & $1.87 \mathrm{E}+08$ & $4.6 \mathrm{E}-05$ & $8.60 \mathrm{E}+03$ \\
\hline${ }^{239} \mathrm{Pu}$ & $4.40 \mathrm{E}+08$ & $5.0 \mathrm{E}-05$ & $2.20 E+04$ \\
\hline${ }^{241} \mathrm{Am}$ & $2.29 \mathrm{E}+08$ & $4.2 \mathrm{E}-05$ & $9.62 \mathrm{E}+03$ \\
\hline${ }^{244} \mathrm{Cm}$ & $2.29 \mathrm{E}+06$ & $2.7 \mathrm{E}-05$ & $6.18 \mathrm{E}+01$ \\
\hline Total & $8.88 \mathrm{E}+08$ & & $4.10 \mathrm{E}+04$ \\
\hline \multicolumn{3}{|c|}{ Effective DCF (Sv/Bq) } & $4.61 \mathrm{E}-05$ \\
\hline \multicolumn{4}{|c|}{ Effective DCF for Double-Shell Tank Liquids } \\
\hline${ }^{237} \mathrm{~Np}$ & $2.30 \mathrm{E}+05$ & $2.3 \mathrm{E}-(05$ & $5.29 \mathrm{E}-00$ \\
\hline${ }^{2.8} \mathrm{Pu}$ & $1.78 \mathrm{E}+06$ & $4.6 \mathrm{E}-05$ & $8.19 \mathrm{E}+01$ \\
\hline${ }^{239} \mathrm{Pu}$ & $7.65 \mathrm{E}+06$ & $5.0 \mathrm{E}-05$ & $3.83 \mathrm{E}+02$ \\
\hline${ }^{241} \mathrm{Am}$ & $3.40 \mathrm{E}+07$ & $4.2 \mathrm{E}-05$ & $1.43 \mathrm{E}+03$ \\
\hline${ }^{244} \mathrm{Cm}$ & $1.22 \mathrm{E}+05$ & $2.7 \mathrm{E}-0) 5$ & $3.29 \mathrm{E}-00$ \\
\hline Total & $4.38 \mathrm{E}+07$ & & $1.90 \mathrm{E}+03$ \\
\hline \multicolumn{3}{|c|}{ Effective DCF (Sv/Bq) } & $4.34 \mathrm{E}-05$ \\
\hline \multicolumn{4}{|c|}{ Effective DCF for Double-Shell Tank Solids } \\
\hline${ }^{237} \mathrm{~Np}$ & $8.11 \mathrm{E}+05$ & $2.3 \mathrm{E}-05$ & $1.87 \mathrm{E}+01$ \\
\hline${ }^{238} \mathrm{Pu}$ & $7.15 \mathrm{E}+07$ & $4.6 \mathrm{E}-05$ & $3.29 E+03$ \\
\hline${ }^{239} \mathrm{Pu}$ & $1.57 E+09$ & $5.0 \mathrm{E}-05$ & $7.85 \mathrm{E}+04$ \\
\hline Am-241 & $2.71 \mathrm{E}+09$ & $4.2 \mathrm{E}-05$ & $1.14 \mathrm{E}+05$ \\
\hline $\mathrm{Cm}-244$ & $1.64 \mathrm{E}+07$ & $2.7 \mathrm{E}-05$ & $4.43 \mathrm{E}+02$ \\
\hline Total & $4.37 \mathrm{E}+09$ & & $1.96 \mathrm{E}+05$ \\
\hline \multicolumn{3}{|c|}{ Effective DCF $(\mathrm{Sv} / \mathrm{Bq})$} & $4.49 \mathrm{E}-05$ \\
\hline
\end{tabular}

*ICRP-71, 1995, Age Dependent Doses to Members of the Public from Intake of Radionuclides Part 4 Inhalation Dose Coefficients, Annals of the International Commission on Radiation Protection, Volume 25, Number 3-4, Elsevier Science, Tarrytown, New York.

$\mathrm{DCF}-$ dose conversion factor. 


\section{B4.0 CONTRIBUTIONS FROM INGESTION, RESUSPENSION, AND GROUND SHINE}

A method for calculating ULDs that includes the contributions of ingestion and ground shine was developed. This method assumes a 24-hour dose would occur before any food interdiction and/or other corrective actions could be taken. The 24-hour ingestion dose is calculated assuming an acute, maximum individual scenario in which the receptor is assumed to remain at an agricultural residence for 24 hours following the passage of the radioactive plume. No direct doses from the plume itself (i.e., inhalation and submersion) are included. The only contaminated food the receptor is assumed to consume during the first 24 hours is freshly contaminated vegetables and fruit (with holdup times set to zero). There is enough delay in preparation of grains (c.g., making it into bread), and in uptake and incorporation of contamination by animals, that no consumption of contamination from these sources is expected. The exposure pathways included are ground shine, inhalation (resuspended material only), terrestrial food ingestion (leafy vegetables and other vegetables and fruit), and inadvertent soil ingestion. The calculations were made using the GENII computer code (PNL-6584). Ingestion was calculated using the autumn scason, which maximizes the ingestion dose.

The inhalation and ingestion ULDs calculated in WHC-SD-WM-SARR-016 based on worst-case tank inventories are shown in Table B4-1.

B4-1. Fractional Contribution for Twenty-Four-Hour Ingestion.

\begin{tabular}{|c|c|c|c|}
\hline Composite & $\begin{array}{c}\text { Inhalation ULD } \\
(\mathrm{Sv} / \mathrm{L})\end{array}$ & $\begin{array}{l}\text { Ingestion ULD* } \\
\left(\mathrm{Sv}-\mathrm{m}^{3} / \mathrm{s}-\mathbf{L}\right)\end{array}$ & $\begin{array}{l}\text { Ingestion ULD Divided by } \\
\text { Inhalation ULD Times } \\
\text { Breathing Rate }\end{array}$ \\
\hline Single-shell tank liquids & $1.1 \mathrm{E}+(04$ & 0.052 & 0.018 \\
\hline Single-shell tank solids & $2.2 \mathrm{E}+05$ & 4.1 & 0.073 \\
\hline Double-shcll tank liquids & $6.1 \mathrm{E}+03$ & 0.068 & 0.043 \\
\hline Doublc-shell tank solids & $5.3 \mathrm{E}+05$ & 0.48 & 0.0035 \\
\hline
\end{tabular}

*Includes 24 hours of ingestion of fruits and vegetables, ground shine, inadvertent soil ingestion, and inhalation of material resuspended from the ground.

ULD - unit liter dose.

The dose from inhalation is given by

Dose (inhalation) $=\mathrm{Q} \times \mathrm{ULD}($ inhalation $) \times \mathrm{X} / \mathrm{Q}^{\prime} \times \mathrm{BR}$ 
where

$$
\begin{aligned}
& \mathrm{Q}=\text { amount released (liters) } \\
& \mathrm{ULD}=\text { unit liter dose }(\mathrm{Sv} / \mathrm{L}) \\
& \mathrm{X} / \mathrm{Q}^{\prime}=\text { atmospheric dispersion coefficient }\left(\mathrm{s} / \mathrm{m}^{3}\right) \\
& \mathrm{BR}=\text { breathing rate }\left(\mathrm{m}^{3} / \mathrm{s}\right) .
\end{aligned}
$$

The dose from ingestion is given by

$$
\text { Dose (ingestion) }=\mathrm{Q} \times \mathrm{ULD} \text { (ingestion) } \times \mathrm{X} / \mathrm{Q}^{\prime} .
$$

Note that the inhalation and ingestion ULDs are used differently since the dose from inhalation is calculated by multiplying by breathing rate. The total dose is therefore

$$
\begin{aligned}
\text { Dose }(\text { total }) & =\text { Dose }(\text { inhalation })+\text { Dose }(\text { ingestion }) \\
= & \mathrm{Q} \times \mathrm{X} / \mathrm{Q} \times[\{\mathrm{ULD}(\text { inhalation }) \times \mathrm{BR}\}+\mathrm{ULD}(\text { ingestion })]
\end{aligned}
$$

Ingestion doses should be included only for the offsite receptor.

The inclusion of ingestion will increase the offsite doses by only a small amount in most cases. For an acute breathing rate of $2.57 \times 10^{-4} \mathrm{~m}^{3} / \mathrm{s}$, including the ingestion doses increases the total dose from 0.35 to 7.3 percent in all composites based on worst-case tank inventories as analyzed in WHC-SD-WM-SAR-067. It is recognized that the relative values of ingestion and inhalation may change based on ULDs computed on a tank-by-tank basis. However, the tanks with the largest inhalation doses have large contributions from transuranics, which contribute only small ingestion doses. The offsite inhalation doses are increased by a constant factor to compensate for ingestion doses. A factor of 1.1 (10 percent increase in the offsite inhalation doses) is judged adequate to compensate for the ingestion doses based on the data in Table B4-1. The total offsite dose for inhalation plus ingestion is, therefore, given by

$$
\text { Dose }=1.1(\mathrm{Q})\left(\mathrm{X} / \mathrm{Q}^{\prime}\right)(\mathrm{BR})(\mathrm{ULD}) \text {. }
$$

\section{B5.0 ANALYSES SUPPORTING THE SELECTION OF NUCLIDES TO BE USED IN THE DOSE CALCULATIONS}

Calculations with the ORIGEN computer code (ORNL-5621) based on reactor operating histories identified over 100 nuclides that may be present in the tanks. The dose calculations are based on total alpha plus ${ }^{137} \mathrm{Cs},{ }^{90} \mathrm{Sr},{ }^{90} \mathrm{Y}$. It is therefore necessary to justify that the limited selection of nuclides is adequate to support the conclusions in the FSAR (HNF-SD-WM-SAR-067). This section presents data supporting the selection of the nuclides for inhalation, ingestion, and direct external exposure. 
An independent selection of nuclides that would dominate doses has been made based on a calculation of nuclides that were generated in the Hanford Site reactors and are expected to be present in the tank. Calculations for inhalation doses are reported in Section B5.1, and calculations for ingestion doses are reported in Section B5.2. The results support the conclusion that the isotopes selected are the dominant isotopes for both phenomena.

\section{B5.1 INHALATION DOSES}

The isotopes that contribute significantly to the inhalation dose are determined by three factors:

1. The release fraction for the isotope

2. The inventory of the isotope

3. The dose produced by inhalation of a unit quantity of the isotope (i.e., the DCF).

The release fractions for most accident scenarios are taken from DOE-HDBK-3010-94. It is assumed that these release fraction do not vary with isotope for a given accident scenario. The variation in release fraction will therefore be neglected in determining the relative ranking of the isotopes.

A figure of merit for each isotope can be determined by multiplying the isotope inventory by the DCF. This figure of merit can be used to rank the isotopes that contribute most significantly to the inhalation doses. A calculation of tank waste inventories has been made and is documented in WHC-SD-WM-RPT-164, Inventories for Low-Level Waste Tank Waste. The calculation uses the computer code ORIGEN (ORNL-5621) to calculate waste inventories in the tanks. The isotope inventory is based on total radioactive waste generated in the Hanford Site production reactors. Recovery efficiencies of 0.99 are assumed for uranium and 0.995 for plutonium based on historical measurements. The reactor production values for ${ }^{137} \mathrm{Cs}$ were reduced by 0.55 and the values for ${ }^{90} \mathrm{Sr} /{ }^{90} \mathrm{Y}$ were reduced by 0.77 to account for removal of these isotopes from the tanks. The cesium and strontium isotopes that were removed have been encapsulated and are now stored in basins at the Waste Encapsulation and Storage Facility. Recent information indicates the ${ }^{244} \mathrm{Cm}$ data has been overpredicted by ORIGEN by a factor of 8.64

(Schwartz 1996). The ${ }^{244} \mathrm{Cm}$ concentration in Table B5-1 is therefore a factor of 8.64 lower than that given in WHC-SD-WM-RPT-164.

DCFs are taken from ICRP-72. A solubility class of " $M$ " was chosen for most nuclides, which is recommended by ICRP-71 when no additional data are available. Solubility class "F" was used for cesium isotopes as recommended in ICRP-71. The inhalation DCFs are multiplied by the inventories for all isotopes with an inventory of $1 \mathrm{Ci}$ or more. The isotopes, $\mathrm{DCFs}$, and products are shown in Table B5-1 for all isotopes with an inventory of more than $1 \mathrm{Ci}$.

The data in Table B5-1 are in descending order by products of inventory times DCF (column 4). Since the activities are in curies and the DCFs are in sieverts per bequerel, the product is multiplied by $3.7 \times 10^{10} \mathrm{~Bq} / \mathrm{Ci}$ to put the numbers on a consistent unit basis. Column 5 contains the quotient of each entry in column 4 divided by the sum of column 4 entries. The sum of the column 4 entries is the dose from inhalation of the entire inventory of the tank farms. The 
column 5 numbers are therefore a fraction of the total dose contributed by cach isotope.

Column 6 is a running sum of column 5 , giving the cumulative dose fraction in descending order. That is, the ${ }^{10} \mathrm{Sr}$ dose is 37.1 percent of the total dose, and the ${ }^{23.1} \mathrm{Pu}$ dose is 26.4 percent of the total dose. The total fraction of the dose from these two isotopes is therefore 63.5 percent of the total as listed in column 6.

Column 7 contains a marker identifying key isotopes used in WHC-SD-WM-SARR-016. A "T" indicates that this isotope is one of the three isotopes that are tracked in detail in WHC-SD-WM-ER-400, Tank Waste Source Term Inventory Validation. A "G" indicates that the isotope is one of the other isotopes that emits alpha particles and is therefore included in gross alpha. The following conclusions can be drawn from the Table B5-1.

- The tracking of yross alpha plus the three isotopes covers about 97 percent of the total dose.

- The difference in the dose is much less than the conservatism associated with development of the source term and release fractions. Neglecting the isotopes not included the tracked list will not affect the conclusion that the FSAR dose calculations bound actual conditions in the tanks.

Table B5-1. Relative Inhalation Doses from Isotopes Based on ORIGEN Prediction of Tank Inventories. (4 sheets)

\begin{tabular}{|c|c|c|c|c|c|c|}
\hline Isotope & $\begin{array}{l}\text { Activity } \\
\text { (Ci) }\end{array}$ & $\begin{array}{c}\text { ICRP-71 }^{\text {a }} \\
\text { DCF } \\
(\mathrm{Sv} / \mathrm{Bq})\end{array}$ & $\begin{array}{c}\text { DCF } \times \\
\text { Activity } \\
\text { (Sv) }\end{array}$ & $\begin{array}{l}\text { DCF } \times \text { Activity } \\
\text { Divided by } \\
\text { Sum of } \\
\text { DCF } \times \text { Activity }\end{array}$ & $\begin{array}{c}\text { Fraction of } \\
\text { DCF } \times \text { Activity } \\
\text { Divided by } \\
\text { Total } \\
\text { DCF } \times \text { Activity }\end{array}$ & $\begin{array}{c}\text { Key } \\
\text { Isotope }^{b}\end{array}$ \\
\hline${ }^{90} \mathrm{Sr}$ & $8.64 \mathrm{E}+07$ & $3.60 \mathrm{E}-08$ & $1.15 \mathrm{E}+11$ & $3.71 \mathrm{E}-01$ & 0.37110 & $\mathrm{~T}$ \\
\hline${ }^{239} \mathrm{Pu}$ & $4.43 E+04$ & $5.00 \mathrm{E}-05$ & $8.20 E+10$ & $2.64 \mathrm{E}-01$ & 0.63547 & $\mathrm{G}$ \\
\hline $\mathrm{Am}$ & $5.18 \mathrm{E}+04$ & $4.20 \mathrm{E}-05$ & $8.06 \mathrm{E}+10$ & $2.60 \mathrm{E}-01$ & 0.89526 & $\mathrm{G}$ \\
\hline${ }^{137} \mathrm{Cs}$ & $7.16 \mathrm{E}+07$ & $4.60 \mathrm{E}-09$ & $1.22 E+10$ & $3.93 \mathrm{E}-02$ & 0.93453 & $\mathrm{~T}$ \\
\hline${ }^{241} \mathrm{Pu}$ & $1.48 \mathrm{E}+05$ & $9.00 \mathrm{E}-07$ & $4.94 \mathrm{E}+09$ & $1.59 \mathrm{E}-02$ & 0.95046 & \\
\hline${ }^{90} \mathrm{Y}$ & $8.64 \mathrm{E}+07$ & $1.40 \mathrm{E}-09$ & $4.48 \mathrm{E}+09$ & $1.44 \mathrm{E}-02$ & 0.96489 & $T$ \\
\hline${ }^{2.8} \mathrm{Pu}$ & $2.52 \mathrm{E}+03$ & $4.60 \mathrm{E}-05$ & $4.29 E+(09$ & $1.38 \mathrm{E}-02$ & 0.97872 & $\mathrm{G}$ \\
\hline${ }^{1+4} \mathrm{Ce}$ & $8.27 E+05$ & $3.60 \mathrm{E}-08$ & $1.10 \mathrm{E}+09$ & $3.55 \mathrm{E}-03$ & 0.98228 & \\
\hline${ }^{14} \mathrm{Pm}$ & $5.48 E+00$ & $5.00 \mathrm{E}-09$ & $1.01 \mathrm{E}+09$ & $3.27 \mathrm{E}-0.3$ & 0.98555 & \\
\hline${ }^{231} \mathrm{~Pa}$ & $1.45 \mathrm{E}+02$ & $1.40 \mathrm{E}-04$ & $7.52 \mathrm{E}+08$ & $2.43 \mathrm{E}-03$ & 0.98797 & G \\
\hline${ }^{106} \mathrm{Ru}$ & $6.36 \mathrm{E}+05$ & $2.80 \mathrm{E}-08$ & $6.59 \mathrm{E}+08$ & $2.12 \mathrm{E}-03$ & 0.99010 & \\
\hline${ }^{27} \mathrm{Ac}$ & $7.52 \mathrm{E}+01$ & $2.20 \mathrm{E}-04$ & $6.12 \mathrm{E}+08$ & $1.97 \mathrm{E}-03$ & 0.99207 & G \\
\hline${ }^{151} \mathrm{Sm}$ & $3.68 E+06$ & $4.00 \mathrm{E}-0 \mathrm{9}$ & $5.45 E+08$ & $1 . \overline{76 E-03}$ & 0.99383 & \\
\hline
\end{tabular}


Table B5-1. Relative Inhalation Doses from Isotopes Based on ORIGEN Prediction of Tank Inventories. (4 shects)

\begin{tabular}{|c|c|c|c|c|c|c|}
\hline Isotope & $\begin{array}{l}\text { Activity } \\
\text { (Ci) }\end{array}$ & $\begin{array}{c}\text { ICRP-71 }^{\mathrm{a}} \\
\text { DCF } \\
(\mathrm{Sv} / \mathrm{Bq})\end{array}$ & $\begin{array}{c}\text { DCF x } \\
\text { Activity } \\
\text { (Sv) }\end{array}$ & $\begin{array}{c}\text { DCF } \times \text { Activity } \\
\text { Divided by } \\
\text { Sum of } \\
\text { DCF } \times \text { Activity }\end{array}$ & $\begin{array}{c}\text { Fraction of } \\
\text { DCF } \times \text { Activity } \\
\text { Divided by } \\
\text { Total } \\
\text { DCF } \times \text { Activity }\end{array}$ & Key $_{\text {Isotope }^{b}}$ \\
\hline${ }^{244} \mathrm{Cm}$ & $4.68 E+02$ & $2.70 \mathrm{E}-05$ & $4.68 \mathrm{E}+08$ & $1.51 \mathrm{E}-03$ & 0.99533 & $\mathrm{G}$ \\
\hline${ }^{154} \mathrm{Eu}$ & $2.32 \mathrm{E}+05$ & $5.30 \mathrm{E}-08$ & $4.54 \mathrm{E}+08$ & $1.46 \mathrm{E}-0) 3$ & 0.99680 & \\
\hline${ }^{242} \mathrm{mAm}$ & $1.86 \mathrm{E}+02$ & $3.70 \mathrm{E}-05$ & $2.54 \mathrm{E}+08$ & $8.19 \mathrm{E}-04$ & 0.99762 & $G$ \\
\hline $228 \mathrm{Th}$ & $1.21 \mathrm{E}+02$ & $3.20 \mathrm{E}-05$ & $1.43 \mathrm{E}+08$ & $4.62 \mathrm{E}-04$ & 0.99808 & $\mathrm{G}$ \\
\hline${ }^{377} \mathrm{~Np}$ & $7.45 \overline{\mathrm{E}+01}$ & $2.30 \mathrm{E}-05$ & $6.34 \mathrm{E}+07$ & $2.04 \mathrm{E}-04$ & 0.99828 & $\mathrm{G}$ \\
\hline${ }^{134} \mathrm{Cs}$ & $2.54 \mathrm{E}+05$ & $6.60 \mathrm{E}-09$ & $6.20 E+07$ & $2.00 \mathrm{E}-04$ & 0.99848 & \\
\hline${ }^{125} \mathrm{Sb}$ & $3.40 \mathrm{E}+05$ & $4.80 \mathrm{E}-09$ & $6.04 E+07$ & 1.95 E-04 & 0.99868 & \\
\hline $2 \sqrt[33]{\mathrm{U}}$ & $4.30 \mathrm{E}+02$ & $3.60 \mathrm{E}-06$ & $5.73 E+07$ & $1.85 \mathrm{E}-04$ & 0.99886 & $\mathrm{G}$ \\
\hline${ }^{243} \mathrm{Am}$ & $3.39 \mathrm{E}+01$ & $4.10 \mathrm{E}-05$ & $5.14 E+07$ & $1.66 \mathrm{E}-04$ & 0.99903 & $\mathrm{G}$ \\
\hline${ }^{155} \mathrm{Eu}$ & $1.99 \mathrm{E}+05$ & $6.90 \mathrm{E}-09$ & $5.07 \mathrm{E}+07$ & $1.63 \mathrm{E}-04$ & 0.99919 & \\
\hline $113 \mathrm{~m} \mathrm{Cd}$ & $2.61 \mathrm{E}+04$ & $5.20 \mathrm{E}-08$ & $5.02 \mathrm{E}+07$ & $1.62 \mathrm{E}-04$ & 0.99935 & \\
\hline${ }^{234} \mathrm{U}$ & $2.99 \mathrm{E}+02$ & $3.50 \mathrm{E}-06$ & $3.87 \mathrm{E}+07$ & $1.25 \mathrm{E}-04$ & 0.99948 & \\
\hline${ }^{232} \mathrm{U}$ & $1.15 \mathrm{E}+02$ & $7.80 \mathrm{E}-06$ & $3.30 \mathrm{E}+07$ & $1.07 \mathrm{E}-04$ & 0.99959 & $\mathrm{G}$ \\
\hline${ }^{23 x} \mathrm{U}$ & $2.96 \mathrm{E}+02$ & $2.90 \mathrm{E}-06$ & $3.18 \mathrm{E}+07$ & $1.02 \mathrm{E}-04$ & 0.99969 & \\
\hline${ }^{227} \mathrm{Th}$ & $7.41 \mathrm{E}+01$ & $8.50)$ E- 06 & $2.33 \mathrm{E}+07$ & $7.52 \mathrm{E}-05$ & 0.99976 & $G$ \\
\hline${ }^{223} \mathrm{Ra}$ & $7.52 \mathrm{E}+01$ & $7.40 \mathrm{E}-06$ & $2.06 \mathrm{E}+07$ & $6.64 \mathrm{E}-05$ & 0.99983 & \\
\hline${ }^{224} \mathrm{Ra}$ & $1.21 \mathrm{E}+02$ & $3.00 \mathrm{E}-06$ & $1.34 \mathrm{E}+07$ & $4.33 \mathrm{E}-05$ & 0.90987 & \\
\hline${ }^{12.5 \mathrm{~m}} \mathrm{Te}$ & $8.28 \mathrm{E}+04$ & $3.40 \mathrm{E}-09$ & $1.04 \mathrm{E}+07$ & $3.36 \mathrm{E}-05$ & 0.99991 & \\
\hline${ }^{232} \mathrm{Th}$ & $2.68 \mathrm{E}+00$ & $4.50 \mathrm{E}-05$ & $4.47 \mathrm{E}+06$ & $1.44 \mathrm{E}-05$ & 0.99092 & G \\
\hline${ }^{14)} \mathrm{Tc}$ & $2.74 \mathrm{E}+04$ & $4.00 \mathrm{E}-09$ & $4.06 \mathrm{E}+06$ & $1.31 \mathrm{E}-05$ & 0.99993 & \\
\hline${ }^{152} \mathrm{Eu}$ & $2.57 \mathrm{E}+03$ & $4.20 \mathrm{E}-08$ & $3.99 \mathrm{E}+06$ & $1.29 \mathrm{E}-05$ & 0.99995 & \\
\hline${ }^{24} \mathrm{Cm}$ & $1.64 \mathrm{E}+01$ & $5.20 \mathrm{E}-06$ & $3.16 \mathrm{E}+06$ & $1.02 \mathrm{E}-05$ & 0.99996 & G \\
\hline${ }^{6,1)} \mathrm{Co}$ & $9.24 \mathrm{E}+03$ & $1.00 \mathrm{E}-08$ & $2.77 \mathrm{E}+06$ & $8.94 \mathrm{E}-06$ & 0.99997 & \\
\hline${ }^{93} \mathrm{Zr}$ & $5.04 \mathrm{E}+03$ & $1.00 \mathrm{E}-08$ & $1.86 \mathrm{E}+06$ & $6.01 \mathrm{E}-06$ & 0.99997 & \\
\hline${ }^{243} \mathrm{Cm}$ & $1.56 \mathrm{E}+00$ & $3.10 \mathrm{E}-05$ & $1.79 \mathrm{E}+06$ & $5.77 \mathrm{E}-06$ & 0.99998 & $\mathrm{G}$ \\
\hline${ }^{26} \mathrm{Sn}$ & $1.58 \mathrm{E}+05$ & $2.80 \mathrm{E}-08$ & $1.64 E+06$ & $5.28 \mathrm{E}-06$ & 0.99998 & \\
\hline $235 \mathrm{U}$ & $1.22 \mathrm{E}+01$ & $3.10 \mathrm{E}-06$ & $1.40 \mathrm{E}+06$ & $4.51 \mathrm{E}-06$ & 0.99099 & \\
\hline${ }^{21} 2 \mathrm{~Pb}$ & $1.21 \mathrm{E}+02$ & $1.70 \mathrm{E}-07$ & $7.61 E+05$ & $2.45 \mathrm{E}-06$ & 0.99999 & \\
\hline${ }^{1+4} \mathrm{Pr}$ & $8.27 \mathrm{E}+05$ & $1.80 \mathrm{E}-11$ & $5.51 \mathrm{E}+05$ & $1.78 \mathrm{E}-06$ & 0.99999 & \\
\hline
\end{tabular}


Table B5-1. Relative Inhalation Doses from Isotopes Based on

ORIGEN Prediction of Tank Inventories. (4 shects)

\begin{tabular}{|c|c|c|c|c|c|c|}
\hline Isotope & $\begin{array}{c}\text { Activity } \\
\text { (Ci) }\end{array}$ & $\begin{array}{c}\text { ICRP-71 }^{\mathrm{a}} \\
\text { DCF } \\
(\mathrm{Sv} / \mathrm{Bq})\end{array}$ & $\begin{array}{c}\text { DCF } \times \\
\text { Activity } \\
\text { (Sv) }\end{array}$ & $\begin{array}{c}\text { DCF } \times \text { Activity } \\
\text { Divided by } \\
\text { Sum of } \\
\text { DCF } \times \text { Activity }\end{array}$ & $\begin{array}{c}\text { Fraction of } \\
\text { DCF } \times \text { Activity } \\
\text { Divided by } \\
\text { Total } \\
\text { DCF } \times \text { Activity }\end{array}$ & $\begin{array}{c}\text { Key } \\
\text { Isotope }^{b}\end{array}$ \\
\hline${ }^{3} \mathrm{H}$ & $2.74 \mathrm{E}+05$ & $4.50 \mathrm{E}-11$ & $4.57 \mathrm{E}+05$ & $1.47 \mathrm{E}-06$ & 0.99999 & \\
\hline${ }^{119 m} \mathrm{Sn}$ & $6.22 \mathrm{E}+03$ & $2.20 \mathrm{E}-09$ & $4.11 \mathrm{E}+05$ & $1.32 \mathrm{E}-06$ & 0.99999 & \\
\hline${ }^{228} \mathrm{Ra}$ & $3.30 \mathrm{E}+00$ & $2.60 \mathrm{E}-06$ & $3.17 \mathrm{E}+05$ & $1.02 \mathrm{E}-06$ & 1.00000 & $\mathrm{G}$ \\
\hline${ }^{6} \cdot \mathrm{Ni}$ & $1.91 E+04$ & $4.80 \mathrm{E}-10$ & $2.74 E+05$ & $8.85 \mathrm{E}-07$ & 1.00000 & \\
\hline${ }^{55} \mathrm{Fe}$ & $1.89 \mathrm{E}+04$ & $3.80 \mathrm{E}-10$ & $2.16 \mathrm{E}+05$ & $9.96 \mathrm{E}-07$ & 1.00000 & \\
\hline${ }^{212} \mathrm{Bi}$ & $1.21 \mathrm{E}+02$ & $3.10 \mathrm{E}-08$ & $1.39 \mathrm{E}+05$ & $4.48 \mathrm{E}-(07$ & 1.00000 & \\
\hline${ }^{242} \mathrm{Am}$ & $1.85 \mathrm{E}+02$ & $1.70 \mathrm{E}-08$ & $1.16 \mathrm{E}+05$ & $3.75[\mathrm{E}-07$ & 1.00000 & \\
\hline${ }^{79} \mathrm{Se}$ & $1.03 E+03$ & $2.60 \mathrm{E}-09$ & $9.90 \mathrm{E}+04$ & $3.19 \mathrm{E}-07$ & 1.00000 & \\
\hline${ }^{234} \mathrm{Th}$ & $2.96 \mathrm{E}+02$ & $6.60 \mathrm{E}-09$ & $7.23 \mathrm{E}+04$ & $2.33 \mathrm{E}-07$ & 1.00000 & \\
\hline${ }^{9.3 \mathrm{mb}} \mathrm{Nb}$ & $3.46 \mathrm{E}+03$ & $5.10 \mathrm{E}-10$ & $6.53 E+04$ & $2.11 \mathrm{E}-07$ & 1.00000 & \\
\hline${ }^{14} \mathrm{C}$ & $7.45 \mathrm{E}+02$ & $2.00 \mathrm{E}-09$ & $5.51 \mathrm{E}+04$ & $1.78 \mathrm{E}-07$ & 1.00000 & \\
\hline${ }^{129} I$ & $6.62 \mathrm{E}+01$ & $1.50 \mathrm{E}-08$ & $3.67 \mathrm{E}+04$ & $1.18 \mathrm{E}-07$ & 1.00000 & \\
\hline${ }^{146} \mathrm{Pm}$ & $4.41 \mathrm{E}+01$ & $2.10 \mathrm{E}-08$ & $3.43 \mathrm{E}+04$ & $1.10 \mathrm{E}-07$ & 1.00000 & \\
\hline${ }^{211} \mathrm{~Pb}$ & $7.52 \mathrm{E}+01$ & $1.10 \mathrm{E}-08$ & $3.06 \mathrm{E}+04$ & $9.87 \mathrm{E}-08$ & 1.00000 & \\
\hline${ }^{135} \mathrm{Cs}$ & $1.09 \mathrm{E}+03$ & $6.90 \mathrm{E}-10$ & $2.77 \mathrm{E}+04$ & $8.94 \mathrm{E}-08$ & 1.00000 & \\
\hline${ }^{110 \mathrm{~m}} \mathrm{Ag}$ & $9.82 \mathrm{E}+01$ & $7.60 \mathrm{E}-09$ & $2.76 \mathrm{E}+04$ & $8.90 \mathrm{E}-08$ & 1.00000 & \\
\hline${ }^{126} \mathrm{Sb}$ & $2.21 \mathrm{E}+02$ & $2.80 \mathrm{E}-09$ & $2.29 \mathrm{E}+04$ & $7.38 \mathrm{E}-08$ & 1.00000 & \\
\hline${ }^{12 ! m} \mathrm{Sn}$ & $8.60 \mathrm{E}+01$ & $4.50 \mathrm{E}-09$ & $1.16 \mathrm{E}+04$ & $3.74 \mathrm{E}-08$ & 1.00000 & \\
\hline${ }^{233} \mathrm{~Pa}$ & $7.48 \mathrm{E}+01$ & $3.30 \mathrm{E}-09$ & $9.14 \mathrm{E}+03$ & $2.95 \mathrm{E}-08$ & 1.00000 & \\
\hline${ }^{234 n} \mathrm{~Pa}$ & $2.96 \mathrm{E}+02$ & $3.80 \mathrm{E}-10$ & $4.16 E+03$ & $1.34 \mathrm{E}-08$ & 1.00000 & \\
\hline${ }^{228} \mathrm{Ac}$ & $3.40 \mathrm{E}+00$ & $1.70 \mathrm{E}-08$ & $2.14 \mathrm{E}+03$ & $6.89 \mathrm{E}-09$ & 1.00000 & \\
\hline${ }^{239} \mathrm{~Np}$ & $3.39 \mathrm{E}+01$ & $9.30 \mathrm{E}-10$ & $1.17 \mathrm{E}+03$ & $3.76 \mathrm{E}-09$ & 1.00000 & \\
\hline${ }^{127} \mathrm{Sn}$ & $1.91 \mathrm{E}+02$ & $1.30 \mathrm{E}-10$ & $9.19 E+02$ & $2.96 \mathrm{E}-09$ & 1.000000 & \\
\hline${ }^{59} \mathrm{Ni}$ & $1.86 \mathrm{E}+02$ & $1.30 \mathrm{E}-10$ & $7.25 \mathrm{E}+02$ & $2.34 \mathrm{E}-09$ & 1.00000 & \\
\hline${ }^{231} \mathrm{U}$ & $7.38 \mathrm{E}+02$ & $2.20 \mathrm{E}-11$ & $6.01 \mathrm{E}+02$ & $1.94 \mathrm{E}-09$ & 1.00000 & \\
\hline${ }^{102} \mathrm{Rh}$ & $2.20 \mathrm{E}+00$ & $6.90 \mathrm{E}-09$ & $5.62 \mathrm{E}+02$ & $1.81 \mathrm{E}-09$ & 1.00000 & \\
\hline${ }^{1077} \mathrm{Pd}$ & $1.02 \mathrm{E}+02$ & $8.50 \mathrm{E}-11$ & $3.21 \mathrm{E}+02$ & $1.03 \mathrm{E} .09$ & 1.00000 & \\
\hline${ }^{23} \mathrm{U}$ & $3.67 \mathrm{E}+00$ & $1.70 \mathrm{E}-09$ & $2.31 \mathrm{E}+02$ & $7.44 \mathrm{E}-10$ & 1.00000 & \\
\hline${ }^{231} \mathrm{Th}$ & $1.22 \mathrm{E}+01$ & $3.10 \mathrm{E}-10$ & $1.40 \mathrm{E}+02$ & $4.51 \mathrm{E}-10$ & 1.000000 & \\
\hline
\end{tabular}


Table B5-1. Relative Inhalation Doses from Isotopes Based on ORIGEN Prediction of Tank Inventories. (4 sheets)

\begin{tabular}{|l|c|c|c|c|c|c|}
\hline Isotope & $\begin{array}{c}\text { Activity } \\
(\mathbf{C i})\end{array}$ & $\begin{array}{c}\text { ICRP-71 } \\
\text { DCF } \\
(\mathbf{S v} / \mathrm{Bq})\end{array}$ & $\begin{array}{c}\text { DCF } \times \\
\text { Activity } \\
\text { (Sv) }\end{array}$ & $\begin{array}{c}\text { DCF } \times \text { Activity } \\
\text { Divided by } \\
\text { Sum of } \\
\text { DCF } \times \text { Activity }\end{array}$ & $\begin{array}{c}\text { Fraction of } \\
\text { DCF } \times \text { Activity } \\
\text { Divided by } \\
\text { Total } \\
\text { DCF } \times \text { Activity }\end{array}$ & $\begin{array}{c}\text { Key } \\
\text { Isotope }\end{array}$ \\
\hline${ }^{153} \mathrm{Gd}$ & $1.11 \mathrm{E}+00$ & $2.10 \mathrm{E}-09$ & $8.60 \mathrm{E}+01$ & $2.77 \mathrm{E}-10$ & 1.00000 & \\
\hline${ }^{223} \mathrm{Fr}$ & $1.04 \mathrm{E}+00$ & $8.90 \mathrm{E}-10$ & $3.41 \mathrm{E}+01$ & $1.10 \mathrm{E}-10$ & 1.00000 & \\
\hline
\end{tabular}

Note: These doses are based on predictions of tank inventories created using the ORIGEN computer code, which is documented in ORNI -5621, 1980, ORIGLN2--A Revised and Updated Version of the Oak Ridge Isotope Generation and Depletion Code, Oak Ridge National Laboratory, Oak Ridge, Tennessee.

"ICRP-71, 1995, Age Dependent Doses to Memhers of the Public from Intake of Radionuclides Part 4 Inhakation Dose Coefficients, Annals of the International Commission on Radiation Protection, Volume 25, Number 3-4, Elsevier Science, Tarrytown, New York.

${ }^{\mathrm{b}} \mathrm{I}$ ' indicates an isotope that is tracked, $\mathrm{G}$ indicates isotope is included in gross alpha.

I)CF - dose conversion factor.

\section{B5.2 INGESTION}

A figure of merit was calculated for ingestion doses using a method similar to that used to calculate the inhalation doses except the calculated activity in the tanks was inserted into the GENII code (PNL-6584), and ingestion doses were then calculated based on ingestion of fruits and vegetables. The activities were adjusted as discussed in Section B5.1. The doses were based on the autumn scenario, which maximizes ingestion dose. The ingestion doses were computed using the same assumptions as the 24-hour ingestion dose described in Section B4.0. The dose contribution from leafy vegetables, other vegetables and fruit, and inadvertent soil ingestion were included. The results are shown in Table B5-2. The five most significant isotopes are all tracked isotopes and contribute over 99 percent of the dose. The results support the selection of the isotopes used.

Table B5-2. Relative Ingestion Doses Based on Origin Prediction of Tank Inventory. (4 shects)

\begin{tabular}{|l|c|c|c|c|}
\hline \multicolumn{1}{|c|}{ Nuclide } & $\begin{array}{c}\text { Ingestion Dose } \\
\text { (rem) }\end{array}$ & $\begin{array}{c}\text { Fraction of } \\
\text { Total Dose }\end{array}$ & $\begin{array}{c}\text { Sum of } \\
\text { Fraction of } \\
\text { Total }\end{array}$ & Key Isotope* \\
\hline${ }^{90} \mathrm{Sr}$ & $5.0 \mathrm{E}+06$ & $6.9 \mathrm{E}-01$ & 0.0905 & $\mathrm{~T}$ \\
\hline${ }^{137} \mathrm{Cs}$ & $1.6 \mathrm{E}+06$ & $2.2 \mathrm{E}-01$ & 0.9114 & $\mathrm{~T}$ \\
\hline${ }^{10} \mathrm{Y}$ & $4.4 \mathrm{E}+05$ & $6.1 \mathrm{E}-02$ & 0.9722 & $\mathrm{~T}$ \\
\hline${ }^{241} \mathrm{Am}$ & $9.0 \mathrm{E}+04$ & $1.2 \mathrm{E}-02$ & 0.9846 & $\mathrm{G}$ \\
\hline${ }^{239} \mathrm{Pu}$ & $7.5 \mathrm{E}+04$ & $1.0 \mathrm{E}-02$ & 0.9950 & $\mathrm{G}$ \\
\hline
\end{tabular}


Table B5-2. Relative Ingestion Doses Based on Origin Prediction of Tank Inventory. (4 shects)

\begin{tabular}{|c|c|c|c|c|}
\hline Nuclide & $\begin{array}{c}\text { Ingestion Dose } \\
\text { (rem) }\end{array}$ & $\begin{array}{l}\text { Fraction of } \\
\text { Total Dose }\end{array}$ & $\begin{array}{l}\text { Sum of } \\
\text { Fraction of } \\
\text { Total }\end{array}$ & Key Isotope* \\
\hline${ }^{1.34} \mathrm{Cs}$ & $6.9 E+03$ & $9.5 \mathrm{E}-04$ & 0.9959 & \\
\hline${ }^{106} \mathrm{Ru}$ & $5.9 E+03$ & 8.1 E-04 & 0.9968 & \\
\hline${ }^{144} \mathrm{Ce}$ & $5.5 \mathrm{E}+03$ & $7.6 \mathrm{E}-04$ & 0.9975 & \\
\hline${ }^{241} \mathrm{Pu}$ & $4.7 \mathrm{E}+03$ & $6.5 \mathrm{E}-04$ & 0.9982 & \\
\hline${ }^{238} \mathrm{Pu}$ & $3.8 \bar{E}+03$ & $5.2 \mathrm{E}-04$ & 0.9987 & $\mathrm{G}$ \\
\hline${ }^{147} \mathrm{Pm}$ & $2.4 \mathrm{E}+03$ & $3.3 \mathrm{E}-04$ & 0.9990 & \\
\hline${ }^{113 \mathrm{~m}} \mathrm{Cd}$ & $2.0 \mathrm{E}+03$ & $2.8 E-04$ & 0.9993 & \\
\hline${ }^{154} \mathrm{Eu}$ & $1.0 \mathrm{E}+03$ & $1.4 \mathrm{E}-04$ & 0.9994 & \\
\hline${ }^{231} \mathrm{~Pa}$ & $7.0 \mathrm{E}+02$ & $9.7 E-05$ & 0.9995 & \\
\hline${ }^{151} \mathrm{Sm}$ & $6.8 \mathrm{E}+02$ & $9.4 \mathrm{E}-05$ & 0.9996 & \\
\hline${ }^{227} \mathrm{Ac}$ & $5.0 \mathrm{E}+02$ & $6.9 \mathrm{E}-05$ & 0.9997 & $\mathrm{G}$ \\
\hline${ }^{244} \mathrm{Cm}$ & $4.4 \mathrm{E}+02$ & $6.1 \mathrm{E}-05$ & 0.9998 & $\bar{G}$ \\
\hline${ }^{12.5} \mathrm{Sb}$ & $4.0 \mathrm{E}+02$ & $5.5 \mathrm{E}-05$ & 0.9998 & \\
\hline${ }^{242} \mathrm{Am}$ & $3.2 \mathrm{E}+02$ & $4.4 \mathrm{E}-(05$ & 0.9998 & $\mathrm{G}$ \\
\hline${ }^{237} \mathrm{~Np}$ & $1.9 \mathrm{E}+02$ & $2.6 \mathrm{E}-05$ & 0.9999 & G \\
\hline${ }^{155} \mathrm{Eu}$ & $1.4 \mathrm{E}+02$ & $1.9 \mathrm{E}-05$ & 0.9999 & \\
\hline${ }^{125 \mathrm{~m}} \mathrm{Te}$ & $1.3 \mathrm{E}+02$ & $1.8 \mathrm{E}-05$ & 0.9999 & \\
\hline${ }^{60} \mathrm{Co}$ & $1.1 \mathrm{E}+02$ & $1.5 \mathrm{E}-05$ & 0.9999 & \\
\hline${ }^{129} \mathrm{I}$ & $7.8 \mathrm{E}+01$ & $1.1 \mathrm{E}-05$ & 0.9999 & \\
\hline${ }^{232} \mathrm{U}$ & $6.8 \mathrm{E}+01$ & $9.4 \mathrm{E}-06$ & 0.9999 & \\
\hline${ }^{233} \mathrm{U}$ & $5.9 \mathrm{E}+01$ & $8.1 \mathrm{E}-06$ & 1.0000 & \\
\hline${ }^{24.3} \mathrm{Am}$ & $5.8 \mathrm{E}+01$ & $8.0 \mathrm{E}-06$ & 1.0000 & G \\
\hline${ }^{234} \mathrm{U}$ & $4.0 \mathrm{E}+01$ & $5.5 \mathrm{E}-06$ & 1.0000 & \\
\hline${ }^{238} \mathrm{U}$ & $3.7 \mathrm{E}+01$ & $5.1 \mathrm{E}-06$ & 1.0000 & \\
\hline${ }^{144} \operatorname{Pr}$ & $3.1 \mathrm{E}+01$ & $4.3 \mathrm{E}-06$ & 1.0000 & \\
\hline${ }^{\prime)} \mathrm{Tc}$ & $2.9 \mathrm{E}+01$ & $4.0 \mathrm{E}-06$ & 1.0000 & \\
\hline${ }^{228} \mathrm{Th}$ & $2.3 \mathrm{E}+01$ & $3.2 \mathrm{E}-06$ & 1.0000 & \\
\hline${ }^{126} \mathrm{Sn}$ & $1.5 \mathrm{E}+01$ & $2.1 \mathrm{E}-06$ & 1.0000 & \\
\hline${ }^{22.3} \mathrm{Ra}$ & $9.4 \mathrm{E}+00$ & $1.3 \mathrm{E}-06$ & 1.0000 & $\mathrm{G}$ \\
\hline${ }^{152} \mathrm{Eu}$ & $7.8 \mathrm{E}+00$ & $1.15-06$ & 1.0000 & \\
\hline${ }^{3} \mathrm{H}$ & $7.6 \mathrm{E}+00$ & $1.0 \mathrm{E}-06$ & 1.0000 & \\
\hline${ }^{224} \mathrm{Ra}$ & $7.4 \mathrm{E}+00$ & $1.0 \mathrm{E}-06$ & 1.0000 & $\mathrm{G}$ \\
\hline
\end{tabular}


Table B5-2. Relative Ingestion Doses Based on Origin Prediction of Tank Inventory. (4 sheets)

\begin{tabular}{|c|c|c|c|c|}
\hline Nuclide & $\begin{array}{l}\text { Ingestion Dose } \\
\text { (rem) }\end{array}$ & $\begin{array}{l}\text { Fraction of } \\
\text { Total Dose }\end{array}$ & $\begin{array}{c}\text { Sum of } \\
\text { Fraction of } \\
\text { Total }\end{array}$ & Key Isotope* \\
\hline${ }^{63} \mathrm{Ni}$ & $5.1 \mathrm{E}+00$ & $7.0 \mathrm{E}-07$ & 1.0000 & \\
\hline${ }^{55} \mathrm{Fe}$ & $4.9 E+00$ & $6.8 \mathrm{E}-\overline{07}$ & 1.0000 & \\
\hline${ }^{242} \mathrm{Cm}$ & $4.7 E+00$ & $6.5 \mathrm{E}-07$ & 1.0000 & $\mathrm{G}$ \\
\hline${ }^{33} \mathrm{Zr}$ & $3.9 \mathrm{E}+00$ & $5.4 \mathrm{E}-07$ & 1.0000 & \\
\hline${ }^{76} \mathrm{Se}$ & $3.9 E+00$ & $5.4 \mathrm{E}-07$ & 1.0000 & \\
\hline${ }^{135} \mathrm{Cs}$ & $3.6 \mathrm{E}+00$ & $5.0 \mathrm{E}-07$ & 1.0000 & \\
\hline${ }^{232} \mathrm{Th}$ & $3.5 \mathrm{E}+00$ & $4.8 \mathrm{E}-07$ & 1.0000 & $\mathrm{G}$ \\
\hline${ }^{212} \mathrm{~Pb}$ & $2.8 E+00$ & $3.9 E-07$ & 1.0000 & \\
\hline${ }^{119 m} \mathrm{Sn}$ & $2.7 \mathrm{E}+00$ & $3.7 \mathrm{E}-07$ & 1.0000 & \\
\hline${ }^{224} \mathrm{Th}$ & $1.9 \mathrm{E}+00$ & $2.6 \mathrm{E}-07$ & 1.0000 & \\
\hline${ }^{243} \mathrm{Cm}$ & $1.9 \mathrm{E}+00$ & $2.6 \mathrm{E}-07$ & 1.0000 & \\
\hline${ }^{235} \mathrm{U}$ & $1.5 \mathrm{E}+00$ & $2.1 \mathrm{E}-07$ & 1.0000 & $\mathrm{G}$ \\
\hline${ }^{227} \mathrm{Th}$ & $1.3 \mathrm{E}+00$ & $1.8 \mathrm{E}-07$ & 1.0000 & \\
\hline${ }^{228} \mathrm{Ra}$ & $1.3 \mathrm{E}+00$ & $1.8 \mathrm{E}-07$ & 1.0000 & \\
\hline${ }^{126} \mathrm{Sb}$ & $1.1 E+00$ & $1.5 \mathrm{E}-07$ & 1.0000 & \\
\hline${ }^{116) m} \mathrm{Ag}$ & $9.9 \mathrm{E}-01$ & $1.4 \mathrm{E}-07$ & 1.0000 & \\
\hline${ }^{33 \mathrm{~m}} \mathrm{Nb}$ & $8.5 \mathrm{E}-01$ & $1.2 \mathrm{E}-07$ & 1.0000 & \\
\hline${ }^{144 m} \mathrm{Pr}$ & $1.8 \mathrm{E}-(01$ & $2.5 \mathrm{E}-(08$ & 1.0000 & \\
\hline${ }^{233} \mathrm{~Pa}$ & $1.3 \mathrm{E}-01$ & $1.8 \mathrm{E}-08$ & 1.0000 & \\
\hline${ }^{242} \mathrm{Am}$ & $1.3 \mathrm{E}-(0) 1$ & $1.8 \mathrm{E}-08$ & 1.0000 & \\
\hline${ }^{107} \mathrm{Pd}$ & $7.1 \mathrm{E}-02$ & $9.8 \mathrm{E}-09$ & 1.0000 & \\
\hline${ }^{126 m} \mathrm{Sb}$ & $6.9 \mathrm{E}-02$ & $9.5 \mathrm{E}-09$ & 1.0000 & \\
\hline${ }^{212} \mathrm{Bi}$ & $6.4 \mathrm{E}-02$ & $8.8 \mathrm{E}-(0 \mathrm{O}$ & 1.0000 & \\
\hline${ }^{121 m} \mathrm{Sn}$ & $6.2 \mathrm{E}-02$ & $8.6 \mathrm{E}-09$ & 1.0000 & \\
\hline${ }^{231} \mathrm{~Np}$ & $5.2 \mathrm{E}-02$ & $7.2 \mathrm{E}-0 \mathrm{9}$ & 1.0000 & \\
\hline${ }^{229} \mathrm{Th}$ & $3.4 \mathrm{E}-02$ & $4.7 \mathrm{E}-09$ & 1.0000 & \\
\hline${ }^{121} \mathrm{Sn}$ & $2.9 \mathrm{E}-02$ & $4.0 \mathrm{E}-09$ & 1.0000 & \\
\hline${ }^{51)} \mathrm{Ni}$ & $1.9 \mathrm{E}-02$ & $2.6 \mathrm{E}-0 \mathrm{9}$ & 1.0000 & \\
\hline${ }^{231} \mathrm{Th}$ & $7.7 \mathrm{E}-03$ & $1.1 \mathrm{E}-09$ & 1.0000 & \\
\hline${ }^{223} \mathrm{Fr}$ & $5.5 \mathrm{E}-(03$ & $7.6 \mathrm{E}-10$ & 1.0000 & \\
\hline $237 \mathrm{U}$ & $5.4 \mathrm{E}-03$ & $7.5 \mathrm{E}-10$ & 1.0000 & \\
\hline $22 \mathrm{Ac}$ & $3.3 \mathrm{E}-03$ & $4.6 \mathrm{E}-10$ & 1.0000 & \\
\hline
\end{tabular}


Table B5-2. Relative Ingestion Doses Based on Origin Prediction of Tank Inventory. (4 sheets)

\begin{tabular}{|l|c|c|c|c|}
\hline \multicolumn{1}{|c|}{ Nuclide } & $\begin{array}{c}\text { Ingestion Dose } \\
\text { (rem) }\end{array}$ & $\begin{array}{c}\text { Fraction of } \\
\text { Total Dose }\end{array}$ & $\begin{array}{c}\text { Sum of } \\
\text { Fraction of } \\
\text { Total }\end{array}$ & Key Isotope* $^{*}$ \\
\hline${ }^{225} \mathrm{Ra}$ & $1.9 \mathrm{E}-03$ & $2.6 \mathrm{E}-10$ & 1.0000 & \\
\hline${ }^{238} \mathrm{~Np}$ & $1.8 \mathrm{E}-03$ & $2.5 \mathrm{E}-10$ & 1.0000 & \\
\hline${ }^{14} \mathrm{C}$ & $1.1 \mathrm{E}-03$ & $1.5 \mathrm{E}-10$ & 1.0000 & \\
\hline${ }^{225} \mathrm{Ac}$ & $8.9 \mathrm{E}-04$ & $1.2 \mathrm{E}-10$ & 1.0000 & \\
\hline${ }^{234} \mathrm{~Pa}$ & $5.0 \mathrm{E}-04$ & $6.9 \mathrm{E}-11$ & 1.0000 & \\
\hline${ }^{153} \mathrm{Gd}$ & $3.8 \mathrm{E}-04$ & $5.2 \mathrm{E}-11$ & 1.0000 & \\
\hline Total & $7.2 \mathrm{E}+06$ & & & \\
\hline
\end{tabular}

* T indicates an isotope that is tracked, $\mathrm{G}$ indicates isotope is included in gross alpha.

\section{B6.0 REFERENCES}

Brevick, C. H., 2000, Updated Calculation Methods for Tank Farm Unit Liter Doses (Attachment to Letter CO-00-RPP-270, Deliverable for Contract 4976, Release 8 , Updated Dose Methods (L-03), to W. L. Cowley, March 27), Fluor Federal Services, Richland, Washington.

DOE-HDBK-3010-94, 1994, Airborne Release Fractions/Rates and Respirable Fractions for Nonreactor Nuclear Facilities, U.S. Department of Encrgy, Washington, D.C.

HNF-4754, 1999, Tank Waste Isotope Contributions, Fluor Danicl Northwest, Richland, Washington.

HNF-SD-WM-SAR-067, 2000, Tank Waste Remediation System Final Safety Analysis Report, Rev. ID, Lockhecd Martin Hanford Corporation, Richland, Washington.

ICRP-26, 1977, Recommendations of the International Commission on Radiological Protection, Annals of the International Commission on Radiation Protection, Volume 1, Number 3. Elsevier Science, Tarrytown, New York.

ICRP-30, 1979, Limits for Intakes of Radionuclides by Workers, Annals of the International Commission on Radiation Protection, Volume 2, Number 3-4, Elsevier Science, Tarrytown, New York.

ICRP-61, 1991. Anmual Limits on Intake of Radionuclides by Workers Based on the 1990 Recommendations, Annals of the International Commission on Radiation Protection, Volume 21, Number 4, Elsevier Science, Tarrytown, New York. 
ICRP-68, 1994, Dose Coefficients for Intakes of Radionuclides by Workers-Replacement of ICRP Publication 61, Annals of the International Commission on Radiation Protection, Volume 24, Number 4, Elsevier Science, Tarrytown, New York.

ICRP-71, 1995, Age Dependent Doses to Members of the Public from Intake of Radionuclides Part 4 Inhalation Dose Coefficients, Annals of the International Commission on Radiation Protection, Volume 25, Number 3-4, Elsevier Science, Tarrytown, New York.

ICRP-72, 1996, Age Dependent Doses to Members of the Public from Intake of Radionuclides Part 5 Compilation of Ingestion and Inhalation Dose Coefficients, Annals of the International Commission on Radiation Protection, Volume 26, Number 1, Elsevier Science, Tarrytown, New York

ORNL-5621, 1980, ORIGEN2-A Revised and Updated Version of the Oak Ridge Isotope Generation and Depletion Code, Oak Ridge National Laboratory, Oak Ridge, Tennessee.

PNL-6584, 1988, GENII-The Hanford Environmental Radiation Dosimetry Software System, Volume 1, Pacific Northwest Laboratory, Richland, Washington.

Schwartz, R. A., 1996, Error in Cm-244 Concentration Calculated by ORIGEN2, (DSI to J. C. Van Keuren, May 1),Westinghouse Hanford Company, Richland, Washington.

TWRS-RT-SER-003, 1999, Safety Evaluation Report for the Tank Waste Remediation System (TWRS) Final Safety Analysis Report (FSAR) [HNF-SD-WM-SAR-067, Rev. H, September 1998] and Technical Safety Requirements [HNF-SD-WM-TSR-006, Rev. F2, August 1997], Rev. 0, U.S. Department of Energy, Richland Operations Office, Richland, Washington.

WHC-SD-WM-ER-400, 1995, Tank Waste Source Term Inventory Validation, Rev. 0, Volumes I and II, Westinghouse Hanford Company, Richland, Washington.

WHC-SD-WM-RPT-164, 1995, Inventories for Low Level Waste Tank Waste, Rev. 0, Westinghouse Hanford Company, Richland, Washington.

WHC-SD-WM-SARR-016, 1996, Tank Waste Compositions and Atmospheric Dispersion Coefficients for Use in Safety Analysis Consequence Assessments, Rev. 2, Westinghouse Hanford Company, Richland, Washington. 
RPP-5924 REV 0

APPENDIX C

SAMPLE BASED UNIT LITER DOSE ESTIMATES

C-1 


\section{RPP-5924 REV 0}

This page intentionally left blank. 
HNF-4534

Revision 1

\section{SAMPLE BASED UNIT LITER DOSE ESTIMATES}

L. Jensen

S. R. Wilmarth

CH2M HILL Hanford Group, Inc.

Date Published

April $\mathbf{2 0 0 0}$

Prepared for the U.S. Department of Energy

Office of River Protection

Approved for public release; distribution is unlimited 
RPP-5924 REV 0

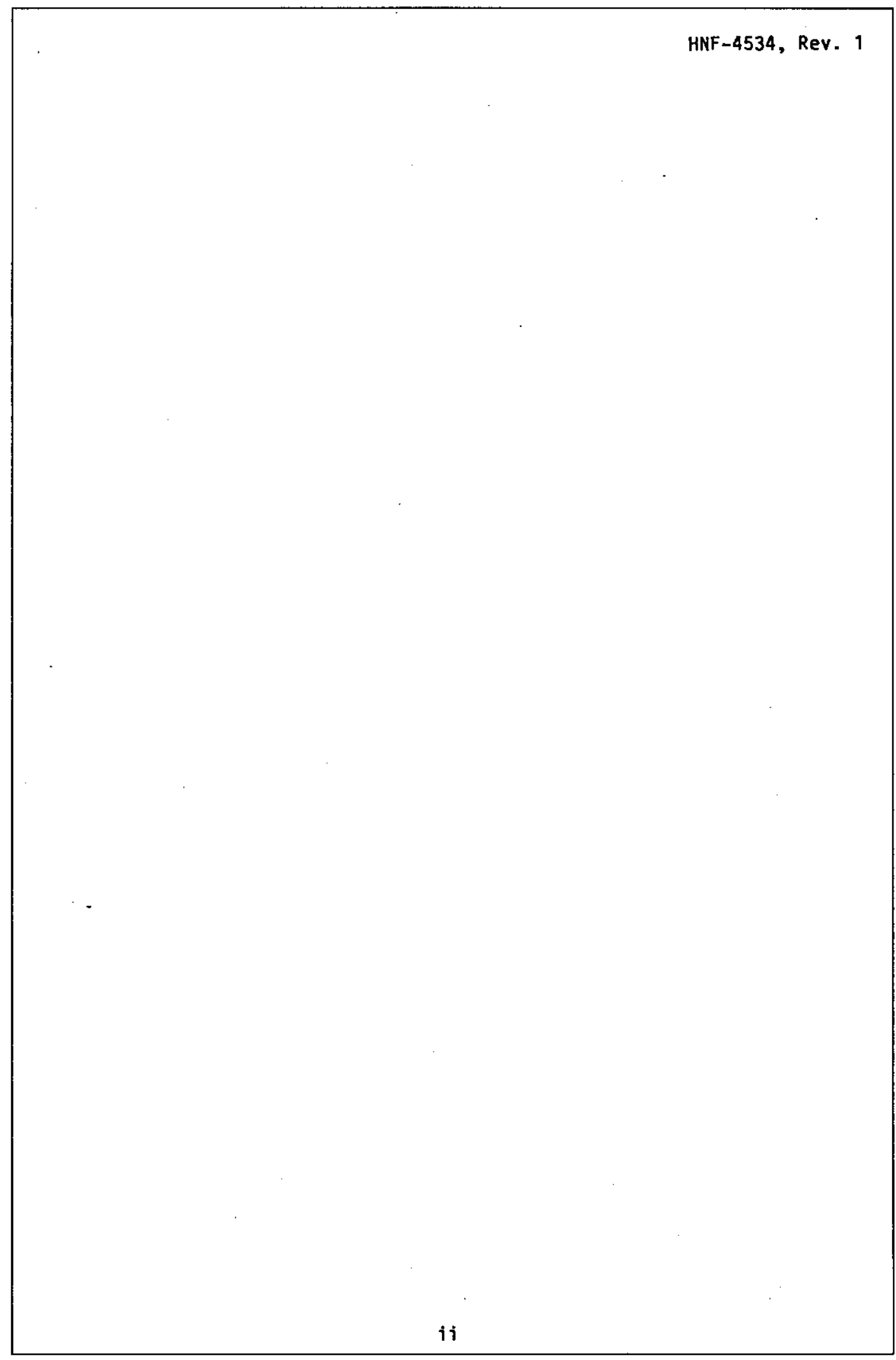

C-4 


\section{HNF-4534 Rev. 1}

\section{CONTENTS}

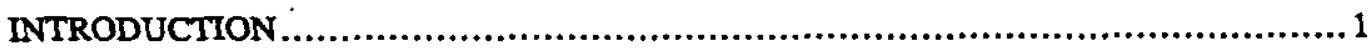

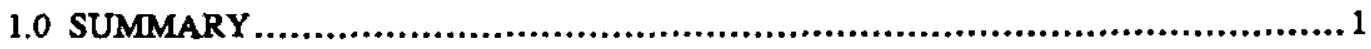

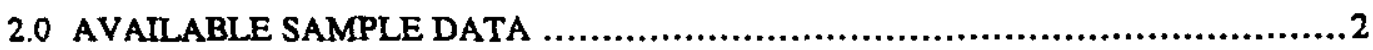

2.1 TANK SPECIFIC RADIOISOTOPE CONCENTRATIONS ............................................

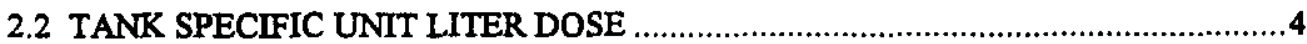

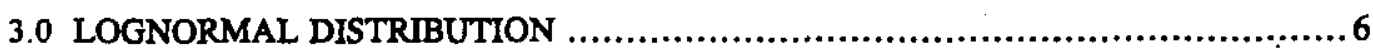

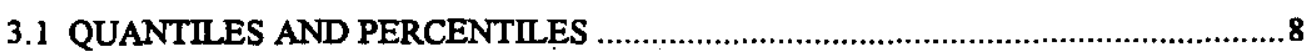

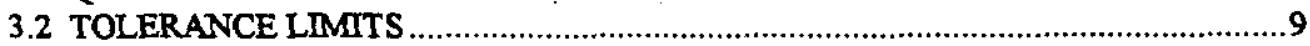

4.0 VALIDITY OF ASSUMPTIONS..................................................... 11

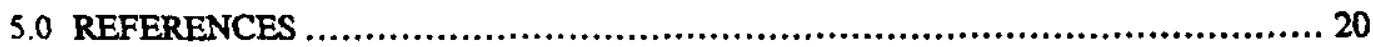

\section{APPENDICES}

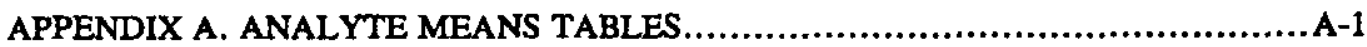

APPENDIX B. UNIT LITER DOSE TABLES .....................................................1

APPENDIX C. COMPARISON OF ANALYTE AND ULD MEANS AND VARIANCES C-1 APPENDIX D. S-PLUS FUNCTIONS FOR COMPUTING THE ULD .................... D-1 APPENDIX E. INDEPENDENT REVIEW ....................................... E-1 
RPP-5924 REV 0

HNF-4534 Rev. 1

\section{LIST OF FIGURES}

Figure 1. ULD Lognormal Density and Histogram, Single-Shell Tank Solid Waste,

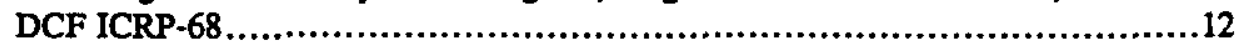

Figure 2. ULD Lognormal Density and Histogram, Single-Shell Tank Liquid Waste, DCF ICRP-68.

Figure 3. ULD Lognormal Density and Histogram, Double-Shell Tank Solid Waste, DCF ICRP-68.

Figure 4. ULD Lognormal Density and Histogram, Double-Shell Tank Liquid Waste, DCF ICRP-68 .....................................................................13

Figure 5. ULD Lognormal Density and Histogram, Single-Shell Tank Solid Waste, DCF ICRP-71 .14

Figure 6. ULD Lognormal Density and Histogram, Singie-Shell Tank Liquid Waste, DCF ICRP-71

Figure 7. ULD Lognormal Density and Histogram, Double-Shell Tank Solid Waste, DCF ICRP-71

Figure 8. ULD Lognormal Density and Histogram, Double-Shell Tank Liquid Waste, DCF ICRP-71. .15

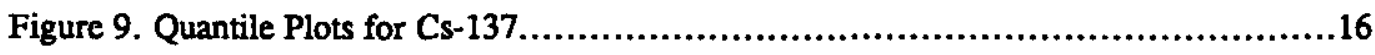

Figure 10. Quantile Plots for Alpha ...................................................17

Figure 11. Quantile Plots for Sr-90 ....................................................18

iv 


\section{HNF-4534 Rev. 1}

\section{LIST OF TABLES}

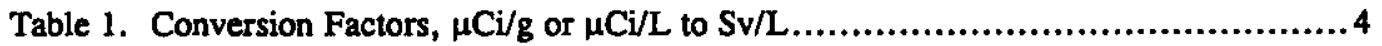

Table 2. Estimates of Means and Variances for the Lognormal Distribution ................... 7

Table 3. Quantiles Corresponding to the $95^{\text {th }}$ and $99^{*}$ Percentiles of the Lognormal Distribution based on ULD.M1 and the FSAR ULD

Table 4. Values of $\mathbf{X}$ for One-sided $95 \%$ Tolerance Limits

Table 5. One-Sided $95 \%$ Tolerance Limits for the Proportion $P=0.95$ and $P=0.99$ Based on the Lognormal Distribution for ULD.M1 and the FSAR ULD.

Table A-1. Mean ${ }^{137} \mathrm{Cs}$ Concentration $(\mu \mathrm{Ci} / \mathrm{g})$, SST Solid Samples

Table A-2. Mean Alpha Concentration ( $\mu \mathrm{Ci} / \mathrm{g})$, SST Solid Samples.

Table A-3. Mean ${ }^{2980} \mathrm{Sr}$ Concentration $(\mu \mathrm{Ci} / \mathrm{g})$, SST Solid Samples

Table A-4. Mean ${ }^{137} \mathrm{Cs}$ Concentration $(\mu \mathrm{Ci} / \mathrm{g})$, SST Liquid Samples.

Table A-5. Mean Alpha Concentration ( $\mu \mathrm{Ci} / \mathrm{g})$, SST Liquid Samples.

Table A-6. Mean ${ }^{8990} \mathrm{Sr}$ Concentration $(\mu \mathrm{Ci} / \mathrm{g})$, SST Liquid Samples

Table A-7. Mean ${ }^{137} \mathrm{Cs}$ Concentration ( $\mu \mathrm{Ci} / \mathrm{g}$ ), DST Solid Samples.

Table A-8. Mean Alpha Concentration ( $\mu \mathrm{Ci} / \mathrm{g})$, DST Solid Samples

Table A-9. Mean ${ }^{8990} \mathrm{Sr}$ Concentration $(\mu \mathrm{Ci} / \mathrm{g})$, DST Solid Samples.

Table A-10. Mean ${ }^{137} \mathrm{Cs}$ Concentration $(\mu \mathrm{Ci} / \mathrm{L})$, DST Liquid Samples A-15

Table A-11. Mean Alpha Concentration $(\mu \mathrm{Ci} / \mathrm{L})$, DST Liquid Samples.

Table A-12. Mean ${ }^{89 / 90} \mathrm{Sr}$ Concentration $(\mu \mathrm{Ci} / \mathrm{L})$, DST Liquid Samples

Table A-13. Data from Tanks 241-AZ-101 and 241-AZ-102

Table B-1. ULD SST Solid Samples (Sv/L)

Table B-2. ULD SST Liquid Samples (Sv/L)

Table B-3. ULD DST Solid Samples (Sv/L) 


\section{HNF-4534 Rev. 1}

Table B-4. ULD DST Liquid Samples (Sv/L) B-5

Table C-1. Comparison of Means $(\mu \mathrm{Ci} / \mathrm{g})$ and Variances $\left(\mu \mathrm{Ci} / \mathrm{g}^{2}\right)$ by Radionuclide and Waste Type for the Three Models ( M1, M2, and M3) for Detection Limits C-2

Table C-2. Comparison of Means (Sv/L) and Variances (Sv/L ${ }^{2}$ ) of ULDs by Waste Type for the Three Models (M1, M2, and M3) for Detection Limits .....................C-4

Table C-3. Quantiles (Sv/L) Corresponding to the $95^{\star}$ and $99^{\star}$ Percentiles Points and 95/59 and 95/99 Tolerance Limits (Sv/L) for the Lognormal Distribution for the Three Models for Below Detection Limit Observations

\section{LIST OF TERMS}

\begin{tabular}{|c|c|}
\hline $\mathrm{Bq} / \mu \mathrm{Ci}$ & Becquerel per microcurie \\
\hline BIO & Basis for Interim Operation \\
\hline DL & detection limit \\
\hline DCF & dose conversion factor \\
\hline DST & double-shell tank \\
\hline FDH & Fluor Daniel Hanford, Inc. \\
\hline FSAR & Final Safety Analysis Report \\
\hline GA & Gross alpha \\
\hline$g / L$ & grams per liter \\
\hline Num.Above DL & number of observations above detection limit \\
\hline Num.Obs & number of observations \\
\hline $\begin{array}{l}\text { NS\&L } \\
\text { TL }\end{array}$ & $\begin{array}{l}\text { Nuclear Safety and Licensing } \\
\text { tolerance limit }\end{array}$ \\
\hline$\mu \mathrm{Ci} / \mathrm{g}$ & microcuries per gram \\
\hline$\mu \mathrm{Ci} / \mathrm{L}$ & microcuries per liter \\
\hline $\begin{array}{l}\mu g / L \\
\%\end{array}$ & $\begin{array}{l}\text { micrograms per liter } \\
\text { percent }\end{array}$ \\
\hline SST & single-shell tank \\
\hline $\mathrm{Sv} / \mathrm{Bq}$ & sieverts per Becquerel \\
\hline $\mathrm{Sv} / \mathrm{L}$ & sieverts per liter \\
\hline TCD & Tank Characterization Database \\
\hline ULD & unit liter dose \\
\hline WHC & Westinghouse Hanford Company \\
\hline
\end{tabular}

vi 


\section{HNF-4534 Rev. 1}

\section{INTRODUCTION}

The Tank Waste Characterization Program has taken many core samples, gräb samples, and auger samples from the single-shell and double-shell tanks during the past 10 years. Consequently, the amount of sample data available has increased, both in terms of quantity of sample results and the number of tanks characterized. More and better data is available than when the current radiological and toxicological source terms used in the Basis for Interim Operation (BIO) (FDH 1999a) and the Final Safety Analysis Report (FSAR) (FDH 1999b) were developed.

The Nuclear Safety and Licensing (NS\&L) organization wants to use the new data to upgrade the radiological and toxicological source terms used in the BIO and FSAR. The NS\&L organization requested assistance in producing a statistically based process for developing the source terms. This report describes the statistical techniques used and the assumptions made to support the development of a new radiological source term for liquid and solid wastes stored in single-shell and double-shell tanks.

The results given in this report are a revision to similar results given in an earlier version of the document (Jensen and Wilmarth 1999). The main difference between the results in this document and the earlier version is that the dose conversion factors (DCF) for converting $\mu \mathrm{Ci} / \mathrm{g}$ or $\mu \mathrm{Ci} / \mathrm{L}$ to $\mathrm{Sv} / \mathrm{L}$ (sieverts per liter) have changed. There are now two DCFs, one based on ICRP-68 and one based on ICRP-71 (Brevick 2000).

\subsection{SUMMARY}

Estimates of unit liter doses (ULDs) for waste in the single-shell tanks (SSTs) and double-shell tanks (DSTs) were computed based on recent sampling data from the tanks. The units for a ULD are sieverts per liter (Sv/L). The data was obtained from the Tank Characterization Database. There was sufficient data to estimate a ULD for 54 (57) SSTs with solid samples, 23 (26) SSTs with liquid samples, 15 (15) DSTs with solid samples, and 26 (27) DSTs with liquid samples. The numbers in parentheses refer to the number of tanks with a ULD if observations below detection limits are included.

If it is assumed that the tanks selected for characterization were selected at random, then the ULDs given in this document are unbiased estimates of the ULDs for all SSTs and DSTs. However, it may not be appropriate to assume that the characterized tanks were chosen at random. Many of the tanks that were selected were chosen because they were known to contain wastes that were of concern to Hanford's unresolved safety questions and safety issues. Consequently, if the data from the characterized tanks are an upper bound for all of the tanks then the ULDs are also an upper bound for all tanks. 
HNF-4534 Rev. 1

The lognormal probability distribution was fit to the ULDs. ULD quantiles (Sv/L) corresponding to the $95^{\mathrm{t}}$ and $99^{*}$ percentiles of the lognormal distribution were computed. The ULDs (Sv/L) corresponding to the $95 / 95$ and 95/99 tolerance limits (TLs) were also computed (the interpretation of the TLs are, we are $95 \%$ confident that at least $95 \%$ (99\%) of the population is less than the limit). The ULD quantiles and TLs are compared to the ULDs for the FSAR (FDH 1999b). In all but one cases, the ULD for the FSAR is greater than the $95^{\star}$ and $99^{\circ}$ percentiles of the lognormal distribution. The exception is that the FSAR is less than the $99^{\circ}$ for DST solid samples based on DCF ICRP-71. The FSAR is greater than the 95/95 TL except for ULDs based on DST liquid samples. They are less than the 95/99 TL except for ULDs based on SST solid samples.

\subsection{AVAILABLE SAMPLE DATA}

The TCD (Tank Characterization Database) contains the waste characterization data from tank samples obtained since 1989. This database was the source of data used to estimate the ULD for each waste storage tank.

From TCD, all of the data (available in January 2000) for the following five isotopes were obtained, ${ }^{137} \mathrm{Cs}$, gross alpha, ${ }^{241} \mathrm{Am},{ }^{89190} \mathrm{Sr}$, and ${ }^{90} \mathrm{Sr}$. There were a total of 12,603 observations. There were 3,475 observations from liquid samples and 9,128 from solid samples. There were 141 observations on liquid samples with inconsistent units; e.g., 137 observations from liquid samples with units $\mu \mathrm{Ci} / \mathrm{g}, 3$ with unit's $\mu \mathrm{g} / \mathrm{L}$, and one observation with no units. There were 115 observations with the " $R$ " qualifier. The " $R$ " denotes that the observation is unusable. All observations with the " $R$ " qualifier and inconsistent units were deleted. The remaining 12,380 observations consisted of 3,357 on liquid samples and 9,023 on solid samples. There were 998 observations on liquid samples that were below the detection limits and 1,780 observation on solid samples below detection limits. The units are $\mu \mathrm{Ci} / \mathrm{g}$ or $\mu \mathrm{Ci} / \mathrm{L}$. Not every tank had data from each of the five isotopes.

Estimates of the ULD were computed based on three methods for incorporating observations that were below detection limits. First, all observations below detection limits were deleted. In this case, the quantile estimates in the tables and figures apply to the proportion of the population with analyte concentrations above detection limits. Figures 1 through 8 , which summarize the computations, are based on this method. Second, the below detection limit observations were replaced by the detection limit, and third, the below detection limit observations were replaced by zero. Note that these three methods each introduce a bias into the final results. A statistical comparison of the results given by each method indicates that the differences are small.

The ULDs were computed based only on the isotopes ${ }^{237} \mathrm{Cs}$ and ${ }^{90} \mathrm{Sr}$ and on alpha. The validity of this assumption is outlined in Sections 2.0 and 3.0 of Jensen et al. (1998) and in Table 3 of WHC-SD-WM-SARR-037 (WHC 1996). 
HNF-4534 Rev. 1

\subsection{TANK SPECIFIC RADIOISOTOPE CONCENTRATIONS}

For each tank, the arithmetic mean $(\mu \mathrm{Ci} / \mathrm{g}$ or $\mu \mathrm{Ci} / \mathrm{L})$ of the data for each of the five isotopes was computed. The data from the different analytical procedures were combined. That is, the data from the water, the acid and the fusion dissolution were combined.

The following methods were used to select the data used in the ULD calculations.

Eor ${ }^{137} \mathrm{Cs}:$ The mean of the ${ }^{137} \mathrm{Cs}$ data was used.

For alpha: If available, the mean for gross alpha was used. If there was no mean for gross alpha, the mean from ${ }^{241} \mathrm{Am}$ was used.

For ${ }^{90} \mathrm{~S}$ : If available, the mean for ${ }^{8900} \mathrm{Sr}$ was used. If there was no mean for ${ }^{19190} \mathrm{Sr}$, the mean for ${ }^{90} \mathrm{Sr}$ was used. If there was a mean for both ${ }^{8990} \mathrm{Sr}$ and ${ }^{90} \mathrm{Sr}$, the mean of the combined data was used.

Tables A-1 to A-12 in Appendix A list the means for ${ }^{137} \mathrm{Cs}$, for GA (gross alpha), and for ${ }^{90} \mathrm{Sr}$. The tables are given by type of tank, SST and DST, and by type of waste, solid and liquid. The values in Table A-1 to A-12 are slightly different from the corresponding tables given in Rev. 0 of this document (Jensen and Wilmarth 1999). The reasons for the difference are that additional tank sample data has been added to TCD and that in Rev. 0 , observations on total alpha (total alpha energy emitted from ${ }^{285} \mathrm{Pu},{ }^{239} \mathrm{Pu},{ }^{210} \mathrm{Pu}$ and ${ }^{211} \mathrm{Pu}$ ) were combined with gross alpha. The observations on total alpha were not included in the results reported here. However, for most tanks, the means reported in Appendix A of this document and in Appendix A of Rev. 0 are identical. The tables in Appendix A also list the number of observations available by analyte and the number of observations above the detection limit (DL).

There are a total of 149 SSTs and 28 DSTs, and the ULDs can only be estimated for a subset of the total number of tanks. The estimates of the ULDs given in this document are unbiased estimates of the ULDs for all SSTs and DSTs if it is assumed that the tanks with a mean for ${ }^{137} \mathrm{Cs}$, for alpha, and for ${ }^{90} \mathrm{Sr}$ (Tables A-1 through A-12) are a random sample of the tanks. Alternatively, if it is assumed that the tanks with a mean for ${ }^{137} \mathrm{Cs}$, for alpha, and for ${ }^{90} \mathrm{Sr}$ are an upper bound to the means for all of the other tanks, then the ULDs based on the sampled tanks are an upper bound for the ULDs for all tanks.

There was insufficient data from TCD to compute a ULD for the two aging waste tanks 241AZ-101 and 241-AZ-102. However, some preliminary laboratory data was available from recent tank samples. Table A-13 lists the summary means obtained from the TCD and the preliminary samples. For tank 241-AZ-101, a ULD could not be computed based on solid samples. For liquid samples, a ULD was computed using the laboratory detection limit (DL) for gross alpha as a quantitative value. 
HNF-4534 Rev. 1

\subsection{TANK SPECIFIC UNIT LITER DOSE}

The units of the means in Tables $A-1$ to $A-12$ are $\mu \mathrm{Ci} / \mathrm{g}$ or $\mu \mathrm{Ci} / \mathrm{L}$. The units for the ULD are Sv/L. The conversions factors used are given in Table 1. The fourth and sixth rows of this table are the dose conversion factors (DCF) for ${ }^{137} \mathrm{Cs}$, alpha, and ${ }^{90} \mathrm{Sr}$. There are two DCFs, the first is DCF based on ICRP-68 5 $\mu \mathrm{m}$ AMAD (DCF ICRP-68) and the second is the DCF based on ICRP-71 adult (DCF ICRP-71). It is assumed that the concentration for ${ }^{90} \mathrm{Y}$ is the same as that for ${ }^{90} \mathrm{Sr}$.

The dose conversion factors (DCF) given in Table 1 are different from the conversion factors used in Rev. 0 of this document (Jensen and Wilmarth 1999).

Table 1. Conversion Factors, $\mu \mathrm{Ci} / \mathrm{g}$ or $\mu \mathrm{Ci} / \mathrm{L}$ to $\mathrm{Sv} / \mathrm{L}$

\begin{tabular}{|c|c|c|c|c|}
\hline Units & ${ }^{i n} \mathrm{C}_{5}$ & Alphaz & 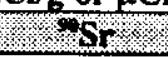 & . \\
\hline $\mathrm{Bg} / \mu \mathrm{Ci}$ & $3.70 \mathrm{E}+04$ & & $3.70 \mathrm{E}+$ & $3.70 \mathrm{E}+04$ \\
\hline $\mathrm{g} / \mathrm{L}^{3}$ & $1.60 \mathrm{E}$ & & $1.60 \mathrm{E}+03$ & +03 \\
\hline \multicolumn{5}{|c|}{ DEFICRP 68 D } \\
\hline $\mathrm{Sv} / \mathrm{Bq}^{\mathrm{i}}$ & $6.70 \mathrm{E}-09$ & $2.89 \mathrm{E}-05$ & $3.00 \mathrm{E}-08$ & $1.70 \mathrm{E}-09$ \\
\hline \multicolumn{5}{|c|}{ BOR TCRP II } \\
\hline $\mathrm{v} / \mathrm{Bq}^{1}$ & $4.60 \mathrm{E}-09$ & & & $1.50 \mathrm{E}-09$ \\
\hline
\end{tabular}

${ }^{1}$ The DCF for Sv/Bq are reported in the Attachment to (Brevick 2000).

${ }^{3}$ The DCF for alpha is the mean of four values: SST liquid and solid and DST liquid and solid. ${ }^{3}$ The conversion $\mathrm{g} / \mathrm{L}$ from a weight basis to a liquid basis is given on page 7 of Brevick et al. (1996).

From Table 1, the conversion from $\mu \mathrm{Ci} / \mathrm{g}$ to $\mathrm{Sv} / \mathrm{L}$ for solid samples is

$$
\mathrm{Sv} / \mathrm{L}=(\mu \mathrm{Ci} / \mathrm{g}) \times(\mathrm{Bq} / \mu \mathrm{Ci}) \times(\mathrm{g} / \mathrm{L}) \times(\mathrm{Sv} / \mathrm{Bq}),
$$

and for liquid sample the conversion from $\mu \mathrm{Ci} / \mathrm{L}$ to $\mathrm{Sv} / \mathrm{L}$ is

$$
\mathrm{Sv} / \mathrm{L}=(\mu \mathrm{Ci} / \mathrm{L}) \times(\mathrm{Bq} / \mu \mathrm{Ci}) \times(\mathrm{Sv} / \mathrm{Bq})
$$

Using the DCF ICRP-68, for solid samples, the equations used to convert $\mu \mathrm{Ci} / \mathrm{g}$ to $\mathrm{Sv} / \mathrm{L}$ are

$$
\begin{aligned}
& \mathrm{Sv} / \mathrm{L}\left({ }^{137} \mathrm{Cs}\right)=\operatorname{mean}\left({ }^{37} \mathrm{Cs}\right) \times(3.70 \mathrm{E}+04) \times(1.60 \mathrm{E}+03) \times(6.70 \mathrm{E}-09) \\
& \mathrm{Sv} / \mathrm{L}(\text { alpha })=\text { mean }(\text { alpha }) \times(3.70 \mathrm{E}+04) \times(1.60 \mathrm{E}+03) \times(2.89 \mathrm{E}-05) \\
& \mathrm{Sv} / \mathrm{L}\left({ }^{90} \mathrm{Sr}+{ }^{90} \mathrm{Y}\right)=\operatorname{mean}\left({ }^{00} \mathrm{Sr}\right) \times(3.70 \mathrm{E}+04) \times(1.60 \mathrm{E}+03) \times(3.00 \mathrm{E}-08+1.70 \mathrm{E}-09) .
\end{aligned}
$$

For liquid samples, the equations used to convert $\mu \mathrm{Ci} / \mathrm{L}$ to $\mathrm{Sv} / \mathrm{L}$ are 


\section{RPP-5924 REV 0}

\section{HNF-4534 Rev. 1}

$\mathrm{Sv} / \mathrm{L}\left({ }^{137} \mathrm{Cs}\right)=\operatorname{mean}\left({ }^{137} \mathrm{Cs}\right) \times(3.70 \mathrm{E}+04) \times(6.70 \mathrm{E}-09)$

Sv/L (alpha $)=$ mean $($ alpha $) \times(3.70 \mathrm{E}+04) \times(2.89 \mathrm{E}-05)$

$\mathrm{Sv} / \mathrm{L}\left({ }^{10} \mathrm{Sr}+{ }^{90} \mathrm{Y}\right)=\operatorname{mean}\left({ }^{\circ 0} \mathrm{Sr}\right) \times(3.70 \mathrm{E}+04) \times(3.00 \mathrm{E}-08+1.70 \mathrm{E}-09)$ 
HNF-4534 Rev. 1

Using the DCF ICRP-71, for solid samples, the equations used to convert $\mu \mathrm{Ci} / \mathrm{g}$ to $\mathrm{Sv} / \mathrm{L}$ are

$$
\begin{aligned}
& \mathrm{Sv} / \mathrm{L}\left({ }^{137} \mathrm{Cs}\right)=\operatorname{mean}\left({ }^{137} \mathrm{Cs}\right) \times(3.70 \mathrm{E}+04) \times(1.60 \mathrm{E}+03) \times(4.60 \mathrm{E}-09) \\
& \mathrm{Sv} / \mathrm{L}(\text { alpha })=\text { mean }(\text { alpha }) \times(3.70 \mathrm{E}+04) \times(1.60 \mathrm{E}+03) \times(4.50 \mathrm{E}-05) \\
& \mathrm{Sv} / \mathrm{L}\left({ }^{00} \mathrm{Sr}+{ }^{00} \mathrm{Y}\right)=\operatorname{mean}\left({ }^{00} \mathrm{Sr}\right) \times(3.70 \mathrm{E}+04) \times(1.60 \mathrm{E}+03) \times(3.60 \mathrm{E}-08+1.50 \mathrm{E}-09) .
\end{aligned}
$$

For liquid samples, the equations used to convert $\mu \mathrm{Ci} / \mathrm{L}$ to $\mathrm{Sv} / \mathrm{L}$ are

$$
\begin{aligned}
& \mathrm{Sv} / \mathrm{L}\left({ }^{137} \mathrm{Cs}\right)=\text { mean }\left({ }^{137} \mathrm{Cs}\right) \times(3.70 \mathrm{E}+04) \times(4.60 \mathrm{E}-09) \\
& \mathrm{Sv} / \mathrm{L}(\text { alpha })=\text { mean }(\text { alpha }) \times(3.70 \mathrm{E}+04) \times(4.50 \mathrm{E}-05) \\
& \mathrm{Sv} / \mathrm{L}\left({ }^{90} \mathrm{Sr}+{ }^{90} \mathrm{Y}\right)=\text { mean }\left({ }^{10} \mathrm{Sr}\right) \times(3.70 \mathrm{E}+04) \times(3.60 \mathrm{E}-08+1.50 \mathrm{E}-09)
\end{aligned}
$$

The ULD is defined to be the sum of the Sv/L for the four isotopes. The ULDs, for each tank and waste type, are given in Tables B-1, B-2, B-3, and B-4 in Appendix B. ULDs, for tanks 241-AY-101 and 241-AY-102, are included in Tables B-3 and B-4. These two tanks are "aging waste tanks." Tanks 241-AZ-101 and 241-AZ-102 are also "aging waste tanks." The ULDs for these two tanks were computed using the data in Table A-13.

All of the statistical computations were performed using the computer program S-PLUS (S-PLUS 2000). The S-PLUS functions written to convert $\mu \mathrm{Ci} / \mathrm{g}$ or $\mu \mathrm{Ci} / \mathrm{L}$ to $\mathrm{Sv} / \mathrm{L}$ and to form the ULD are listed in Appendix D.

\subsection{LOGNORMAL DISTRIBUTION}

Three probability distributions can be fit to the ULD data: a lognormal, a gamma, and a Weibull. A goodness-of-fit test was used to test the appropriateness of the three distributions. Based on the goodness-of-fit test, the lognormal distribution cannot be rejected for SST solid samples and DST solid and liquid samples. At the 0.05 level of significance, the lognormal distribution is rejected for SST liquid samples. The gamma and Weibull distributions are also marginal for SST liquid samples.

These three distributions were also fit to ULDs used in the gas release event safety analysis tool (Jensen et al. 1998). For that project, and for Rev. 0 of this document (Jensen and Wilmarth 1999), the lognormal distribution was the recommended distribution. In addition, tolerance limits can be computed for the lognormal distribution, but not for the gamma or Weibull distribution (tolerance limits are discussed in Section 3.2). To be consistent with Jensen et al. (1998) and since the lognormal distribution cannot be totally rejected, a lognormal 


\section{HNF-4534 Rev. 1}

distribution is the recommended distribution for the ULDs. Even though the lognormal distribution for the SST liquid samples was rejected, the statistical results will be based on the lognormal distribution. Consequently, they should be used with caution.

The lognormal distribution is defined as follows. A random variable $\mathrm{X}$ has a lognormal distribution if $Y=\log (X)$ has a normal distribution. The lognormal density function has the form

$$
\begin{aligned}
f(x)=\frac{1}{x \sqrt{2 \pi} \sigma} & \exp \left\{-\frac{(\log (x)-\mu)^{2}}{2 \sigma^{2}}\right\}, x>0 \\
& =0, x \leq 0
\end{aligned}
$$

where $\mu$ is the mean of $Y=\log (X)$ and $\sigma^{2}$ is the variance of $Y=\log (X)$. The unbiased estimates of $\mu$ and $\sigma^{2}$ are the sample mean, $\hat{\mu}$, and sample variance, $\hat{\sigma}^{2}$, on the natural $\log$ scale. Table 2 gives the estimates of the means and variances for the four types of samples. The individual ULDs are given in Tables B-1 through B-8. The terms M1, M2, and M3 refer to the three models for using observations below detection limits; that is, they refer to deleting all observations below the detection limit, replacing the observations by the detection limit, and replacing them with zero. As can be seen from Table 2, there is little change in the estimates $\hat{\mu}$ and $\hat{\sigma}^{2}$ between the three models. This means that there is little difference in the lognormal distributions for the three sets of ULDs.

Table 2. Estimates of Means $(\log (\mathrm{Sv} / \mathrm{L}))$ and Variances $\left((\log (\mathrm{Sv} / \mathrm{L}))^{2}\right)$ for the Lognormal

\begin{tabular}{|c|c|c|c|c|c|c|}
\hline \multirow{2}{*}{$\begin{array}{l}\text { DCF } \\
\text { ICRP-68 }\end{array}$} & ULD $\mathbf{M 1}$ & 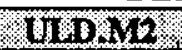 & THD MB & UUDXM. & WIOOMON & TUDMB \\
\hline & \multicolumn{3}{|c|}{ SST Solid Samples } & \multicolumn{3}{|c|}{ SST Yuqua Sanples } \\
\hline Num, Mamis & 54 & 57 & 57 & 23 & 26 & 26 \\
\hline$\hat{\mu}$ & $6.55 \mathrm{E}+00$ & $6.49 \mathrm{E}+00$ & $6.42 \mathrm{E}+00$ & $4.26 \mathrm{E}+00$ & $4.34 \mathrm{E}+00$ & $4.12 \mathrm{E}+00$ \\
\hline \multirow[t]{2}{*}{$\dot{\sigma}^{2}$} & $2.72 \mathrm{E}+00$ & $2.62 \mathrm{E}+00$ & $2.79 \mathrm{E}+00$ & $3.35 \mathrm{E}+00$ & $3.17 \mathrm{E}+\infty 0$ & $2.89 \mathrm{E}+00$ \\
\hline & \multicolumn{3}{|c|}{ DST Solid Samples: } & \multicolumn{3}{|c|}{ DST LIquid Samples } \\
\hline Num. Taniks & 15 & 15 & 15 & 26 & 27 & 27 \\
\hline$\hat{\mu}$ & $7.81 \mathrm{E}+00$ & $7.77 \mathrm{E}+00$ & $7.72 \mathrm{E}+00$ & $3.90 \mathrm{E}+00$ & $3.81 \mathrm{E}+00$ & $3.72 \mathrm{E}+00$ \\
\hline$\hat{\sigma}^{2}$ & $5.24 \mathrm{E}+00$ & $5.34 \mathrm{E}+00$ & $5.57 \mathrm{E}+00$ & $2.86 \mathrm{E}+00$ & $2.92 \mathrm{E}+00$ & $2.99 \mathrm{E}+00$ \\
\hline \multirow{2}{*}{$\begin{array}{l}\mathrm{DCF} \\
\mathrm{ICRP} / \mathrm{T}\end{array}$} & & ULDN2 & (B1\% & YUD WI & U⿴囗十丁: & WMDME \\
\hline & \multicolumn{3}{|c|}{ SSTSOlit Samples } & \multicolumn{3}{|c|}{ SST Gould Samples } \\
\hline Nim. Tanks & 54 & 57 & 57 & 23 & 26 & 26 \\
\hline$\hat{\mu}$ & $6.86 \mathrm{E}+00$ & $6.80 \mathrm{E}+\infty$ & $6.71 \mathrm{E}+00$ & $4.15 \mathrm{E}+00$ & $4.26 \mathrm{E}+00$ & $3.93 \mathrm{E}+00$ \\
\hline$\hat{\sigma}^{2}$ & $2.82 \mathrm{E}+00$ & $2.72 \mathrm{E}+00$ & $2.96 \mathrm{E}+00$ & $3.13 \mathrm{E}+00$ & $3.06 \mathrm{E}+00$ & $2.62 \mathrm{E}+00$ \\
\hline
\end{tabular}
Distribution (2 sheets) 
HNF-4534 Rev. 1

Table 2. Estimates of Means $(\log (S v / L))$ and Variances $\left((\log (S v / L))^{2}\right)$ for the Lognormal Distribution (2 sheets)

\begin{tabular}{|c|c|c|c|c|c|c|}
\hline & U1G & Urk $\mathrm{B}, \mathrm{M}^{2}$ & UI D.MB & UI D.MT & ruo & ULD \\
\hline ICRP 71 & \multicolumn{3}{|c|}{ DST Solid Samples } & \multicolumn{3}{|c|}{ DST Trquad Sranples } \\
\hline Nim, Tanks & 15 & 15 & 15 & 26 & 27 & 27 \\
\hline$\hat{\mu}$ & $8.09 \mathrm{E}+00$ & $8.04 \mathrm{E}+00$ & $7.96 \mathrm{E}+00$ & $3.79 \mathrm{E}+00$ & $3.69 \mathrm{E}+00$ & $3.54 \mathrm{E}+\infty 0$ \\
\hline$\hat{\sigma}^{2}$ & $5.71 E+00$ & $5.86 \mathrm{E}+00$ & $6.25 \mathrm{E}+00$ & $3.03 \mathrm{E}+00$ & $3.10 \mathrm{E}+00$ & $3.17 \mathrm{E}+00$ \\
\hline
\end{tabular}

The Kolmogorov-Smirnov goodness-of-fit test was used to determine the appropriateness of the lognormal distribution. If the level of significance is chosen to be 0.05 , the lognormal distribution cannot be rejected for SST solid samples and DST solid and liquid samples.

The appropriateness of the lognormal distribution for SST liquid samples is questionable. However, for these samples, the gamma distribution is also questionable, and the Weibull distribution only fits marginally well. The gamma distribution is also rejected for the SST solid samples. The difficulty with fitting any probability distribution to the ULD SST liquid sample data is that it appears to be bimodal. For this waste type, based on DCF ICRP-68, most of the ULD values are around $100 \mathrm{~Sv} / \mathrm{L}$, and there are two extreme values around $1,000 \mathrm{~Sv} / \mathrm{L}$. Based on DCF ICRP-71, most of the ULD values are around $70 \mathrm{~Sv} / \mathrm{L}$, and there are two extreme values around $1,500 \mathrm{~Sv} / \mathrm{L}$. For the SST liquid sample, the statistical results will be based on the lognormal distribution. However, they should be used with caution.

Figures 1 through 8 are plots of the lognormal density functions for the four types of waste listed in Table 2 using ULD.M1. Figures 1 through 4 are based on DCF ICRP-68 and Figures 6 through 8 are based on DCF ICRP-71. These plots are for the case when observations below the detection limits are omitted. The plots for the other cases are similar. Superimposed on these plots are histograms of the corresponding ULDs.

A probability density function is non-negative and integrates to one. The lognormal density functions, Figures 1 through 8 , do not integrate to one. They have been normalized so that they can be viewed when superimposed on the histograms.

\subsection{QUANTILES AND PERCENTILES}

The ULDs in the FSAR (FDH 1999b), for the four types of waste, need to be compared to the quantiles (Sv/L) corresponding to the $95^{\star}$ and $99^{*}$ percentiles of the lognormal distributions based on ULD.M1. Table 3 lists these quantiles. The quantiles are the ULD.M1 values such that $95 \%$ or $99 \%$ of the "population" is to the left of the value. The quantiles are also given in Figures 1 through 8. Table 3 also lists the ULDs for the FSAR (FDH 1999b). Except for the $99^{\mathrm{t}}$ percentile for DST solid samples based on DCF ICRP-71, the FSAR ULD is greater than the quantile corresponding to the $95^{\text {th }}$ and the $99^{\text {th }}$ percentiles of the lognormal distribution for 


\section{HNF-4534 Rev. 1}

each of the four types of waste and DCFs. The $95^{\text {th }}$ and $99^{\text {th }}$ percentiles of the lognormal distribution using ULD.M2 and ULD.M3 are given in Table C-3 of Appendix C.

Table 3. Quantiles Corresponding to the $95^{\mathrm{th}}$ and $99^{\mathrm{k}}$ Percentiles of the Lognormal Distribution based on ULD.M1 and the FSAR ULD

\begin{tabular}{|c|c|c|c|c|}
\hline & \multicolumn{3}{|c|}{ Numbinks: $95^{\circ}, 99^{\circ}$} & \multirow{2}{*}{ RSWL } \\
\hline & \multicolumn{3}{|c|}{ DOTICRP $68(\mathrm{SvI})$} & \\
\hline SST Solid Samples & 54 & $1.06 \mathrm{E}+04$ & $3.26 \mathrm{E}+04$ & $2.20 \mathrm{E}+05$ \\
\hline SST Liquid Samples & 23 & $1.44 \mathrm{E}+03$ & $5.01 E+03$ & $1.10 \mathrm{E}+04$ \\
\hline DST Solid Samples & 15 & $1.07 \mathrm{E}$ & $5.09 \mathrm{E}+05$ & $0 \mathrm{E}+05$ \\
\hline \multirow[t]{2}{*}{ DST Liquid Samples } & 26 & $7.97 \mathrm{E}+02$ & $2.53 E+03$ & $6.10 \mathrm{E}+03$ \\
\hline & \multicolumn{3}{|c|}{ DCF ICRP -71 (SvII) } & \\
\hline SST So & 54 & $1.51 \mathrm{E}+04$ & $4.77 \mathrm{E}+04$ & $2.20 \mathrm{E}+05$ \\
\hline SST Lic & 23 & $1.16 \mathrm{E}+03$ & $3.88 \mathrm{E}+03$ & $1.10 \mathrm{E}+04$ \\
\hline DST So & 15 & $1.67 \mathrm{Et}$ & $8.53 \mathrm{E}+05$ & $5.30 \mathrm{E}+05$ \\
\hline DST Liquid Samples & 26 & $7.68 \mathrm{E}+02$ & $2.51 E+03$ & $6.10 \mathrm{E}+03$ \\
\hline
\end{tabular}

These quantiles should be used with caution. The reason is that the lognormal density functions are bases on estimates of the means and variances. These estimates are subject to variability, and this variability is not incorporated into the estimates of the quantiles. It is difficult to compute confidence statements for the quantiles and for the density functions. However, tolerance limits are similar to quantiles, and they incorporate the uncertainty due to using estimates of the means and variances. Tolerance limits may be more appropriate than the quantiles. They are discussed in the next section.

\subsection{TOLERANCE LIMITS}

A one-sided tolerance interval is a confidence statement regarding the proportion of the population below a given limit. The advantage of using TLs is that a confidence statement is part of the TL; i.e., measures of uncertainty are in a TL and they are not in the quantiles. These limits are based on the normal distribution. The limits are of the form $\hat{\mu}+K \hat{\sigma}$ where $\hat{\mu}$ and $\hat{\sigma}$ are the sample mean and standard deviation on the log scale. The values of $\mathrm{K}$ are tabulated (e.g., Tabie A-7 in Natrella 1963), they are a function of the number of observations, the confidence level, and the proportion. The value $\exp (\hat{\mu}+K \hat{\sigma})$ is the tolerance limit for the lognormal distribution.

The notation for a $95 \% \mathrm{TL}$ is $95 / \mathrm{P}$ were $\mathrm{P}$ is the proportion of the population. The interpretation of the tolerance interval is that we are $95 \%$ confident that at leasl $P \%$ of the population (distribution) is below the limit $\exp (\hat{\mu}+\mathrm{K} \hat{\sigma})$. Table 4 gives the values of $\mathrm{K}$ used to compute the 95/95 and 95/99 TLs. The TLs (Sv/L) and the ULD for the FSAR (FDH 1999b) 


\section{HNF-4534 Rev. 1}

are given in Table 5. Figures 1 through 8 also plot the TLs and the ULD for the FSAR (FDH 1999b) for the specific type of waste.

Table 4. Values of $\mathrm{K}^{1}$ for One-sided $95 \%$ Tolerance Limits

\begin{tabular}{|l|c|c|c|c|c|c|c|}
\hline Propopilon & 15 & 23 & 24 & $26^{2}$ & $27^{2}$ & $54^{2}$ & $57^{2}$ \\
\hline $\mathrm{P}=0.95$ & 2.566 & 2.329 & 2.309 & 2.278 & 2.263 & 2.048 & 2.035 \\
\hline $\mathrm{P}=0.99$ & 3.520 & 3.206 & 3.181 & 3.139 & 3.120 & 2.841 & 2.824 \\
\hline
\end{tabular}

${ }^{3}$ Natrella (1963), page T-15

${ }^{2}$ Estimated using lines interpolation

Table 5. One-Sided 95\% Tolerance Limits for the Proportion $P=0.95$ and $P=0.99$ Based on the Lognormal Distribution for ULD.M1 and the FSAR ULD

\begin{tabular}{|c|c|c|c|c|}
\hline \multirow{2}{*}{ (1) } & Num Sanks & $95195 \mathrm{VL}$ & $05199 \mathrm{WL}$ & $2 \times 85$ \\
\hline & \multicolumn{4}{|c|}{ DOD $10 \mathrm{RO} 68 \mathrm{~s} / \mathrm{m})$} \\
\hline SST Solid Samples & 54 & $2.06 \mathrm{E}+04$ & $7.63 E+04$ & 2.20E+05 \\
\hline SST Liquid Samples & 23 & $5.04 \mathrm{E}+03$ & $2.51 \mathrm{E}+04$ & $1.10 \mathrm{E}+04$ \\
\hline DST Solid Samples & 15 & $8.82 E+05$ & $7.84 \mathrm{E}+06$ & $5.30 \mathrm{E}+05$ \\
\hline DST Liquid Samples & 26 & $2.33 \mathrm{E}+03$ & $1.00 \mathrm{E}+04$ & $6.10 \mathrm{E}+03$ \\
\hline & (2., & \multicolumn{2}{|c|}{ 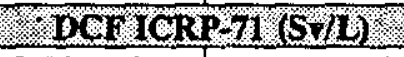 } & (7) \\
\hline SST Solid Samples & 54 & $2.99 \mathrm{E}+04$ & $1.14 \mathrm{E}+05$ & $2.20 \mathrm{E}+05$ \\
\hline SST Liquid Samples & 23 & $3.89 \mathrm{E}+03$ & $1.84 \mathrm{E}+04$ & $1.10 E+04$ \\
\hline DST Solid Samples & 15 & $1.51 \mathrm{E}+06$ & $1.49 \mathrm{E}+07$ & $5.30 \mathrm{E}+05$ \\
\hline DST Liquid Samples & 26 & $2.31 \mathrm{E}+03$ & $1.03 E+04$ & $6.10 \mathrm{E}+03$ \\
\hline
\end{tabular}

The FSAR ULD is greater than the 95/95 TL for all of the waste types except for DST solid samples. The FSAR ULD is less than the 95/99 TL except for the ULDs based on SST solid samples. The $95^{\text {th }}$ and $99^{\mathrm{t}}$ percentiles and the 95/95 TL and 95/99 TL using ULD.M2 and ULD.M3 are given in Table C-3 of Appendix C.

Figures 3, 4 and 7, 8 are the plots of the lognormal distributions for solid and liquid samples for DSTs including the aging waste tanks 241-AY-101, 241-AY-102, 241-AZ-101 (liquid samples) and 241-AZ-102. A ULD could not be estimated for solid samples from 241-AZ101. 
HNF-4534 Rev, 1

All of the statistical computations and figures were completed using the statistical program S-PLUS (S-PLUS 2000).

\subsection{VALIDITY OF ASSUMPTIONS}

To compute a ULD for a tank, there had to be sample data for each of ${ }^{137} \mathrm{Cs}$, alpha, and ${ }^{900} \mathrm{Sr}$. There were many tanks with sample data from at least one of ${ }^{137} \mathrm{Cs}$, alpha, or ${ }^{1010}{ }^{\mathrm{Sr}}$, but the data were not used to compute a ULD. In addition, three different models were used to incorporate observations below the detection limits. This section reports statistical results that compare ${ }^{137} \mathrm{Cs}$, alpha, and ${ }^{1090} \mathrm{Sr}$ tank means based on the available data and the subset of the data used to compute the ULD. There is also a statistical comparison of the ULDs computed from the three models.

Tables A-1 through A-12 in Appendix A list the means for ${ }^{137} \mathrm{Cs}$, alpha, and ${ }^{8900} \mathrm{Sr}$ for each of the four waste types, by tank and by the model for observations below the detection limits. Since all three of ${ }^{137} \mathrm{Cs}$, alpha, and ${ }^{50100} \mathrm{Sr}$ are needed to compute the ULD for a tank, only a subset of the data in these twelve tables was used to compute the four tables in Appendix B. For a given analyte and waste type, all of the available data can be compared to the subset used to compute the ULD by comparing means, comparing variances, and by comparing distributions.

The computer program S-PLUS (S-PLUS 2000) was used to make the comparicons. The SPLUS function t-test was used to compare the means, the function F-test was used to compare the variances, and the two-sample Kolmogorov-Smimov test function was used to compare the distributions. For the two-sample Kolmogorov-Smimov test, the distribution (e.g., normal, lognormal, gamma, etc.) is not specified. It is only specified that the two sets of data have the same distribution.

The results of the statistical comparisons are as follows. For each of the three radionuclide and each of the four waste types, there were no significant differences between the means, between the variances, and between the distributions (except in one case). The exceptional case is the comparison of the distributions of alpha in SST liquid samples. For this analyte, the distribution of alpha obtained by omitting all observations below the DL (model M1) is significantly different ( 0.05 level of significance) from the distribution of alpha obtained by replacing all observations below the DL by zero (model M3). The observed means and variances are given in Appendix C, Table C-1.

Figures 9, 10, and 11 are quantile plots of the two sets of data by radionuclide (using model M1) and by waste type. The number of points is the number of tanks with data. The $x$-axis represents the quantiles; i.e., the ordered values of the data. The $y$-axis represents the percentile points. That is, the point 0.50 corresponds to the median, the point 0.95 the quantile for the $95^{\text {th }}$ percentile, etc. As these figures demonstrate, there is little evidence to show that the complete data set is different from the subset used in the ULD. The 
HNF-4534 Rev. 1

corresponding plots, based on the other two methods for incorporating observations below the $\mathrm{DL}$, are similar.

Three models were used to incorporate observations below the detection limit. In the first model, the observations below the detection limits were omitted; in the second, the observations below the detection limits were replaced by the detection limit; and in the third model, the observations below the detection limits were replace by zero. For each of the four waste types, the means, variances and distributions of the ULDs obtained using the three modes were compared using S-PLUS. The results of these comparisons were that there were no significant differences ( 0.05 level of significance) between the means, between the variances, and between the distributions. The observed ULD means and variances are given in Appendix C, Table C-2.

Table C-3 lists the $95^{\star}$, the $99^{\star}$ percentile points, and the $95 / 95$ and $95 / 99$ tolerance limits for the three models. These points are based on the lognormal distribution. For the different waste types, there is little difference in the percentile points and the tolerance limits given by the three models.

Based on the results of the statistical comparisons given above, there is no reason to believe that the ULDs computed from subsets of the radionuclide data would be different from those computed from a complete set of data, provided the complete set were available. In addition, the differences in percentile points and tolerance limits using the three models are small. 


\section{RPP-5924 REV 0}

\section{HNF-4534 Rev. 1}

Figure 1. ULD Lognormal Density and Histogram Single Shell Tanks, Solid Samples

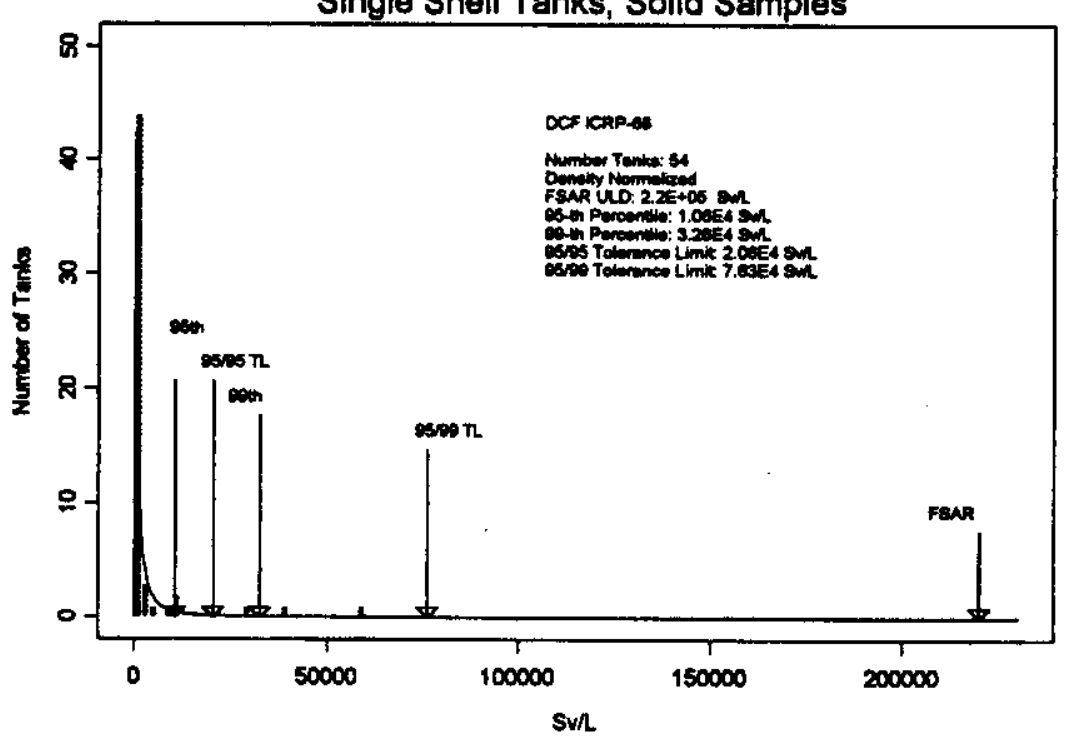

Figure 2. ULD Lognormal Density and Histogram Single Shell Tanks, Liquid Samples

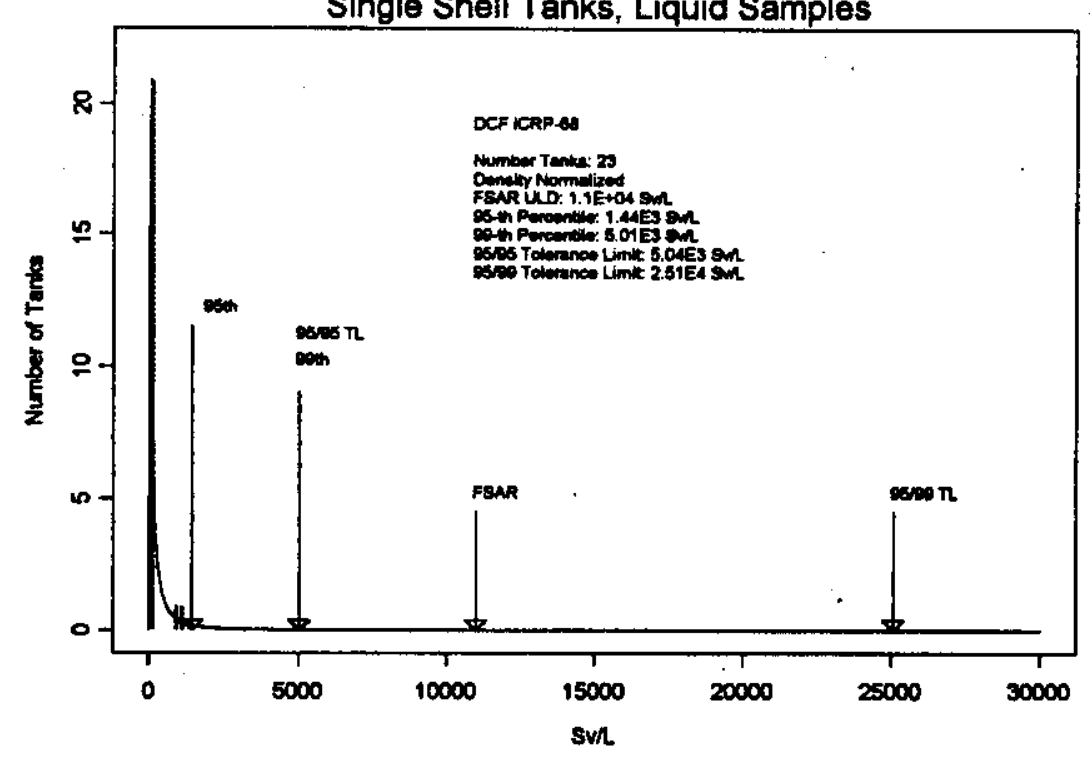




\section{RPP-5924 REV 0}

\section{HNF-4534 Rev. 1}

Figure 3. ULD Lognormal Density and Histogram Double Shell Tanks, Solid Samples

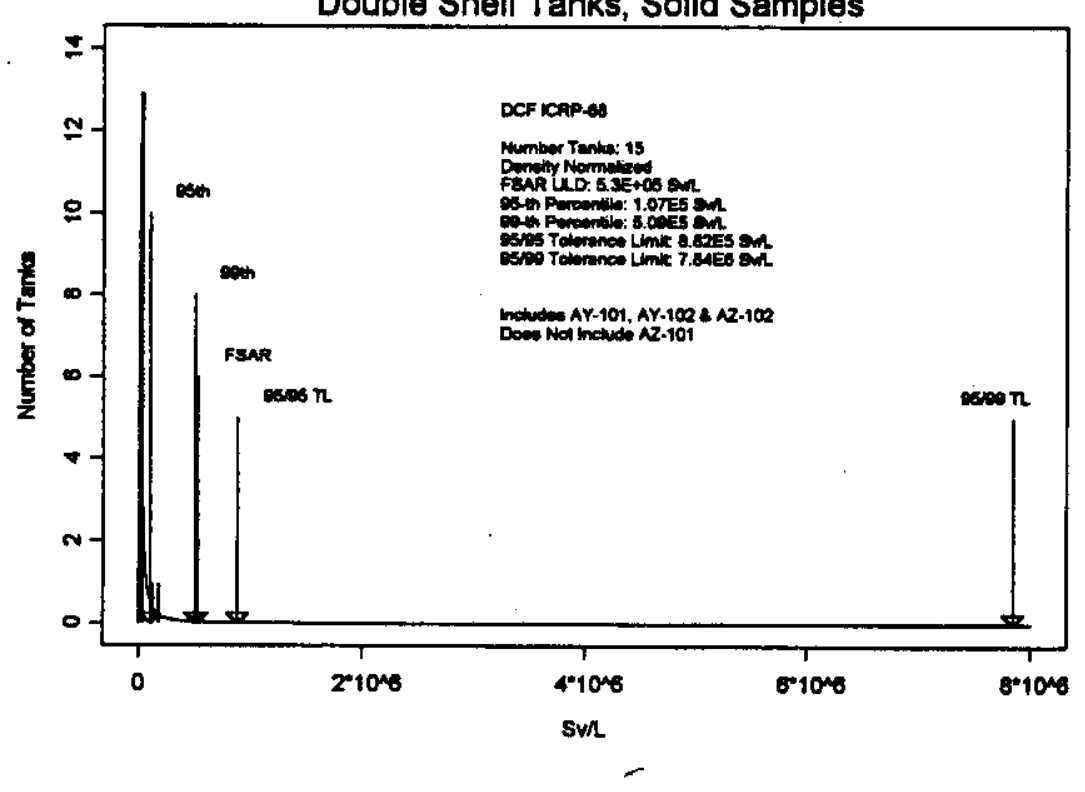

Figure 4. ULD Lognormal Density and Histogram

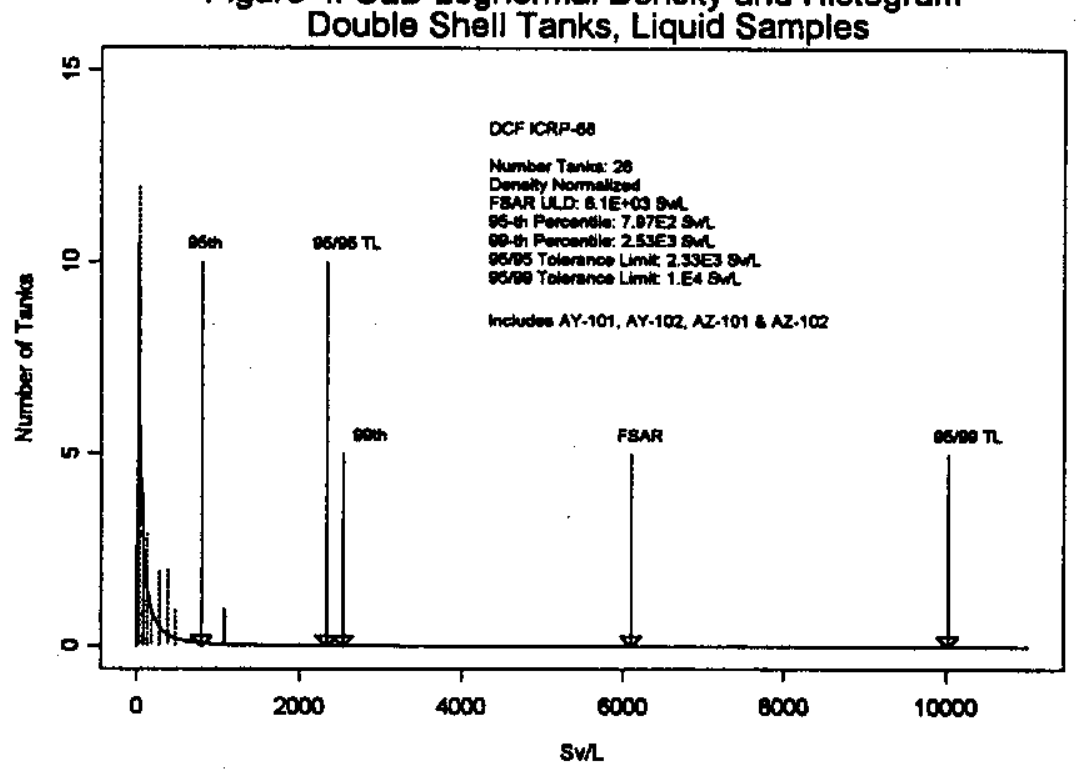

14 
HNF-4534 Rev. 1

Figure 5. ULD Lognormal Density and Histogram Single Shell Tanks, Solid Samples

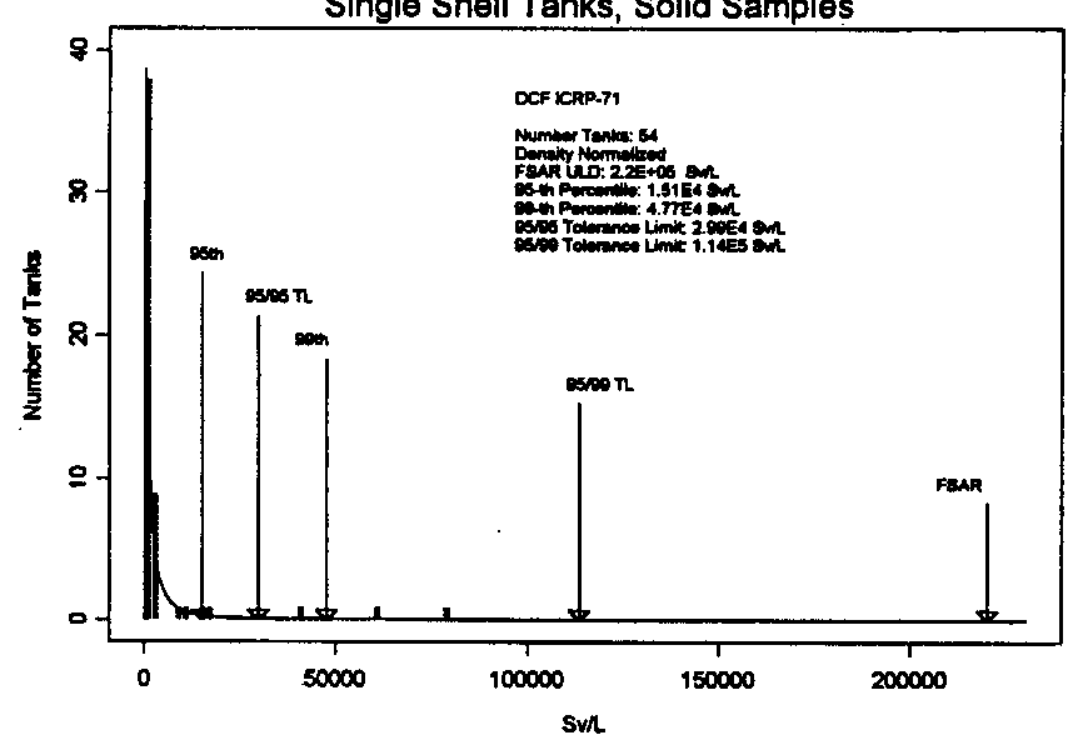

Figure 6. ULD Lognormal Density and Histogram Single Shell Tanks, Liquid Samples

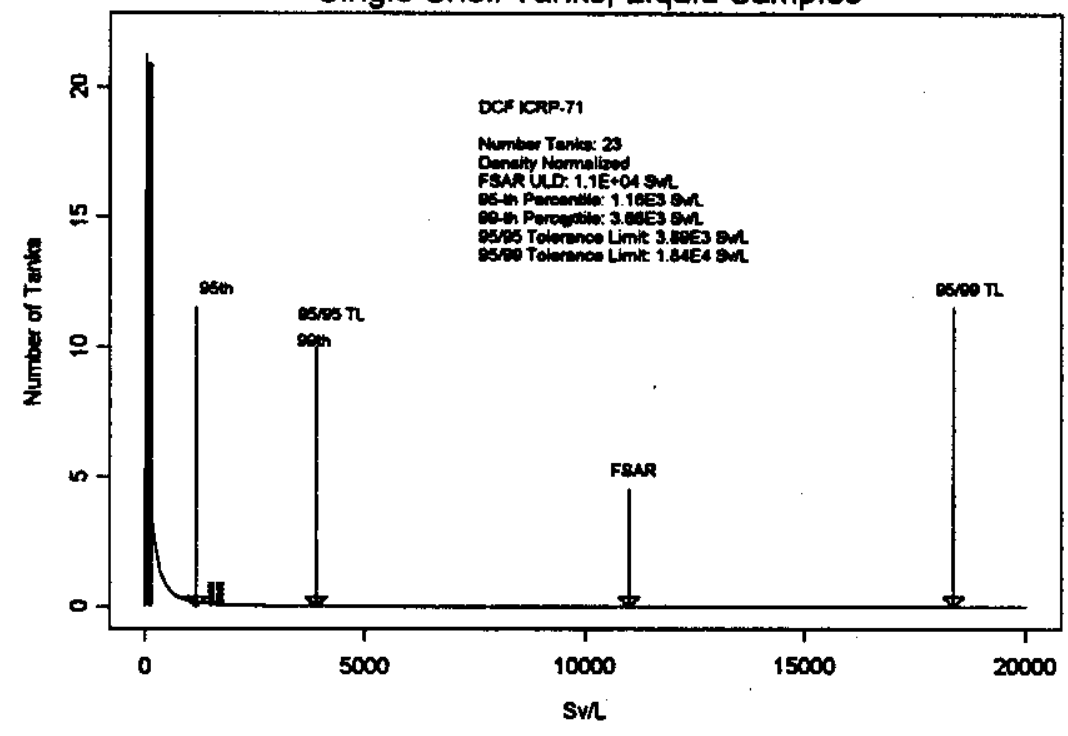

15 


\section{RPP-5924 REV 0}

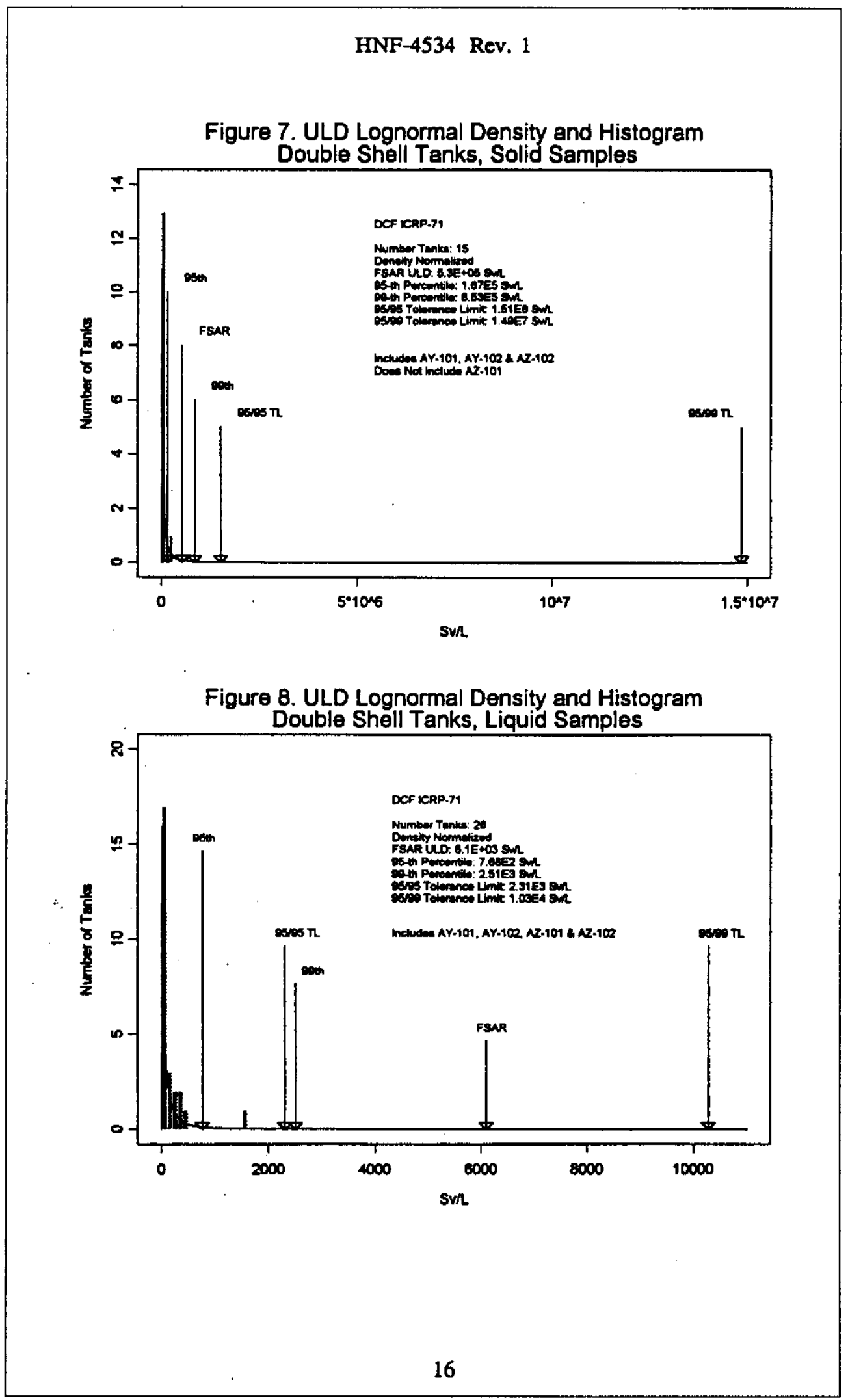


HNF-4534 Rev. 1
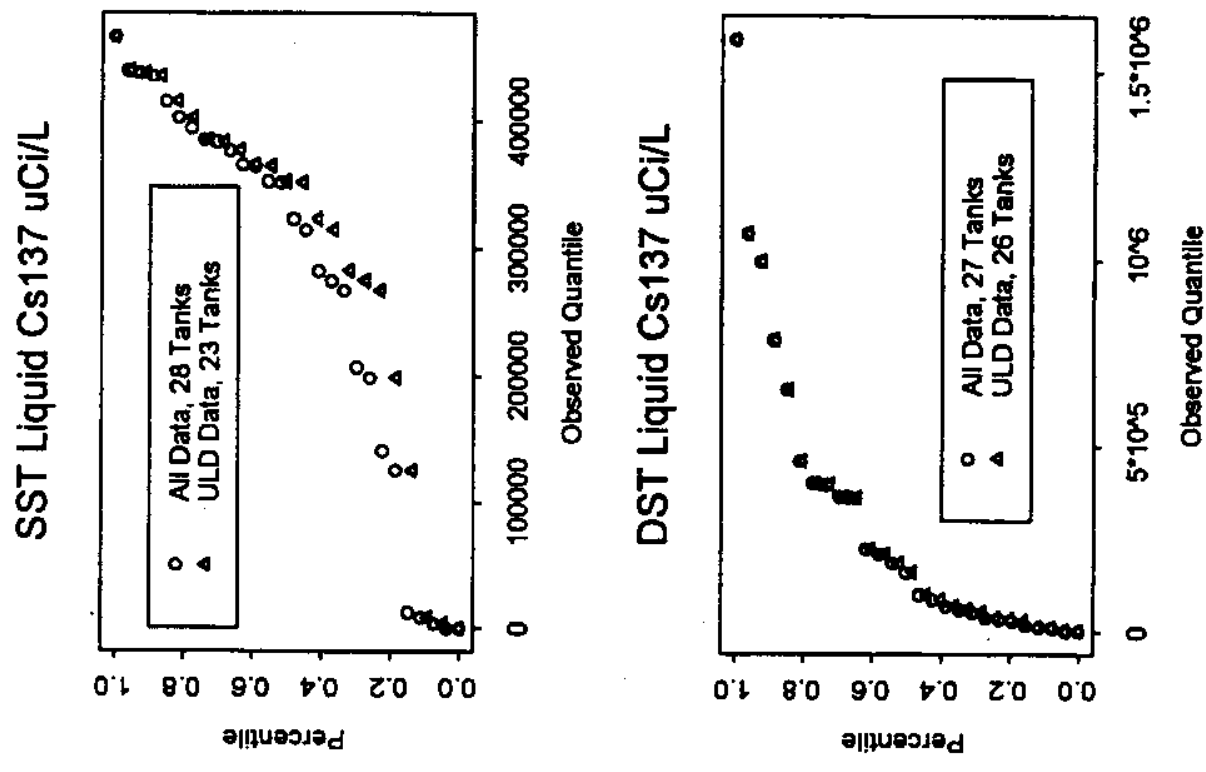

告
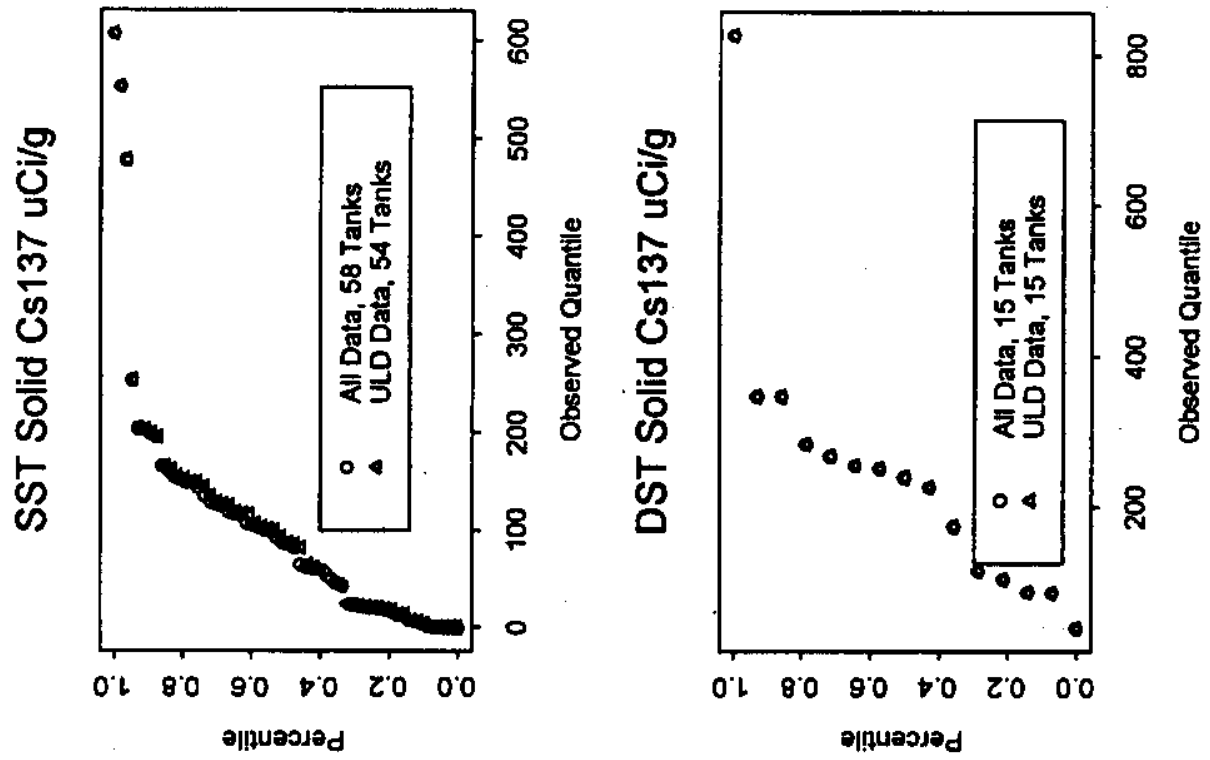


\section{RPP-5924 REV 0}

HNF-4534 Rev. 1
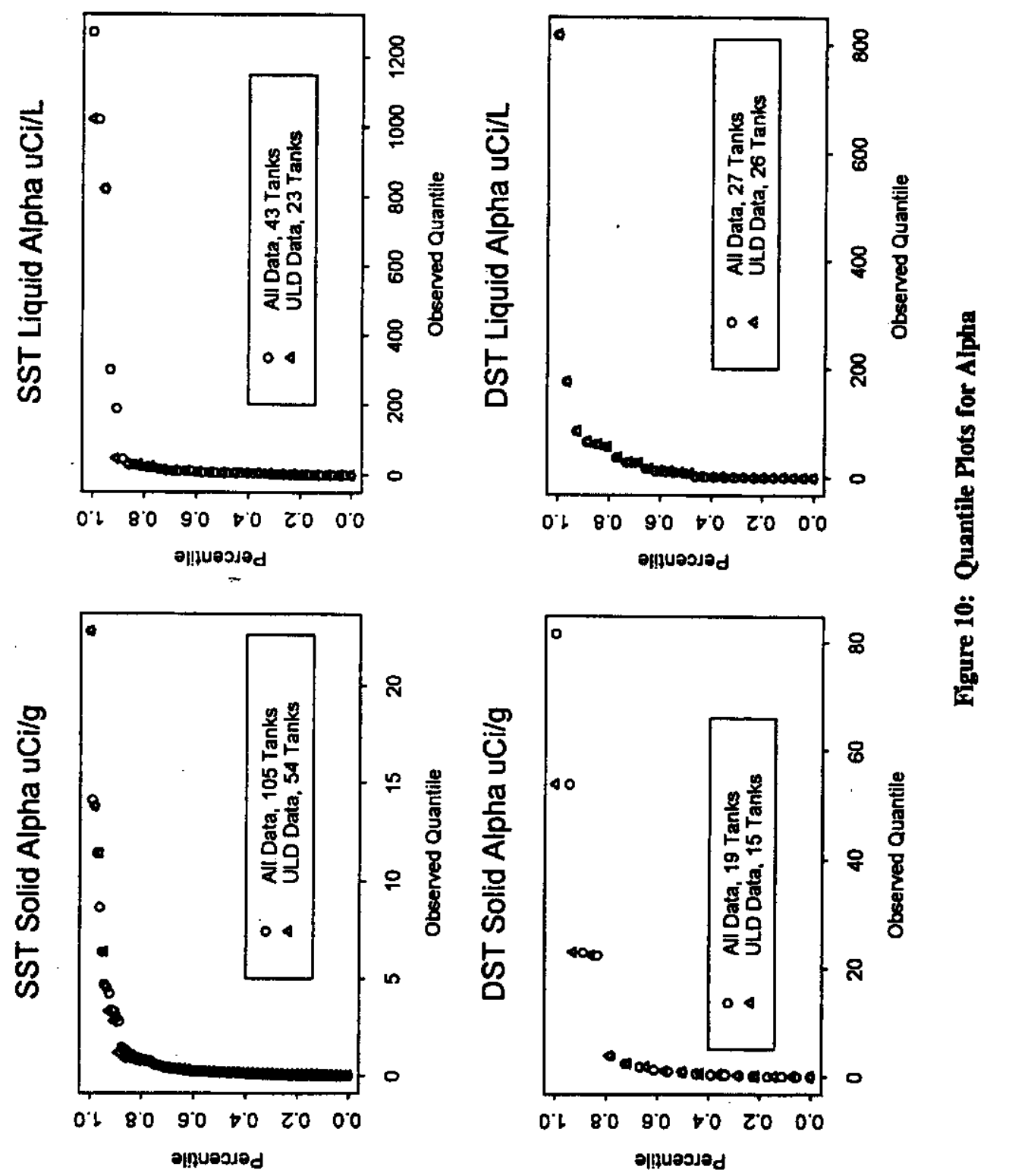
RPP-5924 REV 0

HNF-4534 Rev. 1
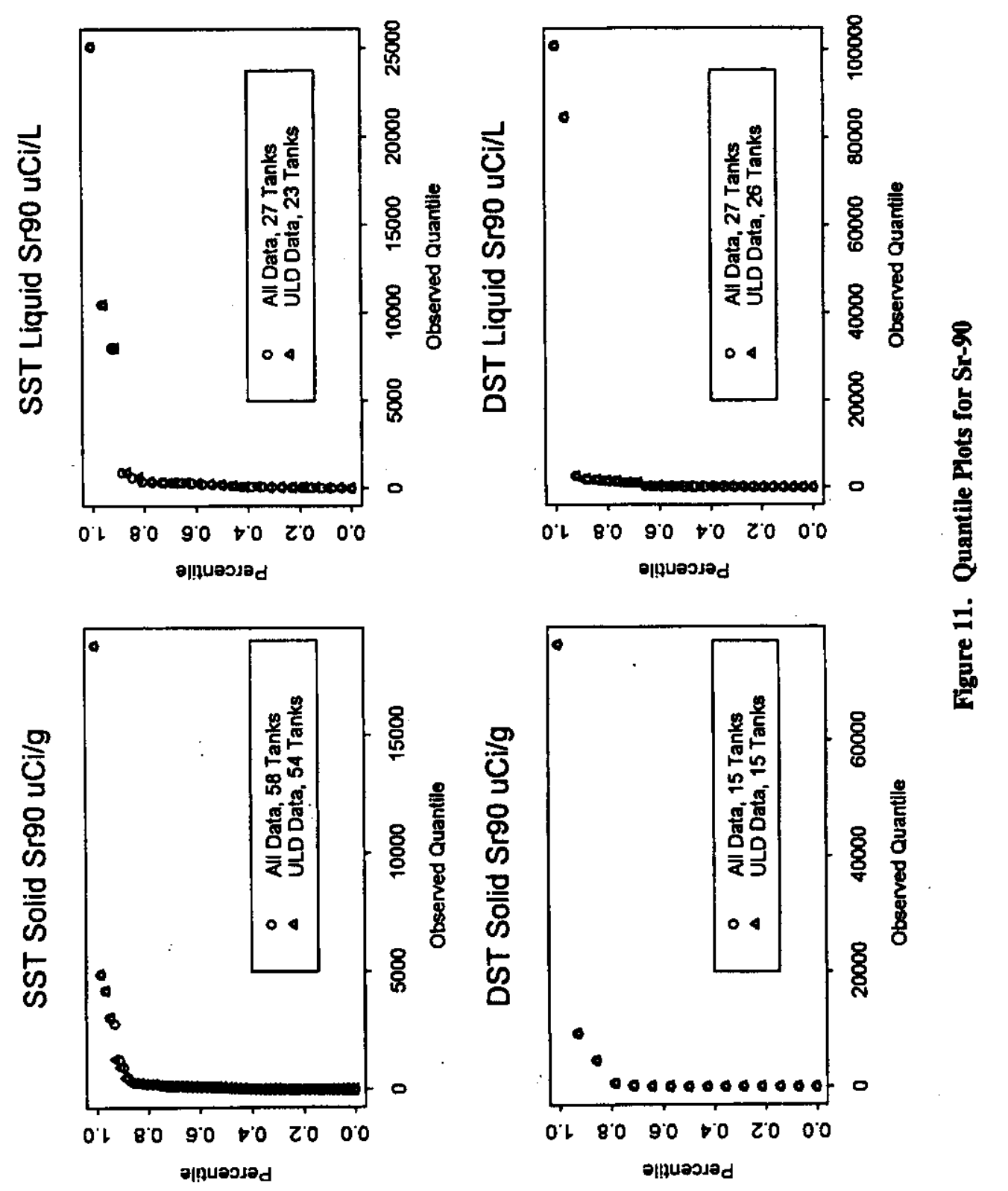
HNF-4534 Rev. 1

\section{S.0 REFERENCES}

Brevick, C. H., 2000, Attachment to Deliverable for Contract 4976, Release 8, Updated Dose Methods (L-03), (internal memorandum LMHC96W0-0006, CO-00-RPP-270 to W. L. Cowley, March 27), Fluor Federal Services, Richland, Washington..

Brevick, C. H., L. A. Gaddis, and E. D. Johnson, 1996, Tank Waste Source Term Inventory Validation, WHC-SD-WM-ER-400, Rev. 0-A, Westinghouse Hanford Company, Richland, Washington

FDH, 1999a, Tank Waste Remediation System Basis for Interim Operation, HNF-SD-WM-BIO-001, Revision 1-C, Fluor Daniel Hanford, Inc., Richland, Washington.

FDH, 1999b, Tank Waste Remediation System Final Safety Analysis Report, HNF-SD-WM-SAR-067, Rev. 0, Duke Engineering and Services Hanford, Richland, Washington.

Jensen, L., S.R. Wilmarth, and J. M. Grigsby, 1998, Sample Based Unit Liter Dose Estimates for Use in the Gas Release Event Safety Analysis Tool, HNF-2589, Rev. 0, Fluor Daniel Hanford, Inc., Richland, Washington.

Jensen, L., and S.R. Wilmarth, 1999, Sample Based Unit Liter Dose Estimates, HNF-4534, Rev. 0, Fluor Daniel Hanford, Inc., Richland, Washington.

Natrella, M. G., 1963, Experimental Statistics, National Bureau of Standards Handbook 91, U. S. Department of Commerce.

S-PLUS, 2000, Data Analysis Produces Division, MathSoft, Seattle, Washington.

WHC, 1996, Development of Radiological Concentrations and Unit Liter Doses for TWRS FSAR Radiological Consequence Calculations, WHC-SD-WM-SARR-037, Rev. 0, Westinghouse Hanford Company, Richland, Washington. 
HNF-4534 Rev. 1

\section{APPENDIX A}

\section{A.0 ANALYTE MEANS TABLES}

In Tables A-1 to A-13, the columns labeled "analyte" denote the type of data used to estimate the mean. That is, the symbol ${ }^{137} \mathrm{Cs}$ is used to indicate that the mean of all the ${ }^{137} \mathrm{Cs}$ data for the tank is reported. For alpha, GA indicates that the mean of the gross alpha data is reported; ${ }^{241} \mathrm{Am}$, the mean of the ${ }^{241} \mathrm{Am}$ data. For strontium, ${ }^{19190} \mathrm{Sr}$ indicates that the mean of ${ }^{89 / 90} \mathrm{Sr}$ is reported; ${ }^{90} \mathrm{Sr}$, the mean of ${ }^{90} \mathrm{Sr}$ data; ${ }^{8990} \mathrm{Sr} \&{ }^{80} \mathrm{Sr}$, the mean of the combined ${ }^{8990} \mathrm{Sr}$ and ${ }^{90} \mathrm{Sr}$ data. The columns labeled M1, M2, and M3 are analyte concentration means when the below detection limit observations are omitted, replaced by the detection limit, and replaced by zero respectively. Num. Obs are the total number of observations and Num. Above DL are the number of observations above the detection limit. NA means not available.

\section{Table A-1. Mean ${ }^{17} \mathrm{Cs}$ Concentration $(\mu \mathrm{Ci} / \mathrm{g})$, SST Solid Samples (2 sheets)}

\begin{tabular}{|c|c|c|c|c|c|c|}
\hline Tank & Avialyte & Nomiobs. & Above DI & nil & 10 & . 113 \\
\hline $241-\mathrm{A}-101$ & ${ }^{137} \mathrm{Cs}$ & 90 & 90 & $2.03 \mathrm{E}+02$ & $2.03 \mathrm{E}+02$ & $2.03 E+02$ \\
\hline $241-\mathrm{AX}-101$ & ${ }^{137} \mathrm{Cs}$ & 96 & 96 & $1.99 \mathrm{E}+02$ & $1.99 \mathrm{E}+02$ & $1.99 \mathrm{E}+02$ \\
\hline $241-\mathrm{AX}-104$ & ${ }^{137} \mathrm{Cs}$ & 10 & 10 & $6.07 \mathrm{E}+02$ & $6.07 \mathrm{E}+02$ & $6.07 \mathrm{E}+02$ \\
\hline 241-B-106 & ${ }^{137} \mathrm{Cs}$ & 20 & 20 & $2.03 \mathrm{E}+01$ & $2.03 \mathrm{E}+01$ & $2.03 E+01$ \\
\hline $241-\mathrm{B}-108$ & ${ }^{137} \mathrm{Cs}$ & 16 & 16 & $1.72 \mathrm{E}+01$ & $1.72 \mathrm{E}+01$ & $1.72 \mathrm{E}+01$ \\
\hline $241-\mathrm{B}-110$ & ${ }^{137} \mathrm{Cs}$ & 14 & 14 & $1.31 \mathrm{E}+01$ & $1.31 \mathrm{E}+01$ & $1.31 E+01$ \\
\hline $241-B-111$ & ${ }^{137} \mathrm{Cs}$ & 20 & 20 & $1.49 \mathrm{E}+02$ & $1.49 \mathrm{E}+02$ & $1.49 \mathrm{E}+02$ \\
\hline 241-B-201 & ${ }^{137} \mathrm{Cs}$ & 38 & 38 & $4.59 \mathrm{E}+00$ & $4.59 \mathrm{E}+00$ & $4.59 \mathrm{E}+\infty 0$ \\
\hline 241-B-202 & ${ }^{137} \mathrm{Cs}$ & 8 & 6 & $1.26 \mathrm{E}-01$ & $1.00 \mathrm{E}-01$ & $9.44 \mathrm{E}-02$ \\
\hline $241-B-204$ & ${ }^{137} \mathrm{Cs}$ & 2 & 0 & NA & $3.14 \mathrm{E}-02$ & $0.00 \mathrm{E}+00$ \\
\hline 241-BX-104 & ${ }^{137} \mathrm{Cs}$ & 8 & 8 & $6.03 \mathrm{E}+01$ & $6.03 E+01$ & $6.03 \mathrm{E}+01$ \\
\hline $241-\mathrm{BX}-107$ & ${ }^{137} \mathrm{Cs}$ & 16 & 16 & $2.21 \mathrm{E}+01$ & $2.21 \mathrm{E}+01$ & $2.21 \mathrm{E}+01$ \\
\hline $241-\mathrm{BX}-109$ & ${ }^{137} \mathrm{Cs}$ & 32 & 32 & $1.32 \mathrm{E}+01$ & $1.32 \mathrm{E}+01$ & $1.32 \mathrm{E}+01$ \\
\hline $241-\mathrm{BX}-112$ & ${ }^{197} \mathrm{Cs}$ & 20 & 20 & $5.09 \mathrm{E}+01$ & $5.09 \mathrm{E}+01$ & $5.09 \mathrm{E}+01$ \\
\hline $241-\mathrm{BY}-104$ & ${ }^{137} \mathrm{Cs}$ & 60 & 60 & $1.03 \mathrm{E}+02$ & $1.03 \mathrm{E}+02$ & $1.03 \mathrm{E}+02$ \\
\hline 241-BY-105 & ${ }^{137} \mathrm{Cs}$ & 44 & 44 & $6.55 \mathrm{E}+01$ & $6.55 \mathrm{E}+01$ & $6.55 \mathrm{E}+01$ \\
\hline $241-B Y-106$ & ${ }^{137} \mathrm{Cs}$ & 96 & 96 & $1.00 \mathrm{E}+02$ & $1.00 \mathrm{E}+02$ & $1.00 \mathrm{E}+02$ \\
\hline $241-B Y-107$ & ${ }^{137} \mathrm{Cs}$ & 8 & 8 & $1.25 \mathrm{E}+02$ & $1.25 \mathrm{E}+02$ & $1.25 \mathrm{E}+02$ \\
\hline 241-BY-108 & ${ }^{137} \mathrm{Cs}$ & 8 & 8 & $6.30 \mathrm{E}+01$ & $6.30 \mathrm{E}+01$ & $6.30 \mathrm{E}+01$ \\
\hline $241-B Y-110$ & ${ }^{137} \mathrm{Cs}$ & 216 & 216 & $9.29 \mathrm{E}+01$ & $9.29 \mathrm{E}+01$ & $9.29 \mathrm{E}+01$ \\
\hline $241-\mathrm{C}-103$ & ${ }^{137} \mathrm{Cs}$ & 10 & 10 & $1.35 \mathrm{E}+02$ & $1.35 \mathrm{E}+02$ & $1.35 \mathrm{E}+02$ \\
\hline
\end{tabular}


HNF-4534 Rev. 1

Table A-1. Mean ${ }^{13} \mathrm{Cs}$ Concentration $(\mu \mathrm{Ci} / \mathrm{g}$ ), SST Solid Samples (2 sheets)

\begin{tabular}{|c|c|c|c|c|c|c|}
\hline Tank & Amalyte & finin. Obs & Nurim. & 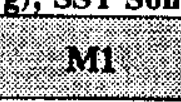 & 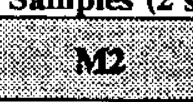 & 18 \\
\hline $241-\mathrm{C}-104$ & ${ }^{137} \mathrm{Cs}$ & 50 & 49 & $6.15 \mathrm{E}+01$ & $6.49 \mathrm{E}+01$ & $6.03 E+01$ \\
\hline 241-C-106 & ${ }^{137} \mathrm{Cs}$ & 22 & 22 & $5.53 \mathrm{E}+02$ & $5.53 \mathrm{E}+02$ & $5.53 \mathrm{E}+02$ \\
\hline $241-C-108$ & ${ }^{137} \mathrm{Cs}$ & 22 & 22 & $1.66 \mathrm{E}+02$ & $1.66 \mathrm{E}+02$ & $1.66 \mathrm{E}+02$ \\
\hline $241-C-109$ & ${ }^{137} \mathrm{Cs}$ & 40 & 40 & $4.77 \mathrm{E}+02$ & $4.77 \mathrm{E}+02$ & $4.77 \mathrm{E}+02$ \\
\hline $241-C-110$ & ${ }^{137} \mathrm{Cs}$ & 18 & 18 & $1.86 \mathrm{E}+01$ & $1.86 \mathrm{E}+01$ & $1.86 \mathrm{E}+01$ \\
\hline $241-C-111$ & ${ }^{137} \mathrm{Cs}$ & 4 & 4 & $4.32 \mathrm{E}+01$ & $4.32 \mathrm{E}+01$ & $4.32 E+01$ \\
\hline $241-C-112$ & ${ }^{137} \mathrm{Cs}$ & 69 & 69 & $2.04 \mathrm{E}+02$ & $2.04 \mathrm{E}+02$ & $2.04 \mathrm{E}+02$ \\
\hline $241-S-101$ & ${ }^{137} \mathrm{Cs}$ & 58 & 58 & $1.29 \mathrm{E}+02$ & $1.29 \mathrm{E}+02$ & $1.29 \mathrm{E}+02$ \\
\hline $241-S-102$ & ${ }^{137} \mathrm{Cs}$ & 24 & 24 & $1.17 \mathrm{E}+02$ & $1.17 \mathrm{E}+02$ & $1.17 \mathrm{E}+02$ \\
\hline $241-S-104$ & ${ }^{137} \mathrm{Cs}$ & 24 & 24 & $5.84 \mathrm{E}+01$ & $5.84 \mathrm{E}+01$ & $5.84 \mathrm{E}+01$ \\
\hline $241-S-106$ & ${ }^{137} \mathrm{Cs}$ & 28 & 28 & $1.01 \mathrm{E}+02$ & $1.01 \mathrm{E}+02$ & $1.01 \mathrm{E}+02$ \\
\hline $241-S-107$ & ${ }^{137} \mathrm{Cs}$ & 92 & 92 & $8.22 \mathrm{E}+01$ & $8.22 \mathrm{E}+01$ & $8.22 \mathrm{E}+01$ \\
\hline $241-S-109$ & ${ }^{137} \mathrm{Cs}$ & 30 & 30 & $7.58 \mathrm{E}+00$ & $7.58 \mathrm{E}+00$ & $7.58 \mathrm{E}+00$ \\
\hline $241-S-110$ & ${ }^{137} \mathrm{Cs}$ & 68 & 68 & $8.78 \mathrm{E}+01$ & $8.78 \mathrm{E}+01$ & $8.78 E+01$ \\
\hline 241-S-111 & ${ }^{137} \mathrm{Cs}$ & 52 & 52 & $1.19 E+02$ & $1.19 \mathrm{E}+02$ & $1.19 \mathrm{E}+02$ \\
\hline $241-S X-101$ & ${ }^{137} \mathrm{Cs}$ & 50 & 50 & $1.07 \mathrm{E}+02$ & $1.07 \mathrm{E}+02$ & $1.07 \mathrm{E}+02$ \\
\hline $241-S X-102$ & ${ }^{137} \mathrm{Cs}$ & 4 & 4 & $1.49 \mathrm{E}+02$ & $1.49 \mathrm{E}+02$ & $1.49 \mathrm{E}+02$ \\
\hline $241-S X-103$ & ${ }^{137} \mathrm{Cs}$ & 56 & 56 & $1.27 \mathrm{E}+02$ & $1.27 \mathrm{E}+02$ & $1.27 \mathrm{E}+02$ \\
\hline 241-SX-104 & ${ }^{137} \mathrm{Cs}$ & 2 & 2 & $1.06 \mathrm{E}+02$ & $1.06 \mathrm{E}+02$ & $1.06 \mathrm{E}+02$ \\
\hline $241-S X-108$ & ${ }^{137} \mathrm{Cs}$ & 8 & 8 & $1.95 \mathrm{E}+02$ & $1.95 \mathrm{E}+02$ & $1.95 \mathrm{E}+02$ \\
\hline $241-\Upsilon-102$ & ${ }^{137} \mathrm{Cs}$ & 6 & 6 & $2.09 \mathrm{E}+01$ & $2.09 \mathrm{E}+01$ & $2.09 \mathrm{E}+01$ \\
\hline $241-\mathrm{T}-104$ & ${ }^{137} \mathrm{Cs}$ & 12 & 12 & $2.07 \mathrm{E}-01$ & $2.07 \mathrm{E}-01$ & $2.07 \mathrm{E}-01$ \\
\hline $241-T-105$ & ${ }^{137} \mathrm{Cs}$ & 12 & 12 & $4.57 \mathrm{E}+01$ & $4.57 \mathrm{E}+01$ & $4.57 \mathrm{E}+01$ \\
\hline $241-\mathrm{T}-107$ & ${ }^{137} \mathrm{Cs}$ & 38 & 38 & $2.06 \mathrm{E}+01$ & $2.06 \mathrm{E}+01$ & $2.06 \mathrm{E}+01$ \\
\hline $241-\mathrm{T}-108$ & ${ }^{137} \mathrm{Cs}$ & 4 & 4 & $2.00 \mathrm{E}+00$ & $2.00 \mathrm{E}+00$ & $2.00 \mathrm{E}+00$ \\
\hline $241-\mathrm{T}-111$ & ${ }^{137} \mathrm{Cs}$ & 30 & 30 & $1.34 \mathrm{E}-01$ & $1.34 \mathrm{E}-01$ & $1.34 \mathrm{E}-01$ \\
\hline $241-\mathrm{T}-201$ & ${ }^{137} \mathrm{Cs}$ & 4 & 3 & $3.46 \mathrm{E}-02$ & $2.80 \mathrm{E}-02$ & $2.59 \mathrm{E}-02$ \\
\hline $241-\mathrm{T}-202$ & ${ }^{137} \mathrm{Cs}$ & 2 & 0 & NA & $2.82 \mathrm{E}-02$ & $0.00 \mathrm{E}+00$ \\
\hline $241-\mathrm{T}-203$ & ${ }^{137} \mathrm{Cs}$ & 2 & 0 & NA & $1.81 \mathrm{E}-02$ & $0.00 \mathrm{E}+00$ \\
\hline 241-T-204 & ${ }^{137} \mathrm{Cs}$ & 2 & 2 & $7.76 \mathrm{E}-03$ & $7.76 \mathrm{E}-03$ & $7.76 \mathrm{E}-03$ \\
\hline 241-TX-113 & ${ }^{137} \mathrm{Cs}$ & 36 & 36 & $6.58 \mathrm{E}+00$ & $6.58 \mathrm{E}+00$ & $6.58 \mathrm{E}+00$ \\
\hline $241-\mathrm{TX}-118$ & ${ }^{137} \mathrm{Cs}$ & 32 & 32 & $2.33 \mathrm{E}+01$ & $2.33 \mathrm{E}+01$ & $2.33 \mathrm{E}+01$ \\
\hline $241-U-102$ & ${ }^{137} \mathrm{Cs}$ & 56 & 56 & $1.62 \mathrm{E}+02$ & $1.62 \mathrm{E}+02$ & $1.62 \mathrm{E}+02$ \\
\hline 241-U-103 & ${ }^{137} \mathrm{Cs}$ & 6 & 6 & $2.53 \mathrm{E}+02$ & $2.53 \mathrm{E}+02$ & $2.53 \mathrm{E}+02$ \\
\hline $241-U-105$ & ${ }^{137} \mathrm{Cs}$ & 74 & 74 & $1.55 \mathrm{E}+02$ & $1.55 \mathrm{E}+02$ & $1.55 \mathrm{E}+02$ \\
\hline $241-\mathrm{U}-106$ & ${ }^{137} \mathrm{Cs}$ & 34 & 34 & $1.52 \mathrm{E}+02$ & $1.52 \mathrm{E}+02$ & $1.52 \mathrm{E}+02$ \\
\hline $241-U-107$ & ${ }^{137} \mathrm{Cs}$ & 16 & 16 & $8.55 \mathrm{E}+01$ & $8.55 \mathrm{E}+01$ & $8.55 \mathrm{E}+01$ \\
\hline $241-U-108$ & ${ }^{137} \mathrm{Cs}$ & 106 & 106 & $1.44 \mathrm{E}+02$ & $1.44 \mathrm{E}+02$ & $1.44 \mathrm{E}+02$ \\
\hline $241-\mathrm{U}-109$ & ${ }^{137} \mathrm{Cs}$ & 110 & 110 & $1.16 \mathrm{E}+02$ & $1.16 \mathrm{E}+02$ & $1.16 \mathrm{E}+02$ \\
\hline $241-U-110$ & ${ }^{137} \mathrm{Cs}$ & 92 & 88 & $2.41 \mathrm{E}+01$ & $2.30 \mathrm{E}+01$ & $2.30 \mathrm{E}+01$ \\
\hline
\end{tabular}

A-2 
HNF-4534 Rev. 1

Table A-2. Mean Alpha Concentration $(\mu \mathrm{Ci} / \mathrm{g})$, SST Solid Samples (3 sheets)

\begin{tabular}{|c|c|c|c|c|c|c|}
\hline manil. & inalyts & Num. obs & A bove DL & mi & $\ln$ & $\sqrt{13}$ \\
\hline 241-A-101 & $\mathrm{GA}$ & 60 & 46 & $6.15 \mathrm{E}-02$ & $4.83 \mathrm{E}-02$ & $4.71 \mathrm{E}-02$ \\
\hline $241-\mathrm{A}-102$ & $\mathrm{GA}$ & 4 & 4 & $4.68 \mathrm{E}+00$ & $4.68 \mathrm{E}+00$ & $4.68 \mathrm{E}+00$ \\
\hline $241-\mathrm{AX}-101$ & GA & 60 & 44 & $5.17 \mathrm{E}-02$ & $4.10 \mathrm{E}-02$ & $3.79 \mathrm{E}-02$ \\
\hline 241-AX-102 & GA & 4 & 4 & $1.24 \mathrm{E}+00$ & $1.24 \mathrm{E}+00$ & $1.24 \mathrm{E}+00$ \\
\hline 241-AX-103 & GA & 6 & 6 & $4.48 \mathrm{E}-02$ & $4.48 \mathrm{E}-02$ & $4.48 \mathrm{E}-02$ \\
\hline $241-\mathrm{AX}-104$ & $\mathrm{GA}$ & 6 & 6 & $1.38 \mathrm{E}+01$ & $1.38 \mathrm{E}+01$ & $1.38 \mathrm{E}+01$ \\
\hline $241-\mathrm{B}-101$ & $\mathrm{GA}$ & 20 & 17 & $2.99 \mathrm{E}+00$ & $2.57 \mathrm{E}+00$ & $2.54 \mathrm{E}+00$ \\
\hline $241-\mathrm{B}-102$ & $\mathrm{GA}$ & 4 & 0 & NA & $3.56 \mathrm{E}-01$ & $0.00 \mathrm{E}+00$ \\
\hline $241-\mathrm{B}-103$ & $\mathrm{GA}$ & 4 & 4 & $2.14 \mathrm{E}-01$ & $2.14 \mathrm{E}-01$ & $2.14 \mathrm{E}-01$ \\
\hline $241-\mathrm{B}-104$ & $\mathrm{GA}$ & 54 & 52 & $4.46 \mathrm{E}-02$ & $5.45 \mathrm{E}-02$ & $4.29 \mathrm{E}-02$ \\
\hline $241-\mathrm{B}-106$ & $\mathrm{GA}$ & 20 & 8 & $4.92 \mathrm{E}-02$ & $4.66 \mathrm{E}-02$ & $1.97 \mathrm{E}-02$ \\
\hline $241-\mathrm{B}-107$ & $\mathrm{GA}$ & 16 & 16 & $6.33 E-02$ & $6.33 \mathrm{E}-02$ & $6.33 \mathrm{E}-02$ \\
\hline $241-B-108$ & GA & 14 & 13 & $7.90 \mathrm{E}-03$ & $8.22 \mathrm{E}-03$ & $7.33 \mathrm{E}-03$ \\
\hline 241-B-109 & GA & 10 & 10 & $5.64 \mathrm{E}-02$ & $5.64 \mathrm{E}-02$ & $5.64 \mathrm{E}-02$ \\
\hline $241-\mathrm{B}-110$ & GA & 14 & 14 & $7.80 \mathrm{E}-02$ & $7.80 \mathrm{E}-02$ & $7.80 \mathrm{E}-02$ \\
\hline 241-B-111 & GA & 10 & 10 & $1.42 \mathrm{E}-01$ & $1.42 \mathrm{E}-01$ & $1.42 \mathrm{E}-01$ \\
\hline $241 \cdot B-112$ & $\mathrm{GA}$ & 6 & 4 & $6.57 \mathrm{E}-03$ & $4.64 \mathrm{E}-03$ & $4.38 \mathrm{E}-03$ \\
\hline 241-B-201 & GA & 6 & 6 & $9.07 \mathrm{E}-01$ & $9.07 \mathrm{E}-01$ & $9.07 \mathrm{E}-01$ \\
\hline $241-\mathrm{B}-202$ & $\mathrm{GA}$ & 10 & 10 & $4.04 \mathrm{E}-01$ & $4.04 \mathrm{E}-01$ & $4.04 \mathrm{E}-01$ \\
\hline $241-\mathrm{B}-203$ & $\mathrm{GA}$ & 44 & 44 & $2.14 \mathrm{E}-01$ & $2.14 \mathrm{E}-01$ & $2.14 \mathrm{E}-01$ \\
\hline $241-\mathrm{B}-204$ & $\mathrm{GA}$ & 52 & 52 & $2.64 \mathrm{E}-01$ & $2.64 \mathrm{E}-01$ & $2.64 \mathrm{E}-01$ \\
\hline $241-\mathrm{BX}-101$ & GA & 10 & 10 & $9.75 \mathrm{E}-01$ & $9.75 \mathrm{E}-01$ & $9.75 \mathrm{E}-01$ \\
\hline $241-\mathrm{BX}-103$ & $\mathrm{GA}$ & 12 & 11 & $3.37 \mathrm{E}+00$ & $3.13 \mathrm{E}+00$ & $3.09 \mathrm{E}+00$ \\
\hline 241-BX-104 & GA & 8 & 8 & $8.22 \mathrm{E}-01$ & $8.22 \mathrm{E}-01$ & $8.22 \mathrm{E}-01$ \\
\hline $241-\mathrm{BX}-105$ & $\mathrm{GA}$ & 8 & 8 & $2.21 \mathrm{E}-01$ & $2.21 E-01$ & $2.21 \mathrm{E}-01$ \\
\hline $241-\mathrm{BX}-106$ & $\mathrm{GA}$ & 4 & 4 & $5.90 \mathrm{E}-01$ & $5.90 \mathrm{E}-01$ & $5.90 \mathrm{E}-01$ \\
\hline 241-BX-107 & $\mathrm{GA}$ & 15 & 15 & $1.23 \mathrm{E}-01$ & $1.23 \mathrm{E}-01$ & $1.23 \mathrm{E}-01$ \\
\hline 241-BX-108 & $\mathrm{GA}$ & 8 & 8 & $8.16 \mathrm{E}-02$ & $8.16 \mathrm{E}-02$ & $8.16 \mathrm{E}-02$ \\
\hline 241-BX-109 & GA & 32 & 6 & $4.99 \mathrm{E}-02$ & $5.91 \mathrm{E}-02$ & $9.35 \mathrm{E}-03$ \\
\hline $241-\mathrm{BX}-110$ & $\mathrm{GA}$ & 16 & 10 & $1.18 \mathrm{E}-02$ & $8.23 \mathrm{E}-03$ & $7.38 \mathrm{E}-03$ \\
\hline 241-BX-111 & $\mathrm{GA}$ & 12 & 7 & $2.64 \mathrm{E}-03$ & $2.28 \mathrm{E}-03$ & $1.54 \mathrm{E}-03$ \\
\hline $241-\mathrm{BX}-112$ & $\mathrm{GA}$ & 24 & 24 & $1.90 \mathrm{E}-01$ & $1.90 \mathrm{E}-01$ & $1.90 \mathrm{E}-01$ \\
\hline 241-BY-101 & $\mathrm{GA}$ & 4 & 2 & $2.24 \mathrm{E}-03$ & $2.32 \mathrm{E}-03$ & $1.12 \mathrm{E}-03$ \\
\hline $241-\mathrm{BY}-102$ & $\mathrm{GA}$ & 20 & 17 & $1.10 \mathrm{E}-01$ & $9.36 \mathrm{E}-02$ & $9.32 \mathrm{E}-02$ \\
\hline 241-BY-103 & GA & 4 & 2 & $2.35 \mathrm{E}-02$ & $1.35 \mathrm{E}-02$ & $1.18 \mathrm{E}-02$ \\
\hline 241-BY-104 & $\mathrm{GA}$ & 30 & 24 & $1.13 \mathrm{E}-01$ & $1.08 \mathrm{E}-01$ & $9.01 \mathrm{E}-02$ \\
\hline 241-BY-105 & GA & 62 & 24 & $1.04 \mathrm{E}-01$ & $1.68 \mathrm{E}-01$ & $4.03 \mathrm{E}-02$ \\
\hline 241-BY-106 & $\mathrm{GA}$ & 38 & 32 & $2.59 \mathrm{E}-02$ & $2.23 \mathrm{E}-02$ & $2.18 \mathrm{E}-02$ \\
\hline $241-\mathrm{BY}-107$ & $\mathrm{GA}$ & 34 & 25 & $4.68 \mathrm{E}-02$ & $3.80 \mathrm{E}-02$ & $3.44 \mathrm{E}-02$ \\
\hline
\end{tabular}

A-3 
HNF-4534 Rev. 1

Table A-2. Mean Alpha Concentration $(\mu \mathrm{Ci} / \mathrm{g}), \mathrm{SST}$ Solid Samples (3 sheets)

\begin{tabular}{|c|c|c|c|c|c|c|}
\hline . & snaye & Hning & 湤 & 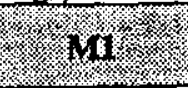 & אy & 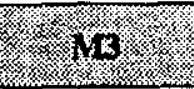 \\
\hline 241-BY-108 & GA & 56 & 40 & $8.66 \mathrm{E}-02$ & $6.37 \mathrm{E}-02$ & $6.19 \mathrm{E}-02$ \\
\hline $241-B Y-109$ & GA & 26 & 25 & $7.24 \mathrm{E}-02$ & $7.11 \mathrm{E}-02$ & $6.97 \mathrm{E}-02$ \\
\hline $241-B Y-110$ & $\mathrm{GA}$ & 110 & 101 & $5.38 \mathrm{E}-02$ & $5.09 \mathrm{E}-02$ & $4.94 \mathrm{E}-02$ \\
\hline $241-\mathrm{BY}-111$ & GA & 26 & 21 & $6.01 E-02$ & $1.06 \mathrm{E}-01$ & $4.85 \mathrm{E}-02$ \\
\hline $241-\mathrm{BY}-112$ & GA & 24 & 24 & $7.46 \mathrm{E}-02$ & $7.46 \mathrm{E}-02$ & $7.46 \mathrm{E}-02$ \\
\hline $241-C-101$ & $\mathrm{GA}$ & 6 & 6 & $1.09 \mathrm{E}+00$ & $1.09 \mathrm{E}+00$ & $1.09 \mathrm{E}+00$ \\
\hline $241-C-103$ & GA & 14 & 14 & $1.14 \mathrm{E}+01$ & $1.14 \mathrm{E}+01$ & $1.14 \mathrm{E}+01$ \\
\hline $241-C-104$ & GA & 28 & 28 & $6.37 \mathrm{E}+00$ & $6.37 \mathrm{E}+00$ & $6.37 \mathrm{E}+00$ \\
\hline 241-C-105 & GA & 16 & 16 & $1.33 E+00$ & $1.33 \mathrm{E}+00$ & $1.33 \mathrm{E}+00$ \\
\hline $241-C-106$ & GA & 22 & 22 & $2.77 \mathrm{E}+00$ & $2.77 \mathrm{E}+00$ & $2.77 \mathrm{E}+00$ \\
\hline $241-C-107$ & GA & 40 & 37 & $4.22 \mathrm{E}+00$ & $3.93 \mathrm{E}+00$ & $3.91 \mathrm{E}+00$ \\
\hline $241-C-108$ & GA & 22 & 2 & $7.81 \mathrm{E}-02$ & $1.50 \mathrm{E}-01$ & $7.10 \mathrm{E}-03$ \\
\hline $241-C-109$ & $\mathrm{GA}$ & 8 & 8 & $1.72 \mathrm{E}-01$ & $1.72 \mathrm{E}-01$ & $1.72 \mathrm{E}-01$ \\
\hline $241-C-110$ & $\mathrm{GA}$ & 18 & 18 & $1.25 \mathrm{E}-01$ & $1.25 \mathrm{E}-01$ & $1.25 \mathrm{E}-01$ \\
\hline $241-C-111$ & $\mathrm{GA}$ & 10 & 10 & $8.21 \mathrm{E}-01$ & $8.21 \mathrm{E}-01$ & $8.21 \mathrm{E}-01$ \\
\hline $241-\mathrm{C}-112$ & GA & 11 & 11 & $3.35 \mathrm{E}-01$ & 3.35E-01 & 3.35E-01 \\
\hline $241-C-202$ & GA & 4 & 4 & $8.64 \mathrm{E}+00$ & $8.64 \mathrm{E}+00$ & $8.64 \mathrm{E}+00$ \\
\hline $241-C-203$ & $\mathrm{GA}$ & 12 & 12 & $1.44 \mathrm{E}+\infty 0$ & $1.44 \mathrm{E}+00$ & $1.44 \mathrm{E}+00$ \\
\hline $241-C-204$ & $\mathrm{GA}$ & 6 & 6 & $2.66 \mathrm{E}-02$ & $2.66 \mathrm{E}-02$ & $2.66 \mathrm{E}-02$ \\
\hline $241-S-101$ & $\mathrm{GA}$ & 34 & 34 & $3.49 \mathrm{E}-01$ & $3.49 \mathrm{E}-01$ & $3.49 \mathrm{E}-01$ \\
\hline $241-S-102$ & $\overline{G A}$ & 90 & 89 & $1.78 \mathrm{E}-01$ & $1.77 \mathrm{E}-01$ & $1.76 \mathrm{E}-01$ \\
\hline $241-S-104$ & $\mathrm{GA}$ & 24 & 21 & $5.52 \mathrm{E}-01$ & $5.41 \mathrm{E}-01$ & $4.83 \mathrm{E}-01$ \\
\hline $241-S-106$ & $\mathrm{GA}$ & 20 & 18 & $3.09 \mathrm{E}-02$ & $2.88 \mathrm{E}-02$ & $2.78 \mathrm{E}-02$ \\
\hline $241-S-107$ & GA & 92 & 92 & $9.24 \mathrm{E}-01$ & $9.24 \mathrm{E}-01$ & $9.24 \mathrm{E}-01$ \\
\hline $241-S-109$ & $\mathrm{GA}$ & 30 & 27 & $7.74 \mathrm{E}-03$ & $7.39 \mathrm{E}-03$ & $6.97 \mathrm{E}-03$ \\
\hline $241-S-110$ & $\mathrm{GA}$ & 46 & 42 & $3.12 \mathrm{E}-01$ & $2.94 \mathrm{E}-01$ & $2.85 \mathrm{E}-01$ \\
\hline $241-S-111$ & $\mathrm{GA}$ & 34 & 28 & $3.46 \mathrm{E}-02$ & $2.89 \mathrm{E}-02$ & $2.85 \mathrm{E}-02$ \\
\hline $241-5 X-101$ & $\mathrm{GA}$ & 26 & 22 & $4.85 \mathrm{E}-01$ & 4.37E-01 & $4.11 \mathrm{E}-01$ \\
\hline $241-S X-102$ & GA & 38 & 34 & $2.13 \mathrm{E}-01$ & $1.92 \mathrm{E}-01$ & 1.91E-01 \\
\hline $241-S X-103$ & $\mathbf{G A}$ & 50 & 49 & $1.71 \mathrm{E}-01$ & $1.68 \mathrm{E}-01$ & $1.68 \mathrm{E}-01$ \\
\hline $241-S X-104$ & ${ }^{241} \mathrm{Am}$ & 4 & 0 & NA & $8.95 \mathrm{E}-02$ & $0.00 \mathrm{E}+00$ \\
\hline $241-S X-105$ & $\mathrm{GA}$ & 60 & 55 & $5.37 \mathrm{E}-01$ & $5.00 \mathrm{E}-01$ & $4.93 \mathrm{E}-01$ \\
\hline 241-SX-106 & $\mathrm{GA}$ & 30 & 19 & 4.35E-01 & $2.80 \mathrm{E}-01$ & $2.75 \mathrm{E}-01$ \\
\hline $241-5 X-108$ & GA & 8 & 8 & $3.29 \mathrm{E}+00$ & $3.29 \mathrm{E}+00$ & $3.29 \mathrm{E}+00$ \\
\hline $241-S X-113$ & $\mathrm{GA}$ & 8 & 5 & $1.42 \mathrm{E}-01$ & $1.69 \mathrm{E}-01$ & $8.85 \mathrm{E}-02$ \\
\hline $241-\$ X-115$ & ${ }^{241} \mathrm{Am}$ & 2 & 2 & $1.41 \mathrm{E}+01$ & $1.41 \mathrm{E}+01$ & $1.41 \mathrm{E}+01$ \\
\hline $241-T-102$ & GA & 2 & 2 & $2.29 \mathrm{E}-01$ & $2.29 \mathrm{E}-01$ & $2.29 \mathrm{E}-01$ \\
\hline $241-T-104$ & $\mathrm{GA}$ & 12 & 12 & $1.41 \mathrm{E}-01$ & $1.41 \mathrm{E}-01$ & $1.41 E-01$ \\
\hline $241-T-105$ & $\mathrm{GA}$ & 16 & 16 & $3.57 \mathrm{E}-01$ & $3.57 \mathrm{E}-01$ & $3.57 \mathrm{E}-01$ \\
\hline $241-\mathrm{T}-106$ & $\mathrm{GA}$ & 4 & 4 & $2.03 \mathrm{E}-01$ & $2.03 \mathrm{E}-01$ & 2.03E-01 \\
\hline
\end{tabular}

A-4 
HNF-4534 Rev. 1

Table A-2. Mean Alpha Concentration $(\mu \mathrm{Ci} / g)$, SST Solid Samples (3 sheets)

\begin{tabular}{|c|c|c|c|c|c|c|}
\hline in & indits & Nung obs & $\begin{array}{l}\text { Num, } \\
\text { Above BI }\end{array}$ & (2) & 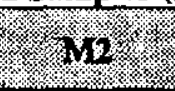 & 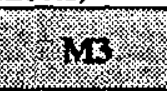 \\
\hline $241-T-107$ & $\mathrm{GA}$ & 10 & 10 & $1.77 \mathrm{E}-01$ & 1.T7E-01 & $1.77 \mathrm{E}-01$ \\
\hline $241-\mathrm{T}-108$ & $\mathrm{GA}$ & 4 & 4 & $7.02 \mathrm{E}-02$ & $7.02 \mathrm{E}-02$ & $7.02 \mathrm{E}-02$ \\
\hline $241-T-109$ & GA & 6 & 6 & $1.14 \mathrm{E}-02$ & $1.14 \mathrm{E}-02$ & $1.14 \mathrm{E}-02$ \\
\hline $241-T-110$ & GA & 30 & 30 & $5.31 \mathrm{E}-02$ & $5.31 \mathrm{E}-02$ & $5.31 \mathrm{E}-02$ \\
\hline $241-T-111$ & GA & 30 & 30 & $3.71 \mathrm{E}-01$ & $3.71 \mathrm{E}-01$ & $3.71 \mathrm{E}-01$ \\
\hline $241-\mathrm{T}-112$ & GA & 4 & 4 & $2.56 \mathrm{E}-01$ & $2.56 \mathrm{E}-01$ & $2.56 \mathrm{E}-01$ \\
\hline $241-T-201$ & GA & 6 & 6 & $7.57 \mathrm{E}-01$ & $7.57 \mathrm{E}-01$ & $7.57 \mathrm{E}-01$ \\
\hline $241-T-202$ & $\mathrm{GA}$ & 10 & 10 & $2.22 \mathrm{E}-01$ & $2.22 \mathrm{E}-01$ & $2.22 \mathrm{E}-01$ \\
\hline $241-\mathrm{T}-203$ & GA & 20 & 20 & $1.96 \mathrm{E}-01$ & $1.96 \mathrm{E}-01$ & $1.96 \mathrm{E}-01$ \\
\hline $241-\mathrm{T}-204$ & GA & 20 & 19 & $1.52 \mathrm{E}-01$ & $1.44 \mathrm{E}-01$ & $1.44 \mathrm{E}-01$ \\
\hline $241-\mathrm{TX}-104$ & $\mathrm{GA}$ & 12 & 12 & $3.09 \mathrm{E}-01$ & $3.09 \mathrm{E}-01$ & $3.09 \mathrm{E}-01$ \\
\hline $241-T X-107$ & $\mathrm{GA}$ & 4 & 4 & $4.52 \mathrm{E}+00$ & $4.52 \mathrm{E}+00$ & $4.52 \mathrm{E}+00$ \\
\hline $241-\mathrm{TX}-113$ & $\mathrm{GA}$ & 38 & 35 & $1.30 \mathrm{E}-02$ & $1.37 \mathrm{E}-02$ & $1.20 \mathrm{E}-02$ \\
\hline $241-\mathrm{TX}-118$ & $\mathrm{GA}$ & 33 & 29 & $2.28 \mathrm{E}+01$ & $2.00 \mathrm{E}+01$ & $2.00 \mathrm{E}+01$ \\
\hline $241-T Y-104$ & $\mathrm{GA}$ & 4 & 4 & $1.45 \mathrm{E}-01$ & $1.45 \mathrm{E}-01$ & $1.45 \mathrm{E}-01$ \\
\hline $241-\mathrm{TY}-106$ & GA & 6 & 3 & $1.96 \mathrm{E}-02$ & $1.83 \mathrm{E}-02$ & $9.78 \mathrm{E}-03$ \\
\hline $241-U-101$ & GA & 5 & 4 & $7.44 \mathrm{E}-02$ & $7.27 \mathrm{E}-02$ & $5.95 \mathrm{E}-02$ \\
\hline $241-U-102$ & $\mathrm{GA}$ & 32 & 32 & $2.05 \mathrm{E}-01$ & $2.05 \mathrm{E}-0 \mathrm{I}$ & $2.05 \mathrm{E}-01$ \\
\hline $241-\mathrm{U}-103$ & $\mathrm{GA}$ & 56 & 52 & $1.48 \mathrm{E}-01$ & $1.40 \mathrm{E}-01$ & $1.37 \mathrm{E}-01$ \\
\hline $241-U-105$ & $\mathrm{GA}$ & 58 & 58 & $7.23 \mathrm{E}-01$ & $7.23 \mathrm{E}-01$ & $7.23 \mathrm{E}-01$ \\
\hline $241-U-106$ & $\mathrm{GA}$ & 18 & 18 & $1.15 \mathrm{E}+\infty 0$ & $1.15 E+00$ & $1.15 \mathrm{E}+00$ \\
\hline $241-U-107$ & $\mathrm{GA}$ & 70 & 63 & $2.19 \mathrm{E}-01$ & $2.12 \mathrm{E}-01$ & $1.97 \mathrm{E}-01$ \\
\hline $241-U-108$ & $\mathrm{GA}$ & 106 & 100 & $5.25 \mathrm{E}-02$ & $5.31 \mathrm{E}-02$ & $4.96 \mathrm{E}-02$ \\
\hline $241-U-109$ & $\mathrm{GA}$ & 92 & 90 & $3.71 \mathrm{E}-02$ & $4.07 \mathrm{E}-02$ & $3.63 E-02$ \\
\hline $241-\mathrm{U}-110$ & $\overline{G A}$ & 82 & 47 & $7.47 \mathrm{E}-01$ & $5.96 \mathrm{E}-01$ & $4.28 \mathrm{E}-01$ \\
\hline $241-\mathrm{U}-112$ & $\overline{G A}$ & 4 & 0 & NA & $3.29 \mathrm{E}-03$ & $0.00 \mathrm{E}+00$ \\
\hline $241-U-201$ & $\mathrm{GA}$ & 12 & 0 & NA & $1.69 \mathrm{E}-03$ & $0.00 \mathrm{E}+00$ \\
\hline $241-U-202$ & GA & 14 & 4 & $1.26 \mathrm{E}-03$ & $1.73 \mathrm{E}-03$ & $3.59 \mathrm{E}-04$ \\
\hline $241-U-203$ & $\mathrm{GA}$ & 6 & 1 & $9.75 \mathrm{E}-04$ & $1.27 \mathrm{E}-03$ & $1.63 \mathrm{E}-04$ \\
\hline $241-U-204$ & GA & 4 & 1 & $9.67 \mathrm{E}-02$ & $6.17 \mathrm{E}-02$ & $2.42 \mathrm{E}-02$ \\
\hline
\end{tabular}


HNF-4534 Rev. 1

Table A-3. Mean ${ }^{m / 90} \mathrm{Sr}$ Concentration $(\mu \mathrm{Ci} / \mathrm{g})$, SST Solid Samples (2 sheets)

\begin{tabular}{|c|c|c|c|c|c|c|}
\hline 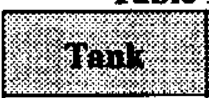 & hingle & Hing ow & 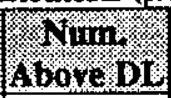 & in & (in) & 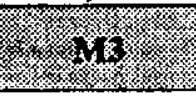 \\
\hline $241-\mathrm{A}-101$ & ${ }^{89900} \mathrm{Sr}$ & 8 & 8 & $1.55 \mathrm{E}+01$ & $1.55 \mathrm{E}+01$ & $1.55 \mathrm{E}+01$ \\
\hline $241-\mathrm{AX}-101$ & ${ }^{89190} \mathrm{Sr}$ & 22 & 22 & $1.82 \mathrm{E}+01$ & $1.82 \mathrm{E}+01$ & $1.82 \mathrm{E}+01$ \\
\hline $241-\mathrm{AX}-104$ & ${ }^{89190} \mathrm{Sr}$ & 20 & 20 & $1.88 \mathrm{E}+04$ & $1.88 \mathrm{E}+04$ & $1.88 \mathrm{E}+04$ \\
\hline $241-\mathrm{B}-106$ & ${ }^{89190} \mathrm{Sr}$ & 20 & 20 & $7.18 \mathrm{E}+01$ & $7.18 \mathrm{E}+01$ & $7.18 \mathrm{E}+01$ \\
\hline $241-B-108$ & ${ }^{191900} \mathrm{Sr}$ & 8 & 8 & $2.87 \mathrm{E}+00$ & $2.87 \mathrm{E}+00$ & $2.87 \mathrm{E}+00$ \\
\hline $241-\mathrm{B}-110$ & ${ }^{90} \mathrm{Sr}$ & 6 & 6 & $3.23 \mathrm{E}+01$ & $3.23 \mathrm{E}+01$ & $3.23 \mathrm{E}+01$ \\
\hline $241-B-111$ & ${ }^{90} \mathrm{Sr}$ & 8 & 8 & $2.48 \mathrm{E}+02$ & $2.48 \mathrm{E}+02$ & $2.48 \mathrm{E}+02$ \\
\hline $241-\mathrm{B}-201$ & ${ }^{90} \mathrm{Sr}$ & 6 & 6 & $2.70 \mathrm{E}+00$ & $2.70 \mathrm{E}+00$ & $2.70 \mathrm{E}+00$ \\
\hline $241-\mathrm{B}-202$ & ${ }^{90} \mathrm{Sr}$ & 10 & 10 & $3.99 \mathrm{E}+00$ & $3.99 \mathrm{E}+00$ & $3.99 E+00$ \\
\hline 241-BX-107 & ${ }^{90} \mathrm{Sr}$ & 8 & 8 & $9.87 \mathrm{E}+00$ & $9.87 \mathrm{E}+00$ & $9.87 \mathrm{E}+00$ \\
\hline 241-BX-109 & ${ }^{8990} \mathrm{Sr}$ & 6 & 6 & $1.62 \mathrm{E}+02$ & $1.62 \mathrm{E}+02$ & $1.62 \mathrm{E}+02$ \\
\hline 241-BX-112 & ${ }^{90} \mathrm{Sr}$ & 12 & 12 & $6.17 \mathrm{E}+\infty 0$ & $6.17 \mathrm{E}+00$ & $6.17 \mathrm{E}+00$ \\
\hline 241-BY-104 & ${ }^{89190} \mathrm{Sr}$ & 48 & 48 & $1.84 \mathrm{E}+02$ & $1.84 \mathrm{E}+02$ & $1.84 \mathrm{E}+02$ \\
\hline 241-BY-105 & ${ }^{8990} \mathrm{Sr}$ & 44 & 44 & $1.26 \mathrm{E}+02$ & $1.26 \mathrm{E}+02$ & $1.26 \mathrm{E}+02$ \\
\hline 241-BY-106 & ${ }^{89990} \mathrm{Sr}$ & 68 & 68 & $2.67 \mathrm{E}+01$ & $2.67 \mathrm{E}+01$ & $2.67 \mathrm{E}+01$ \\
\hline 241-BY-107 & ${ }^{89100} \mathrm{Sr}$ & 8 & 8 & $2.21 \mathrm{E}+01$ & $2.21 E+01$ & $2.21 \mathrm{E}+01$ \\
\hline $241-\mathrm{BY}-110$ & ${ }^{89900} \mathrm{Sr}$ & 216 & 216 & $1.08 \mathrm{E}+02$ & $1.08 \mathrm{E}+02$ & $1.08 \mathrm{E}+02$ \\
\hline $241-\mathrm{C}-103$ & ${ }^{89} \times 100 \mathrm{Sr}$ & 10 & 10 & $4.90 \mathrm{E}+03$ & $4.90 \mathrm{E}+03$ & $4.90 \mathrm{E}+03$ \\
\hline $241-C-104$ & ${ }^{89190} \mathrm{Sr}$ & 4 & 4 & $3.23 E+02$ & $3.23 \mathrm{E}+02$ & $3.23 \mathrm{E}+02$ \\
\hline $241-C-106$ & ${ }^{899190} \mathrm{Sr}$ & 22 & 22 & $5.17 \mathrm{E}+02$ & $5.17 \mathrm{E}+02$ & $5.17 \mathrm{E}+02$ \\
\hline $241-\mathrm{C}-107$ & ${ }^{89 / 90} \mathrm{Sr}$ & 12 & 12 & $2.81 E+03$ & $2.81 E+03$ & $2.81 E+03$ \\
\hline $241-C-108$ & ${ }^{89900} \mathrm{Sr}$ & 20 & 20 & $1.95 \mathrm{E}+02$ & $1.95 \mathrm{E}+02$ & $1.95 \mathrm{E}+02$ \\
\hline $241-\mathrm{C}-109$ & ${ }^{90} \mathrm{Sr}$ & 11 & 11 & $9.58 \mathrm{E}+02$ & $9.58 \mathrm{E}+02$ & $9.58 \mathrm{E}+02$ \\
\hline $241-C-110$ & ${ }^{90} \mathrm{Sr}$ & 10 & 10 & $5.04 \mathrm{E}+00$ & $5.04 \mathrm{E}+00$ & $5.04 \mathrm{E}+00$ \\
\hline $241-C-111$ & ${ }^{90} \mathrm{SI}$ & 4 & 4 & $4.21 \mathrm{E}+03$ & $4.21 \mathrm{E}+03$ & $4.21 \mathrm{E}+03$ \\
\hline $241-\mathrm{C}-112$ & ${ }^{90} \mathrm{Sr}$ & 25 & 25 & $1.29 \mathrm{E}+03$ & $1.29 \mathrm{E}+03$ & $1.29 E+03$ \\
\hline $241-S-101$ & ${ }^{8990} \mathrm{ST}$ & 4 & 4 & $2.52 \mathrm{E}+02$ & $2.52 \mathrm{E}+02$ & $2.52 \mathrm{E}+02$ \\
\hline $241-S-102$ & ${ }^{891900} \mathrm{Sr}$ & 24 & 24 & $2.54 \mathrm{E}+01$ & $2.54 \mathrm{E}+01$ & $2.54 \mathrm{E}+01$ \\
\hline $241-S-104$ & ${ }^{90} \mathrm{Sr}$ & 12 & 12 & $3.10 \mathrm{E}+02$ & $3.10 \mathrm{E}+02$ & $3.10 \mathrm{E}+02$ \\
\hline $241-S-106$ & ${ }^{89900} \mathrm{Sr}$ & 4 & 4 & $1.49 \mathrm{E}+01$ & $1.49 \mathrm{E}+01$ & $1.49 \mathrm{E}+01$ \\
\hline $241-S-107$ & ${ }^{8990} \mathrm{Sr}$ & 92 & 92 & $1.60 \mathrm{E}+02$ & $1.60 \mathrm{E}+02$ & $1.60 \mathrm{E}+02$ \\
\hline $241-S-109$ & ${ }^{89990} \mathrm{Sr}$ & 4 & 4 & $5.31 \mathrm{E}+00$ & $5.31 \mathrm{E}+00$ & $5.31 \mathrm{E}+00$ \\
\hline $241-S-110$ & ${ }^{899190} \mathrm{Sr}$ & 62 & 62 & $1.22 \mathrm{E}+02$ & $1.22 \mathrm{E}+02$ & $1.22 \mathrm{E}+02$ \\
\hline $241-S-111$ & ${ }^{8990} \mathrm{Sr}$ & 16 & 16 & $1.21 \mathrm{E}+02$ & $1.21 \mathrm{E}+02$ & $1.21 \mathrm{E}+02$ \\
\hline $241-S X-101$ & ${ }^{89 / 90} \mathrm{Sr}$ & 4 & 4 & $1.20 \mathrm{E}+02$ & $1.20 \mathrm{E}+02$ & $1.20 \mathrm{E}+02$ \\
\hline $241-S X-102$ & ${ }^{89190} \mathrm{Sr}$ & 4 & 4 & $1.03 \mathrm{E}+02$ & $1.03 \mathrm{E}+02$ & $1.03 \mathrm{E}+02$ \\
\hline 241-SX-103 & ${ }^{89990} \mathrm{Sr}$ & 54 & 54 & $1.29 \mathrm{E}+02$ & $1.29 \mathrm{E}+02$ & $1.29 E+02$ \\
\hline $241-S X-104$ & ${ }^{8990} \mathrm{Sr}$ & 2 & 2 & $1.47 \mathrm{E}-01$ & $1.47 \mathrm{E}-01$ & $1.47 \mathrm{E}-01$ \\
\hline $241-S X-108$ & ${ }^{89 / 90} \mathrm{Sr}$ & 8 & 8 & $3.06 \mathrm{E}+03$ & $3.06 \mathrm{E}+03$ & $3.06 \mathrm{E}+03$ \\
\hline
\end{tabular}

A-6 
HNF-4534 Rev. 1

Table A-3. Mean ${ }^{8900} \mathrm{Sr}$ Concentration $(\mu \mathrm{Ci} / \mathrm{g})$, SST Solid Samples (2 sheets)

\begin{tabular}{|c|c|c|c|c|c|c|}
\hline (. & inilyte & Sinirobs & 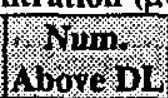 & . 11 & (2) & $l^{2}$ \\
\hline $241-T-102$ & ${ }^{90} \mathrm{Sr}$ & 2 & 2 & $2.38 \mathrm{E}+02$ & $2.38 \mathrm{E}+02$ & $2.38 \mathrm{E}+02$ \\
\hline 241-T-104 & ${ }^{90} \mathrm{Sr}$ & 8 & 8 & $2.63 \mathrm{E}+00$ & $2.63 \mathrm{E}+00$ & $2.63 \mathrm{E}+00$ \\
\hline $241-\mathrm{T}-105$ & ${ }^{90} \mathrm{Sr}$ & 4 & 4 & $2.80 \mathrm{E}+02$ & $2.80 \mathrm{E}+02$ & $2.80 \mathrm{E}+02$ \\
\hline $241-\mathrm{T}-107$ & ${ }^{90} \mathrm{~S} r$ & 30 & 30 & $1.20 \mathrm{E}+02$ & $1.20 E+02$ & $1.20 \mathrm{E}+02$ \\
\hline $241-\mathrm{T}-111$ & ${ }^{90} \mathrm{Sr}$ & 8 & 8 & $5.41 \mathrm{E}+00$ & $5.41 \mathrm{E}+00$ & $5.41 \mathrm{E}+00$ \\
\hline $241-\mathrm{T}-201$ & ${ }^{8900} \mathrm{Sr}$ & 4 & 4 & $8.58 \mathrm{E}-02$ & $8.58 \mathrm{E}-02$ & $8.58 \mathrm{E}-02$ \\
\hline $241-\mathrm{T}-202$ & ${ }^{8990} \mathrm{Sr}$ & 2 & 2 & $2.49 \mathrm{E}-03$ & $2.49 \mathrm{E}-03$ & $2.49 \mathrm{E}-03$ \\
\hline $241-T-203$ & ${ }^{89190} \mathrm{Sr}$ & 2 & 2 & $2.57 \mathrm{E}-03$ & $2.57 \mathrm{E}-03$ & $2.57 \mathrm{E}-03$ \\
\hline $241-\mathrm{T}-204$ & ${ }^{891000} \mathrm{Sr}$ & 2 & 2 & $4.60 \mathrm{E}-03$ & $4.60 \mathrm{E}-03$ & $4.60 \mathrm{E}-03$ \\
\hline $241-\mathrm{TX}-113$ & ${ }^{8990} \mathrm{Sr}$ & 16 & 16 & $1.07 \mathrm{E}+00$ & $1.07 \mathrm{E}+00$ & $1.07 \mathrm{E}+\infty 0$ \\
\hline $241-\mathrm{TX}-118$ & ${ }^{8990} \mathrm{Sr}$ & 10 & 10 & $1.83 \mathrm{E}+02$ & $1.83 \mathrm{E}+02$ & $1.83 \mathrm{E}+02$ \\
\hline $241-\mathrm{U}-102$ & ${ }^{89190} \mathrm{Sr}$ & 6 & 6 & $5.51 \mathrm{E}+01$ & $5.51 \mathrm{E}+01$ & $5.51 \mathrm{E}+01$ \\
\hline $241-U-103$ & ${ }^{8980} \mathrm{Sr}$ & 6 & 6 & $1.01 \mathrm{E}+01$ & $1.01 \mathrm{E}+01$ & $1.01 E+01$ \\
\hline $241-U-105$ & ${ }^{8990} \mathrm{Sr}$ & 8 & 8 & $5.71 \mathrm{E}+01$ & $5.71 \mathrm{E}+01$ & $5.71 E+01$ \\
\hline $241-\mathrm{U}-106$ & ${ }^{89909} \mathrm{Sr}$ & 4 & 4 & $7.72 \mathrm{E}+01$ & $7.72 \mathrm{E}+01$ & $7.72 \mathrm{E}+01$ \\
\hline $241-\mathrm{U}-107$ & ${ }^{8990} \mathrm{Sr}$ & 10 & 10 & $4.34 \mathrm{E}+00$ & $4.34 \mathrm{E}+00$ & $4.34 \mathrm{E}+00$ \\
\hline $241-U-108$ & ${ }^{8990} \mathrm{SI}$ & 106 & 106 & $1.03 E+01$ & $1.03 \mathrm{E}+01$ & $1.03 \mathrm{E}+01$ \\
\hline $241-U-109$ & ${ }^{89900} \mathrm{Sr}$ & 32 & 32 & $8.81 E+00$ & $8.81 E+00$ & $8.81 \mathrm{E}+00$ \\
\hline $241-U-110$ & ${ }^{8990} \mathrm{Sr} \&^{90} \mathrm{Sr}$ & 30 & 28 & $1.57 \mathrm{E}+02$ & $1.47 \mathrm{E}+02$ & $1.47 \mathrm{E}+02$ \\
\hline
\end{tabular}

A-7 
HNF-4534 Rev. 1

Table A-4. Mean ${ }^{137} \mathrm{Cs}$ Concentration $(\mu \mathrm{Ci} / \mathrm{g})$, SST Liquid Samples

\begin{tabular}{|c|c|c|c|c|c|c|}
\hline rant & dinalyte & Thim obs & A rove Di. & $\mathbf{M i}$ & 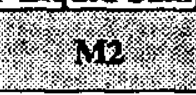 & $\mathrm{s}^{2}$ \\
\hline $241-\mathrm{A}-101$ & ${ }^{137} \mathrm{Cs}$ & 16 & 16 & $3.53 \mathrm{E}+05$ & $3.53 \mathrm{E}+05$ & $3.53 \mathrm{E}+05$ \\
\hline $241-\mathrm{AX}-101$ & ${ }^{137} \mathrm{Cs}$ & 6 & 6 & $3.95 \mathrm{E}+05$ & $3.95 \mathrm{E}+05$ & $3.95 \mathrm{E}+05$ \\
\hline 241-BX-109 & ${ }^{837} \mathrm{Cs}$ & 4 & 2 & $1.27 \mathrm{E}+04$ & $6.33 \mathrm{E}+03$ & $6.33 \mathrm{E}+03$ \\
\hline $241-\mathrm{BY}-103$ & ${ }^{37} \mathrm{Cs}$ & 4 & 4 & $1.41 E+05$ & $1.41 \mathrm{E}+05$ & $1.41 \mathrm{E}+05$ \\
\hline 241-BY-105 & ${ }^{137} \mathrm{Cs}$ & 42 & 42 & $1.99 \mathrm{E}+05$ & $1.99 \mathrm{E}+05$ & $1.99 \mathrm{E}+05$ \\
\hline 241-BY-106 & ${ }^{137} \mathrm{Cs}$ & 6 & 6 & $2.07 \mathrm{E}+05$ & $2.07 \mathrm{E}+05$ & $2.07 \mathrm{E}+05$ \\
\hline $241-C-106$ & ${ }^{137} \mathrm{Cs}$ & 18 & 18 & $1.25 \mathrm{E}+05$ & $1.25 \mathrm{E}+05$ & $1.25 \mathrm{E}+05$ \\
\hline $241-C-110$ & ${ }^{137} \mathrm{Cs}$ & 6 & 6 & $3.88 \mathrm{E}+03$ & $3.88 \mathrm{E}+03$ & $3.88 \mathrm{E}+03$ \\
\hline $241-S-102$ & ${ }^{137} \mathrm{Cs}$ & 6 & 6 & $3.24 \mathrm{E}+05$ & $3.24 \mathrm{E}+05$ & $3.24 \mathrm{E}+05$ \\
\hline $241-S-103$ & ${ }^{197} \mathrm{Cs}$ & 6 & 6 & $3.65 \mathrm{E}+05$ & $3.65 \mathrm{E}+05$ & $3.65 \mathrm{E}+05$ \\
\hline $241-S-106$ & ${ }^{137} \mathrm{Cs}$ & 16 & 16 & $2.67 \mathrm{E}+05$ & $2.67 \mathrm{E}+05$ & $2.67 \mathrm{E}+05$ \\
\hline $241-S-109$ & ${ }^{137} \mathrm{Cs}$ & 6 & 6 & $3.15 \mathrm{E}+05$ & $3.15 \mathrm{E}+05$ & $3.15 E+05$ \\
\hline $241-S-111$ & ${ }^{137} \mathrm{Cs}$ & 16 & 16 & $2.75 \mathrm{E}+05$ & $2.75 \mathrm{E}+05$ & $2.75 \mathrm{E}+05$ \\
\hline $241-S X-101$ & ${ }^{137} \mathrm{Cs}$ & 20 & 20 & $4.03 \mathrm{E}+05$ & $4.03 \mathrm{E}+05$ & $4.03 E+05$ \\
\hline $241-\mathrm{SX}-102$ & ${ }^{137} \mathrm{Cs}$ & 2 & 2 & $4.38 \mathrm{E}+05$ & $4.38 \mathrm{E}+05$ & $4.38 \mathrm{E}+05$ \\
\hline $241-S X-103$ & ${ }^{137} \mathrm{Cs}$ & 6 & 6 & $4.40 \mathrm{E}+05$ & $4.40 \mathrm{E}+05$ & $4.40 \mathrm{E}+05$ \\
\hline $241-S X-104$ & ${ }^{137} \mathrm{Cs}$ & 2 & 2 & $2.83 \mathrm{E}+05$ & $2.83 \mathrm{E}+05$ & $2.83 \mathrm{E}+05$ \\
\hline $241-S X-105$ & ${ }^{137} \mathrm{Cs}$ & 28 & 28 & $3.84 E+05$ & $3.84 \mathrm{E}+05$ & $3.84 \mathrm{E}+05$ \\
\hline $241-S X-106$ & ${ }^{137} \mathrm{Cs}$ & 16 & 16 & $3.77 \mathrm{E}+05$ & $3.77 \mathrm{E}+05$ & $3.77 \mathrm{E}+05$ \\
\hline $241-T-104$ & ${ }^{137} \mathrm{Cs}$ & 2 & 2 & $7.83 \mathrm{E}+01$ & $7.83 \mathrm{E}+01$ & $7.83 \mathrm{E}+01$ \\
\hline $241-\mathrm{T}-107$ & ${ }^{137} \mathrm{Cs}$ & 6 & 6 & $8.43 E+03$ & $8.43 \mathrm{E}+03$ & $8.43 \mathrm{E}+03$ \\
\hline $241-T$ & ${ }^{137} \mathrm{Cs}$ & 3 & 3 & $3.43 \mathrm{E}+00$ & $3.43 E+00$ & $3.43 E+00$ \\
\hline 241-U & ${ }^{137} \mathrm{Cs}$ & 10 & 10 & $4.36 \mathrm{E}+05$ & $4.36 \mathrm{E}+05$ & $4.36 \mathrm{E}+05$ \\
\hline $241-U-103$ & ${ }^{131} \mathrm{Cs}$ & 8 & 8 & $4.67 \mathrm{E}+05$ & $4.67 \mathrm{E}+05$ & $4.67 \mathrm{E}+05$ \\
\hline $241-U-105$ & ${ }^{137} \mathrm{Cs}$ & 6 & 6 & $3.86 \mathrm{E}+05$ & $3.86 \mathrm{E}+05$ & $3.86 \mathrm{E}+05$ \\
\hline $241-U-107$ & ${ }^{137} \mathrm{Cs}$ & 14 & 14 & $3.52 \mathrm{E}+0 \mathrm{5}$ & $3.52 \mathrm{E}+05$ & $3.52 \mathrm{E}+05$ \\
\hline $241-U-108$ & ${ }^{137} \mathrm{Cs}$ & 2 & 2 & $4.16 \mathrm{E}+05$ & $4.16 \mathrm{E}+05$ & $4.16 \mathrm{E}+05$ \\
\hline $241-\mathrm{U}-109$ & ${ }^{137} \mathrm{Cs}$ & 2 & 2 & $3.66 \mathrm{E}+05$ & $3.66 \mathrm{E}+05$ & $3.66 \mathrm{E}+05$ \\
\hline
\end{tabular}

A-8 
HNF-4534 Rev. 1

Table A-5. Mean Alpha Concentration ( $\mu \mathrm{Ci} / \mathrm{g}$ ), SST Liquid Samples (2 sheets)

\begin{tabular}{|c|c|c|c|c|c|c|}
\hline Tinil & Sulgte & Tringows & $\begin{array}{l}\text { Nom. } \\
\text { Above DI. }\end{array}$ & il & ng & 10 \\
\hline $241-\mathrm{A}-101$ & GA & 32 & 3 & $5.68 \mathrm{E}+00$ & $1.54 \mathrm{E}+01$ & $5.32 \mathrm{E}-01$ \\
\hline $241-\mathrm{AX}-101$ & $\overline{G A}$ & 24 & 0 & NA & $2.16 \mathrm{E}+01$ & $0.00 \mathrm{E}+00$ \\
\hline 241-B-107 & $\mathrm{GA}$ & 6 & 1 & $2.26 \mathrm{E}-01$ & $2.05 \mathrm{E}-01$ & $3.77 \mathrm{E}-02$ \\
\hline $241-\mathrm{B}-108$ & GA & 2 & 0 & NA & $3.95 \mathrm{E}+00$ & $0.00 \mathrm{E}+00$ \\
\hline $241-B-203$ & GA & 6 & 6 & $1.01 \mathrm{E}-01$ & $1.01 \mathrm{E}-01$ & $1.01 \mathrm{E}-01$ \\
\hline $241-\mathrm{B}-204$ & GA & 6 & 6 & $1.03 \mathrm{E}-01$ & $1.03 \mathrm{E}-01$ & $1.03 \mathrm{E}-01$ \\
\hline 241-BX-109 & GA & 4 & 3 & $4.40 \mathrm{E}-01$ & $3.48 \mathrm{E}-01$ & $3.30 \mathrm{E}-01$ \\
\hline $241-\mathrm{BX}-110$ & $\overline{\mathrm{GA}}$ & 12 & 1 & $5.01 \mathrm{E}+00$ & $5.51 \mathrm{E}+00$ & $4.18 \mathrm{E}-01$ \\
\hline $241-\mathrm{BX}-111$ & $\overline{G A}$ & 2 & 1 & $3.93 E+00$ & $3.79 \mathrm{E}+\infty 0$ & $1.97 \mathrm{E}+00$ \\
\hline $241-\mathrm{BY}-102$ & $\mathrm{GA}$ & 4 & 2 & $5.96 \mathrm{E}+00$ & $4.78 \mathrm{E}+\infty 0$ & $2.98 \mathrm{E}+\infty 0$ \\
\hline $241-\mathrm{BY}-103$ & ${ }^{24 i} \mathrm{Am}$ & 4 & 0 & $\mathrm{NA}$ & $6.90 \mathrm{E}-01$ & $0.00 \mathrm{E}+00$ \\
\hline 241-BY-105 & $\mathrm{GA}$ & 46 & 17 & $2.99 \mathrm{E}+01$ & $1.76 \mathrm{E}+01$ & $1.10 \mathrm{E}+01$ \\
\hline $241-\mathrm{BY}-106$ & GA & 2 & 0 & NA & $1.23 \mathrm{E}+01$ & $0.00 \mathrm{E}+00$ \\
\hline 241-BY-107 & $\mathrm{GA}$ & 18 & 0 & $\mathrm{NA}$ & $8.94 E+00$ & $0.00 \mathrm{E}+00$ \\
\hline $241-B Y-108$ & $\mathrm{GA}$ & 2 & 1 & $3.65 \mathrm{E}+00$ & $2.48 \mathrm{E}+00$ & $1.83 \mathrm{E}+00$ \\
\hline $241-\mathrm{BY}-109$ & $\mathrm{GA}$ & 4 & 1 & $1.14 \mathrm{E}+01$ & $1.49 \mathrm{E}+01$ & $2.85 \mathrm{E}+00$ \\
\hline $241-B Y-110$ & GA & 14 & 0 & NA & $1.81 \mathrm{E}+00$ & $0.00 \mathrm{E}+00$ \\
\hline $241-B Y-111$ & $\mathrm{GA}$ & 6 & 1 & $7.45 \mathrm{E}+00$ & $7.30 \mathrm{E}+00$ & $1.24 \mathrm{E}+00$ \\
\hline $241-B Y-112$ & $\mathrm{GA}$ & 4 & 0 & NA & $1.63 E+01$ & $0.00 \mathrm{E}+00$ \\
\hline $241-C-104$ & $\mathrm{GA}$ & 4 & 0 & $\mathrm{NA}$ & $1.27 \mathrm{E}+00$ & $0.00 \mathrm{E}+00$ \\
\hline $241-C-106$ & $\mathrm{GA}$ & 4 & 4 & $1.02 \mathrm{E}+03$ & $1.02 \mathrm{E}+03$ & $1.02 \mathrm{E}+03$ \\
\hline $241-C-110$ & GA & 6 & 2 & $2.07 \mathrm{E}+00$ & $1.11 \mathrm{E}+00$ & $6.90 \mathrm{E}-01$ \\
\hline $241-S-101$ & $\mathrm{GA}$ & 10 & 2 & $1.17 \mathrm{E}+01$ & $5.25 \mathrm{E}+00$ & $2.33 \mathrm{E}+00$ \\
\hline $241-S-102$ & $\mathrm{GA}$ & 10 & 1 & $1.21 \mathrm{E}+01$ & $1.22 \mathrm{E}+01$ & $1.21 \mathrm{E}+00$ \\
\hline $241-S-103$ & ${ }^{241} \mathrm{Am}$ & 6 & 6 & $1.19 \mathrm{E}+00$ & $1.19 \mathrm{E}+00$ & $1.19 E+00$ \\
\hline $241-S-104$ & $\mathrm{GA}$ & 1 & 1 & $1.88 \mathrm{E}+02$ & $1.88 \mathrm{E}+02$ & $1.88 \mathrm{E}+02$ \\
\hline $241-S-106$ & $G A$ & 18 & 7 & $2.20 \mathrm{E}+00$ & $5.86 \mathrm{E}+00$ & $8.54 \mathrm{E}-01$ \\
\hline $241-S-107$ & GA & 8 & 1 & $2.08 \mathrm{E}+00$ & $2.46 \mathrm{E}+00$ & $2.60 \mathrm{E}-01$ \\
\hline $241-S-109$ & GA & 8 & 3 & $6.12 \mathrm{E}+00$ & $1.02 \mathrm{E}+01$ & $2.29 \mathrm{E}+00$ \\
\hline $241-S-110$ & $\mathrm{GA}$ & 8 & 0 & $\mathrm{NA}$ & $9.12 \mathrm{E}+00$ & $0.00 \mathrm{E}+00$ \\
\hline $241-S-111$ & ${ }^{241} \mathrm{Am}$ & 18 & 10 & $1.76 \mathrm{E}-01$ & $2.13 \mathrm{E}+02$ & $9.76 \mathrm{E}-02$ \\
\hline $241-S X-101$ & $G A$ & 20 & 3 & $8.22 \mathrm{E}+02$ & $1.36 \mathrm{E}+02$ & $1.23 \mathrm{E}+02$ \\
\hline $241-S X-102$ & GA & 14 & 6 & $5.87 \mathrm{E}+00$ & $8.93 E+00$ & $2.51 \mathrm{E}+00$ \\
\hline $241-S X-103$ & $\mathrm{GA}$ & 24 & 8 & $1.24 \mathrm{E}+01$ & $1.66 \mathrm{E}+01$ & $4.12 \mathrm{E}+00$ \\
\hline $241-S X-104$ & ${ }^{241} \mathrm{Am}$ & 4 & 1 & $2.62 \mathrm{E}-02$ & $6.47 \mathrm{E}+02$ & $6.55 \mathrm{E}-03$ \\
\hline $241-S X-105$ & $\mathrm{GA}$ & 36 & 29 & $7.32 \mathrm{E}+00$ & $5.89 E+00$ & $5.89 \mathrm{E}+00$ \\
\hline $241-S X-106$ & $\mathrm{GA}$ & 10 & 3 & $4.11 E+00$ & $3.64 \mathrm{E}+00$ & $1.23 \mathrm{E}+00$ \\
\hline $241-\mathrm{T}-103$ & GA & 4 & 4 & $2.00 \mathrm{E}+01$ & $2.00 \mathrm{E}+01$ & $2.00 \mathrm{E}+01$ \\
\hline $241-T-104$ & ${ }^{241} \mathrm{Am}$ & 2 & 0 & NA & $9.53 \mathrm{E}-01$ & $0.00 \mathrm{E}+00$ \\
\hline
\end{tabular}

A -9 


\section{HNF-4534 Rev. 1}

Table A-5. Mean Alpha Concentration ( $\mu \mathrm{Ci} / \mathrm{g})$, SST Liquid Samples (2 sheets)

\begin{tabular}{|c|c|c|c|c|c|c|}
\hline (1) lail : & andorte & Nam Obs & Moum, & . & $n^{2}$ & 19 \\
\hline $241-T-105$ & GA & 8 & 4 & $1.54 \mathrm{E}+01$ & $9.02 E+00$ & $7.69 \mathrm{E}+00$ \\
\hline 241-T-107 & GA & 6 & 6 & $6.01 E+00$ & $6.01 E+00$ & $6.01 E+00$ \\
\hline $241-T-110$ & $\overrightarrow{G A}$ & 2 & 2 & $1.02 \mathrm{E}-01$ & $1.02 \mathrm{E}-01$ & $1.02 \mathrm{E}-01$ \\
\hline $24 \mathrm{I}-\mathrm{T}-112$ & GA & 4 & 4 & $2.33 \mathrm{E}+01$ & $2.33 \mathrm{E}+01$ & $2.33 \mathrm{E}+01$ \\
\hline $241-\mathrm{T}-201$ & GA & 10 & 6 & $8.94 \mathrm{E}-03$ & $2.83 \mathrm{E}-02$ & $5.37 \mathrm{E}-03$ \\
\hline $241-\mathrm{T}-203$ & $\widehat{\mathrm{GA}}$ & 2 & 0 & NA & $6.99 \mathrm{E}-02$ & $0.00 E+00$ \\
\hline $241-\mathrm{TX}-104$ & GA & 10 & 10 & $1.27 \mathrm{E}+03$ & $1.27 \mathrm{E}+03$ & $1.27 E+03$ \\
\hline $241-\mathrm{U}-101$ & GA & 8 & 8 & $1.75 E+\infty$ & $1.75 \mathrm{E}+00$ & $1.75 \mathrm{E}+00$ \\
\hline $241-U-102$ & $\mathrm{GA}$ & 10 & 10 & $2.20 \mathrm{E}+01$ & $2.20 \mathrm{E}+01$ & $2.20 \mathrm{E}+01$ \\
\hline $241-U-103$ & $\mathrm{GA}$ & 18 & 14 & $2.92 \mathrm{E}+01$ & $2.79 E+01$ & $2.27 \mathrm{E}+01$ \\
\hline $241-U-105$ & GA & 8 & 8 & $4.58 \mathrm{E}+01$ & $4.58 E+01$ & $4.58 E+01$ \\
\hline $241-U-106$ & $\mathrm{GA}$ & 8 & 8 & $2.99 \mathrm{E}+02$ & $2.99 \mathrm{E}+02$ & $2.99 E+02$ \\
\hline $241-U-107$ & $\mathrm{GA}$ & 40 & 12 & $1.12 \mathrm{E}+01$ & $9.57 \mathrm{E}+00$ & $3.36 \mathrm{E}+00$ \\
\hline $241-U-108$ & $\overrightarrow{\mathrm{GA}}$ & 6 & 1 & $8.88 E+00$ & $9.79 \mathrm{E}+00$ & $1.48 \mathrm{E}+00$ \\
\hline 241-U-109 & $\mathrm{GA}$ & 4 & 1 & $1.07 \mathrm{E}+00$ & $7.47 E+00$ & $2.68 \mathrm{E}-01$ \\
\hline
\end{tabular}


HNF-4534 Rev. 1

Table A-6. Mean ${ }^{80 \%} \mathrm{Sr}$ Concentration $(\mu \mathrm{Ci} / \mathrm{g})$, SST Liquid Samples

\begin{tabular}{|c|c|c|c|c|c|c|}
\hline Irank & Analyte & Ninn 010 & $\begin{array}{l}\text { Num. } \\
\text { A bove DL }\end{array}$ & (111 & $(-110$ & $\sqrt{18}$ \\
\hline $241-\mathrm{A}-101$ & ${ }^{89190} \mathrm{Sr}$ & 16 & 16 & $6.82 \mathrm{E}+01$ & $6.82 \mathrm{E}+01$ & $6.82 \mathrm{E}+01$ \\
\hline $241-\mathrm{AX}-101$ & ${ }^{89} 190 \mathrm{Sr}$ & 6 & 6 & $2.65 \mathrm{E}+02$ & $2.65 \mathrm{E}+02$ & $2.65 \mathrm{E}+02$ \\
\hline $241-\mathrm{BY}-103$ & ${ }^{89 / 90} \mathrm{Sr}$ & 4 & 4 & $1.12 \mathrm{E}+02$ & $1.12 \mathrm{E}+02$ & $1.12 \mathrm{E}+02$ \\
\hline 241-BY-105 & ${ }^{8990} \mathrm{Sr}$ & 42 & 42 & $1.15 \mathrm{E}+02$ & $1.15 \mathrm{E}+02$ & $1.15 \mathrm{E}+02$ \\
\hline 241-BY-106 & ${ }^{8990} \mathrm{Sr}$ & 6 & 6 & $3.77 \mathrm{E}+01$ & $3.77 \mathrm{E}+01$ & $3.77 \mathrm{E}+01$ \\
\hline $241-\mathrm{C}-106$ & ${ }^{8990} \mathrm{Sr}$ & 14 & 14 & $6.55 \mathrm{E}+02$ & $6.55 E+02$ & $6.55 E+02$ \\
\hline $241-C-110$ & ${ }^{90} \mathrm{Sr}$ & 2 & 2 & $2.78 \mathrm{E}+01$ & $2.78 \mathrm{E}+01$ & $2.78 \mathrm{E}+01$ \\
\hline $241-S-102$ & ${ }^{80900} \mathrm{Sr}$ & 6 & 6 & $3.11 \mathrm{E}+02$ & $3.11 \mathrm{E}+02$ & $3.11 \mathrm{E}+02$ \\
\hline $241-S-103$ & ${ }^{89 / 90} \mathrm{Sr}$ & 6 & 6 & $4.20 \mathrm{E}+02$ & $4.20 \mathrm{E}+02$ & $4.20 \mathrm{E}+02$ \\
\hline $241-S-106$ & ${ }^{8900} \mathrm{Sr}$ & 16 & 16 & $5.67 \mathrm{E}+01$ & $5.67 \mathrm{E}+01$ & $5.67 \mathrm{E}+01$ \\
\hline $241-S-109$ & ${ }^{89100} \mathrm{Sr}$ & 6 & 6 & $2.70 \mathrm{E}+02$ & $2.70 \mathrm{E}+02$ & $2.70 \mathrm{E}+02$ \\
\hline $241-S-111$ & ${ }^{89} 900 \mathrm{Sr}$ & 16 & 16 & $2.26 \mathrm{E}+02$ & $2.26 \mathrm{E}+02$ & $2.26 \mathrm{E}+02$ \\
\hline $241-S X-101$ & ${ }^{89 / 90} \mathrm{Sr}$ & 20 & 20 & $8.03 E+01$ & $8.03 E+01$ & $8.03 E+01$ \\
\hline $241-S X-102$ & ${ }^{89 / 90} \mathrm{Sr}$ & 2 & 2 & $2.34 \mathrm{E}+01$ & $2.34 \mathrm{E}+01$ & $2.34 \mathrm{E}+01$ \\
\hline 241-SX-103 & ${ }^{69 / 90} \mathrm{Sr}$ & 6 & 6 & $1.15 \mathrm{E}+02$ & $1.15 \mathrm{E}+02$ & $1.15 \mathrm{E}+02$ \\
\hline 241-SX-104 & ${ }^{89190} \mathrm{SI}$ & 2 & 2 & $6.33 \mathrm{E}+01$ & $6.33 \mathrm{E}+01$ & $6.33 \mathrm{E}+01$ \\
\hline $241-S X-105$ & ${ }^{89 / 90} \mathrm{Sr}$ & 28 & 28 & $1.60 \mathrm{E}+02$ & $1.60 \mathrm{E}+02$ & $1.60 \mathrm{E}+02$ \\
\hline $241-S X-106$ & ${ }^{89 / 90} \mathrm{Sr}$ & 16 & 16 & $3.40 \mathrm{E}+02$ & $3.40 \mathrm{E}+02$ & $3.40 \mathrm{E}+02$ \\
\hline $241-T-105$ & ${ }^{90} \mathrm{Sr}$ & 2 & 2 & $3.74 \mathrm{E}+02$ & $3.74 \mathrm{E}+02$ & $3.74 \mathrm{E}+02$ \\
\hline $241-\mathrm{T}-107$ & ${ }^{90} \mathrm{Sr}$ & 6 & 6 & $5.94 \mathrm{E}+01$ & $5.94 \mathrm{E}+01$ & $5.94 \mathrm{E}+01$ \\
\hline $241-\mathrm{T}-110$ & ${ }^{90} \mathrm{Sr}$ & 2 & 2 & $5.30 \mathrm{E}-01$ & $5.30 \mathrm{E}-01$ & $5.30 \mathrm{E}-01$ \\
\hline $241-U-102$ & ${ }^{89 / 90} \mathrm{Sr}$ & 10 & 10 & $8.04 E+03$ & $8.04 \mathrm{E}+03$ & $8.04 \mathrm{E}+03$ \\
\hline $241-U-103$ & ${ }^{89 / 90} \mathrm{Sr}$ & 8 & 8 & $1.05 E+04$ & $1.05 \mathrm{E}+04$ & 1.05E+04 \\
\hline $241-U-105$ & ${ }^{89,90} \mathrm{Sr}$ & 6 & 6 & $2.51 \mathrm{E}+04$ & $2.51 E+04$ & $2.51 \mathrm{E}+04$ \\
\hline 241-U-107 & ${ }^{8990} \mathrm{Sr}$ & 22 & 22 & $3.61 \mathrm{E}+02$ & $3.61 \mathrm{E}+02$ & $3.61 E+02$ \\
\hline $241-U-108$ & ${ }^{8990} \mathrm{Sr}$ & 2 & 2 & $3.45 E+02$ & $3.45 E+02$ & $3.45 \mathrm{E}+02$ \\
\hline $241-U-109$ & ${ }^{891900} \mathrm{Sr}$ & 2 & 2 & $9.31 \mathrm{E}+02$ & $9.31 E+02$ & $9.31 \mathrm{E}+02$ \\
\hline
\end{tabular}

A-11 
HNF-4534 Rev. 1

Table A-7. Mean ${ }^{137} \mathrm{Cs}$ Concentration $(\mu \mathrm{Ci} / \mathrm{g})$, DST Solid Samples

\begin{tabular}{|c|c|c|c|c|c|c|}
\hline thall & anilyte. & Num obs & $\begin{array}{l}\text { Tinn? } \\
\text { A bove D1 }\end{array}$ & $\sqrt{11}$ & ting & $(1,15$ \\
\hline $241-\mathrm{AN}-102$ & ${ }^{137} \mathrm{Cs}$ & 12 & 12 & $2.39 \mathrm{E}+02$ & $2.39 \mathrm{E}+02$ & $2.39 \mathrm{E}+02$ \\
\hline 241-AN-103 & ${ }^{137} \mathrm{Cs}$ & 5 & 5 & $2.51 \mathrm{E}+02$ & $2.51 \mathrm{E}+02$ & $2.51 \mathrm{E}+02$ \\
\hline $241-\mathrm{AN}-104$ & ${ }^{137} \mathrm{Cs}$ & 5 & 5 & $3.46 \mathrm{E}+02$ & $3.46 \mathrm{E}+02$ & $3.46 \mathrm{E}+02$ \\
\hline 241-AN-105 & ${ }^{137} \mathrm{Cs}$ & 7 & 7 & $2.67 \mathrm{E}+02$ & $2.67 \mathrm{E}+02$ & $2.67 \mathrm{E}+02$ \\
\hline $241-\mathrm{AN}-107$ & ${ }^{137} \mathrm{Cs}$ & 5 & 5 & $1.74 \mathrm{E}+02$ & $1.74 \mathrm{E}+02$ & $1.74 \mathrm{E}+02$ \\
\hline $241-\mathrm{AW}-101$ & ${ }^{137} \mathrm{Cs}$ & 11 & 11 & $2.55 \mathrm{E}+02$ & $2.55 \mathrm{E}+02$ & $2.55 \mathrm{E}+02$ \\
\hline $241-\mathrm{AW}-102$ & ${ }^{137} \mathrm{Cs}$ & 4 & 4 & $8.64 \mathrm{E}+01$ & $8.64 \mathrm{E}+01$ & $8.64 \mathrm{E}+01$ \\
\hline $241-A W-105$ & ${ }^{137} \mathrm{Cs}$ & 69 & 69 & $3.82 \mathrm{E}+01$ & $3.82 \mathrm{E}+01$ & $3.82 \mathrm{E}+01$ \\
\hline $241-\mathrm{AW}-106$ & ${ }^{137} \mathrm{Cs}$ & 10 & 10 & $1.15 \mathrm{E}+02$ & $1.15 \mathrm{E}+02$ & $1.15 \mathrm{E}+02$ \\
\hline $241-\mathrm{AY}-101$ & ${ }^{137} \mathrm{Cs}$ & 2 & 2 & $8.56 \mathrm{E}+01$ & $8.56 \mathrm{E}+01$ & $8.56 \mathrm{E}+01$ \\
\hline $241-A Y-102$ & ${ }^{137} \mathrm{Cs}$ & 2 & 2 & $2.83 E+02$ & $2.83 E+02$ & $2.83 \mathrm{E}+02$ \\
\hline $241-\mathrm{AZ}-101$ & ${ }^{137} \mathrm{Cs}$ & & & NA & NA & NA \\
\hline 241-AZ-102 & ${ }^{137} \mathrm{Cs}$ & 2 & 2 & $8.25 \mathrm{E}+02$ & $8.25 \mathrm{E}+02$ & $8.25 E+02$ \\
\hline $241-S Y-101$ & ${ }^{137} \mathrm{Cs}$ & 218 & 218 & $3.46 \mathrm{E}+02$ & $3.46 \mathrm{E}+02$ & $3.46 \mathrm{E}+02$ \\
\hline $241-S Y-102$ & ${ }^{137} \mathrm{Cs}$ & 2 & 2 & $1.04 E+02$ & $1.04 E+02$ & $1.04 \mathrm{E}+02$ \\
\hline $241-S Y-103$ & ${ }^{137} \mathrm{Cs}$ & 16 & 16 & $2.26 \mathrm{E}+02$ & $2.26 \mathrm{E}+02$ & $2.26 \mathrm{E}+02$ \\
\hline
\end{tabular}

A-12 
HNF-4534 Rev. 1

Table A-8. Mean Alpha Concentration $(\mu \mathrm{Ci} / \mathrm{g})$, DST Solid Samples

\begin{tabular}{|c|c|c|c|c|c|c|}
\hline Tank & spulyte. & Mum obs & Above DL & $M i$ & 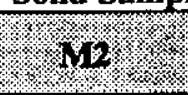 & $\sqrt{1} \mathrm{~m}$ \\
\hline $241-\mathrm{AN}-102$ & GA & 18 & 18 & 5.52E-01 & $5.52 \mathrm{E}-01$ & $5.52 \mathrm{E}-01$ \\
\hline $241-\mathrm{AN}-103$ & GA & 63 & 13 & $1.72 \mathrm{E}-02$ & $1.78 \mathrm{E}-02$ & $3.55 \mathrm{E}-03$ \\
\hline $241-\mathrm{AN}-104$ & GA & 35 & 21 & $4.07 \mathrm{E}-02$ & $6.45 \mathrm{E}-02$ & $2.44 \mathrm{E}-02$ \\
\hline $241-\mathrm{AN}-105$ & $\mathrm{GA}$ & 28 & 18 & $2.78 \mathrm{E}-02$ & $2.43 \mathrm{E}-02$ & $1.79 \mathrm{E}-02$ \\
\hline $241-\mathrm{AN}-107$ & GA & 17 & 17 & $1.00 \mathrm{E}+00$ & $1.00 \mathrm{E}+00$ & $1.00 \mathrm{E}+00$ \\
\hline 241-AP-105 & GA & 12 & 4 & $6.96 \mathrm{E}-03$ & $1.01 \mathrm{E}-02$ & $2.32 \mathrm{E}-03$ \\
\hline 241-AW-101 & $\overline{\mathrm{GA}}$ & 89 & 38 & $7.97 \mathrm{E}-02$ & $3.89 \mathrm{E}-02$ & $3.40 \mathrm{E}-02$ \\
\hline $241-\mathrm{AW}-102$ & GA & 6 & 6 & $2.40 \mathrm{E}+00$ & $2.40 \mathrm{E}+00$ & $2.40 \mathrm{E}+00$ \\
\hline $241-\mathrm{AW}-103$ & GA & 28 & 28 & $3.83 \mathrm{E}-01$ & $3.83 \mathrm{E}-01$ & $3.83 \mathrm{E}-01$ \\
\hline 241-AW-104 & GA & 18 & 18 & $1.28 \mathrm{E}+00$ & $1.28 \mathrm{E}+00$ & $1.28 \mathrm{E}+00$ \\
\hline 241-AW-105 & GA & 41 & 41 & $1.75 \mathrm{E}+00$ & $1.75 \mathrm{E}+00$ & $1.75 \mathrm{E}+00$ \\
\hline $241-\mathrm{AW}-106$ & GA & 4 & 4 & $2.22 \mathrm{E}-01$ & $2.22 \mathrm{E}-01$ & $2.22 \mathrm{E}-01$ \\
\hline $241-\mathrm{AY}-101$ & GA & 6 & 6 & $3.80 \mathrm{E}+00$ & $3.80 \mathrm{E}+00$ & $3.80 \mathrm{E}+00$ \\
\hline $241-A Y-102$ & ${ }^{241} \mathrm{Am}$ & 2 & 2 & $2.24 \mathrm{E}+01$ & $2.24 \mathrm{E}+01$ & $2.24 \mathrm{E}+01$ \\
\hline $241-\mathrm{AZ}-101$ & $\mathrm{GA}$ & 12 & 12 & $8.16 \mathrm{E}+01$ & $8.16 \mathrm{E}+01$ & $8.16 \mathrm{E}+01$ \\
\hline $241-\mathrm{AZ}-102$ & $\mathrm{GA}$ & 2 & 2 & $5.37 \mathrm{E}+01$ & $5.37 \mathrm{E}+01$ & $5.37 \mathrm{E}+01$ \\
\hline $241-S Y-101$ & GA & 134 & 122 & $3.99 \mathrm{E}-01$ & $3.83 \mathrm{E}-01$ & $3.63 \mathrm{E}-01$ \\
\hline $241-S Y-102$ & GA & 10 & 10 & $2.30 \mathrm{E}+01$ & $2.30 \mathrm{E}+01$ & $2.30 \mathrm{E}+01$ \\
\hline $241-S Y-103$ & $\overline{\mathrm{GA}}$ & 44 & 22 & $8.93 \mathrm{E}-01$ & $5.79 \mathrm{E}-01$ & $4.47 \mathrm{E}-01$ \\
\hline
\end{tabular}


HNF-4534 Rev. 1

Table A-9. Mean ${ }^{\mathrm{S} r}$ Concentration $(\mu \mathrm{Ci} / \mathrm{g})$, DST Solid Samples

\begin{tabular}{|c|c|c|c|c|c|c|}
\hline (ank & innute. & Nuin Obs & Num. & mi & 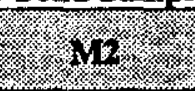 & $(4)$ \\
\hline 241-AN-102 & ${ }^{89190} \mathrm{Sr}$ & 12 & 12 & $1.17 \mathrm{E}+02$ & $1.17 \mathrm{E}+02$ & 1.17E+02 \\
\hline 241-AN-103 & ${ }^{89190} \mathrm{Sr}$ & 2 & 2 & $2.66 \mathrm{E}+00$ & $2.66 \mathrm{E}+00$ & $2.66 \mathrm{E}+00$ \\
\hline 241-AN-104 & ${ }^{39190} \mathrm{Sr}$ & 5 & 5 & $3.36 \mathrm{E}+01$ & $3.36 \mathrm{E}+01$ & $3.36 \mathrm{E}+01$ \\
\hline 241-AN-105 & ${ }^{89 / 90} \mathrm{Sr}$ & 7 & 7 & $1.87 \mathrm{E}+01$ & $1.87 \mathrm{E}+01$ & $1.87 \mathrm{E}+01$ \\
\hline 241-AN-107 & ${ }^{59100} \mathrm{Sr}$ & 5 & 5 & $2.53 \mathrm{E}+02$ & $2.53 E+02$ & $2.53 \mathrm{E}+02$ \\
\hline $241-\mathrm{AW}-101$ & ${ }^{899190} \mathrm{Sr}$ & 11 & 11 & $3.43 \mathrm{E}+01$ & $3.43 E+01$ & $3.43 \mathrm{E}+01$ \\
\hline $241-\mathrm{AW}-102$ & ${ }^{8990} \mathrm{Sr}$ & 4 & 4 & $6.64 \mathrm{E}+02$ & $6.64 \mathrm{E}+02$ & $6.64 \mathrm{E}+02$ \\
\hline 241-AW-105 & ${ }^{89900} \mathrm{Sr} \&{ }^{90} \mathrm{Sr}$ & 60 & 60 & $6.22 \mathrm{E}+01$ & $6.22 \mathrm{E}+01$ & $6.22 \mathrm{E}+01$ \\
\hline 241-AW-106 & ${ }^{89 \times 90} \mathrm{Sr}$ & 10 & 10 & $2.26 \mathrm{E}+01$ & $2.26 \mathrm{E}+01$ & $2.26 \mathrm{E}+01$ \\
\hline $241-\mathrm{AY}-101$ & ${ }^{89190} \mathrm{Sr}$ & 2 & 2 & $4.61 \mathrm{E}+03$ & $4.61 \mathrm{E}+03$ & $4.61 \mathrm{E}+03$ \\
\hline $241-\mathrm{AY}-102$ & ${ }^{8960} \mathrm{Sr}$ & 2 & 2 & $7.67 \mathrm{E}+04$ & $7.67 \mathrm{E}+04$ & $7.67 \mathrm{E}+04$ \\
\hline $241-A Z-101$ & ${ }^{899190} \mathrm{Sr}$ & & & NA & NA & NA \\
\hline $241-\mathrm{AZ}-102$ & ${ }^{8990} \mathrm{Sr}$ & 2 & 2 & $9.30 \mathrm{E}+03$ & $9.30 \mathrm{E}+03$ & $9.30 \mathrm{E}+03$ \\
\hline $241-S Y-101$ & ${ }^{89 / 90} \mathrm{Sr} \&{ }^{90} \mathrm{Sr}$ & 61 & 61 & $2.65 \mathrm{E}+01$ & $2.65 \mathrm{E}+01$ & $2.65 E+01$ \\
\hline $241-\mathrm{SY}-102$ & ${ }^{89980} \mathrm{Sr}$ & 2 & 2 & $2.49 \mathrm{E}+01$ & $2.49 \mathrm{E}+01$ & $2.49 \mathrm{E}+01$ \\
\hline $241-S Y-103$ & ${ }^{89 / 90} \mathrm{Sr}$ & 16 & 16 & $9.64 \mathrm{E}+00$ & $9.64 \mathrm{E}+00$ & $9.64 \mathrm{E}+00$ \\
\hline
\end{tabular}

A-14 
HNF-4534 Rev. 1

Table A-10. Mean ${ }^{137} \mathrm{Cs}$ Concentration $(\mu \mathrm{C} / \mathrm{L})$, DST Liquid Samples

\begin{tabular}{|c|c|c|c|c|c|c|}
\hline tani & Analote & Numphs & Alure DL: & il & $10 \mathrm{p}$ & $\sqrt{15}$ \\
\hline 241-AN-101 & ${ }^{137} \mathrm{Cs}$ & 12 & 12 & $1.01 \mathrm{E}+05$ & $1.01 \mathrm{E}+05$ & $1.01 \mathrm{E}+05$ \\
\hline $241-\mathrm{AN}-102$ & ${ }^{137} \mathrm{Cs}$ & 19 & 19 & $3.66 \mathrm{E}+05$ & $3.66 \mathrm{E}+05$ & $3.66 \mathrm{E}+05$ \\
\hline $241-\mathrm{AN}-103$ & ${ }^{137} \mathrm{Cs}$ & 8 & 8 & $7.86 \mathrm{E}+05$ & $7.86 \mathrm{E}+05$ & $7.86 \mathrm{E}+05$ \\
\hline 241-AN-104 & ${ }^{137} \mathrm{Cs}$ & 8 & 8 & $6.54 \mathrm{E}+05$ & $6.54 \mathrm{E}+05$ & $6.54 \mathrm{E}+05$ \\
\hline 241-AN-105 & ${ }^{137} \mathrm{Cs}$ & 8 & 8 & $4.02 E+05$ & $4.02 E+05$ & $4.02 \mathrm{E}+05$ \\
\hline $241-\mathrm{AN}-107$ & ${ }^{137} \mathrm{Cs}$ & 8 & 8 & $3.63 \mathrm{E}+05$ & $3.63 \mathrm{E}+05$ & $3.63 \mathrm{E}+05$ \\
\hline $241-\mathrm{AP}-101$ & ${ }^{137} \mathrm{Cs}$ & 14 & 14 & $1.61 E+05$ & $1.61 \mathrm{E}+05$ & $1.61 \mathrm{E}+05$ \\
\hline 241-AP-102 & ${ }^{137} \mathrm{Cs}$ & 52 & 52 & $2.25 \mathrm{E}+05$ & $2.25 \mathrm{E}+05$ & $2.25 \mathrm{E}+05$ \\
\hline 241-AP-103 & ${ }^{137} \mathrm{Cs}$ & 26 & 26 & $6.24 \mathrm{E}+04$ & $6.24 \mathrm{E}+04$ & $6.24 \mathrm{E}+04$ \\
\hline $241-\mathrm{AP}-104$ & ${ }^{137} \mathrm{Cs}$ & 4 & 4 & $4.97 \mathrm{E}+03$ & $4.97 \mathrm{E}+03$ & $4.97 \mathrm{E}+03$ \\
\hline 241-AP-105 & ${ }^{137} \mathrm{Cs}$ & 32 & 32 & $2.10 \mathrm{E}+05$ & $2.10 \mathrm{E}+05$ & $2.10 \mathrm{E}+05$ \\
\hline 241-AP-106 & ${ }^{137} \mathrm{Cs}$ & 36 & 36 & $3.98 E+04$ & $3.98 \mathrm{E}+04$ & $3.98 \mathrm{E}+04$ \\
\hline 241-AP-107 & ${ }^{137} \mathrm{Cs}$ & 24 & 21 & $3.03 \mathrm{E}+04$ & $2.65 \mathrm{E}+04$ & $2.65 \mathrm{E}+04$ \\
\hline 241-AP-108 & ${ }^{137} \mathrm{Cs}$ & 22 & 22 & $7.07 \mathrm{E}+04$ & $7.07 \mathrm{E}+04$ & $7.07 \mathrm{E}+04$ \\
\hline $241-\mathrm{AW}-101$ & ${ }^{137} \mathrm{Cs}$ & 7 & 7 & $4.62 \mathrm{E}+05$ & $4.62 \mathrm{E}+05$ & $4.62 \mathrm{E}+05$ \\
\hline $241-\mathrm{AW}-102$ & ${ }^{137} \mathrm{Cs}$ & 18 & 18 & $3.48 \mathrm{E}+04$ & $3.48 \mathrm{E}+04$ & $3.48 \mathrm{E}+04$ \\
\hline $241-\mathrm{AW}-103$ & ${ }^{137} \mathrm{Cs}$ & 2 & 2 & $2.06 \mathrm{E}+04$ & $2.06 \mathrm{E}+04$ & $2.06 \mathrm{E}+04$ \\
\hline $241-\mathrm{AW}-104$ & ${ }^{137} \mathrm{Cs}$ & 12 & 12 & $1.32 \mathrm{E}+04$ & $1.32 \mathrm{E}+04$ & $1.32 E+04$ \\
\hline $241-\mathrm{AW}-105$ & ${ }^{137} \mathrm{Cs}$ & 37 & 37 & $1.41 \mathrm{E}+04$ & $1.41 \mathrm{E}+04$ & $1.41 E+04$ \\
\hline $241-\mathrm{AW}-106$ & ${ }^{137} \mathrm{Cs}$ & 11 & 11 & $1.86 \mathrm{E}+05$ & $1.86 \mathrm{E}+05$ & $1.86 \mathrm{E}+05$ \\
\hline $241-\mathrm{AY}-101$ & ${ }^{137} \mathrm{Cs}$ & 20 & 20 & $8.81 \mathrm{E}+04$ & $8.81 \mathrm{E}+04$ & $8.81 \mathrm{E}+04$ \\
\hline $241-\mathrm{AY}-102$ & ${ }^{137} \mathrm{Cs}$ & 32 & 32 & $3.59 \mathrm{E}+03$ & $3.59 \mathrm{E}+03$ & $3.59 \mathrm{E}+03$ \\
\hline 241-AZ-101 & ${ }^{137} \mathrm{Cs}$ & 6 & 6 & $1.59 \mathrm{E}+06$ & $1.59 \mathrm{E}+06$ & $1.59 \mathrm{E}+06$ \\
\hline $241-A Z-102$ & ${ }^{137} \mathrm{Cs}$ & 8 & 8 & $1.07 \mathrm{E}+06$ & $1.07 \mathrm{E}+06$ & $1.07 \mathrm{E}+06$ \\
\hline $241-S Y-101$ & ${ }^{137} \mathrm{Cs}$ & 62 & 62 & $9.96 \mathrm{E}+05$ & $9.96 \mathrm{E}+05$ & $9.96 \mathrm{E}+05$ \\
\hline $241-S Y-102$ & ${ }^{137} \mathrm{Cs}$ & 34 & 34 & $5.49 \mathrm{E}+04$ & $5.49 \mathrm{E}+04$ & $5.49 \mathrm{E}+04$ \\
\hline 241-SY-103 & ${ }^{137} \mathrm{Cs}$ & 4 & 4 & $3.99 \mathrm{E}+05$ & $3.99 \mathrm{E}+05$ & $3.99 \mathrm{E}+05$ \\
\hline
\end{tabular}

A-15 
HNF-4534 Rev. 1

Table A-11. Mean Alpha Concentration $(\mu \mathrm{Ci} / \mathrm{L})$, DST Liquid Samples

\begin{tabular}{|c|c|c|c|c|c|c|}
\hline Tonk & Jualite & friningis & $\begin{array}{l}\text { Noun. } \\
\text { Above DL }\end{array}$ & in & $y=$ & $y_{1}$ \\
\hline 241-AN-101 & GA & 12 & 0 & NA & $1.03 \mathrm{E}+00$ & $0.00 \mathrm{E}+00$ \\
\hline $241-\mathrm{AN}-102$ & GA & 31 & 31 & $1.76 \mathrm{E}+02$ & $1.76 \mathrm{E}+02$ & $1.76 \mathrm{E}+02$ \\
\hline 241-AN-103 & GA & 36 & 6 & $5.77 \mathrm{E}+01$ & $3.73 \mathrm{E}+01$ & $9.61 \mathrm{E}+00$ \\
\hline $241-\mathrm{AN}-104$ & GA & 56 & 8 & $1.23 \mathrm{E}+01$ & $2.68 \mathrm{E}+01$ & $1.75 \mathrm{E}+00$ \\
\hline $241-\mathrm{AN}-105$ & GA & 58 & 5 & $2.84 \mathrm{E}+01$ & $2.93 \mathrm{E}+01$ & $2.45 \mathrm{E}+00$ \\
\hline $241-\mathrm{AN}-106$ & $\mathrm{GA}$ & 18 & 4 & $1.01 \mathrm{E}+00$ & $6.08 \mathrm{E}+00$ & $2.25 \mathrm{E}-01$ \\
\hline $241-\mathrm{AN}-107$ & GA & 31 & 31 & $8.17 \mathrm{E}+02$ & $8.17 \mathrm{E}+02$ & $8.17 \mathrm{E}+02$ \\
\hline $241-\mathrm{AP}-101$ & $\mathrm{GA}$ & 14 & 2 & $5.95 \mathrm{E}-03$ & $2.26 \mathrm{E}+00$ & $8.49 \mathrm{E}-04$ \\
\hline $241-\mathrm{AP}-102$ & ${ }^{241} \mathrm{Am}$ & 46 & 46 & $4.78 \mathrm{E}-01$ & $4.78 \mathrm{E}-01$ & $4.78 \mathrm{E}-01$ \\
\hline $241-A P-103$ & $\mathrm{GA}$ & 6 & 6 & $1.68 \mathrm{E}+01$ & $1.68 \mathrm{E}+01$ & $1.68 \mathrm{E}+01$ \\
\hline $241-\mathrm{AP}-104$ & $\mathrm{GA}$ & 8 & 8 & $3.28 \mathrm{E}-01$ & $3.28 \mathrm{E}-01$ & $3.28 \mathrm{E}-01$ \\
\hline $241-A P-105$ & $\mathrm{GA}$ & 16 & 2 & $1.01 E+01$ & $6.98 \mathrm{E}+00$ & $1.26 \mathrm{E}+00$ \\
\hline $241-\mathrm{AP}-106$ & $\mathrm{GA}$ & 3 & 0 & $\mathrm{NA}$ & $2.11 \mathrm{E}+00$ & $0.00 \mathrm{E}+00$ \\
\hline $241-\mathrm{AP}-107$ & GA & 15 & 2 & $7.77 \mathrm{E}-01$ & $2.13 \mathrm{E}+00$ & $1.04 \mathrm{E}-01$ \\
\hline 241-AP-108 & GA & 12 & 0 & NA & $3.46 \mathrm{E}+00$ & $0.00 \mathrm{E}+00$ \\
\hline $241-\mathrm{AW}-101$ & GA & 57 & 8 & $8.27 \mathrm{E}+00$ & $1.35 \mathrm{E}+01$ & $1.16 \mathrm{E}+00$ \\
\hline $241-\mathrm{AW}-102$ & $\mathrm{GA}$ & 15 & 4 & $1.21 \mathrm{E}+00$ & $1.47 \mathrm{E}+00$ & $3.24 \mathrm{E}-01$ \\
\hline $241-\mathrm{AW}-103$ & GA & 4 & 0 & $\mathrm{NA}$ & $4.82 \mathrm{E}-01$ & $0.00 \mathrm{E}+00$ \\
\hline $241-\mathrm{AW}-104$ & GA & 38 & 18 & $3.02 \mathrm{E}+00$ & $3.74 \mathrm{E}+00$ & $1.43 \mathrm{E}+\infty 0$ \\
\hline $241-A W-105$ & $\mathrm{GA}$ & 29 & 15 & $1.83 \mathrm{E}+00$ & $1.02 \mathrm{E}+00$ & $9.48 \mathrm{E}-01$ \\
\hline $241-\mathrm{AW}-106$ & $\mathrm{GA}$ & 5 & 1 & $2.87 \mathrm{E}+01$ & $1.36 \mathrm{E}+01$ & $5.74 \mathrm{E}+00$ \\
\hline $241-\mathrm{AY}-101$ & $\mathrm{GA}$ & 28 & 25 & $6.62 \mathrm{E}+01$ & $5.98 \mathrm{E}+01$ & $5.91 \mathrm{E}+01$ \\
\hline $241-\mathrm{AY}-102$ & ${ }^{241} \mathrm{Am}$ & 32 & 7 & $5.17 \mathrm{E}-01$ & $1.94 \mathrm{E}-01$ & $1.13 \mathrm{E}-01$ \\
\hline $241-A Z-101$ & $\mathrm{GA}$ & $\mathrm{DL}$ & $D L$ & $6.20 \mathrm{E}+01$ & $6.20 \mathrm{E}+01$ & $6.20 \mathrm{E}+01$ \\
\hline $241-\mathrm{AZ}-102$ & $\mathrm{GA}$ & 3 & 1 & $8.56 E+01$ & $6.99 \mathrm{E}+01$ & $2.85 E+01$ \\
\hline $241-S Y-101$ & GA & 10 & 10 & $3.72 \mathrm{E}+01$ & $3.72 \mathrm{E}+01$ & $3.72 \mathrm{E}+01$ \\
\hline $241-S Y-102$ & GA & 16 & 13 & $1.15 \mathrm{E}+01$ & $1.60 \mathrm{E}+01$ & $9.34 \mathrm{E}+00$ \\
\hline $241-S Y-103$ & GA & 4 & 0 & NA & $4.59 \mathrm{E}+01$ & $0.00 \mathrm{E}+00$ \\
\hline
\end{tabular}


HNF-4534 Rev. 1

Table A-12. Mean ${ }^{m 00} \mathrm{Sr}$ Concentration $(\mu \mathrm{Ci} / \mathrm{L}), \mathrm{DST}$ Liquid Samples

\begin{tabular}{|c|c|c|c|c|c|c|}
\hline Tani & inglyte & Nivigobs & $\begin{array}{l}\text { Num, } \\
\text { Above DL }\end{array}$ & . & 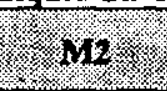 & 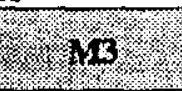 \\
\hline 241-AN-101 & ${ }^{8990} \mathrm{Sr}$ & 12 & 12 & $2.09 \mathrm{E}+02$ & $2.09 E+02$ & $2.09 \mathrm{E}+02$ \\
\hline $241-\mathrm{AN}-102$ & ${ }^{891900} \mathrm{Sr}$ & 19 & 19 & $8.47 \mathrm{E}+04$ & $8.47 \mathrm{E}+04$ & $8.47 \mathrm{E}+04$ \\
\hline $241-\mathrm{AN}-103$ & ${ }^{89900} \mathrm{Sr}$ & 2 & 2 & $2.08 \mathrm{E}+01$ & $2.08 \mathrm{E}+01$ & $2.08 \mathrm{E}+01$ \\
\hline $241-\mathrm{AN}-104$ & ${ }^{891900 \mathrm{Sr}}$ & 8 & 8 & $1.31 \mathrm{E}+02$ & $1.31 \mathrm{E}+02$ & $1.31 \mathrm{E}+02$ \\
\hline $241-\mathrm{AN}-105$ & ${ }^{19900} \mathrm{Sr}$ & 2 & 2 & $4.14 \mathrm{E}+01$ & $4.14 \mathrm{E}+01$ & $4.14 \mathrm{E}+01$ \\
\hline $241-\mathrm{AN}-107$ & ${ }^{8990} \mathrm{Sr}$ & 8 & 8 & $1.01 \mathrm{E}+05$ & $1.01 \mathrm{E}+05$ & $1.01 \mathrm{E}+05$ \\
\hline $241-\mathrm{AP}-101$ & ${ }^{89190} \mathrm{Sr} \&{ }^{90} \mathrm{Sr}$ & 14 & 14 & $1.33 \mathrm{E}+02$ & $1.33 \mathrm{E}+02$ & $1.33 \mathrm{E}+02$ \\
\hline $241-\mathrm{AP}-102$ & ${ }^{90} \mathrm{Sr}$ & 50 & 50 & $1.45 \mathrm{E}+03$ & $1.45 \mathrm{E}+03$ & $1.45 \mathrm{E}+03$ \\
\hline $241-\mathrm{AP}-103$ & ${ }^{89190} \mathrm{Sr} \&{ }^{90} \mathrm{Sr}$ & 14 & 14 & $2.38 \mathrm{E}+02$ & $2.38 \mathrm{E}+02$ & $2.38 \mathrm{E}+02$ \\
\hline $241-\mathrm{AP}-104$ & ${ }^{8990} \mathrm{Sr}$ & 4 & 4 & $8.28 \mathrm{E}+01$ & $8.28 \mathrm{E}+01$ & $8.28 \mathrm{E}+01$ \\
\hline $241-\mathrm{AP}-105$ & ${ }^{89100} \mathrm{Sr} \&^{90} \mathrm{Sr}$ & 33 & 33 & $2.13 \mathrm{E}+02$ & $2.13 \mathrm{E}+02$ & $2.13 E+02$ \\
\hline $241-\mathrm{AP}-106$ & ${ }^{89190} \mathrm{Sr} \&^{90} \mathrm{Sr}$ & 44 & 44 & $1.54 \mathrm{E}+02$ & $1.54 \mathrm{E}+02$ & $1.54 E+02$ \\
\hline $241-\mathrm{AP}-107$ & ${ }^{8990} \mathrm{Sr} \&{ }^{90} \mathrm{Sr}$ & 19 & 18 & $4.05 \mathrm{E}+01$ & $4.05 \mathrm{E}+01$ & $4.05 \mathrm{E}+01$ \\
\hline $241-\mathrm{AP}-108$ & ${ }^{89190} \mathrm{SI}$ & 22 & 22 & $1.74 \mathrm{E}+02$ & $1.74 \mathrm{E}+02$ & $1.74 \mathrm{E}+02$ \\
\hline $241-\mathrm{AW}-101$ & ${ }^{89,900} \mathrm{Sr}$ & 7 & 7 & $3.12 \mathrm{E}+02$ & $3.12 \mathrm{E}+02$ & $3.12 \mathrm{E}+02$ \\
\hline $241-\mathrm{AW}-102$ & ${ }^{89 / 90} \mathrm{Sr} \&^{90} \mathrm{Sr}$ & 22 & 21 & $1.58 \mathrm{E}+02$ & $1.58 \mathrm{E}+02$ & $1.58 \mathrm{E}+02$ \\
\hline $241-\mathrm{AW}-103$ & ${ }^{90} \mathrm{Sr}$ & 2 & 2 & $2.20 \mathrm{E}-01$ & $2.20 \mathrm{E}-01$ & $2.20 \mathrm{E}-01$ \\
\hline $241-\mathrm{AW}-104$ & ${ }^{8990} \mathrm{Sr} \&{ }^{90} \mathrm{Sr}$ & 12 & 12 & $1.60 \mathrm{E}+01$ & $1.60 \mathrm{E}+01$ & $1.60 \mathrm{E}+01$ \\
\hline $241-\mathrm{AW}-105$ & ${ }^{89 / 90} \mathrm{Sr} \&^{90} \mathrm{Sr}$ & 36 & 36 & $6.51 \mathrm{E}+01$ & $6.51 E+01$ & $6.51 E+01$ \\
\hline $241-\mathrm{AW}-106$ & ${ }^{89 / 50} \mathrm{Sr} \&^{90} \mathrm{Sr}$ & 13 & 13 & $3.82 \mathrm{E}+02$ & $3.82 \mathrm{E}+02$ & $3.82 \mathrm{E}+02$ \\
\hline $241-\mathrm{AY}-101$ & ${ }^{89 / 90} \mathrm{Sr}$ & 16 & 16 & $1.89 E+03$ & $1.89 \mathrm{E}+03$ & $1.89 \mathrm{E}+03$ \\
\hline $241-\mathrm{AY}-102$ & ${ }^{89 / 90} \mathrm{Sr} \&{ }^{90} \mathrm{Sr}$ & 32 & 32 & $1.19 \mathrm{E}+03$ & $1.19 \mathrm{E}+03$ & $1.19 \mathrm{E}+03$ \\
\hline $241-A Z-101$ & ${ }^{89900} \mathrm{Sr}$ & 5 & 6 & $1.20 \mathrm{E}+03$ & $1.20 \mathrm{E}+03$ & $1.20 \mathrm{E}+03$ \\
\hline $241-A Z-102$ & ${ }^{89900} \mathrm{Sr}$ & 6 & 6 & $1.79 \mathrm{E}+03$ & $1.79 \mathrm{E}+03$ & $1.79 \mathrm{E}+03$ \\
\hline $241-S Y-101$ & ${ }^{90} \mathrm{Sr}$ & 10 & 10 & $1.53 E+03$ & $1.53 \mathrm{E}+03$ & $1.53 \mathrm{E}+03$ \\
\hline $241-S Y-102$ & ${ }^{89,90} \mathrm{Sr}$ & 34 & 34 & $2.06 \mathrm{E}+02$ & $2.06 \mathrm{E}+02$ & $2.06 \mathrm{E}+02$ \\
\hline $241-S Y-103$ & ${ }^{8990} \mathrm{Sr}$ & 4 & 4 & $2.69 E+03$ & $2.69 \mathrm{E}+03$ & $2.69 \mathrm{E}+03$ \\
\hline
\end{tabular}


HNF-4534 Rev. 1

Table A-13. Data from Tanks 241-AZ-101 and 241-AZ-102

\begin{tabular}{|c|c|c|c|c|c|c|}
\hline hominto & Sinnobs & Aloose bu & 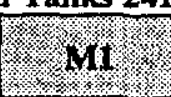 & f & . & 6010 \\
\hline (2.7. & \multicolumn{6}{|c|}{ 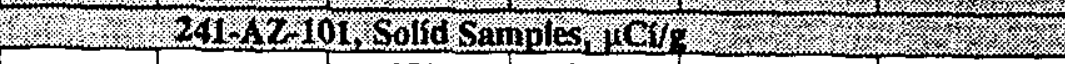 } \\
\hline${ }^{137} \mathrm{Cs}$ & & & NA & NA & NA & NA \\
\hline GA & 12 & 12 & $8.16 \mathrm{E}+01$ & $8.16 \mathrm{E}+01$ & $8.16 \mathrm{E}+01$ & Preliminary \\
\hline${ }^{89990} \mathrm{Sr}$ & & & $\mathrm{NA}$ & NA & NA & NA \\
\hline \multicolumn{7}{|c|}{ 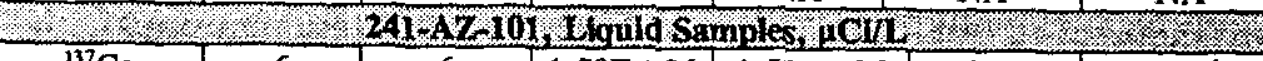 } \\
\hline${ }^{137} \mathrm{Cs}$ & 6 & 6 & $1.59 \mathrm{E}+06$ & $1.59 \mathrm{E}+06$ & $1.59 \mathrm{E}+06$ & $\mathrm{TCD}^{1}$ \\
\hline GA & $D L$ & DL & $6.20 \mathrm{E}+01$ & $6.20 \mathrm{E}+01$ & $6.20 E+01$ & $\mathrm{DL}^{2}$ \\
\hline${ }^{89 / 90} \mathrm{Sr}$ & 6 & 6 & $1.20 \mathrm{E}+03$ & $1.20 \mathrm{E}+03$ & $1.20 \mathrm{E}+03$ & $\mathrm{TCD}$ \\
\hline \multicolumn{7}{|c|}{ 241 12 102, solid samples, $\mu \mathrm{CH}$} \\
\hline${ }^{137} \mathrm{Cs}$ & 2 & 2 & $8.25 \mathrm{E}+02$ & $8.25 E+02$ & $8.25 E+02$ & Preliminary \\
\hline GA & 2 & 2 & $5.37 \mathrm{E}+01$ & $5.37 \mathrm{E}+01$ & $5.37 \mathrm{E}+01$ & Preliminary \\
\hline${ }^{89 / 90} \mathrm{Sr}$ & 2 & 2 & $9.30 E+03$ & $9.30 E+03$ & $9.30 \mathrm{E}+03$ & Preliminary \\
\hline \multicolumn{7}{|c|}{241 A2,102, Lquid Samples, $1 \mathrm{CLI}$} \\
\hline${ }^{137} \mathrm{Cs}$ & 8 & 8 & $1.07 \mathrm{E}+06$ & $1.07 \mathrm{E}+06$ & $1.07 \mathrm{E}+06$ & Combined $^{3}$ \\
\hline GA & 3 & 1 & $8.56 \mathrm{E}+01$ & $6.99 \mathrm{E}+01$ & $2.85 \mathrm{E}+01$ & $T C D$ \\
\hline${ }^{89 \times 10} \mathrm{Sr}$ & 6 & 6 & $1.79 E+03$ & $1.79 \mathrm{E}+03$ & $1.79 \mathrm{E}+03$ & $\mathrm{TCD}$ \\
\hline
\end{tabular}

'TCD: tank characterization database

${ }^{2} \mathrm{DL}$ : detection limit

${ }^{3}$ Combined: combined TCD \& preliminary data 
RPP-5924 REV 0

HNF-4534 Rev. 1

\section{APPENDIX B}

\section{B.0 UNIT LITER DOSE TABLES}

Tables B-1, B-2, B-3, and B-4 list the ULD (Sv/L) for SST solid samples, SST liquid samples, DST solid samples, and DST liquid samples. The columns labeled ULD.M1, ULD.M2, and ULD.M3 are the ULD estimates when the below detection limit observations are omitted, replaced by the detection limit, and replaced by zero, respectively. NA means not available.

Table B-1. ULD SST Solid Samples (Sv/L) (2 sheets)

\begin{tabular}{|c|c|c|c|c|c|c|}
\hline \multirow{2}{*}{ I. Tonk. } & \multicolumn{3}{|c|}{ TCRP 68} & \multicolumn{3}{|c|}{ TCRP 1} \\
\hline & Guom & U1MD MP & GLa & UTD D & WLD Wu & UKD.MB \\
\hline $241-\mathrm{A}-101$ & $2.15 \mathrm{E}+02$ & $1.92 \mathrm{E}+02$ & $1.90 \mathrm{E}+02$ & $2.54 \mathrm{E}+02$ & $2.18 \mathrm{E}+02$ & $2.15 \mathrm{E}+02$ \\
\hline $241-\mathrm{AX}$ & $2.02 \mathrm{E}+02$ & $1.83 \mathrm{E}+02$ & $1.78 \mathrm{E}+02$ & & $2.04 \mathrm{E}+02$ & $1.96 \mathrm{E}+02$ \\
\hline $241-1$ & $5.91 \mathrm{E}+04$ & $5.91 E+04$ & $5.91 \mathrm{E}+04$ & $7.87 E+04$ & & $7.87 \mathrm{E}+04$ \\
\hline $241-1$ & $2.27 \mathrm{E}+02$ & $2.23 \mathrm{E}+02$ & $1.76 \mathrm{E}+02$ & & & $2.17 \mathrm{E}+02$ \\
\hline 241 & $2.57 \mathrm{E}+01$ & $2.63 \mathrm{E}+01$ & $2.47 \mathrm{E}+01$ & 3.21 & & +01 \\
\hline 241 & $1.99 \mathrm{E}+02$ & $1.99 \mathrm{E}+02$ & $1.99 \mathrm{E}+02$ & 2.8 & & +02 \\
\hline 241 & $7.67 \mathrm{E}+02$ & $7.67 \mathrm{E}+02$ & $7.67 \mathrm{E}+02$ & & & +02 \\
\hline $241-$ & $1.56 \mathrm{E}+03$ & $1.56 \mathrm{E}+03$ & 1.56 & 2.4 & +03 & +03 \\
\hline $241-$ & $6.99 \mathrm{E}+02$ & $6.99 \mathrm{E}+02$ & 6.99 & & +03 & +03 \\
\hline $241-$ & $2.38 \mathrm{E}+02$ & 2.38 & 2.38 & 3.56 & +02 & +02 \\
\hline $241-1$ & $3.95 \mathrm{E}$ & 4.10 & 3.25 & $4.96 \mathrm{E}$ & +02 & +02 \\
\hline $241-B$ & $3.57 \mathrm{E}+02$ & 3.57 & 3.5 & $5.34 \mathrm{E}$ & $5.34 \mathrm{E}+02$ & +02 \\
\hline $241-B$ & $5.79 \mathrm{E}+02$ & 5.71 & 5.40 & $7.38 \mathrm{E}$ & $7.24 \mathrm{E}+02$ & +02 \\
\hline $241-\mathrm{E}$ & $4.40 \mathrm{E}$ & 5.50 & $3.31 \mathrm{E}+02$ & 5.75 & $7.45 \mathrm{E}+02$ & 4.0 \\
\hline 241-B & $1.34 \mathrm{E}$ & 1.28 & 1.271 & $1.56 \mathrm{E}+02$ & $1.46 \mathrm{E}+02$ & 1.4 \\
\hline 241-B & $1.71 \mathrm{E}$ & 1.56 & $1.50 \mathrm{E}+02$ & 2.08 & 1.84 & 1.7 \\
\hline $241-B$ & $3.32 \mathrm{E}$ & 3.27 & $3.24 \mathrm{E}+02$ & $4.08 \mathrm{E}+02$ & 4.01 & 3.9 \\
\hline $241-\mathrm{C}$ & +04 & 2.88 & $2.88 \mathrm{E}+04$ & $4.13 E+04$ & $4.13 E+04$ & 4.1 \\
\hline $241-\mathrm{C}$ & $1.15 \mathrm{E}$ & 1.15 & $1.15 \mathrm{E}+04$ & $1.77 \mathrm{E}+04$ & +04 & 1.7 \\
\hline $241-0$ & $5.93 \mathrm{E}$ & 5.93 & $5.93 \mathrm{E}+03$ & $8.68 \mathrm{E}+03$ & $8.68 \mathrm{E}+03$ & 8.6 \\
\hline $241-C$ & $5.65 \mathrm{E}$ & 6.88 & $4.44 \mathrm{E}+02$ & $6.86 \mathrm{E}+02$ & $E+02$ & 4.9 \\
\hline $241-C$ & $2.28 \mathrm{~F}$ & $2.28 \mathrm{E}+03$ & $2.28 \mathrm{E}+03$ & $2.71 E+03$ & $2.71 E+03$ & 2.7 \\
\hline $241-c$ & $2.31 \mathrm{E}$ & $2.31 \mathrm{E}+02$ & $2.31 \mathrm{E}+02$ & $3.49 \mathrm{E}+02$ & $3.49 \mathrm{E}+02$ & 3.49 \\
\hline $41-1$ & $9.32 \mathrm{E}$ & $9.32 \mathrm{E}+03$ & $9.32 \mathrm{E}+03$ & $1.15 \mathrm{E}+04$ & $1.15 \mathrm{E}+04$ & 1.15 \\
\hline $1-$ & 03 & $3.07 \mathrm{E}+03$ & $3.07 \mathrm{E}+03$ & $3.81 \mathrm{E}+03$ & $3.81 \mathrm{E}+03$ & 3.8 \\
\hline $1-$ & 03 & $1.12 \mathrm{E}+03$ & $1.12 \mathrm{E}+03$ & $1.52 \mathrm{E}+03$ & $1.52 \mathrm{E}+03$ & 1.52 \\
\hline $41-$ & $3.99 \mathrm{E}$ & $3.97 \mathrm{E}+02$ & $3.95 E+02$ & $5.62 \mathrm{E}+02$ & $5.60 \mathrm{E}+02$ & $5.57 \mathrm{E}+02$ \\
\hline $241-S-104$ & $1.55 \mathrm{E}+03$ & & $1.43 \mathrm{E}+03$ & $2.17 \mathrm{E}+03$ & $2.15 \mathrm{E}+03$ & $1.99 \mathrm{E}+03$ \\
\hline
\end{tabular}

B-1 
HNF-4534 Rev. 1

Table B-1. ULD SST Solid Samples (Sv/L) (2 sheets)

\begin{tabular}{|c|c|c|c|c|c|c|}
\hline \multirow{2}{*}{. Thant: } & \multicolumn{2}{|r|}{ TCRP 68} & \multirow{2}{*}{ GTO WM } & (2): & TCRP T1 & \multirow{2}{*}{ GIV } \\
\hline & MODKII & $\triangle 1{ }_{B} M_{2}$ & & 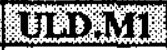 & GU D & \\
\hline $241-S-106$ & $1.21 E+02$ & $1.17 \mathrm{E}+02$ & $1.16 \mathrm{E}+02$ & $1.43 E+02$ & $1.37 \mathrm{E}+02$ & $1.35 \mathrm{E}+02$ \\
\hline $241-S$ & $1.91 \mathrm{E}+03$ & $1.91 \mathrm{E}+03$ & $1.91 \mathrm{E}+03$ & $2.84 \mathrm{E}+03$ & $2.84 \mathrm{E}+03$ & $2.84 E+03$ \\
\hline $241-5$ & $62 \mathrm{E}+01$ & $2.56 \mathrm{E}+01$ & $2.49 \mathrm{E}+01$ & $3.45 \mathrm{E}+01$ & $3.35 \mathrm{E}+01$ & $3.24 \mathrm{E}+01$ \\
\hline $241-5$ & $7.98 \mathrm{E}+02$ & $7.67 \mathrm{E}+02$ & $7.51 \mathrm{E}+02$ & $1.13 \mathrm{E}+03$ & $1.08 \mathrm{E}+03$ & $1.05 \mathrm{E}+03$ \\
\hline $241-$ & $3.33 \mathrm{E}+02$ & $E+02$ & $3.23 E+02$ & $3.93 \mathrm{E}+02$ & $3.78 \mathrm{E}+02$ & $3.77 \mathrm{E}+02$ \\
\hline $241-\mathrm{S}$ & $1.10 \mathrm{E}+03$ & $1.02 \mathrm{E}+03$ & $9.71 E+02$ & $1.59 \mathrm{E}+03$ & 1.46 & $1.39 \mathrm{E}+03$ \\
\hline $241-S X$ & $6.17 \mathrm{E}+02$ & $5.81 \mathrm{E}+02$ & $5.79 \mathrm{E}+02$ & $8.37 \mathrm{E}+02$ & $7.81 E+02$ & $7.78 \mathrm{E}+02$ \\
\hline $241-5$ & $5.85 \mathrm{E}+02$ & +02 & $5.80 \mathrm{E}+02$ & $7.77 \mathrm{E}+02$ & $7.69 \mathrm{E}+02$ & 7.69E +02 \\
\hline $241-S$ & NA & +02 & $4.23 \mathrm{E}+01$ & NA & 2.681 & $2.92 \mathrm{E}+01$ \\
\hline $241-S$ & $1.14 \mathrm{E}+04$ & $1.14 \mathrm{E}+04$ & $1.14 \mathrm{E}+04$ & $1.56 \mathrm{E}+04$ & +04 & $1.56 \mathrm{E}+04$ \\
\hline $241-T-$ & $8.47 E+02$ & $8.47 \mathrm{E}+02$ & $8.47 \mathrm{E}+02$ & $1.14 \mathrm{E}+03$ & +03 & $1.14 E+03$ \\
\hline $241-$ & $2.46 \mathrm{E}+02$ & 2.46 & $2.46 \mathrm{E}+02$ & $3.82 \mathrm{E}+02$ & +02 & $3.82 \mathrm{E}+02$ \\
\hline $241-$ & $1.15 \mathrm{E}+03$ & $1.15 \mathrm{E}+03$ & $1.15 E+03$ & $1.59 \mathrm{E}+03$ & +03 & $1.59 E+03$ \\
\hline $241-$ & $5.36 \mathrm{E}+02$ & +02 & $5.36 \mathrm{E}+02$ & $7.44 \mathrm{E}+02$ & 7.44 & $7.44 \mathrm{E}+02$ \\
\hline 241. & $6.45 \mathrm{E}+02$ & $6.45 \mathrm{E}+02$ & $6.45 \mathrm{E}+02$ & $1.00 \mathrm{E}+03$ & 1.0 & $1.00 \mathrm{E}+03$ \\
\hline 241- & $1.30 \mathrm{E}+03$ & $1.30 \mathrm{E}+03$ & $1.30 \mathrm{E}+03$ & $2.02 \mathrm{E}+03$ & $2.02 \mathrm{E}+03$ & $2.02 E+03$ \\
\hline $241-T-202$ & NA & $3.80 \mathrm{E}+02$ & $3.80 \mathrm{E}+02$ & NA & $5.91 \mathrm{E}+02$ & $5.91 \mathrm{E}+02$ \\
\hline $241-$ & NA & +02 & $3.35 \mathrm{E}+02$ & NA & $5.22 \mathrm{E}+02$ & $5.22 \mathrm{E}+02$ \\
\hline $241-$ & $60 \mathrm{E}+02$ & $2.46 \mathrm{H}$ & $2.46 \mathrm{E}+02$ & $4.05 \mathrm{E}+02$ & $3.84 \mathrm{~F}$ & $3.84 E+02$ \\
\hline $241-$ & $69 \mathrm{E}+01$ & 2.81 & $2.51 \mathrm{E}+01$ & $3.88 \mathrm{E}+01$ & $4.07 \mathrm{E}+01$ & $3.61 \mathrm{E}+01$ \\
\hline $241-$ & $3.94 \mathrm{E}+04$ & 3.461 & $3.46 \mathrm{E}+04$ & $6.12 \mathrm{E}+04$ & $5.37 \mathrm{E}+04$ & $5.37 \mathrm{E}+04$ \\
\hline 241 & $5.18 \mathrm{E}$ & 5.18 & $5.18 \mathrm{E}+02$ & $7.13 \mathrm{E}+02$ & 7.13 & $7.13 \mathrm{E}+02$ \\
\hline 241 & $3.73 \mathrm{E}+02$ & 3.59 & $3.54 \mathrm{E}+02$ & $4.86 \mathrm{E}+02$ & 4.641 & $4.56 \mathrm{E}+02$ \\
\hline & $1.41 \mathrm{E}+03$ & 1.41 & $1.41 \mathrm{E}+03$ & $2.10 \mathrm{E}+03$ & 2.10 & $2.10 \mathrm{E}+03$ \\
\hline & $2.17 \mathrm{E}+03$ & $2.17 \mathrm{E}+03$ & $2.17 \mathrm{E}+03$ & $3.28 \mathrm{E}+03$ & +03 & $3.28 \mathrm{E}+03$ \\
\hline $241-1$ & $4.17 \mathrm{E}+02$ & $4.05 \mathrm{E}+02$ & $3.79 \mathrm{E}+02$ & $6.16 \mathrm{E}+02$ & $5.98 \mathrm{E}+02$ & $5.58 \mathrm{E}+02$ \\
\hline $241-1$ & $1.66 \mathrm{E}+02$ & $1.67 \mathrm{E}+02$ & $1.61 \mathrm{E}+02$ & $2.02 \mathrm{E}+02$ & $2.04 \mathrm{E}+02$ & $1.94 \mathrm{E}+02$ \\
\hline $241-\mathrm{U}-109$ & $1.26 \mathrm{E}+02$ & $1.32 \mathrm{E}+02$ & $1.25 \mathrm{E}+02$ & $1.50 \mathrm{E}+02$ & $1.60 \mathrm{E}+02$ & $1.48 \mathrm{E}+02$ \\
\hline $241-U-110$ & $1.58 \mathrm{E}+03$ & $1.30 \mathrm{E}+03$ & $1.02 \mathrm{E}+03$ & $2.35 \mathrm{E}+03$ & $1.92 \mathrm{E}+03$ & $1.47 \mathrm{E}+03$ \\
\hline
\end{tabular}

B-2 
HNF-4534 Rev. 1

Table B-2. ULD SST Liquid Samples (Sv/L)

\begin{tabular}{|c|c|c|c|c|c|c|}
\hline \multirow[b]{2}{*}{ Imk } & & \multicolumn{2}{|l|}{ TERP 68 } & \multicolumn{3}{|c|}{ IORPTI } \\
\hline & UY D.MI & VTOBM & KE1 D NA & MUD UI & WLo & YUDKM \\
\hline $241-\mathrm{A}-101$ & $9.37 \mathrm{E}+01$ & $1.04 \mathrm{E}+02$ & $8.82 \mathrm{E}+01$ & $6.96 \mathrm{E}+01$ & $8.58 \mathrm{E}+01$ & $6.11 \mathrm{E}+01$ \\
\hline $241-\mathrm{AX}-101$ & NA & $1.21 \mathrm{E}+02$ & $9.82 \mathrm{E}+01$ & NA & $1.04 \mathrm{E}+02$ & $6.76 \mathrm{E}+01$ \\
\hline 241-BY-103 & NA & $3.58 \mathrm{E}+01$ & $3.51 \mathrm{E}+01$ & NA & $2.53 \mathrm{E}+01$ & $2.42 \mathrm{E}+01$ \\
\hline 241-BY-105 & $8.14 \mathrm{E}+01$ & $6.83 \mathrm{E}+01$ & $6.12 \mathrm{E}+01$ & $8.38 \mathrm{E}+01$ & $6.33 \mathrm{E}+01$ & $5.23 \mathrm{E}+01$ \\
\hline $241-\mathrm{BY}-106$ & NA & $6.45 \mathrm{E}+01$ & $5.14 \mathrm{E}+01$ & NA & $5.58 \mathrm{E}+01$ & $3.53 \mathrm{E}+01$ \\
\hline $241-C-106$ & $1.12 \mathrm{E}+03$ & $1.12 \mathrm{E}+03$ & $1.12 \mathrm{E}+03$ & $1.72 \mathrm{E}+03$ & $1.72 \mathrm{E}+03$ & $1.72 \mathrm{E}+03$ \\
\hline $241-C-110$ & $3.21 \mathrm{E}+00$ & $2.18 \mathrm{E}+00$ & $1.73 \mathrm{E}+00$ & $4.15 \mathrm{E}+00$ & $2.55 \mathrm{E}+00$ & $1.85 \mathrm{E}+\infty$ \\
\hline 241-S-102 & $9.36 \mathrm{E}+01$ & $9.37 \mathrm{E}+01$ & $8.20 \mathrm{E}+01$ & $7.57 \mathrm{E}+01$ & +01 & $5.76 \mathrm{E}+01$ \\
\hline $241-S$ & $9.22 \mathrm{E}+01$ & $9.22 \mathrm{E}+01$ & $9.22 \mathrm{E}+01$ & $6.47 \mathrm{E}+01$ & +01 & $6.47 \mathrm{E}+01$ \\
\hline $241-S$ & $6.86 \mathrm{E}+01$ & $7.25 \mathrm{E}+01$ & $6.72 \mathrm{E}+01$ & $4.92 \mathrm{E}+01$ & +01 & $4.69 \mathrm{E}+01$ \\
\hline $241-S$ & $8.49 \mathrm{E}+01$ & $8.93 \mathrm{E}+01$ & $8.09 \mathrm{E}+01$ & $6.42 \mathrm{E}+01$ & 01 & $5.78 \mathrm{E}+01$ \\
\hline $241-S-111$ & $6.86 \mathrm{E}+01$ & $2.96 \mathrm{E}+02$ & $6.85 \mathrm{E}+01$ & $4.74 \mathrm{E}+01$ & & $4.73 E+01$ \\
\hline 241-SX-101 & $9.79 \mathrm{E}+02$ & $2.45 \mathrm{E}+02$ & $2.32 \mathrm{E}+02$ & $1.44 E+03$ & & $E+02$ \\
\hline $241-\mathrm{SX}-102$ & $1.15 \mathrm{E}+02$ & $1.18 \mathrm{E}+02$ & $1.11 \mathrm{E}+02$ & $8.44 E+01$ & & $E+01$ \\
\hline $241-S X-103$ & $1.22 \mathrm{E}+02$ & $1.27 \mathrm{E}+02$ & $1.14 \mathrm{E}+02$ & $9.57 \mathrm{E}+01$ & +02 & $E+01$ \\
\hline $241-S X-104$ & $7.03 E+01$ & $7.62 \mathrm{E}+02$ & $7.02 \mathrm{E}+01$ & $4.83 \mathrm{E}+01$ & & +01 \\
\hline $241-S X-105$ & $1.03 \mathrm{E}+02$ & $1.02 \mathrm{E}+02$ & $1.02 \mathrm{E}+02$ & $7.78 \mathrm{E}+01$ & 7.5 & +01 \\
\hline 241-SX-106 & $9.83 \mathrm{E}+01$ & $9.77 \mathrm{E}+01$ & $9.52 \mathrm{E}+01$ & $7.15 E+01$ & 7.07 & $6.67 \mathrm{E}+01$ \\
\hline $241-\mathrm{T}-107$ & $8.59 \mathrm{E}+00$ & $8.59 \mathrm{E}+00$ & $8.59 \mathrm{E}+00$ & $1.15 \mathrm{E}+01$ & $1.15 \mathrm{E}+01$ & $1.15 E+01$ \\
\hline $241-\mathrm{T}-110$ & $1.11 \mathrm{E}-01$ & $1.11 \mathrm{E}-01$ & $1.11 \mathrm{E}-01$ & $1.71 \mathrm{E}-01$ & $1.71 \mathrm{E}-01$ & $1.71 \mathrm{E}-01$ \\
\hline $241-$ & $1.41 \mathrm{E}+02$ & $1.41 \mathrm{E}+02$ & $1.41 \mathrm{E}+02$ & $1.22 \mathrm{E}+02$ & $1.22 \mathrm{E}+02$ & $1.22 \mathrm{E}+02$ \\
\hline $241-$ & $1.59 \mathrm{E}+02$ & $1.58 \mathrm{E}+02$ & $1.52 \mathrm{E}+02$ & $1.43 \mathrm{E}+02$ & $1.41 \mathrm{E}+02$ & $1.32 \mathrm{E}+02$ \\
\hline 241-U-105 & $1.74 \mathrm{E}+02$ & $1.74 \mathrm{E}+02$ & $1.74 \mathrm{E}+02$ & $1.77 \mathrm{E}+02$ & $1.77 \mathrm{E}+02$ & $1.77 \mathrm{E}+02$ \\
\hline 241-U-107 & $9.97 \mathrm{E}+01$ & $9.79 E+01$ & $9.13 \mathrm{E}+01$ & $7.91 \mathrm{E}+01$ & $7.63 \mathrm{E}+01$ & $6.60 \mathrm{E}+01$ \\
\hline $241-\mathrm{I}$ & $1.13 \mathrm{E}+02$ & $1.14 \mathrm{E}+02$ & $1.05 \mathrm{E}+02$ & $8.61 E+01$ & $8.76 \mathrm{E}+01$ & $7.37 \mathrm{E}+01$ \\
\hline 241-U-109 & $9.30 \mathrm{E}+01$ & $9.98 \mathrm{E}+01$ & $9.21 \mathrm{E}+01$ & $6.54 \mathrm{E}+01$ & $7.60 \mathrm{E}+01$ & $6.40 \mathrm{E}+01$ \\
\hline
\end{tabular}

B-3 
HNF-4534 Rev. 1

Table B-3. ULD DST Solid Samples (Sv/L)

\begin{tabular}{|l|l|l|l|l|l|l|}
\hline Tank & \multicolumn{7}{|c|}{ CoRA 68} & & & URR \\
\hline $241-\mathrm{AN}-102$ & $1.26 \mathrm{E}+03$ & $1.26 \mathrm{E}+03$ & $1.26 \mathrm{E}+03$ & $1.80 \mathrm{E}+03$ & $1.80 \mathrm{E}+03$ & $1.80 \mathrm{E}+03$ \\
\hline $241-\mathrm{AN}-103$ & $1.34 \mathrm{E}+02$ & $1.35 \mathrm{E}+02$ & $1.11 \mathrm{E}+02$ & $1.20 \mathrm{E}+02$ & $1.22 \mathrm{E}+02$ & $8.37 \mathrm{E}+01$ \\
\hline $241-\mathrm{AN}-104$ & $2.70 \mathrm{E}+02$ & $3.11 \mathrm{E}+02$ & $2.42 \mathrm{E}+02$ & $2.77 \mathrm{E}+02$ & $3.41 \mathrm{E}+02$ & $2.34 \mathrm{E}+02$ \\
\hline $241-\mathrm{AN}-105$ & $1.89 \mathrm{E}+02$ & $1.83 \mathrm{E}+02$ & $1.72 \mathrm{E}+02$ & $1.88 \mathrm{E}+02$ & $1.79 \mathrm{E}+02$ & $1.62 \mathrm{E}+02$ \\
\hline $241-\mathrm{AN}-107$ & $2.25 \mathrm{E}+03$ & $2.25 \mathrm{E}+03$ & $2.25 \mathrm{E}+03$ & $3.27 \mathrm{E}+03$ & $3.27 \mathrm{E}+03$ & $3.27 \mathrm{E}+03$ \\
\hline $241-\mathrm{AW}-101$ & $3.02 \mathrm{E}+02$ & $2.32 \mathrm{E}+02$ & $2.24 \mathrm{E}+02$ & $3.58 \mathrm{E}+02$ & $2.49 \mathrm{E}+02$ & $2.36 \mathrm{E}+02$ \\
\hline $241-\mathrm{AW}-102$ & $5.39 \mathrm{E}+03$ & $5.39 \mathrm{E}+03$ & $5.39 \mathrm{E}+03$ & $7.89 \mathrm{E}+03$ & $7.89 \mathrm{E}+03$ & $7.89 \mathrm{E}+03$ \\
\hline $241-\mathrm{AW}-105$ & $3.13 \mathrm{E}+03$ & $3.13 \mathrm{E}+03$ & $3.13 \mathrm{E}+03$ & $4.81 \mathrm{E}+03$ & $4.81 \mathrm{E}+03$ & $4.81 \mathrm{E}+03$ \\
\hline $241-\mathrm{AW}-106$ & $4.68 \mathrm{E}+02$ & $4.68 \mathrm{E}+02$ & $4.68 \mathrm{E}+02$ & $6.73 \mathrm{E}+02$ & $6.73 \mathrm{E}+02$ & $6.73 \mathrm{E}+02$ \\
\hline $241-\mathrm{AY}-101$ & $1.52 \mathrm{E}+04$ & $1.52 \mathrm{E}+04$ & $1.52 \mathrm{E}+04$ & $2.04 \mathrm{E}+04$ & $2.04 \mathrm{E}+04$ & $2.04 \mathrm{E}+04$ \\
\hline $241-\mathrm{AY}-102$ & $1.82 \mathrm{E}+05$ & $1.82 \mathrm{E}+05$ & $1.82 \mathrm{E}+05$ & $2.30 \mathrm{E}+05$ & $2.30 \mathrm{E}+05$ & $2.30 \mathrm{E}+05$ \\
\hline $241-\mathrm{AZ}-102$ & $1.10 \mathrm{E}+05$ & $1.10 \mathrm{E}+05$ & $1.10 \mathrm{E}+05$ & $1.64 \mathrm{E}+05$ & $1.64 \mathrm{E}+05$ & $1.64 \mathrm{E}+05$ \\
\hline $241-\mathrm{SY}-101$ & $8.70 \mathrm{E}+02$ & $8.42 \mathrm{E}+02$ & $8.08 \mathrm{E}+02$ & $1.22 \mathrm{E}+03$ & $1.17 \mathrm{E}+03$ & $1.12 \mathrm{E}+03$ \\
\hline $241-\mathrm{SY}-102$ & $3.94 \mathrm{E}+04$ & $3.94 \mathrm{E}+04$ & $3.94 \mathrm{E}+04$ & $6.14 \mathrm{E}+04$ & $6.14 \mathrm{E}+04$ & $6.14 \mathrm{E}+04$ \\
\hline $241-\mathrm{SY}-103$ & $1.64 \mathrm{E}+03$ & $1.10 \mathrm{E}+03$ & $8.72 \mathrm{E}+02$ & $2.46 \mathrm{E}+03$ & $1.63 \mathrm{E}+03$ & $1.27 \mathrm{E}+03$ \\
\hline
\end{tabular}

B-4 
HNF-4534 Rev. 1

Table B-4. ULD DST Liquid Samples (Sv/L)

\begin{tabular}{|c|c|c|c|c|c|c|}
\hline \multirow{2}{*}{ Tank } & \multicolumn{3}{|c|}{ TGRP 68} & \multicolumn{3}{|c|}{ ICRP $/ 1$} \\
\hline & WMDMI & UTDMV & OTD.M3. & UTD MT & TUDMM & UWDWE \\
\hline 241-AN-101 & +01 & & & & & \\
\hline & $78 \mathrm{E}+02$ & & & $73 \mathrm{E}+02$ & & \\
\hline & & & & $30 \mathrm{E}+02$ & & \\
\hline 24 & +02 & & & $1.32 \mathrm{E}+02$ & & +02 \\
\hline 241 & +02 & & +02 & $1.16 \mathrm{E}+02$ & & +01 \\
\hline 241 & +03 & & +03 & +03 & & +03 \\
\hline 241 & +01 & 4.2 & t01 & +01 & & 2.76 \\
\hline 241 & 5.801 & & $\mathrm{HOI}$ & $4.11 \mathrm{E}+01$ & & 4.11 \\
\hline $241-$ & 3.371 & & $E+01$ & $3.89 \mathrm{E}+01$ & & $3.89 \mathrm{E}+01$ \\
\hline $241-$ & $1.68 \mathrm{E}+00$ & 1.6 & $1.68 \mathrm{E}+00$ & $1.51 \mathrm{E}+\infty$ & & $1.51 \mathrm{E}+00$ \\
\hline $241-1$ & $6.31 \mathrm{E}+01$ & 5.98 & $5.37 E+01$ & $5.29 \mathrm{E}+01$ & & $3.81 \mathrm{E}+01$ \\
\hline $241-A$ & $1.04 \mathrm{E}+01$ & 1.0 & $1.02 \mathrm{E}+01$ & $7.60 \mathrm{E}+00$ & & $7.26 \mathrm{E}+00$ \\
\hline $241-A$ & $8.39 \mathrm{E}+00$ & 8.89 & $6.73 \mathrm{E}+00$ & $6.51 \mathrm{E}+00$ & & $4.74 \mathrm{E}+00$ \\
\hline $241-A$ & $1.79 \mathrm{E}+01$ & +01 & $1.79 \mathrm{E}+01$ & $1.25 \mathrm{E}+01$ & +01 & $1.25 \mathrm{E}+01$ \\
\hline $241-\mathrm{A}$ & $1.24 \mathrm{E}+02$ & +02 & +02 & $9.28 \mathrm{E}+01$ & +02 & $8.10 \mathrm{E}+01$ \\
\hline $241-\mathrm{A}$ & $1.01 \mathrm{E}+01$ & 1.04 & $9.16 \mathrm{E}+00$ & $8.16 \mathrm{E}+\infty 0$ & +00 & $6.68 \mathrm{E}+00$ \\
\hline $241-\mathrm{AW}-103$ & NA & 5.62 & $5.11 \mathrm{E}+00$ & NA & +00 & $3.51 \mathrm{E}+00$ \\
\hline $241-\mathrm{AW}-104$ & $6.52 \mathrm{E}+00$ & $7.29 \mathrm{E}+00$ & $4.82 \mathrm{E}+00$ & $7.30 \mathrm{E}+00$ & $8.50 \mathrm{E}+00$ & $4.65 \mathrm{E}+00$ \\
\hline 241-AW & $5.53 \mathrm{E}+00$ & $4.66 \mathrm{E}+00$ & $4.59 \mathrm{E}+00$ & $5.54 \mathrm{E}+\infty 0$ & 4.191 & $4.07 \mathrm{E}+00$ \\
\hline $241-$ & $7.72 \mathrm{E}+01$ & $6.11 E+01$ & $5.27 \mathrm{E}+01$ & $8.00 \mathrm{E}+01$ & +01 & 4.17E+01 \\
\hline 241- & $9.48 \mathrm{E}+01$ & 8.80 & +01 & $1.28 \mathrm{E}+02$ & -02 & $1.16 \mathrm{E}+02$ \\
\hline 241 & $2.84 \mathrm{E}$ & 2.4 & $+\infty$ & $3.12 \mathrm{E}+00$ & & $2.45 \mathrm{E}+00$ \\
\hline & $4.62 \mathrm{E}$ & 4.62 & 4.62 & $3.76 \mathrm{E}+02$ & -02 & $3.76 \mathrm{E}+02$ \\
\hline & $3.59 \mathrm{E}+02$ & 3.42 & 2.98 & $3.27 \mathrm{E}$ & & $2.32 \mathrm{E}+02$ \\
\hline & $2.88 \mathrm{E}+02$ & 2.88 & $2.88 \mathrm{E}+02$ & $2.34 \mathrm{E}+02$ & +02 & $2.34 \mathrm{E}+02$ \\
\hline & $2.61 \mathrm{E}+01$ & 3.10 & $2.38 \mathrm{E}+01$ & $2.88 \mathrm{E}+01$ & -01 & $2.52 \mathrm{E}+01$ \\
\hline $241-$ & $1.04 \mathrm{E}+02$ & $1.04 \mathrm{E}+02$ & $1.04 \mathrm{E}+02$ & $7.48 \mathrm{E}+01$ & & $7.48 \mathrm{E}+01$ \\
\hline
\end{tabular}

B-5 
RPP-5924 REV 0

HNF-4534 Rev. 1

This page intentionally left blank.

B-6

C-52 


\section{HNF-4534 Rev. 1}

\section{APPENDIX C}

\section{C.0 COMPARISON OF ANALYTE AND ULD MEANS AND VARIANCES}

Tables $\mathrm{C}-1$ and $\mathrm{C}-2$ are a comparison of the means and variances of radionuclide activity $(\mu \mathrm{Ci} / \mathrm{g}$ or $\mu \mathrm{Ci} / \mathrm{L}$ ) and the ULDs (Sv/L) for the three models (M1, M2, and $\mathrm{M} 3$ ) for using below detection limit observations. M1, M2, and M3 denote the models. They denote the cases when the below detection limit observations are omitted, replaced by the detection limit, and replaced by zero, respectively. Num. Tanks are the total number of tanks with a radionuclide mean or a ULD.

In Table C-1, for a given model, the first Num.Tanks value is the total number of tanks with an analyte mean. The second Num. Tanks value is the number of tanks with the radionuclide mean used in the ULD. For each model, the means and variances (by analyte and waste type) are not significantly different from each other.

In Table C-2, the Num. Tanks denotes the number of tanks with analyte means used to compute the ULD based on the three modes for using observations below the detection limit. For each waste type, the ULD means and variance for the three models are not significantly different from each other.

Table C-3 lists the quantiles corresponding to the $95^{\mathrm{t}}$ and $99^{\circ}$ percentiles points and $95 / 95$ and 95/99 tolerance limits based on the lognormal distribution for the three models for using observations below detection limits. 
Table C-1. Comparison of Means $(\mu \mathrm{Ci} / \mathrm{g})$ and Variances $\left(\mu \mathrm{Ci} / \mathrm{g}^{2}\right)$ by Radionuclide and Waste Type for the Three Models ( M1, M2, and M3) for Detection Limits (2 sheets)

\begin{tabular}{|c|c|c|c|c|c|c|c|}
\hline Analyte & Model & $\begin{array}{l}\text { Nom. } \\
\text { Tinnks }\end{array}$ & Mean & Variance & $\begin{array}{l}\text { Nom: } \\
\text { Tankis: }\end{array}$ & Mein. & Horrance \\
\hline \multirow{2}{*}{\multicolumn{2}{|c|}{ 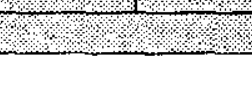 }} & \multicolumn{3}{|c|}{ DCF ICRP-65 } & \multicolumn{3}{|c|}{ 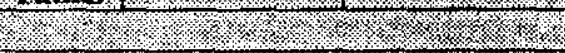 } \\
\hline & & \multicolumn{3}{|c|}{ SST Solid Samples, nCUr } & \multicolumn{3}{|c|}{ SST Gquíd SAmples, $1 \mathrm{CH}$} \\
\hline \multirow[t]{6}{*}{${ }^{137} \mathrm{Cs}$} & \multirow[t]{2}{*}{ M1 } & 58 & $1.06 \mathrm{E}+02$ & $1.51 \mathrm{E}+04$ & 28 & $2.76 \mathrm{E}+05$ & $2.41 \mathrm{E}+10$ \\
\hline & & 54 & $1.10 \mathrm{E}+02$ & $1.59 \mathrm{E}+04$ & 23 & $3.04 E+05$ & $2.04 \mathrm{E}+10$ \\
\hline & \multirow[t]{2}{*}{ M2 } & 61 & $1.01 \mathrm{E}+02$ & $1.48 \mathrm{E}+04$ & 28 & $2.76 \mathrm{E}+05$ & $2.42 \mathrm{E}+10$ \\
\hline & & 54 & $1.10 \mathrm{E}+02$ & $1.59 \mathrm{E}+04$ & 23 & $3.04 \mathrm{E}+05$ & $2.04 \mathrm{E}+10$ \\
\hline & \multirow[t]{2}{*}{ M3 } & 61 & $1.01 \mathrm{E}+02$ & $1.49 \mathrm{E}+04$ & 28 & $2.76 \mathrm{E}+05$ & $2.42 E+10$ \\
\hline & & 54 & $1.10 \mathrm{E}+02$ & $1.59 \mathrm{E}+04$ & 23 & $3.04 \mathrm{E}+05$ & $2.04 \mathrm{E}+10$ \\
\hline \multirow[t]{6}{*}{$\mathrm{GA}$} & \multirow[t]{2}{*}{$\mathrm{Ml}$} & 105 & $1.21 \mathrm{E}+00$ & $1.07 \mathrm{E}+01$ & 43 & $9.13 E+01$ & $7.39 \mathrm{E}+04$ \\
\hline & & 54 & $1.35 \mathrm{E}+00$ & $1.52 \mathrm{E}+01$ & 23 & $8.94 \mathrm{E}+01$ & $6.99 \mathrm{E}+04$ \\
\hline & \multirow[t]{2}{*}{ M2 } & 109 & $1.14 \mathrm{E}+00$ & $9.29 \mathrm{E}+00$ & 54 & $7.74 \mathrm{E}+01$ & $5.56 \mathrm{E}+04$ \\
\hline & & 54 & $1.30 \mathrm{E}+00$ & $1.31 \mathrm{E}+01$ & 23 & $9.75 \mathrm{E}+01$ & $5.95 \mathrm{E}+04$ \\
\hline & \multirow[t]{2}{*}{ M3 } & 109 & $1.12 \mathrm{E}+00$ & $9.31 \mathrm{E}+00$ & 54 & $5.74 \mathrm{E}+01$ & $4.94 \mathrm{E}+04$ \\
\hline & & 54 & $1.29 \mathrm{E}+00$ & $1.31 \mathrm{E}+01$ & 23 & $5.55 \mathrm{E}+01$ & $4.49 \mathrm{E}+04$ \\
\hline \multirow[t]{6}{*}{${ }^{\infty 0} \mathrm{Sr}$} & \multirow[t]{2}{*}{ M1 } & 58 & $7.01 \mathrm{E}+02$ & $6.80 \mathrm{E}+06$ & 27 & $1.82 \mathrm{E}+03$ & $2.76 \mathrm{E}+07$ \\
\hline & & 54 & $7.01 \mathrm{E}+02$ & $7.20 \mathrm{E}+06$ & 23 & $2.10 \mathrm{E}+03$ & $3.21 \mathrm{E}+07$ \\
\hline & \multirow[t]{2}{*}{ M2 } & 58 & $7.01 \mathrm{E}+02$ & $6.80 \mathrm{E}+06$ & 27 & $1.82 \mathrm{E}+03$ & $2.76 \mathrm{E}+07$ \\
\hline & & 54 & $7.01 E+02$ & $7.20 \mathrm{E}+06$ & 23 & $2.10 \mathrm{E}+03$ & $3.21 \mathrm{E}+07$ \\
\hline & \multirow[t]{2}{*}{ M3 } & 58 & $7.01 \mathrm{E}+02$ & $6.80 \mathrm{E}+06$ & 27 & $1.82 \mathrm{E}+03$ & $2.76 \mathrm{E}+07$ \\
\hline & & 54 & $7.01 \mathrm{E}+02$ & $7.20 \mathrm{E}+06$ & 23 & $2.10 \mathrm{E}+03$ & $3.21 \mathrm{E}+07$ \\
\hline & & \multicolumn{3}{|c|}{ DST Solid Samples, $1 \mathrm{CU} / \mathrm{g}$} & \multicolumn{3}{|c|}{ DST Lquid Samples, $\mu \mathrm{CT}$. } \\
\hline \multirow[t]{6}{*}{${ }^{137} \mathrm{Cs}$} & \multirow[t]{2}{*}{ M1 } & 15 & $2.43 \mathrm{E}+02$ & $3.53 \mathrm{E}+04$ & 27 & $3.11 \mathrm{E}+05$ & $1.57 \mathrm{E}+11$ \\
\hline & & 15 & $2.43 E+02$ & $3.53 \mathrm{E}+04$ & 26 & $3.23 E+05$ & $1.60 E+11$ \\
\hline & \multirow[t]{2}{*}{ M2 } & 15 & $2.43 \mathrm{E}+02$ & $3.53 \mathrm{E}+04$ & 27 & $3.11 \mathrm{E}+05$ & $1.57 \mathrm{E}+11$ \\
\hline & & 15 & $2.43 \mathrm{E}+02$ & $3.53 \mathrm{E}+04$ & 26 & $3.22 \mathrm{E}+05$ & $1.60 \mathrm{E}+11$ \\
\hline & \multirow[t]{2}{*}{ M3 } & 15 & $2.43 \mathrm{E}+02$ & $3.53 \mathrm{E}+04$ & 27 & $3.11 \mathrm{E}+05$ & $1.57 \mathrm{E}+11$ \\
\hline & & 15 & $2.43 \mathrm{E}+02$ & $3.53 \mathrm{E}+04$ & 26 & $3.22 \mathrm{E}+05$ & $1.60 \mathrm{E}+11$ \\
\hline \multirow[t]{6}{*}{$\mathrm{GA}$} & \multirow[t]{2}{*}{$\mathbf{M} 1$} & 19 & $1.02 \mathrm{E}+01$ & $4.79 \mathrm{E}+02$ & 27 & $5.29 \mathrm{E}+01$ & $2.48 \mathrm{E}+04$ \\
\hline & & 15 & $7.35 \mathrm{E}+00$ & $2.24 \mathrm{E}+02$ & 26 & $5.49 \mathrm{E}+01$ & $2.57 \mathrm{E}+04$ \\
\hline & \multirow[t]{2}{*}{ M2 } & 19 & $1.02 \mathrm{E}+01$ & $4.80 \mathrm{E}+02$ & 28 & $5.01 \mathrm{E}+01$ & $2.39 \mathrm{E}+04$ \\
\hline & & 15 & $7.33 \mathrm{E}+00$ & $2.24 \mathrm{E}+02$ & 26 & $5.37 \mathrm{E}+01$ & $2.56 \mathrm{E}+04$ \\
\hline & $\mathrm{M3}$ & 19 & $1.02 \mathrm{E}+01$ & $4.80 \mathrm{E}+02$ & 28 & $4.41 \mathrm{E}+01$ & $2.42 \mathrm{E}+04$ \\
\hline & & 15 & $7.31 \mathrm{E}+00$ & $2.24 \mathrm{E}+02$ & 26 & $4.75 \mathrm{E}+01$ & $2.60 \mathrm{E}+04$ \\
\hline${ }^{90} \mathrm{Sr}$ & MI & 15 & $6.13 \mathrm{E}+03$ & $3.88 \mathrm{E}+08$ & 27 & $7.41 E+03$ & $6.12 \mathrm{E}+08$ \\
\hline & & 15 & $6.13 E+03$ & $3.88 \mathrm{E}+08$ & 26 & $7.69 \mathrm{E}+03$ & $6.34 \mathrm{E}+08$ \\
\hline & M2 & 15 & $6.13 \mathrm{E}+03$ & $3.88 \mathrm{E}+08$ & 27 & $7.41 \mathrm{E}+03$ & $6.12 \mathrm{E}+08$ \\
\hline & & 15 & $6.13 E+03$ & $3.88 \mathrm{E}+08$ & 26 & $7.69 \mathrm{E}+03$ & $6.34 \mathrm{E}+08$ \\
\hline & M3 & 15 & $6.13 \mathrm{E}+03$ & $3.88 \mathrm{E}+08$ & 27 & $7.41 \mathrm{E}+03$ & $6.12 \mathrm{E}+08$ \\
\hline
\end{tabular}

C-2 
HNF-4534 Rev, I

Table C-1. Comparison of Means $(\mu \mathrm{Ci} / \mathrm{g})$ and Variances $\left(\mu \mathrm{Ci} / \mathrm{g}^{2}\right)$ by Radionuclide and Waste Type for the Three Models ( M1, M2, and M3) for Detection Limits (2 sheets)

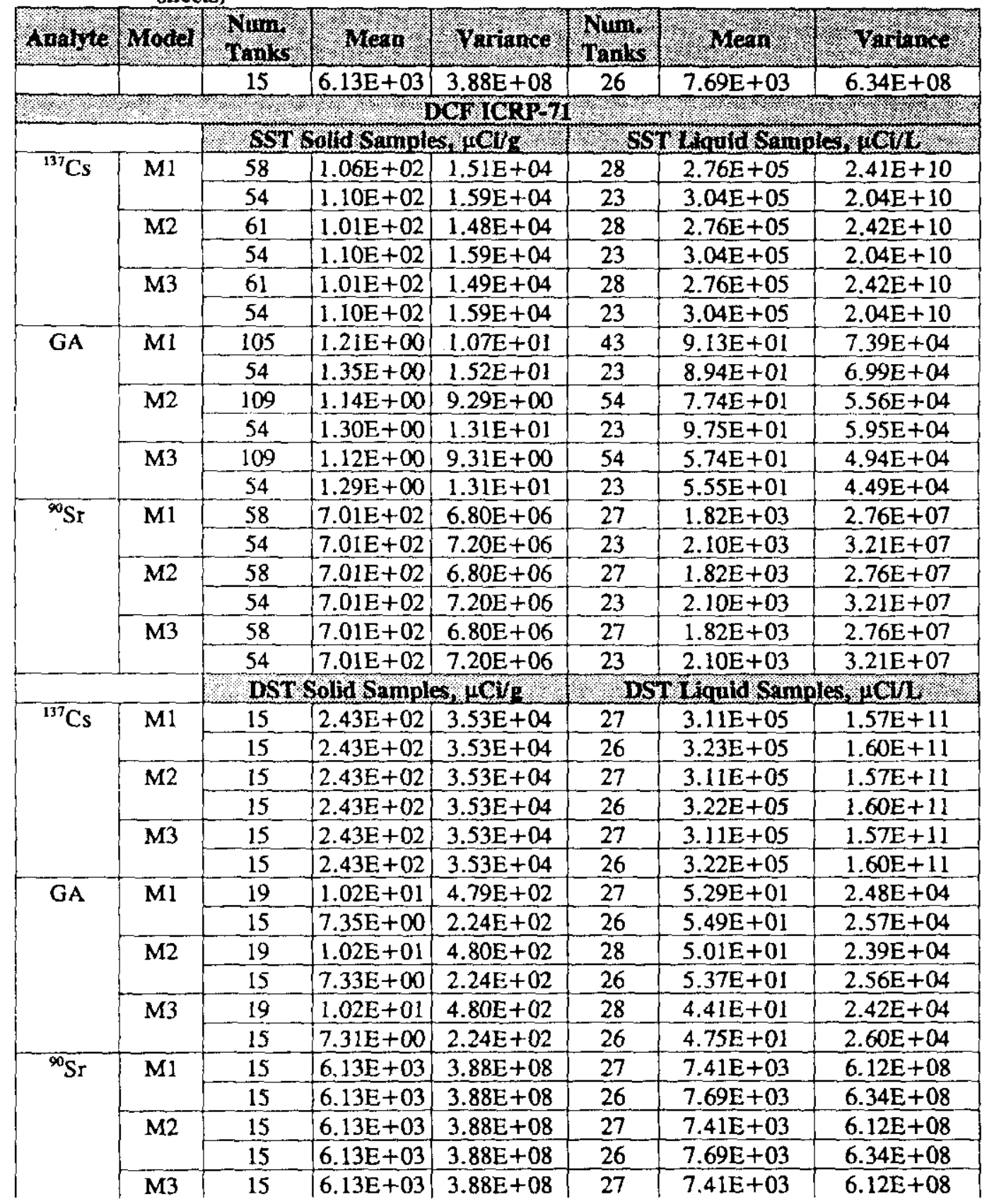

C-3 


\section{HNF-4534 Rev, 1}

Table C-1. Comparison of Means $(\mu \mathrm{Ci} / \mathrm{g})$ and Variances $\left(\mu \mathrm{Ci} / \mathrm{g}^{2}\right)$ by Radionuclide and Waste Type for the Three Models ( M1, M2, and M3) for Detection Limits (2 sheets)

\begin{tabular}{|c|c|c|c|c|c|c|c|}
\hline inoloto & moapl & Hink & mena & Miriance & $\begin{array}{l}\text { Num. } \\
\text { Tanks }\end{array}$ & Mean & 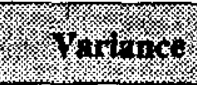 \\
\hline & & 15 & $6.13 E+03$ & $3.88 \mathrm{E}+08$ & 26 & $7.69 \mathrm{E}+03$ & $6.34 \mathrm{E}+08$ \\
\hline
\end{tabular}

C.4 
HNF-4534 Rev, 1

Table C-2. Comparison of Means (Sv/L) and Variances (Sv/ $\left.\mathrm{L}^{2}\right)$ of ULDs by Waste Type for the Three Models (M1, M2, and M3) for Detection Limits

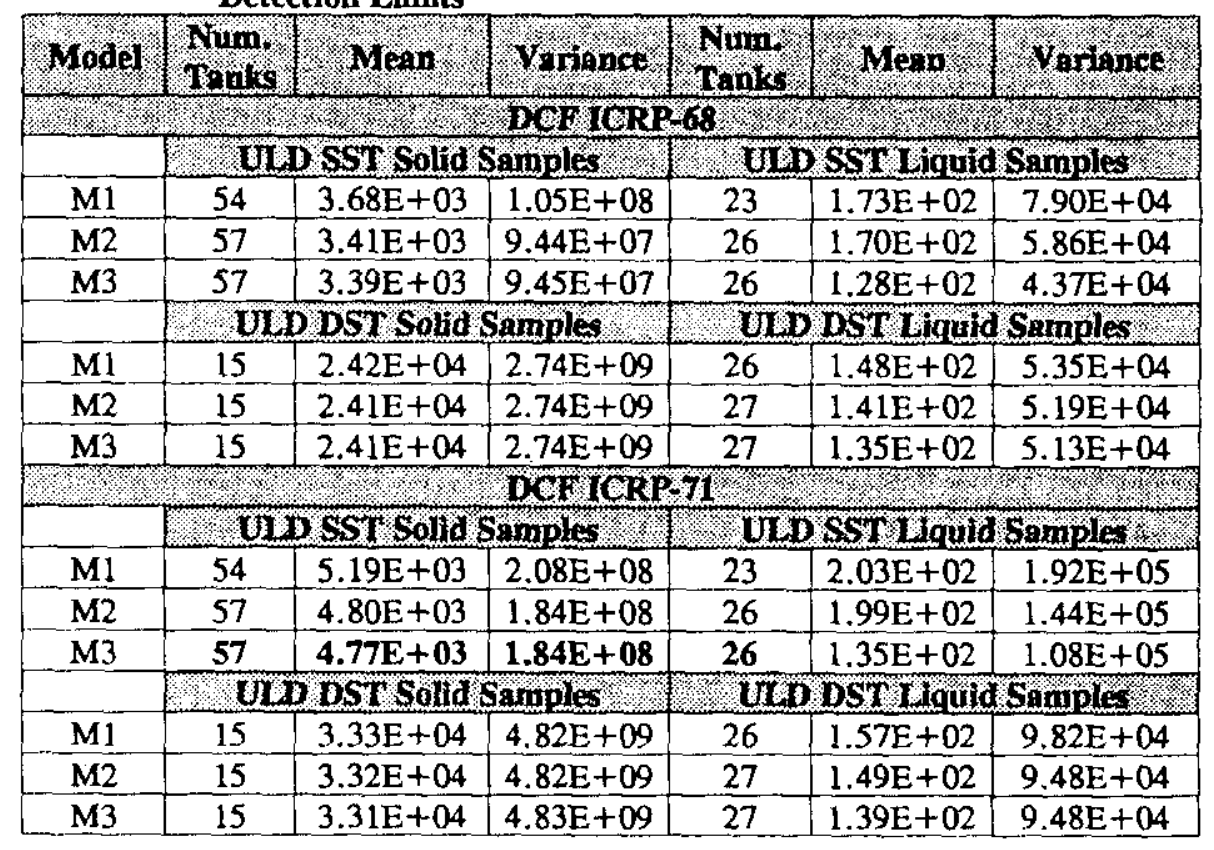

C-5 
HNF-4534 Rev. 1

Table C-3. Quantiles (Sv/L) Corresponding to the $95^{\text {th }}$ and $99^{\text {th }}$ Percentiles Points and 95/59 and 95/99 Tolerance Limits (Sv/L) for the Lognormal Distribution for the Three Models for Below Detection Limit Observations

\begin{tabular}{|c|c|c|c|c|c|}
\hline Madel & Num,Tanks & $95 \mathrm{th}$ & $99 \mathrm{th}$ & $95195 \mathrm{TU}$ & $951991 \mathrm{TL}$ \\
\hline not rok 6. & 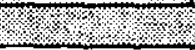 & SSW & olld Samples & SwII & 6 \\
\hline M1 & 54 & $1.06 \mathrm{E}+04$ & $3.26 \mathrm{E}+04$ & $2.06 \mathrm{E}+04$ & $7.63 \mathrm{E}+04$ \\
\hline $\mathbf{M} 2$ & 57 & $9.43 \mathrm{E}+03$ & $2.84 \mathrm{E}+04$ & $1.77 \mathrm{E}+04$ & $6.35 \mathrm{E}+04$ \\
\hline \multirow[t]{2}{*}{ M3 } & 57 & $9.53 \mathrm{E}+03$ & $2.96 \mathrm{E}+04$ & $1.82 \mathrm{E}+04$ & $6.79 E+04$ \\
\hline & \multicolumn{5}{|c|}{ SST W Wiqud Sanples SVIV } \\
\hline M1 & 23 & $1.44 \mathrm{E}+03$ & $5.01 \mathrm{E}+03$ & $5.04 \mathrm{E}+03$ & $2.51 \mathrm{E}+04$ \\
\hline M2 & 26 & $1.43 \mathrm{E}+03$ & $4.83 \mathrm{E}+03$ & $4.43 \mathrm{E}+03$ & $2.05 \mathrm{E}+04$ \\
\hline \multirow[t]{2}{*}{ M3 } & 26 & $1.01 \mathrm{E}+03$ & $3.21 \mathrm{E}+03$ & $2.95 \mathrm{E}+03$ & $1.28 \mathrm{E}+04$ \\
\hline & \multicolumn{5}{|c|}{ DST Solld Sanples, SvI } \\
\hline M1 & 15 & $1.07 \mathrm{E}+05$ & $5.09 \mathrm{E}+05$ & $8.82 \mathrm{E}+05$ & $7.84 \mathrm{E}+06$ \\
\hline $\mathbf{M} 2$ & 15 & $1.06 \mathrm{E}+05$ & $5.13 E+05$ & $8.91 E+05$ & $8.07 \mathrm{E}+06$ \\
\hline \multirow[t]{2}{*}{ M3 } & 15 & $1.09 \mathrm{E}+05$ & $5.44 \mathrm{E}+05$ & $9.57 \mathrm{E}+05$ & $9.08 \mathrm{E}+06$ \\
\hline & \multicolumn{5}{|c|}{ DST Lquid Samples, SVIL } \\
\hline Ml & 26 & $7.97 \mathrm{E}+02$ & $2.53 \mathrm{E}+03$ & $2.33 \mathrm{E}+03$ & $1.00 \mathrm{E}+04$ \\
\hline $\mathrm{M} 2$ & 27 & $7.54 \mathrm{E}+02$ & $2.43 \mathrm{E}+03$ & $2.18 \mathrm{E}+03$ & $9.79 \mathrm{E}+03$ \\
\hline M3 & 27 & $7.12 E+02$ & $2.32 \mathrm{E}+03$ & $2.08 E+03$ & $9.50 \mathrm{E}+03$ \\
\hline DCF ICRP 71 & \multicolumn{5}{|c|}{ SST Solid Samples, SVM } \\
\hline M1 & 54 & $1.51 E+04$ & $4.77 \mathrm{E}+04$ & $2.99 \mathrm{E}+04$ & $1.14 \mathrm{E}+05$ \\
\hline M2 & 57 & $1.35 \mathrm{E}+04$ & $4.16 \mathrm{E}+04$ & $2.57 \mathrm{E}+04$ & $9.43 \mathrm{E}+04$ \\
\hline \multirow[t]{2}{*}{ M3 } & 57 & $1.40 \mathrm{E}+04$ & $4.51 \mathrm{E}+04$ & $2.73 \mathrm{E}+04$ & $1.06 \mathrm{E}+05$ \\
\hline & \multicolumn{5}{|c|}{ SST Liquia Samples, SVI } \\
\hline M1 & 23 & $1.16 \mathrm{E}+03$ & $3.88 \mathrm{E}+03$ & $3.89 \mathrm{E}+03$ & $1.84 \mathrm{E}+04$ \\
\hline M2 & 26 & $1.27 \mathrm{E}+03$ & $4.18 \mathrm{E}+03$ & $3.84 \mathrm{E}+03$ & $1.74 \mathrm{E}+04$ \\
\hline \multirow[t]{2}{*}{ M3 } & 26 & $7.32 \mathrm{E}+02$ & $2.21 \mathrm{E}+03$ & $2.05 \mathrm{E}+03$ & $8.27 \mathrm{E}+03$ \\
\hline & \multicolumn{5}{|c|}{ DST Solid Samples, SVI } \\
\hline $\mathrm{MI}$ & 15 & $1.67 \mathrm{E}+05$ & $8.53 \mathrm{E}+05$ & $1.51 \mathrm{E}+06$ & $1.49 \mathrm{E}+07$ \\
\hline M2 & 15 & $1.65 E+05$ & $8.57 \mathrm{E}+05$ & $1.53 \mathrm{E}+06$ & $1.53 \mathrm{E}+07$ \\
\hline \multirow[t]{2}{*}{ M3 } & 15 & $1.75 \mathrm{E}+05$ & $9.57 \mathrm{E}+05$ & $1.74 \mathrm{E}+06$ & $1.88 \mathrm{E}+07$ \\
\hline & \multicolumn{4}{|c|}{ DST Lquala Samples, SvIL } & 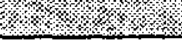 \\
\hline $\mathrm{M} 1$ & 26 & $7.68 \mathrm{E}+02$ & $2.51 \mathrm{E}+03$ & $2.31 \mathrm{E}+03$ & $1.03 \mathrm{E}+04$ \\
\hline M2 & 27 & $7.24 \mathrm{E}+02$ & $2.40 \mathrm{E}+03$ & $2.15 \mathrm{E}+03$ & $1.00 \mathrm{E}+04$ \\
\hline M3 & 27 & $6.45 E+02$ & $2.18 E+03$ & $1.94 E+03$ & $9.29 E+03$ \\
\hline
\end{tabular}

C-6 
HNF-4534 Rev. 1

\section{APPENDIX D}

\section{D.0 S-PLUS FUNCTIONS FOR COMPUTING THE ULD}

Two S-PLUS functions were written to convert $\mu \mathrm{Ci} / \mathrm{g}$ or $\mu \mathrm{Ci} / \mathrm{L}$ to $\mathrm{Sv} / \mathrm{L}$ and to the ULD. The functions are called SLD.ULD.fn, and LQD.ULD.fn. The first function is for solid samples, and the second is for liquid samples.

For each type of sample, the means for ${ }^{137} \mathrm{Cs}$, GA (gross alpha), and ${ }^{80} \mathrm{Sr}$ were stored in four S-PLUS data frames called SST.SLD.df, SST.LQD.df, DST.SLD.nu.AZ.df, and DST.LQD.nu.AZ.df. The first column of each data frame lists the name of the tank. Columns 2, 3, and 4 list the means for ${ }^{137} \mathrm{Cs}$ for each of the three models (M1, M2, and M2) for using observations below the detection limit. Likewise, columns 5, 6, and 7 list the three means for GA, and columns 8,9 , and 10 list the three means for ${ }^{90} \mathrm{Sr}$. These are the means reported in Appendix A.

The two S-PLUS functions use the conversion factors $\mathrm{Bq} / \mu \mathrm{Ci}, \mathrm{g} / \mathrm{L}$, and $\mathrm{Sv} / \mathrm{Bq}$ given in Table 1 to convert $\mu \mathrm{Ci} / \mathrm{g}$ or $\mu \mathrm{Ci} / \mathrm{L}$ to $\mathrm{Sv} / \mathrm{L}$ for each of ${ }^{137} \mathrm{Cs}, \mathrm{GA}$, and ${ }^{90} \mathrm{Sr}$. Note that there are two conversion factors for Sv/Bq, one based on ICRP-68 and the other on ICRP-71. The Sv/L values are stored in columns 11,12 , and 13 for ${ }^{137} \mathrm{Cs}$, in columns 14,15 , and 16 for $\mathrm{GA}$, and in columns 17,18 , and 19 for ${ }^{90} \mathrm{Sr}$. Note that ${ }^{90} \mathrm{Y}$ is included as a multiple of ${ }^{10} \mathrm{Sr}$. Columns 20,21 , and 22 contain the ULD for each of the three models M1, M2, and M2. The ULD is the sum of the $\mathrm{Sv} / \mathrm{L}$ for ${ }^{137} \mathrm{Cs}, \mathrm{GA}$, and ${ }^{90} \mathrm{Sr}$. The last 16 columns are then named according to the units. That is columns 11 to 13 are called "Cs.SvPL.M1", "Cs.SvPL.M2", "Cs.SvPL.M3", columns 14 to 16 are called GA.SvPL.M1", "GA.SvPL.M2", "GA.SvPL.M3", columns 17 to 19 are called SrY.SvPL.M1", "SrY.SvPL.M2", "SrY.SvPL.M3", and columns 20 to 22 are called "ULD.M1", "ULD.M2", "ULD.M3".

These two S-PLUS functions generate eight new data frames. The data frames for SSTs are called ULD.SST.ICRP68.SLD.df, ULD.SST.ICRP71.SLD.df, ULD.SST.ICRP68.LQD.df, and ULD.SST.ICRP71.LQD.df. The data frames for DSTs are ULD.DST.ICRP68.SLD.df, ULD.DST.ICRP71.SLD.df, ULD.DST.ICRP68.LQD.df, and ULD.DST.ICRP71.LQD.df. The last three columns of each data frame, without most of the missing values, e.g., the NA's, are the ULD values given in Appendix B. 
HNF-4534 Rev. 1

\section{D1.0 THE S-PLUS FUNCTION SLD.ULD.FN}

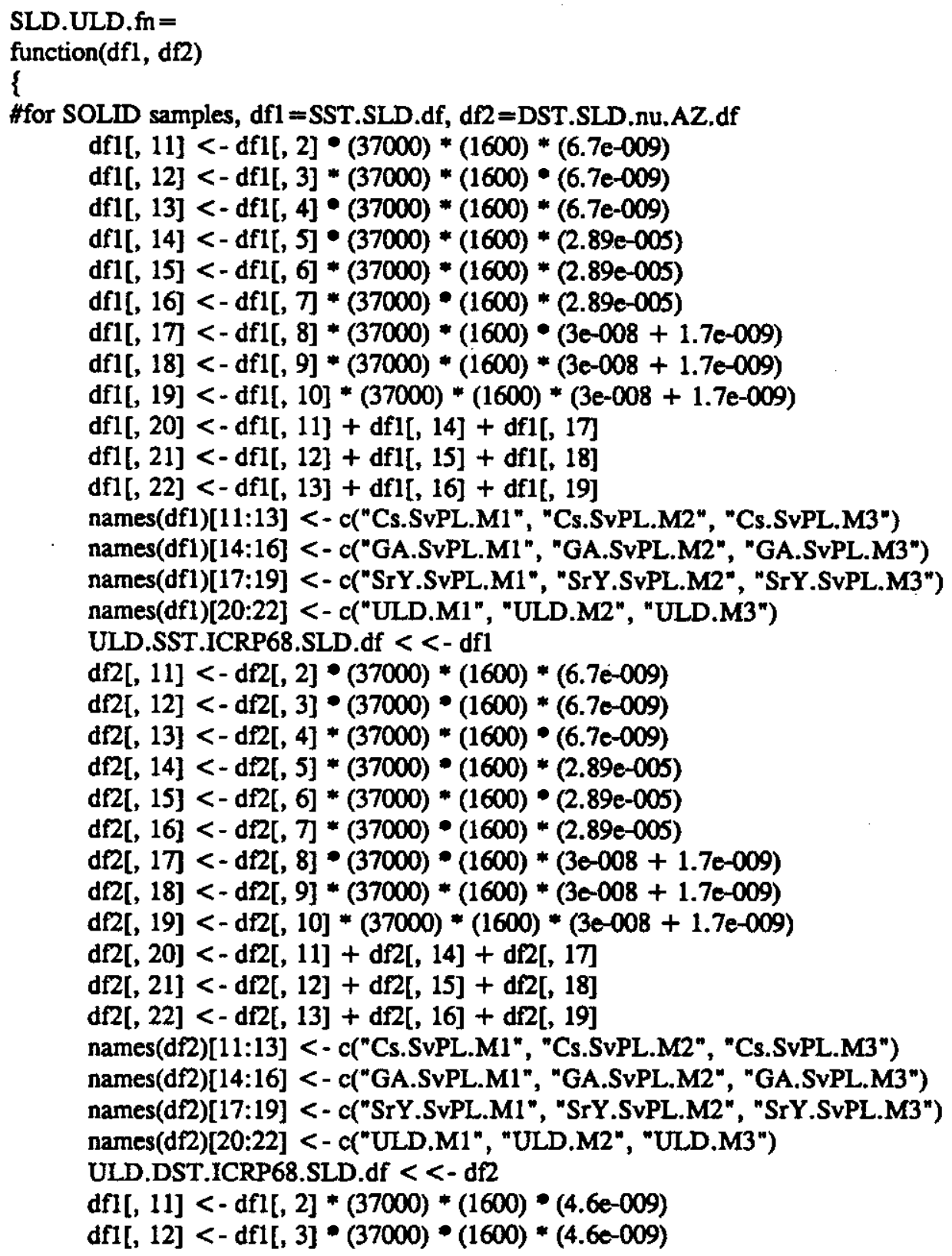

D-2 
HNF-4534 Rev. 1

\author{
df1[, 13] <- df1[, 4] $\bullet(37000) \bullet(1600) *(4.6 \mathrm{e}-009)$ \\ df1[, 14] <- df1[, 5] * (37000) * (1600)* (4.5e-005) \\ df1[, 15] <- df1[, 6] * $(37000) *(1600) *(4.5 e-005)$ \\ df1 $[, 16]<-$ df1 $[, 7] *(37000) *(1600) *(4.5 e-005)$ \\ df1[, 17] <- df1[, 8] $\bullet(37000) *(1600) *(3.6 e-008+1.5 e-009)$ \\ df1 $[, 18]<-$ df1[, 9] * $(37000) \cdot(1600) \bullet(3.6 e-008+1.5 e-009)$ \\ dfl[, 19] <- df1[, 10] * (37000)*(1600)* $(3.6 \mathrm{e}-008+1.5 \mathrm{e}-009)$ \\ df1[, 20] <- df1[, 11] + df1[, 14] + df1[, 17] \\ df1[, 21] <- df1[, 12] + df1[, 15] + df1[, 18] \\ df1[, 22] <- dfl[, 13] + df1[, 16] + df1[, 19] \\ names(df1)[11:13] <- c("Cs.SvPL.M1", "Cs.SvPL.M2", "Cs.SvPL.M3") \\ namés(df1)[14:16] <-c("GA.SvPL.M1", "GA.SvPL.M2", "GA.SvPL.M3") \\ names(df1)[17:19] <- c("SrY.SvPL.M1", "SrY.SvPL.M2", "SrY.SvPL.M3") \\ names(df1)[20:22] <- c("ULD.M1", "ULD.M2", "ULD.M3") \\ ULD.SST.ICRP71.SLD.df < <- df1 \\ df2 $[, 11]<-d f 2[, 2] *(37000) *(1600) *(4.6 e-009)$ \\ df2[, 12] <- df2[, 3] * $(37000) *(1600) *(4.6 \mathrm{e}-009)$ \\ df2[, 13] <- df2[, 4] $\bullet(37000) *(1600) *(4.6 e-009)$ \\ df2[, 14] <- df2[, 5] * $(37000) *(1600) *(4.5 e-005)$ \\ df $2[, 15]<-d f 2[, 6] *(37000) *(1600) *(4.5 e-005)$ \\ df2 $[, 16]<-d f 2[, 7] *(37000) *(1600) *(4.5 e-005)$ \\ df2 $[, 17]<-d f 2[, 8] *(37000) *(1600) *(3.6 e-008+1.5 e-009)$ \\ df2 $[, 18]<-d f 2[, 9] *(37000) *(1600) *(3.6 e-008+1.50-009)$ \\ df2[, 19] <- df2[, 10] * (37000) $\bullet(1600) *(3.6 e-008+1.5 e-009)$ \\ $d f 2[, 20]<-d f 2[, 11]+d f 2[, 14]+d f 2[, 17]$ \\ $d f 2[, 21]<-d f 2[, 12]+d f 2[, 15]+d f 2[, 18]$ \\ $d f 2[, 22]<-d f 2[, 13]+d f 2[, 16]+d f 2[, 19]$ \\ names(df2)[11:13] <- c("Cs.SvPL.M1", "Cs.SvPL.M2", "Cs.SvPL.M3") \\ names(df2)[14:16] <- c("GA.SvPL.M1", "GA.SvPL.M2", "GA.SvPL.M3") \\ names(df2)[17:19] <- c("SrY.SvPL.M1", "SrY.SvPL.M2", "SrY.SvPL.M3") \\ names(df2)[20:22] <- c("ULD.M1", "ULD.M2", "ULD.M3") \\ ULD.DST.ICRP71.SLD.df $<<-$ df2 \\ \}
}

D2.0 THE S-PLUS FUNCTION LQD.ULD.FN

LQD.ULD.fn $=$

function(df1, df2)

\{

\#for LIQUID samples, df1 =SST.LQD.df, df2=DST.LQD.nu.AZ.df

df $1[, 11]<-\operatorname{df1}[, 2] \bullet(37000) *(6.7 e-009)$

df $1[, 12]<-d f 1[, 3] *(37000) *(6.7 e-009)$

D-3 


\section{HNF-4534 Rev. 1}

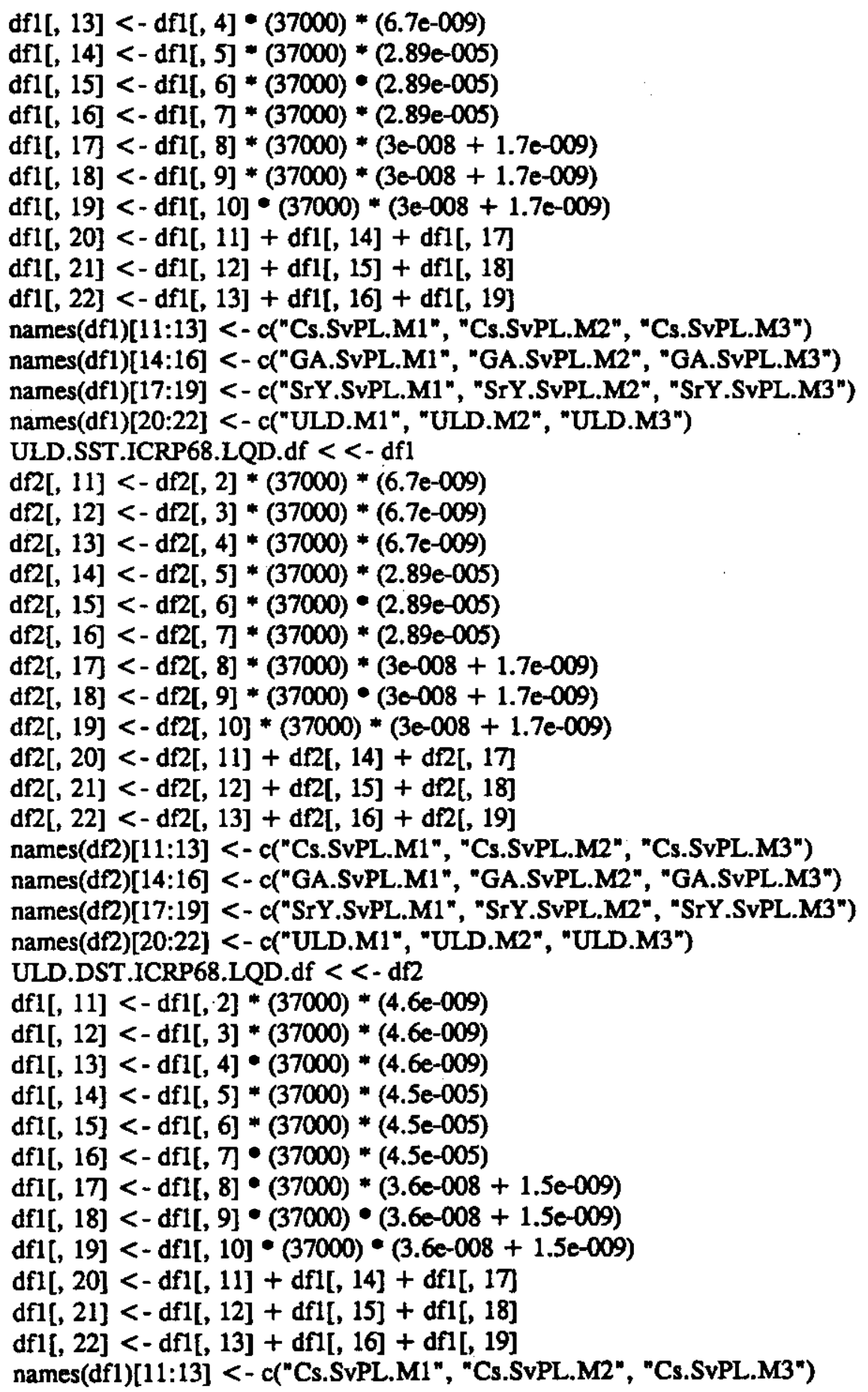

\section{D-4}




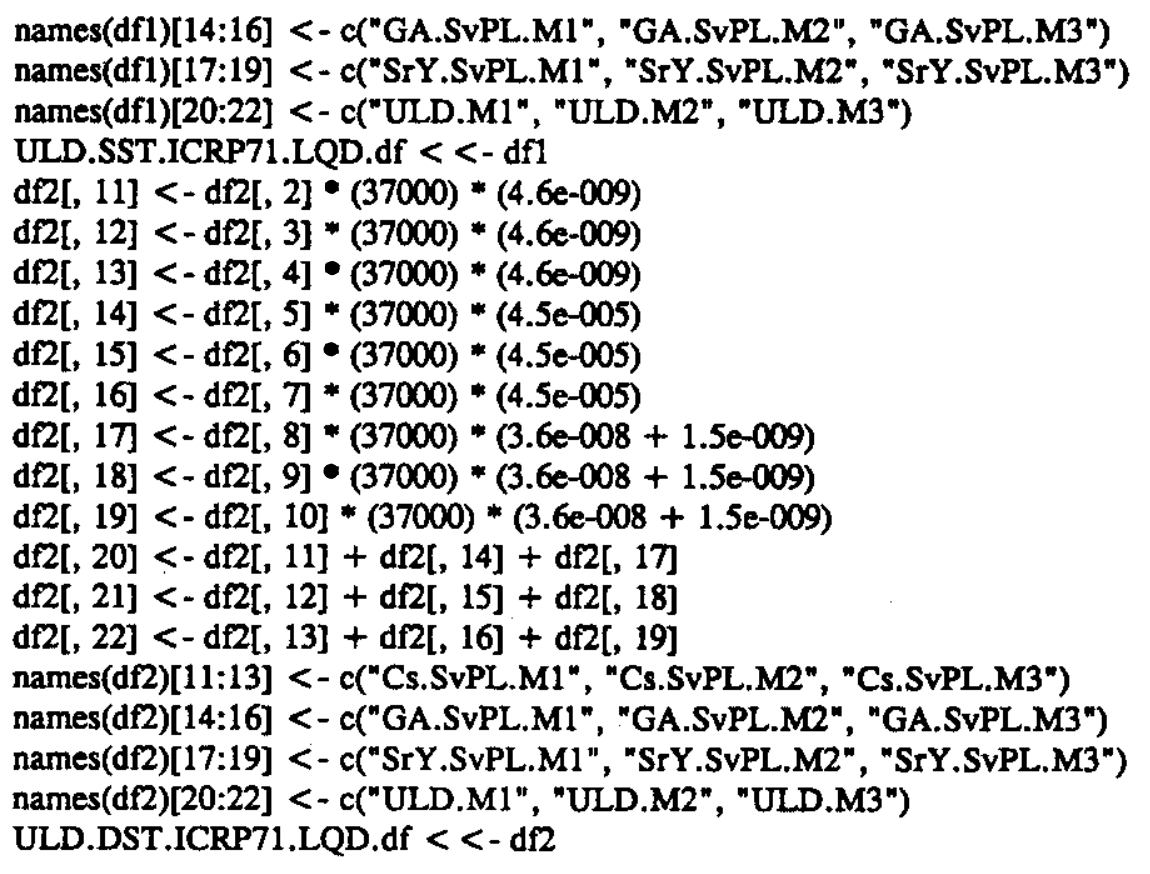

D-5 
RPP-5924 REV 0

HNF-4534 Rev. 1

This page intentionally left blank.

D-6 
RPP-5924 REV 0

HNF-4534 Rev. 1

APPENDIX E

\section{E.0 INDEPENDENT REVIEW}

E-1 
RPP-5924 REV 0

HNF-4534 Rev. 1

This page intentionally left blank.

E-2

C-66 
HNF-4534 Rev. 1

\section{REVIEW CHECKLIST}

Document Reviewed:
Jample Based Unit Liter Dose Estimater
by L. Jensen at S.R. W. Imarth HNF- 4534 Roul

Scope of Review:

Yes No NA

O $O$ - Previous reviews complete and cover analysis, up to scope of this review, with no gaps.

$\$ 0$ Problem completely defined.

O $\$$ Accident scenarios developed in a clear and logical manner.

Q 00 Necessary assumptions explicitly stated and supported.

D 0 Computer codes and data files documented.

Q 0 Data used in calculations explicitly stated in document.

Q $\bigcirc$ Data checked for consistency with original source information as applicable.

Q $O 0$ Mathematical derivation checked including dimensional consistency of results.

\$ 0 Models appropriate and used within range of validity or use outside range of established validity justified.

Q $0 \quad$ Hand calculations checked for errors. Spreadsheet results should be treated exactly the same as hand calculations.

Q $0 \quad$ Software input correct and consistent with document reviewed.

\$ 0 Sofware output consistent with input and with results reported in document reviewed.

$\bigcirc \quad 0 \quad$ Limits/criteria/guidelines applied to analysis results are appropriate and referenced.

Q $0 \quad 0 \quad$ Safety margins consistent with good engineering practices.

Q 00 Conclusions consistent with analytical results and applicable limits.

Q $O$ Results and conclusions address all points required in the problem statement.

$\bigcirc \otimes$ Format consistent with appropriate NRC Regulatory Guide or other standards.

O $\varnothing$ Review calculations, comments, and/or notes are attached.

Q 0 Document approved.

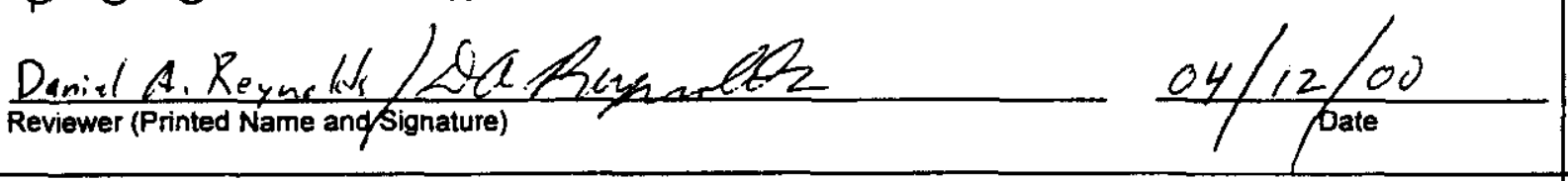

-Any calculations, comments, or notes generated as part of this review should be signed, dated and attached to this checklist. Such material should be labeled and reconded in such a manner as to be intelligible to a technically qualified third party. 
RPP-5924 REV 0

This page intentionally left blank.

C-68 
RPP-5924 REV 0

APPENDIX D

PEER REVIEW CHECKLIST

D-1 
RPP-5924 REV 0

This page intentionally left blank.

D-2 
RPP-5924 REV 0

Practice 1342901112

Publkeation Date 22Nov99

Attachmert 02 -Sheet 1 of 1

FLUOR DANIEL NORTHWEST

TECHNICAL PEIAR REVITWS

CHECKLIST FOR TECHNICAL PEER REVIEW

Document Reviewed: $R P P-5924, D \operatorname{roft} A$

Title:

Author: $w$. Cowley,

Date: $\quad 4 / 12 / \infty$

Scope of Review: Hrgh lewel review of logic, arguements, document

Yes No* NA

[ ] $]\left[x^{* *}\right.$

[S[ ] ] ]

[ ] [ ] $]$

[x][ ] ] ]

[][]$[\alpha]$

[x] ] [ ]

(4) ] [ ]

[ ] ] 14

Cal ] [ ]

flow, juotification of approach, ete.

[ ] $][x$

Previous reviews complete and cover analysis, up to scope of this review, with no gaps. Problem completely defined.

Accident scenarios developed in a clear and logical manner.

Necessary assumptions explicitly stated and supported.

Computer codes and data files documented.

Data used in calculations explicitly stated in document.

Data checked for consistency with original source information as applicable.

Mathematical derivations checked including dimensional consistency of results.

Models appropriate and used within range of validity, or use outside range of established validity justified.

[ ] $][x]$

[ ] $][x]$

Hand calculations checked for errors. Spreadsheet results should be treated exactly the same as hand calculations.

bi [ ] ]

Software input correct and consistent with document reviewed.

Software output consistent with input and with results reported in document reviewed.

Limits/criteria/guidelines applied to analysis results are appropriate and referenced.

Limits/criteria/guidelines checked against references.

TAS ] [ ]

by[ ] ]

Safety margins consistent with good engineering practices.

$B[][]$

[ ] $] 109$

[]

Conclusions consistent with analytical results and applicable limits.

Results and conclusions address all points required in the problem statement.

Format consistent with applicable guides or other standards.

Review calculations, comments, and/or notes are attached.

DA[ ] [ ] Document approved (for example, the reviewer affirms the technical accuracy of the document).

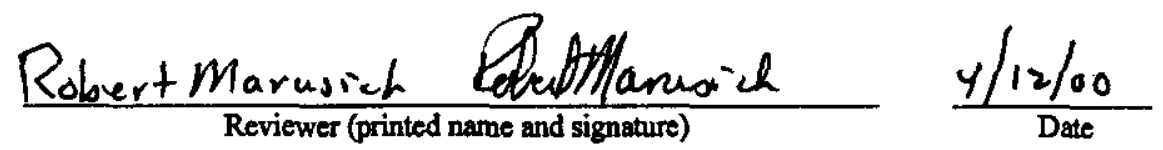

- All "no" responses must be explained below or on an additional sheet.

** Any calculations, comments, or notes generated as part of this review should be signed, dated, and attached to this checklist. The material should be labeled and recorded in such a manner as to be intelligible to a technically qualified third party. 


\section{CHECKLIST FOR TECHNICAL PEER REVIEW}

Document Reviewed:

Title: UpDateJ Dose Mrthads

Author: J.C. Ven Keareen

Date: $4 / 27 / 00$

Scope of Review: Attmahmonts 1 throm $h 8$

Yes Ne* NA

[ ] [ $][-]^{* *}$ Previous reviews complete and cover analysis, up to scope of this review, with no gaps.

b.] [ ] ] Problem completely defined.

$[$ ] [ ] Accident scenarios developed in a clear and logical manner.

$f][$ ] ] Necessary assumptions explicitly stated and supported.

(k] [ ] [ ] Computer codes and data files documented.

b.] [ ] [ ] Data used in calculations explicitly stated in document.

[X] [ ] [ ] Data checked for consistency with original source information as applicable.

[X] [ ] ] Mathematical derivations checked including dimensional consistency of results.

[X] [ ] [ ] Models appropriate and used within range of validity, or use outside range of established

$\triangle 4[][]$ validity justified.

[X] ] [ ] Software input correct and consistent with document reviewed.

[X] [ ] [ ] Software output consistent with input and with results reported in document reviewed.

[ ] [ ] [ ] Limits/criteria/guidelines applied to analysis results are appropriate and referenced.

[ ] [ ] L4. Safety margins consistent with good engineering practices.

[X] [ ] ] Conclusions consistent with analytical results and applicable limits.

[-4 [ ] [ ] Results and conclusions address all points required in the problem statement.

[Y] [ ] ] Format consistent with applicable guides or other standards.

[ ] []$^{* *}$ Review calculations, comments, and/or notes are attached.

[X][ ] [ ] Document approved (for example, the reviewer affirms the technical accuracy of the document).

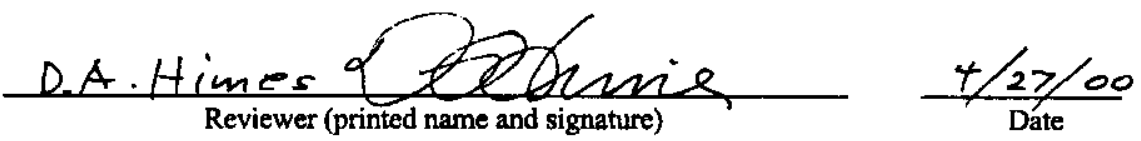

" All "no" responses must be explained below or on an additional sheet.

** Any calculations, comments, or notes generated as part of this review should be signed, dated, and attached to this checklist. The material should be labeled and recorded in such a manner as to be intelligible to a technically qualified third party. 


\section{DISTRIBUTION SHEET}

To

Distribution

Project Title/Work Order

RPP-5924 Radiological Source Terms for Tank Farms Safety Analysis

From

Safety Analysis
Name

CH2M Hill Hanford Group, Inc.

R. J. Cash

W. L. Cowley

J. M. Grigsby

L. E. Kripps

J. E. Meacham

$K$. R. Sandgren

Fluor Federal Services

J. C. Van Keuren

Lockheed Martin Services, Inc.

Central Files
Page 1 of 1

Date $6 / 19 / 2000$

EDT No. 629577

ECN No.

\begin{tabular}{|c|c|c|c|c|}
\hline MSIN & $\begin{array}{l}\text { Text } \\
\text { With All } \\
\text { Attach. }\end{array}$ & Text Only & $\begin{array}{l}\text { Attach.I } \\
\text { Appendix } \\
\text { Only }\end{array}$ & $\begin{array}{c}\text { EDT/ECh } \\
\text { Only }\end{array}$ \\
\hline
\end{tabular}

